Universidade de São Paulo

Instituto de Física

\title{
Fabricação de células solares de GaAs contendo pontos quânticos de InAs
}

\author{
Marcelo Delmondes de Lima
}

Orientador: Prof. Dr. Alain André Quivy

Dissertação de mestrado apresentada ao Instituto de Física como requisito parcial para a obtenção do título de Mestre em Ciências.

Banca Examinadora:

Prof. Dr. Alain André Quivy - Orientador (FUSP)

Prof. Dr. Ronaldo Domingues Mansano (EPUSP)

Prof. Dr. Daniel Neves Micha (CEFET-RJ) 


\section{Preparada pelo Serviço de Biblioteca e Informação do Instituto de Física da Universidade de São Paulo}

Lima, Marcelo Delmondes de

Fabricação de células solares de GaAs contendo pontos quânticos de InAs. São Paulo, 2019.

Dissertação (Mestrado) - Universidade de São Paulo. Instituto de Física. Depto. Física dos Materiais e Mecânica.

Orientador: Prof. Dr. Alain André Quivy

Área de Concentração: Física

Unitermos: 1. Células solares; 2. Junção PN; 3. Pontos quânticos; 4. Epitaxia por feixe molecular (MBE). 
São Paulo

2019

University of São Paulo

Physics Institute

\title{
Manufacture of GaAs solar cells containing InAs quantum dots
}

\author{
Marcelo Delmondes de Lima
}

Supervisor: Prof. Dr. Alain André Quivy

Dissertation submitted to the Physics Institute of the University of São Paulo in partial fulfillment of the requirements for the degree of Master of Science.

Examining Committee:

Prof. Dr. Alain André Quivy - Supervisor (IFUSP)

Prof. Dr. Ronaldo Domingues Mansano (EPUSP)

Prof. Dr. Daniel Neves Micha - (CEFET-RJ) 
São Paulo

2019

\section{Dedicatória}

Dedico esse trabalho à minha filhucha Alice Ribeiro de Lima, sem a qual a vida não teria a mesma graça. 


\section{Agradecimentos}

Agradeço à minha filha Alice por ser uma grande inspiração na minha vida e ter feito com que eu voltasse a ficar maravilhado com os aspectos simples da vida que a gente aprende a ignorar à medida que o tempo passa. Agradeço à minha mãe Zenilda, aos meus irmãos Caroline e Alex, pelo apoio emocional crucial para o desenvolvimento desse trabalho.

Agradeço ao professor Alain por ter tido tanta paciência comigo e ter me ajudado tanto com todos os tipos de problemas. É uma pessoa de virtudes excepcionais.

Agradeço à professora Euzi por ter me indicado para ser orientado por seu esposo e por tudo que me ensinou até hoje.

Agradeço aos professores Patrícia Lustoza de Souza, Maurício Pamplona Pires e Daniel Neves Micha por terem cedido os desenhos das máscaras das células solares.

Agradeço ao Dr. Carlos César Bof Bufon e ao Sr. Davi Henrique Starnini de Camargo pela fabricação das novas máscaras.

Agradeço ao professor Danilo Mustafa por ter permitido o acesso ao simulador solar.

Agradeço ao Geraldo, um dos grandes responsáveis por não deixar o laboratório parar, identificando os problemas e criando adaptações muito inteligentes.

Agradeço ao Sérgio que resolve nossos problemas de informática e que sempre nos dá um grande apoio nossos projetos. investimento.

Agradeço ao Tiago por suas ótimas dicas de como otimizar o tempo e sobre as dicas de

Agradeço ao Ahmad por ter me ajudado com os experimentos de PL, dentre tantas outras rotinas no laboratório.

Agradeço ao Thales por ter me ajudado tanto na correção dessa dissertação e por ter me feito repensar em alguns conceitos ou formas de abordagem.

Agradeço ao Leonardo por ter me ajudado a entender melhor o desenvolvimento do nosso experimento de responsividade espectral, por ajudar a fazer com que o perfilômetro funcionasse muito melhor do que antes e por me ensinar um pouco sobre como integrar as unidades computacionais que eu utilizava.

Agradeço ao Eduardo pelo engajamento e por ter me tirado algumas dúvidas sobre o experimento de responsividade espectral que, com certeza, utilizaremos nos próximos desenvolvimentos.

Agradeço ao Douglas por ter me ajudado a fazer os testes de TLM, a coletar dados com a "probe station" e a realizar as caracterizações com o simulador solar.

Agradeço à USP pelo apoio estudantil que me possibilitou continuar com esse trabalho.

O presente trabalho foi realizado com apoio da Coordenação de Aperfeiçoamento de Pessoal de Nível Superior - Brasil (CAPES) - Código de Financiamento 001. 


\section{Epígrafe}

Ó homens superiores, o pior que há em vós é: não aprendestes a dançar como se deves dançar - indo além de vós mesmos! Que importa se malograstes? Quanta coisa é ainda possível! Então aprendei a rir indo além de vós mesmos! Erguei vossos corações, ó bons dançarinos! Mais alto! E não esqueçais o riso tampouco!"

- Nietzsche, Assim Falou Zaratustra 


\section{Resumo}

Esse trabalho é o primeiro do Laboratório de Novos Materiais Semicondutores na área de células fotovoltaicas e, como tal, teve de enfrentar inicialmente vários desafios para que a pesquisa pudesse ser realizada em boas condições. Um panorama da tecnologia fotovoltaica atual foi apresentado, assim como todas as etapas da fabricação e dos testes dos dispositivos. As amostras foram crescidas pela técnica de epitaxia por feixes moleculares e processadas por litografia óptica, ataque químico molhado e metalização por feixe de elétrons. Usamos novas máscaras possuindo células solares com tamanho e contatos diferentes, e tentamos obter contatos elétricos de boa qualidade usando ligas diferentes para as camadas dopadas do tipo p e n. Após a fabricação de uma célula de GaAs de boa qualidade, usada como referência para o restante do estudo, algumas melhorias básicas foram feitas de maneira a aumentar a eficiência dela. Inicialmente, inserimos uma fina janela de $\mathrm{AlGaAs}$ na parte superior da estrutura para evitar a recombinação dos portadores na superfície, substituímos a camada traseira de GaAs mais dopada (BSF) por uma camada de AlGaAs para ver se isso melhorava o desempenho do dispositivo, e removemos da região óptica a fina camada superior de GaAs extremamente dopada (usada apenas para melhorar a qualidade do contato superior) para evitar que ela absorvesse parte da radiação incidente. A caracterização das células foi feita com um simulador solar e revelou que a primeira e terceira modificação melhoraram sensivelmente os dispositivos, levando a eficiência deles a $14 \%$, maior valor obtido nesse trabalho, sendo que a segunda modificação não surtiu efeito. Finalmente, uma célula solar baseada na melhor estrutura obtida e contendo pontos quânticos de InAs na região ativa foi processada de maneira a tentar aumentar ainda mais a eficiência pela absorção da radiação incidente possuindo uma energia abaixo do gap do GaAs e que normalmente não é aproveitada. Os resultados indicaram uma redução de eficiência da ordem de $40 \%$ com a introdução dos pontos quânticos na estrutura, provavelmente relacionada com a geração de defeitos estruturais durante a formação das nanoestruturas. Algumas soluções para esse problema consistem em aumentar a dopagem dos pontos quânticos e concentrar a presença deles na parte inferior da região ativa.

Palavras-chaves: Células solares; Junção PN; Pontos quânticos; Epitaxia por feixe molecular (MBE). 


\begin{abstract}
This is the first work of the Laboratory of New Semiconductor Materials in the field of photovoltaic cells and, as such, initially had to face several challenges so that the research could be carried out in good conditions. A panorama of the current photovoltaic technology is presented, as well as all the steps of the manufacture and tests of the devices. The samples were grown by molecular beam epitaxy and processed by optical lithography, wet etching and electron-beam metallization. We use new masks having solar cells with different sizes and contacts, and we tried to get good electrical contacts using different metallic alloys for the $\mathrm{p}$ and n-type regions. After the manufacture of a GaAs cell of good quality, that will be used as a reference for the remainder of the study, some basic improvements were made in order to increase its efficiency. Initially, we inserted a thin $\mathrm{AlGaAs}$ window at the top of the structure to prevent recombination of the carriers at the surface, then we replaced the back layer of highly doped GaAs material (BSF) by an AlGaAs layer to see if this improved the performance of the device, and, finally, we removed the thin top layer of extremely doped GaAs material (used only to improve the quality of the top contact) from the to prevent it from absorbing part of the incident radiation. The cell characterization was done with a solar simulator and revealed that the first and third modifications significantly improved the devices, leading an efficiency above $14 \%$, the highest value obtained in this work, and that the second modification did not have any relevant effect. Finally, a solar cell based on the best structure described above and containing InAs quantum dots in the active region was processed in order to try to further increase the efficiency by absorbing the incident radiation having an energy below the GaAs bandgap which is normally not harnessed. The experimental results indicated a reduction of efficiency of the order of $40 \%$ after the introduction of the quantum dots in the structure, an effect that is probably related to the generation of structural defects during the formation of nanostructures. Some solutions to this problem are to increase the doping of the quantum dots and to concentrate their presence in the lower part of the active region.
\end{abstract}

Keywords: Solar cells; PN junction; Quantum dots; Molecular beam epitaxy (MBE). 


\section{Lista de figuras}

Figura 1: Irradiância (potência luminosa de origem solar por metro quadrado) média anual no nível do mar. Os discos pretos representam a área a ser coberta por módulos fotovoltaicos para satisfazer o consumo energético mundial a partir da energia solar. As cores mostram uma média de três anos, incluindo noites e cobertura de nuvens [10].

Figura 2: Demanda mundial de energia em 2016 [12].

Figura 3: Consumo total de energia elétrica em 2016. O consumo de energia elétrica no mundo em 2016 seria suprido pela geração de aproximadamente 2,638 TW [13].

Figura 4: Empregos gerados no mundo pela tecnologia da energia renovável em 2017, com a liderança da energia solar fotovoltaica. Fonte: Irena. Infográfico elaborado em: 24/09/2018. 20 Figura 5: Capacidade mundial de geração de energia por sistemas fotovoltaicos e adições ocorridas entre 2007 e 2017 [2].

Figura 6: Capacidade mundial de geração de energia por sistemas fotovoltaicos por país ou região entre 2007 e 2017 [4]. 21

Figura 7: Capacidade mundial de geração de energia por sistemas fotovoltaicos e adições ocorridas nos países que mais geraram em 2017 [4]

Figura 8: Adições na capacidade mundial de geração de energia por sistemas fotovoltaicos, nos 10 países que mais geraram e no resto do mundo, em 2017 [4].

Figura 9: Evolução da eficiência de conversão de vários tipos de células solares em função do tempo. À direita temos a eficiência máxima obtida até agora para cada tecnologia [19].

Figura 10: Esquema do satélite Vanguard I. Por causa do seu diâmetro de $16 \mathrm{~cm}$, também foi chamado "Grapefruit" (foto: NASA) [30].

Figura 11: Sistema solar moderno da sonda espacial Dawn com potência de 5 kW [32].

Figura 12: Diagrama de nível de energia para uma superfície de GaAs. Energias híbridas de gálio e arsênico $\left(\varepsilon_{\mathrm{h}}^{\mathrm{Ga}}, \varepsilon_{\mathrm{h}}^{\mathrm{As}}\right)$ não ligado (ligação pendente), bem como energias de ligação $\mathrm{Ga}-\mathrm{Ga}\left(\varepsilon_{\mathrm{b}}^{\mathrm{GaGa}}\right), A s-A s\left(\varepsilon_{\mathrm{b}}^{\mathrm{AsAs}}\right)$ e Ga-As ( $\left.\varepsilon_{\mathrm{b}}^{\mathrm{GaAs}}\right)$ são mostradas [36]

Figura 13: Banda de valência, banda de condução e o gap $\mathrm{E}_{\mathrm{G}}$. _ 31

Figura 14: Representação das bandas de energia de isolantes, semicondutores e metais [37]. ___ 31

Figura 15: Relação da dopagem com a energia de Fermi $E_{F}$ em materiais onde são adicionados átomos de dopantes para se aumentar o número de elétrons, representados pelas bolas vermelhas (material tipo N), e em materiais onde há adição de átomos para que se crie buracos (também chamados de lacunas), representados pelas bolas brancas, (material tipo $P$ ) [38].

Figura 16: Eletrostática da região de depleção da junção $P N$ mostrando a) as regiões dopadas e de depleção, b) a distribuição de cargas fixas, c) o valor do campo elétrico interno e d) o valor da tensão interna $V_{b i}$ [39]. 34

Figura 17: Diagrama de bandas da junção PN em equilíbrio. $\mathrm{E}_{\mathrm{F}}$ é o nível de Fermi na interface da junção e deve ser constante na estrutura inteira; Ei é o nível de Fermi de cada material antes de ser formada a junção; $\mathrm{E}_{\mathrm{V}}$ é o nível máximo da banda de valência e $\mathrm{E}_{\mathrm{C}}$ é o nível mínimo da banda de condução. Figura 18: Circuito completo de um diodo a) sem polarização e b) com polarização direta [39]. ___ 39 Figura 19: Representação dos níveis de energia de uma junção $P N$ em equilíbrio com a representação dos portadores de carga majoritários e minoritários. Os símbolos dão uma ideia da distribuição dos elétrons (bolinhas) e dos buracos (círculos) no níveis de energia [39]. 41 Figura 20: Diagrama de bandas da junção PN sob polarização direta. b) Componentes de corrente que atravessam a ZD quando a junção está sob polarização direta $\left(\mathrm{V}_{\mathrm{A}}>0\right)$ [39].___ 42 Figura 21: Fluxo de portadores em um circuito com a junção $P N$ sob polarização direta $\left(\mathrm{V}_{\mathrm{A}}>0\right)$ [39]. 42 Figura 22: Diagrama de bandas da junção PN sob polarização reversa. b) Componentes de corrente que atravessam a ZD quando a junção está sob polarização reversa $\left(\mathrm{V}_{\mathrm{A}}<0\right)$ [39].

Figura 23: Fluxo de portadores em um circuito com a junção $P N$ sob polarização reversa $\left(\mathrm{V}_{\mathrm{A}}<0\right)$ [39].44

Figura 24: Curva IxV de uma célula solar [41]. 
Figura 27: Esquema de uma célula solar real iluminada onde constam a corrente fotogerada $\mathrm{I}_{\mathrm{Ph}}$, a corrente de diodo no escuro $\mathrm{I}_{\mathrm{D}}$, a corrente de fuga (shunt) $\mathrm{I}_{\mathrm{sh}}$, a corrente fornecida ao circuito externo $\mathrm{I}$, as resistências de shunt $\mathrm{R}_{\mathrm{sh}}$ e de série $\mathrm{R}_{\mathrm{S}}$ e a queda de tensão $\mathrm{V}$ medida nos contatos elétricos da célula. 48 Figura 28: Dependência do fator de idealidade $n$ do modelo de um diodo com a voltagem gerada na junção pela luz numa célula solar típica de Si. Para o caso real, usamos $R_{s}=0,100 \Omega . \mathrm{cm}^{2}, R_{\text {sh }}=1,00 \mathrm{M} . \mathrm{cm}^{2}, I_{0}=$ $1,00 \times 10^{-13} \mathrm{~A} / \mathrm{cm}^{2}[44]$. 50

Figura 29: Curva característica de uma célula solar iluminada com os principais parâmetros [50]. _ 50 Figura 30: Diagrama de bandas de energia para o metal, à esquerda, e para um semicondutor dopado do tipo $N$, à direita, no momento do contato e logo antes do estabelecimento do equilíbrio. $\mathrm{E}_{0}$ é o nível de energia do vácuo, no qual o elétron está livre fora do material. $\Phi_{\mathrm{M}}$ é a função trabalho do metal. No semicondutor, $\Phi_{\mathrm{S}}$ é a função trabalho; $\mathrm{E}_{\mathrm{C}}$ é o mínimo da banda de condução; $\mathrm{E}_{\mathrm{V}}$ é o máximo da banda de valência; $\mathrm{E}_{\mathrm{FS}}$ é o nível de Fermi para o semicondutor dopado; $X$ é a afinidade eletrônica do semicondutor [39].

Figura 31: Curvatura das bandas do semicondutor na interface como metal e formação da Barreira Schottky de altura $\Phi_{\mathrm{B}}$ na junção MS-N [39].

Figura 32: Distribuição de energia do espectro solar. 0 eixo vertical se relaciona com a quantidade de fótons correspondente a cada comprimento de onda [58].

Figura 33: Irradiância solar fora da atmosfera terrestre $(A \overline{M O})$, sobre a face da terra com incidência direta no zênite (AM1), com incidência direta de $48.2^{\circ}$ (AM 1.5D) ou considerando também a contribuição do espalhamento atmosférico - linha tracejada - (AM 1.5G), que é o padrão geralmente usado [61]. __ 56 Figura 34: Irradiâncias espectrais de acordo com a norma ASTM G173-03 e os gaps dos principais materiais utilizados na tecnologia fotovoltaica [59] [64] [66].

Figura 35: Espectro de irradiação solar padrão AM1.5G, correspondente à intensidade de 1 sol. A fração de energia desse espectro que é absorvida por um material de $\mathrm{E}_{\mathrm{G}}=1,4 \mathrm{eV}$ é mostrada em rosa e foi obtida segundo o cálculo desenvolvido por Shockley e Queisser. A eficiência de conversão de energia calculada é de 31,3\% [68]. 58 Figura 36: Máximas eficiências de conversão possíveis, derivadas do balanço detalhado para uma variedade de estratégias avançadas que fazem parte da terceira geração. O cálculo original de SchockleyQueisser para uma célula solar de junção única tradicional também é mostrado, bem como alguns recordes certificados (até novembro de 2012). Os pequenos traços pretos horizontais correspondem às eficiências recordes. [67]. Figura 37: (esquerda) Imagem de TEM, em seção transversa, de um ponto quântico de InAs depositado em nosso grupo sobre uma superfície de GaAs nas mesmas condições que aquelas usadas neste trabalho. (direita) Imagem de AFM mostrando os QDs de InAs da mesma amostra. 60 Figura 38: Distribuição de carga nos QDs e diagramas que descrevem as vias de relaxação de elétrons em CS-QDSKs de InAs/GaAs, onde $E_{0}$ e $E_{1}$ são o estado fundamental e o primeiro estado excitado, respectivamente [73].

Figura 39: Estrutura PIN básica das CSs produzidas para esse trabalho. _ـ 63 Figura 40: Crescimento epitaxial. Os átomos ou moléculas do feixe incidente se ajustam ao parâmetro de rede do substrato [56].

Figura 41: Estrutura da célula de referência, CS-GaAs. __ 64

Figura 42: Estrutura da célula com janela, CS-FSF.__ 65

Figura 43: Estrutura da célula de referência, CS-GaAs. _ 65

Figura 44: Estrutura da célula com janela e BSF de AlGaAs, CS-F\&BSF. _ 65

Figura 45: Estrutura da célula com janela, CS-FSF.__ 65

Figura 46: Estrutura da célula com pontos quânticos CS-QDSK. ___ 66

Figura 47: Estrutura da célula com janela, CS-FSF.__ 66

Figura 48: Esquema de um sistema MBE __ 67

Figura 49: Sistema MBE do LNMS-USP, modelo Mod Gen 2 da empresa Varian.___ 67

Figura 50: Carrinho para o deslocamento das amostras entre a CES e a CB. __ 68

Figura 51: Método de crescimento de QDs de Stranski-Krastanov [78]. __ 69

Figura 52: Princípio de fotolitografia positiva e negativa mostrando como a máscara e o fotorresiste podem ser utilizados para construir padrões na superfície das amostras [80]. __ 70 Figura 53: Spinner fechado e pronto para o funcionamento, com a amostra posicionada no centro. __ 71 Figura 54: Placa aquecedora ("hot plate") com a amostra 3800 a $90^{\circ} \mathrm{C}$, durante o "soft baking". _ 72 
Figura 55: Fotoalinhadora. No monitor, acima da fotoalinhadora, visualizamos o padrão da máscara captado pelo sistema óptico.__ 72 Figura 56: Máscara fixada na Fotoalinhadora. Figura 57: Região da primeira máscara evidenciando alguns "fingers" e a "busbar" de 4 células. Na máscara, apenas as regiões pretas são metalizadas, e a litografia será negativa. A imagem foi obtida pelo software LayoutEditor. 73

Figura 58: Região da máscara evidenciando algumas mesas. Na máscara, apenas as regiões verdes são metalizadas, e a litografia será positiva. A imagem foi obtida pelo software LayoutEditor. __ 73 Figura 59: Região da máscara evidenciando a superfície com os contatos superiores e inferiores que devem ser protegidos durante a remoção do "cap layer" dopado. Na máscara, apenas as regiões cinzas são metalizadas, e a litografia será positiva. A imagem foi obtida pelo software LayoutEditor. __ 74 Figura 60: Exemplo de amostra após o procedimento de revelação positiva. Os quadrados maiores possuem $150 \mu \mathrm{m}$ de lado. _ 74

Figura 61: Perfilômetro. A amostra a ser medida está localizada abaixo da ponta de prova. __ 75 Figura 62: Perfil típico obtido pelo perfilômetro, de um padrão de fotorresiste para definir a "bussbar"e os fingers". 75 Figura 63: Quadrante utilizado de uma das máscaras ${ }^{11}$. Existe uma grande variedade de tamanho de mesa (2, 3 e $5 \mathrm{~mm})$ e de número de "fingers (2, 5, 8 e 10)". 76 Figura 64: Amostra totalmente processada vista pelo sistema óptico do simulador solar com várias mesas. Cada mesa retangular preta é uma célula solar. 76 Figura 65: O sistema de deposição por feixe de elétrons, modelo Nexdep da empresa Angstrom Engineering. 79 Figura 66: Parte interna da metalizadora, mostrando 1) o porta-amostras, 2) o medidor de espessura, 3) o obturador principal e 4) o carrossel atrás de um anteparo. _ 80 Figura 67: Amostras fixadas no suporte da metalizadora. Figura 68: Amostra mergulhada em acetona durante o "lift off". 81 Figura 69: Lift off sendo terminado, eventualmente com cotonete, sem deixar a acetona secar.___ 81 Figura 70: Amostra processada e fixada para medidas de EQE. ___ 81 Figura 71: Exemplo de uma receita armazenada. Em cada linha são configurados os parâmetros de cada passo como tempo, temperatura e fluxo de gases. ___ 82 Figura 72: Sistema de recozimento rápido (RTA).____ 82 Figura 73: Imagem de uma Amostra de GaAs que recebeu as camadas de $\mathrm{Ni}$, Ge e Au, antes do recozimento térmico (RTA). _ 83 Figura 74: Estrutura do mesmo filme metálico após o recozimento térmico.___ 83 Figura 75: Gráfico fornecido pelo computador do processo de recozimento térmico (RTA). A curva verde fina representa a rotina de temperatura planejada. A curva azul fina corresponde à temperatura real durante o recozimento. A curva verde grossa corresponde ao fluxo de $N_{2}$. A curva vermelha corresponde $\grave{a}$ potência aplicada nas lâmpadas para fornecer o perfil de temperatura desejado. 84 Figura 76: "Probe station" modelo EP6 da empresa Cascade Microtetech, correspondente ao modelo EPS150 Triax da empresa Form Factor.

Figura 77:Detalhe das pontas de prova da "probe station" tocando uma amostra. A intensidade da iluminação sobre a amostra pode ser ajustada. 85 Figura 78: CS obtida com a utilização da máscara utilizada para fabricar fotodetectores. Detalhe das posições das duas pontas de prova para testar uma mesa (quadrado preto). Uma ponta de prova encosta no contato superior que está sobre a mesa e a outra encosta no contato inferior comum a todas as mesas.

Figura 79: "Probe station" totalmente isolada afim de se evitar o efeito da luz ambiente e de ruídos elétricos externos. À direita, pode-se observar o analisador de parâmetros semicondutores. 86 Figura 80: Curva IXV entre 2 contatos isolados do tipo $N$, antes do recozimento térmico, apresentando comportamento não ôhmico.

Figura 81: Curva I $\times$ V entre 2 contatos isolados do tipo $N$, depois do recozimento térmico, apresentando comportamento ôhmico. 87 Figura 82: Amostra processada, com padrão TLM, para teste de resistividade, sendo medida com 4 pontas de prova numa "probe station". 
Figura 84: A curva da resistência total medida $R_{T}$ em função da distância entre dois contatos vizinhos do padrão TLM nos proporciona o valor da resistência de cada contato Rc e o valor da resistência de folha RsH da amostra.

Figura 85: Relação entre o fluxo de corrente, o comprimento LTLM e a resistividade $\rho_{\text {c }}$ do contato. __ 89 Figura 86: Diagrama dos componentes do sistema AFM [99]. No caso específico dessa figura, o "cantilever" é fixo e é a amostra que é deslocada pelo sistema piezelétrico. 90 Figura 87: Processo de excitação e emissão num experimento de fotoluminescência [99]. Caso haja impurezas não intencionais ou dopagem (intencional) no material semicondutor, haverá, além do gap, também níveis de energia relacionados com essas impurezas doadoras (tipo n) ou aceitadoras (tipo p). 91 Figura 88: Esquema de um arranjo experimental de fotoluminescência [99].

Figura 89: Arranjo experimental do experimento de absorção. 1 - Monocromador; 2 - Fonte de radiação infravermelha ("globar") que em nosso caso foi substituída por uma lâmpada halógena que possui um espectro mais intenso no visível; 3 - Roda de Filtros; 4 - Sensor de silício; 5 - "Chopper"; 6 - "Lock-in"; 7 Computador [102].

Figura 90: Célula solar num "chip carrier" para medidas de absorção a $300 \mathrm{~K}$ ___ 93

Figura 91: Simulador solar utilizado nesse trabalho. __ 94

Figura 92: Sistema óptico do simulador solar usado para posicionar as duas agulhas sobre os contatos dos dispositivos

Figura 93: Apresentação esquemática da parte interna do Simulador Solar da Abet Technologies [104].95

Figura 94: Exemplo de resultados fornecidos de maneira automática pelo simulador solar. __ 95

Figura 95: Curva IxV de uma CS no escuro, mostrando (em baixo à direita) os valores do fator de idealidade (n) e da corrente reversa (Io). 96

Figura 96: Medidas de TLM para o contato tipo N formado pela liga Ni/Ge/Au. __ 97 Figura 97: Medidas de TLM para o contato tipo $P$, sobre a amostra CS-FSF. _—_ 98 Figura 98: Curva IxV obtida com o simulador solar da CS de GaAs fabricada com a máscara dos fotodetectores e usando a liga Ni/Ge/Au para os dois tipos de contato. Podemos ver que a resistência em série (provavelmente dos contatos) é muito alta, e a eficiência muito baixa (1,78\%). __ 99 Figura 99: Curva IV obtida com o simulador solar para a CS-GaAs, fabricada com as novas máscaras da PUC-Rio, usando a liga Ni/Ge/Au para o contato $\mathrm{N}$ e a liga Ti/Pt/Au para o contato P. A resistência em série ficou muito menor e a curva em geral possui a forma habitual, levando a uma eficiência de 10,81\%.

Figura 100: Relação entre a eficiência da amostra CS-GaAs (plotada no eixo horizontal) e a área total iluminada Ai (plotada no eixo esquerdo), assim como o número de "fingers" N (plotado no eixo direito). São plotados apenas os valores de máxima eficiência para cada tipo de mesa. 100 Figura 101: Relação entre a eficiência da amostra CS-FSF (plotada no eixo horizontal) e a área total iluminada Ai (plotada no eixo esquerdo), assim como o número de "fingers" N (plotado no eixo direito). São plotados apenas os valores de máxima eficiência para cada tipo de mesa. 101 Figura 102: Comparação entre as eficiências das mesas da CS-FSF à esquerda e da CS-GaAs à direita. 102 Figura 103: Relação entre a eficiência da amostra CS-F\&BSF (plotada no eixo horizontal) e a área total iluminada Ai (plotada no eixo esquerdo), assim como o número de "fingers" N (plotado no eixo direito). São plotados apenas os valores de máxima eficiência para cada tipo de mesa. 102 Figura 104: Comparação entre as eficiências das mesas da CS-F\&BSF à esquerda e da CS-FSF à direita. 103

Figura 105: Relação entre a eficiência da amostra CS-QDSKs BSF (plotada no eixo horizontal) e a área total iluminada $\mathrm{A}_{\mathrm{i}}$ (plotada no eixo esquerdo), assim como o número de "fingers" $N$ (plotado no eixo direito). São plotados apenas os valores de máxima eficiência para cada tipo de mesa. 104 Figura 106: Comparação entre as eficiências das mesas da CS-FSF à esquerda e da CS-QDSK à direita. 104 Figura 107: Espectro de PL da estrutura das 4 células solares a $77 \mathrm{~K}$. __ 105 Figura 108: Gráfico da EQE das amostras CS-QDSK e CS-FSF. _ 107 Figura 109: Gráfico do fator de idealidade versus a eficiência das amostras CS-FSF e CS-QDSK.__ 107 Figura 110: Gráfico do fator do log $\left\{J_{0}\left[\mathrm{~A} / \mathrm{cm}^{2}\right]\right\}$ versus a eficiência das amostras CS-FSF e CS-QDSK. _ 107 Figura 111: Efeito da remoção da cap layer nos valores de eficiência da amostra CS-FSF. As barras laranjas são sos valores de eficiência das mesas antes da remoção do Cap Layer. As barras azuis são as eficiências obtidas após a remoção do Cap Layer. A barra cinza é o ganho de eficiência. 107 
Figura 112: Comparação dos valores máximos de eficiência obtidos nas medições das mesas B03 a B08 de cada amostra.

Figura 113: Curvas IxV de CSs com a mesma área superficial e o mesmo design de fingers, portanto, mesma área iluminada.

Figura 114: Localização das cidades de Cuiabá e Porto Alegre. Fonte: Google Maps.

Figura 115: Irradiância espectral direta normal típica para uma massa de ar unitária em Albuquerque, NM; Porto Alegre, RS e Cuiabá, MT [113].

Figura 116: Espectro característico para uma superfície voltada para o norte e com inclinação de $3^{\circ}$ na cidade de Manaus, AM (vermelho) e o espectro definido pela norma ASTM G-173 (azul) [113]. Figura 117: Quadrante utilizado da máscara [55] no processamento de todas as amostras. 


\section{Lista de Tabelas}

Tabela 1: Eficiência de uma célula solar de junção pn única de GaAs a $25{ }^{\circ} \mathrm{C}$ calculada com o modelo de Shockley-Queisser, supondo uma irradiância espectral AM 1.5G (ASTM G173-03) e uma emissão radiativa tanto do lado frontal como da face oposta à incidência da luz [4]. Eg é o gap do GaAs com o comprimento de onda correspondente $\lambda_{g} ; J_{\max }$ a densidade máxima de fotocorrente; $J_{s c}$ a densidade de corrente de curto circuito; $J_{m p p}$ a densidade de corrente no ponto de potência máxima; $V_{o c}$ a voltagem de circuito aberto; $V_{\text {mpp }}$ a voltagem no ponto de potência máxima; FF o fator de preenchimento e $\eta$ a eficiência [65] . ------ 59 Tabela 2: Valores calculados a partir do gráfico mostrado na Figura 96. ---------------------------------- 97 Tabela 3: Valores calculados para a amostra CS-FSF a partir do gráfico mostrado na Figura 97. --------- 98 Tabela 4: Tabela resumindo as informações dos gráficos 37 a 41. As medidas de TLM para o contato tipo $\mathrm{N}$, com a utilização da liga $\mathrm{Ni} / \mathrm{Ge} / \mathrm{Au}$ com espessura de 25/55/150 nm, respectivamente, submetida ao RTA de $520^{\circ} \mathrm{C}$, por $30 \mathrm{~s}$. TLM para o contato tipo P, com a utilização de Pt/Ti/Au com espessura de 20, 100 e $200 \mathrm{~nm}$ respectivamente. ----

Tabela 5: Dados da amostra de referência CS-GaAs obtidos com auxílio do simulador solar. ---------- 100

Tabela 6: Dados da amostra CS-FSF obtidos com auxílio do simulador solar. ----------------------------- 101

Tabela 7: Dados da amostra CS-F\&BSF obtidos com auxilio do simulador solar. ---------- 102

Tabela 8: Dados da amostra CS-QDSK obtidos com auxílio do simulador solar. ----------------104

Tabela 9: Comparação entre mesas com as mesma geometrias de contatos e com as mesmas áreas iluminadas.-------------------------------------------------------------------------------------------------------------------- 107

Tabela 10: Detalhes das áreas das mesas e dos contatos da máscara mostrada na Figura 117. --------- 124 


\section{Nomenclatura e significado nesse trabalho}

$\AA$

AR

ARC

BS

BS-N

BS-P

c

CS

CS-GaAs

CS-QDSK

e

$E_{G}$

FP

$\mathrm{h}$

hc

$I_{0}$

$I_{C C}$

$I_{L}$

$I_{M P}$

IVP

$\mathrm{k}$

LV

Angstron, $1 \AA=10^{-10} \mathrm{~m}=10^{-8} \mathrm{~cm}=10^{-7} \mathrm{~mm}=10^{-4} \mu \mathrm{m}=10^{-1} \mathrm{~nm}$.

Antirreflexivo, do inglês "anti reflective".

Camada antirreflexiva, do inglês "anti reflective coating".

Barreira Schottky.

Barreira Schottky em uma interface MS-N.

Barreira Schottky em uma interface MS-P.

Velocidade da luz, $c=299792458 \cdot \mathrm{m} \cdot \mathrm{s}^{-1}$.

Célula solar, célula fotovoltaica ou fotocélula.

Célula solar contendo apenas camadas de GaAs, utilizada como referência para comparação com as outras células fabricadas.

Célula solar com pontos quânticos crescidos no regime Stranski-Krastanov.

Carga do elétron, $e=1,60217662 \cdot 10^{-19} \mathrm{C}$.

Energia do gap do material.

Fator de preenchimento.

Constante de Planck, $h=6,626070040 \cdot 10^{-34} \mathrm{~J} \cdot s$.

Produto da constante de Planck pela velocidade da luz [1].

$$
h c=1,2398419739(76) \mathrm{eV} \cdot \mu \mathrm{m}
$$

Corrente de saturação reversa de uma junção PN.

Corrente de curto circuito (equivalente a $\mathrm{I}_{\mathrm{sc}} \mathrm{em}$ inglês).

Corrente fotogerada numa CS.

Corrente correspondente à máxima potência fornecida pela CS.

Infravermelho próximo.

Constante de Boltzmann, $k=1,38064852 \cdot 10^{-23} \mathrm{~J} \cdot K^{-1}$.

Luz visível.

LNMS/IFUSP Laboratório de Novos Materiais Semicondutores do Instituto de Física da USP.

$m_{e} \quad$ Massa do elétron livre.

$m_{e}^{*} \quad$ Massa efetiva de um elétron dentro de um sólido.

$m_{h}^{*} \quad$ Massa efetiva de um buraco dentro de um sólido.

MBE Epitaxia por feixes moleculares, do inglês "molecular beam epitaxy".

MC Monocamada ou ML, do inglês "monolayer".

MS Interface metal-semicondutor.

MS-N Interface metal-semicondutor, considerando que o semicondutor é um material dopado do tipo $\mathrm{N}$ para que o seu número de elétrons seja aumentado.

MS-P Interface metal-semicondutor, considerando que o semicondutor é um material dopado do tipo P para que o seu número de buracos (ou buracos) seja aumentado.

n Fator de idealidade de uma junção PN.

$P_{M a ́ x} \quad$ Potência máxima fornecida por uma célula solar.

PIN Junção formada por uma camada de material não dopado I (intrínseco) entre uma camada de material dopado do tipo P e outra camada de material dopado do tipo N.

PN Junção formada por uma camada de material dopado tipo P e outra camada de material dopado tipo $\mathrm{N}$.

QDs Pontos quânticos, do inglês "quantum dots".

QDSK Pontos quânticos produzidos no regime Stranski-Krastanov.

$R_{S} \quad$ Resistência em série de uma célula solar.

$R_{S h} \quad$ Resistência de shunt, correspondente à corrente de fuga da CS. 
RHEED Técnica de difração e reflexão de elétrons de alta energia, do inglês "reflection high energy electron diffraction".

RTA Recozimento térmico rápido, do inglês "rapid thermal annealing".

SK Stranski-Krastanov.

UV Ultra violeta.

$V_{O C} \quad$ Voltagem de circuito aberto, do inglês "open-circuit voltage".

$V_{M P} \quad$ Voltagem correspondente à máxima potência fornecida pela CS.

ZCE Zona de carga espacial.

ZD Zona de depleção.

$\lambda \quad$ Comprimento de onda.

Letra grega "Eta” , simboliza o rendimento (eficiência) de uma célula solar. 


\section{Sumário}

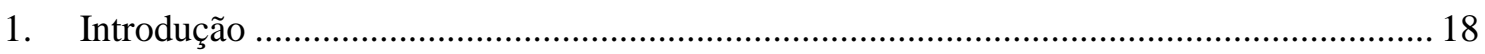

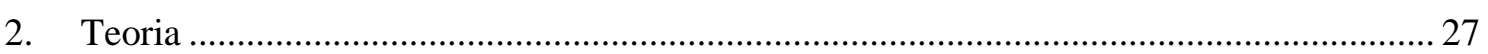

2.1. História do efeito e da tecnologia fotovoltaicos ....................................................... 27

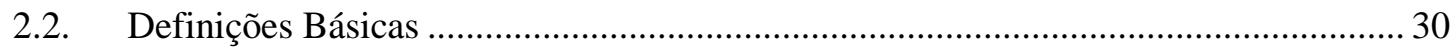

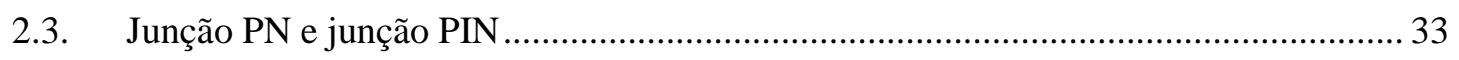

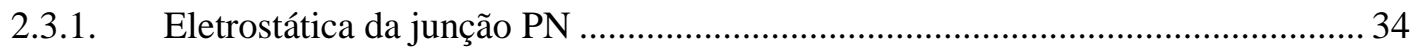

2.3.2. Diagrama de bandas da junção PN ………….................................................... 35

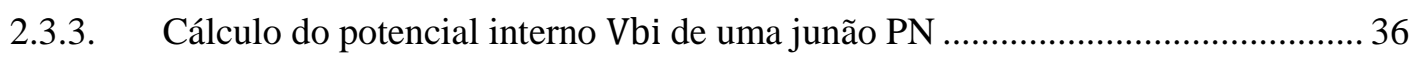

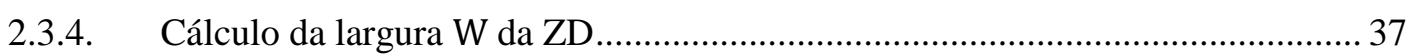

2.3.5. Aplicação de polarização à junção PN ................................................................. 38

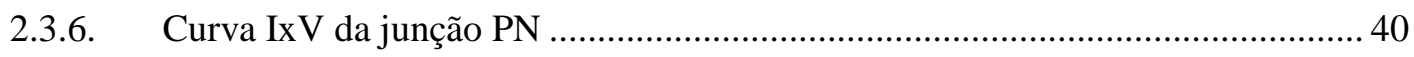

I. Análise qualitativa da curva IxV da junção PN...................................................... 40

i. Em equilíbrio, ou seja, na ausência da polarização .............................................. 40

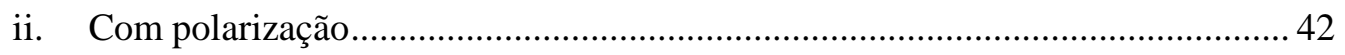

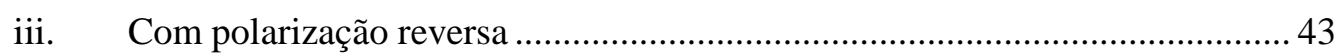

II. Análise quantitativa da curva I×V de uma CS de junção PN.............................. 44

III. Adaptações ao caso real .................................................................................. 47

IV. Simplificações e interpretações da curva $\mathrm{IxV}$.................................................... 48

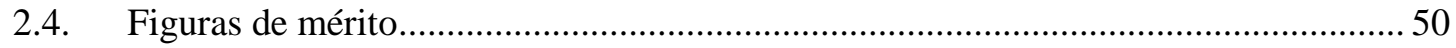

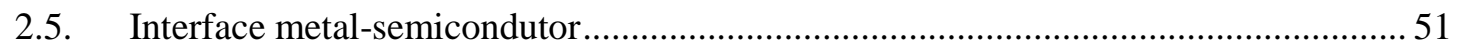

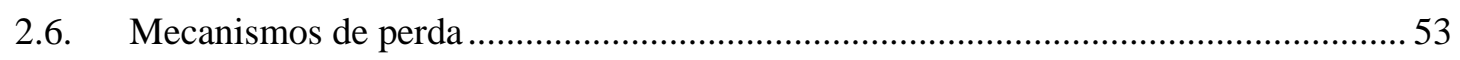

2.7. Radiação solar e espectro solar padrão..................................................................... 54

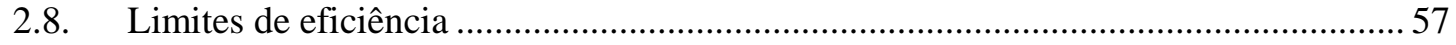

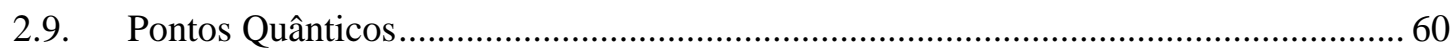

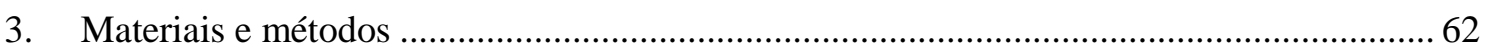

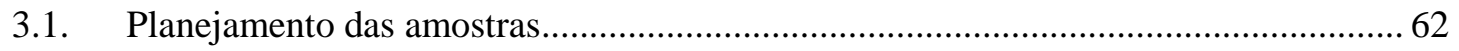

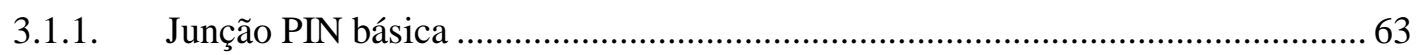

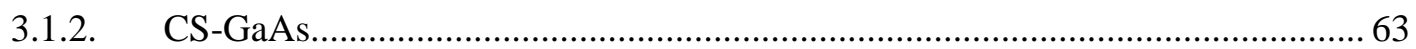

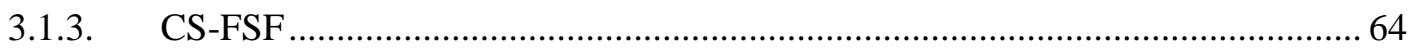

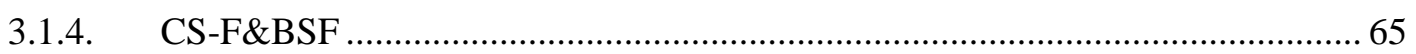

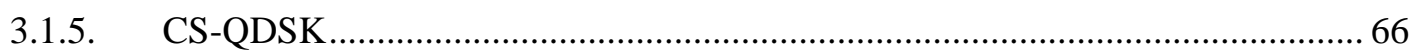

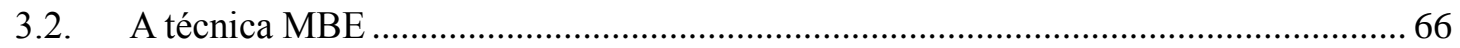

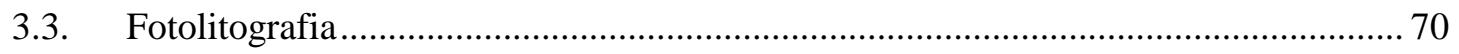

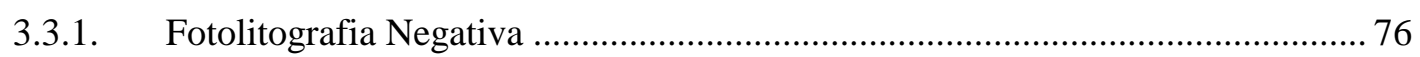

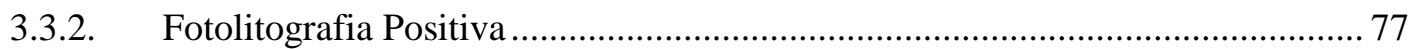

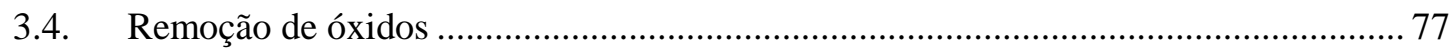




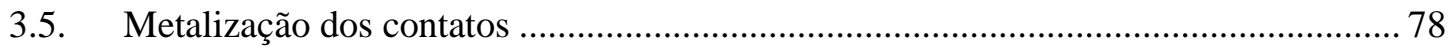

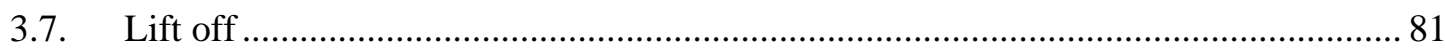

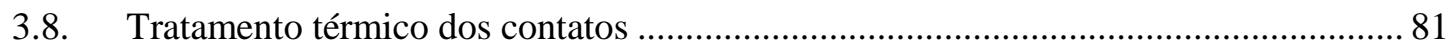

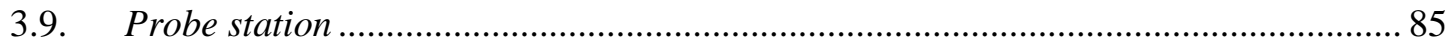

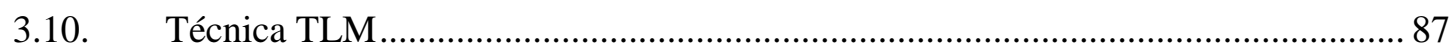

3.11. Microscopia de Força Atômica .............................................................................. 89

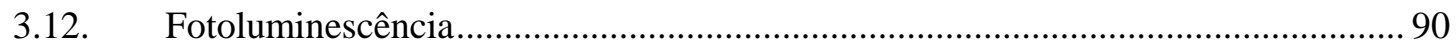

3.13. Absorção e eficiência quântica.............................................................................. 92

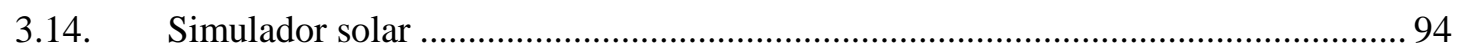

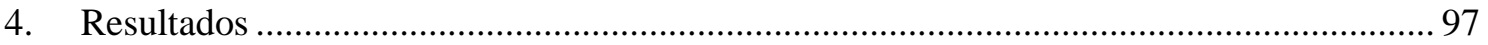

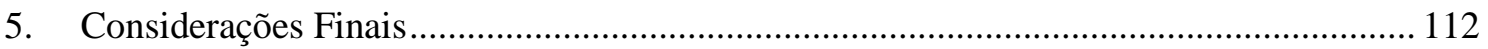

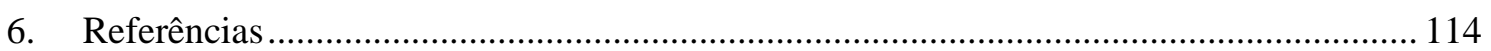

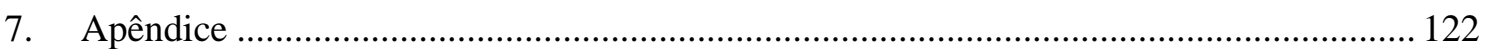

7.1. Consideração sobre o uso do padrão AM1.5G ………………………………......... 122

7.2. Geometria da máscara para o processamento dos "fingers" ...................................... 123

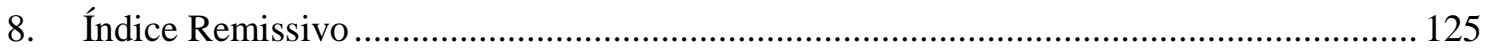




\section{Introdução}

No panorama mundial, o crescente consumo de energia, associado à escassez e à elevação do custo dos combustíveis fósseis, assim como o impacto ambiental no uso destes combustíveis (poluição, aquecimento global), levaram o mercado a buscar fontes alternativas de energia e despertaram o interesse da comunidade científica pela pesquisa por novas fontes renováveis, limpas e mais baratas [2]. Dentre as alternativas tais como energia eólica, geotérmica, e até nuclear (apesar dos problemas de segurança e de armazenamento dos dejetos radioativos), a energia solar preenche todos os requisitos, uma vez que o seu acesso é amplo e o custo vem se tornando cada vez mais competitivo [2] [3] [4]. Em termos práticos, ela pode ser considerada uma fonte inesgotável e possui a grande vantagem de não produzir qualquer tipo de resíduo no processo de geração.

A energia solar pode ser aproveitada basicamente de duas maneiras: pelo uso de aquecedores solares ou pela conversão fotovoltaica. Aquecedores solares são sistemas onde a luz solar aquece diretamente um fluido que pode ser usado como tal (em chuveiros ou torneiras domésticas) ou que pode ser levado à ebulição (por métodos de concentração dos raios solares) para acionar turbinas que irão gerar energia elétrica (como em centrais térmicas convencionais). Já, no aproveitamento da energia solar pelo uso de células fotovoltaicas, a radiação eletromagnética do espectro solar é absorvida e é gerada uma potência elétrica que pode ser usada para alimentar circuitos externos. O Sol, distante $147.500 .000 \mathrm{~km}$ da Terra no periélio de 4 de janeiro de 2001 [5] [6], faz incidir sobre ela uma irradiância de 1366,1 W/m² [7] [8]. A atmosfera terrestre reflete e absorve parte dessa radiação, o que faz com que chegue ao nível do mar cerca de $1000 \mathrm{~W} / \mathrm{m}^{2}$ quando o sol está no zênite [9]. Levando em conta os períodos noturnos, as variações sazonais e a ocorrência de nebulosidade, é possível fazer um levantamento da intensidade média anual incidente (irradiância) que chega em cada uma das regiões do globo, como ilustrado na Figura 1. Fica evidente que o Brasil é uma região privilegiada, onde a irradiância anual média varia de 210 a $260 \mathrm{~W} / \mathrm{m}^{2}$. A Figura 1 também revela uma outra informação extremamente importante: a área dos 6 discos pretos representa a superfície do planeta que poderia ser coberta por dispositivos de conversão de energia solar (com a tecnologia desenvolvida até 2016) para produzir a energia necessária para o consumo do planeta inteiro, ilustrando claramente o enorme potencial desta forma de energia [10] [11]. Para isso bastariam células solares com eficiência de conversão de apenas $8 \%$, pois produziriam, em média, $18 \mathrm{TW}$. Isso é mais do que a demanda mundial total de 2016 [12] [13], que corresponde 14,65 $\mathrm{TW}^{1}$, dos quais somente 2,68 TW foram disponibilizados na forma de eletricidade [14]. Essa parcela de eletricidade corresponde a todas as formas de geração.

\footnotetext{
${ }^{1}$ É possível chegar a esse valor a partir das figuras 1 e 2.
} 

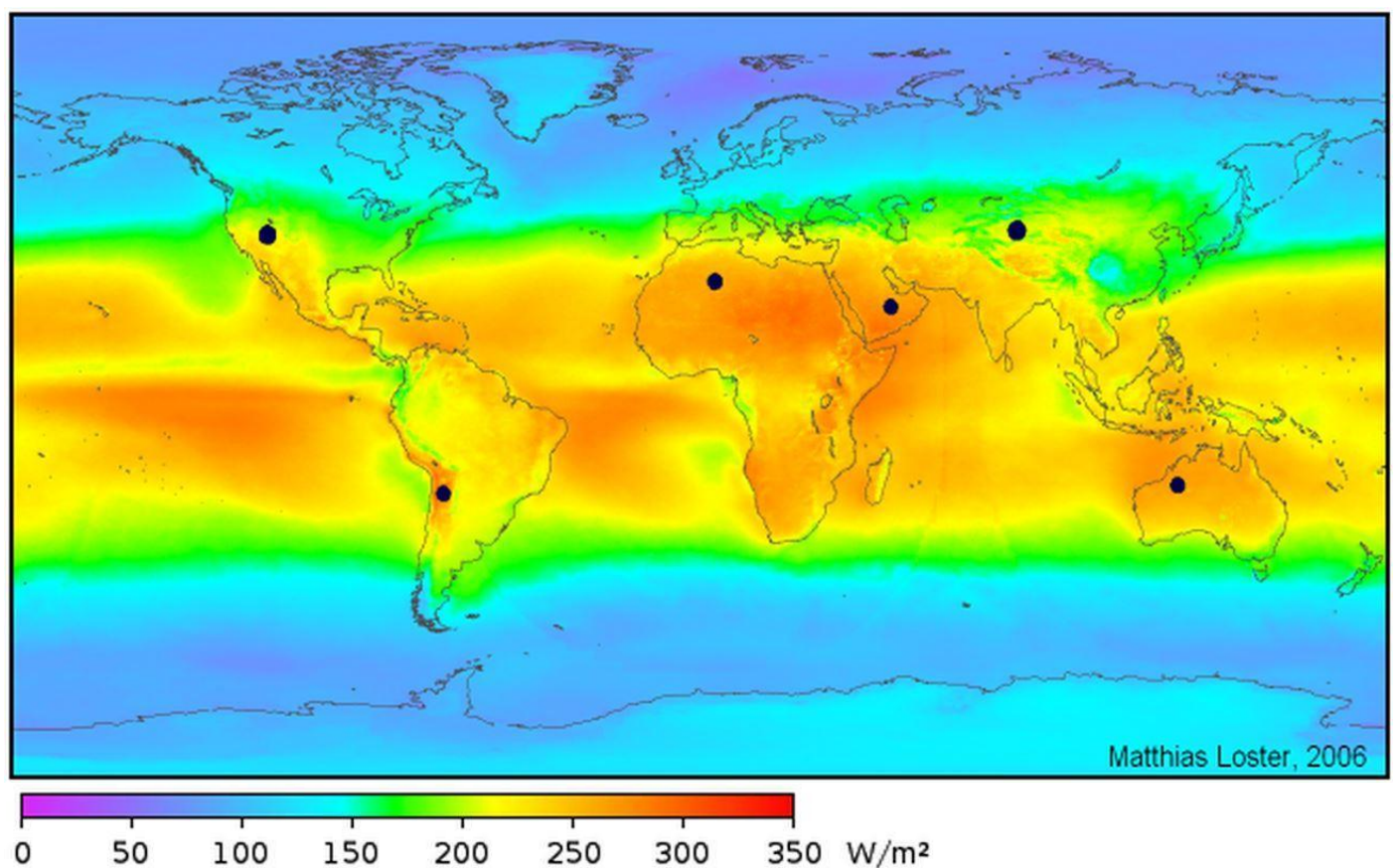

Figura 1: Irradiância (potência luminosa de origem solar por metro quadrado) média anual no nível do mar. Os discos pretos representam a área a ser coberta por módulos fotovoltaicos para satisfazer o consumo energético mundial a partir da energia solar. As cores mostram uma média de três anos, incluindo noites e cobertura de nuvens [10].

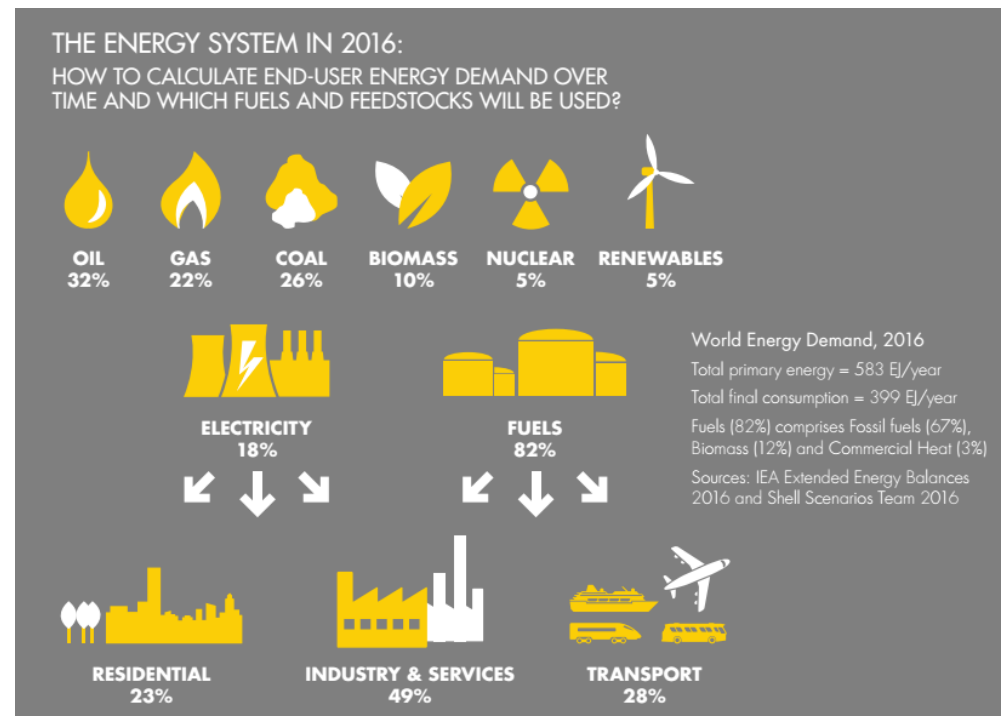

Figura 2: Demanda mundial de energia em 2016 [12]. 


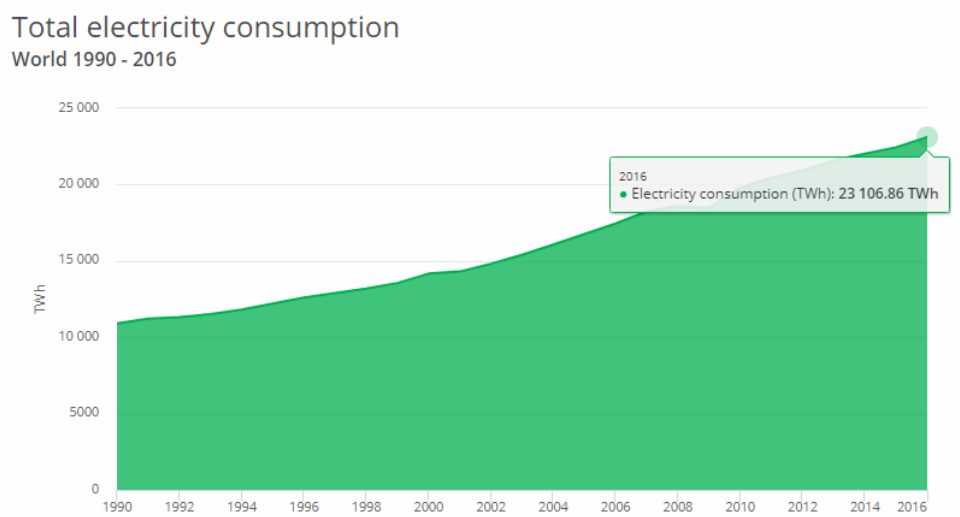

Figura 3: Consumo total de energia elétrica em 2016. O consumo de energia elétrica no mundo em 2016 seria suprido pela geração de aproximadamente 2,638 TW [13].

No cenário mundial a energia renovável, gerada a partir de recursos naturais, empregou 10,3 milhões de pessoas no mundo em 2017 (figura 4), direta ou indiretamente (aumento de 5,3\% em relação a 2016). Esse valor envolve fontes como hidroeletricidade, energia solar fotovoltaica (PV), energia solar por aquecimento, bioenergia e energia eólica. O levantamento foi elaborado pela Agência Internacional de Energia Renovável (Irena) [15].

\begin{tabular}{|l|c|}
\hline Solar fotovoltaica & 3.365 .000 \\
\hline Biocombustível & 1.931 .000 \\
\hline Grandes hidrelétricas & 1.514 .000 \\
\hline Energia eólica & 807.000 \\
\hline Aquecimento solar & 780.000 \\
\hline Biomassa & 344.000 \\
\hline Biogás & 290.000 \\
\hline Pequenas hidrelétricas & 93.000 \\
\hline Energia geotermal & 34.000 \\
\hline Energia solar térmica & 28.000 \\
\hline Energia de resíduos industriais & 1.000 \\
\hline Ondas do oceano & 8.000 \\
\hline Outros &
\end{tabular}

Figura 4: Empregos gerados no mundo pela tecnologia da energia renovável em 2017, com a liderança da energia solar fotovoltaica. Fonte: Irena. Infográfico elaborado em: 24/09/2018.

Em 2017, o incremento da capacidade mundial de geração de energia elétrica por meio do emprego da tecnologia solar fotovoltaica foi maior do que o de qualquer outro tipo de tecnologia de geração, superando a capacidade líquida de combustíveis fósseis e nuclear combinados [2]. No mesmo ano, foi a principal fonte de incremento na capacidade de geração de energia em vários mercados importantes como China, Índia, Japão e Estados Unidos. Ao menos $98 \mathrm{GW}$ de capacidade fotovoltaica foram instalados no mundo todo, considerando-se tanto os sistemas que foram integrados à rede como os que não foram conectados, aumentando a capacidade total em quase um terço e um total acumulado de $402 \mathrm{GW}$ (Figura 5). Mais de 40 mil painéis foram instalados a cada hora do ano [2]. 


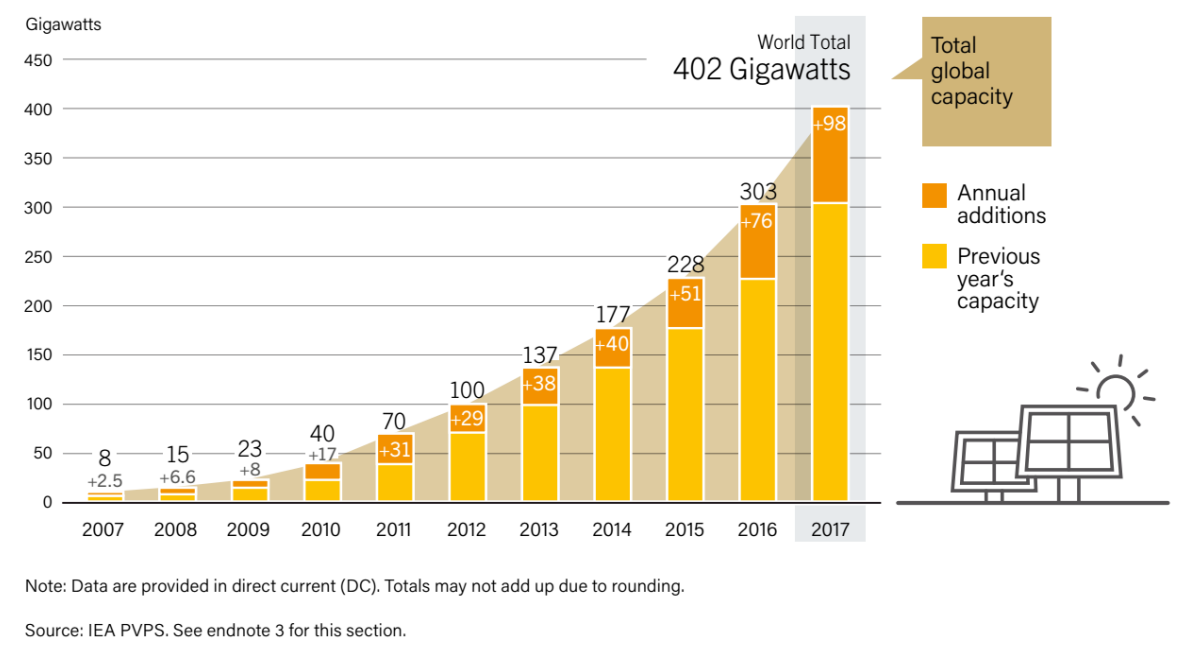

Figura 5: Capacidade mundial de geração de energia por sistemas fotovoltaicos e adições ocorridas entre 2007 e 2017 [2].

O aumento significativo do mercado em relação a 2016 deve-se principalmente à China (figura 6), onde houve um aumento de $50 \%$ por meio de novas instalações. O mercado indiano dobrou, enquanto alguns mercados importantes (Japão e Estados Unidos) se contraíram. Pelo quinto ano consecutivo, a Ásia eclipsou todas as outras regiões, sendo responsável por $75 \%$ das adições globais [2]. Os cinco maiores mercados nacionais - China, Estados Unidos, Índia, Japão e Turquia - foram responsáveis por quase $84 \%$ da capacidade instalada; os cinco maiores mercados nacionais seguintes no ranking, em ordem decrescente, foram Alemanha, Austrália, República da Coreia, Reino Unido e Brasil [2]. Para a capacidade de geração fotovoltaica total acumulada, os principais países foram China, Estados Unidos, Japão, Alemanha e Itália, com a Índia não muito longe [2].

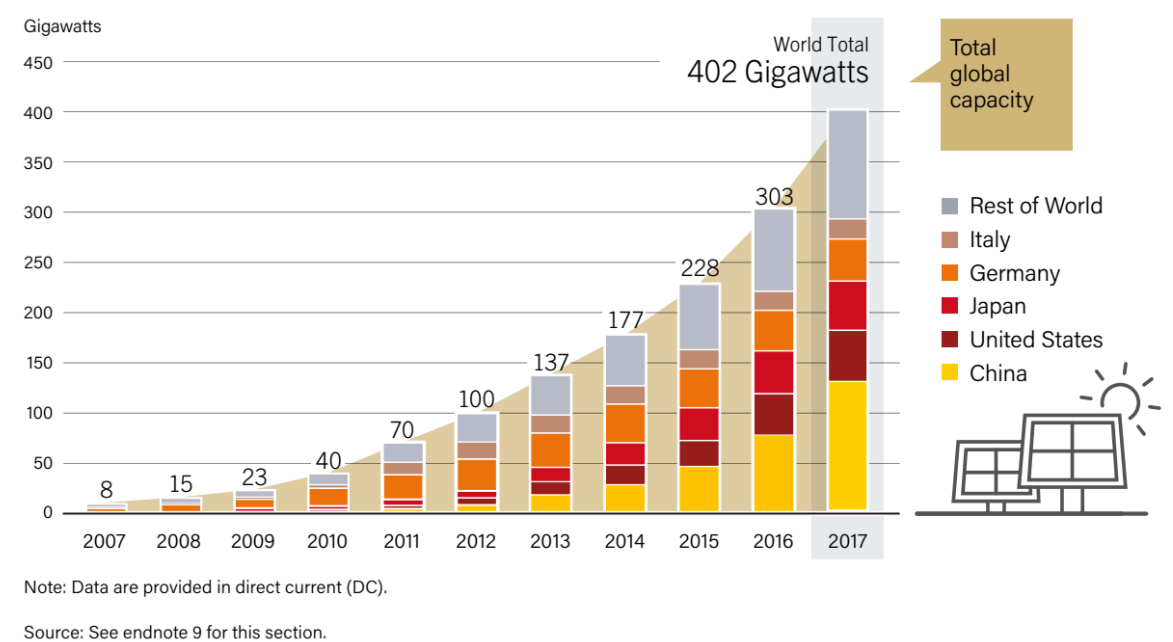

Figura 6: Capacidade mundial de geração de energia por sistemas fotovoltaicos por país ou região entre 2007 e 2017 [4].

No final de 2017, todos os continentes tinham instalado pelo menos $1 \mathrm{GW}$ e pelo menos 29 países tinham $1 \mathrm{GW}$ ou mais de capacidade [2]. Os líderes da capacidade de geração de energia pela tecnologia fotovoltaica, por habitante, eram Alemanha, Japão, Bélgica, Itália e Austrália [2]. 
Globalmente, a expansão do mercado deveu-se em grande parte à crescente competitividade da energia solar PV combinada à crescente demanda por eletricidade nos países em desenvolvimento, bem como à crescente conscientização do potencial da energia solar PV para aliviar a poluição, reduzir as emissões de $\mathrm{CO}_{2}$ e fornecer acesso à energia. A maior parte dessa demanda ainda continua sendo impulsionada principalmente por incentivos e regulamentos governamentais [2]. Ainda há desafios a serem enfrentados antes que a energia solar fotovoltaica possa se tornar uma importante fonte de eletricidade no mundo todo, embora vários países - como Alemanha, Grécia, Honduras e Itália - já abasteçam parcelas significativas de sua demanda de eletricidade com energia solar PV. Em 2017, a China superou todas as expectativas, acrescentando mais capacidade fotovoltaica solar (quase 53,1 GW) do que foi adicionado mundialmente em 2015 (51 GW, figura 7) [2].

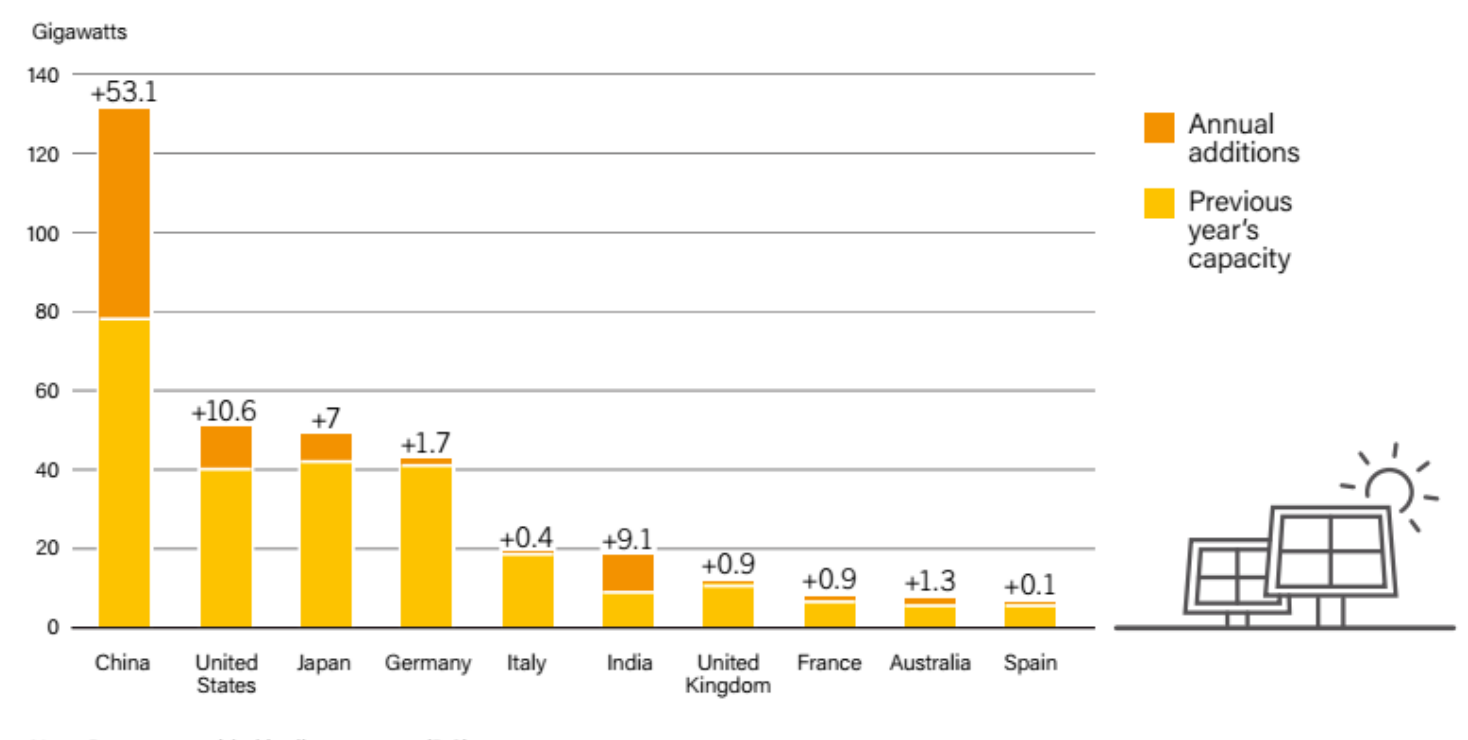

Note: Data are provided in direct current (DC).

Figura 7: Capacidade mundial de geração de energia por sistemas fotovoltaicos e adições ocorridas nos países que mais geraram em 2017 [4]

Dentre todas as fontes de geração de energia elétrica chinesas, a que teve o maior incremento na capacidade de geração em 2017 foi, pela primeira vez, a energia solar fotovoltaica, com total de instalações de cerca de $131,1 \mathrm{GW}$, superando em muito a meta mínima do governo para $2020(105 \mathrm{GW})$, anunciada em $2016 \mathrm{com}$ os objetivos de promover o desenvolvimento econômico, a redução da pobreza e a proteção ambiental [2]. A China responde por mais da metade da demanda global por manufatura de células fotovoltaicas. Por isso os desenvolvimentos nesse país têm um forte impacto no mercado mundial de geração de energia fotovoltaica [2].

No que diz respeito ao Brasil, a fonte solar fotovoltaica vive um crescimento considerável, com benefícios econômicos, sociais e ambientais cada vez mais importantes para nossa sociedade. Segundo relato da Associação Brasileira de Energia Solar Fotovoltaica (ABSOLAR) do final de 2018, o país possui uma potência instalada de mais de 1,6 GW, total alcançado por menos de 30 países no mundo. A Empresa de Pesquisa Energética (EPE) estima que essa fonte de energia deverá representar, numa estimativa conservadora, mais de $10 \%$ da matriz elétrica brasileira em 2030, enquanto hoje representa menos de 1\%. A Bloomberg News Energy Finance afirma que, em 2040, a energia solar fotovoltaica no Brasil será $32 \%$ da matriz energética e ultrapassará a fonte hídrica, que será de $29 \%$ [3] [4]. O crescimento só não é maior porque as pessoas ainda 
acham que o investimento inicial é muito alto [3]. No entanto, pressionados pelos custos da energia elétrica, os consumidores têm buscado opções para enfrentar os pesados aumentos nas tarifas. A geração distribuída ${ }^{2}$ solar fotovoltaica se destaca como uma solução competitiva e sustentável: os preços dos sistemas caíram $75 \%$ na última década e o tempo de retorno sobre o investimento diminuiu, trazendo reduções de até $90 \%$ nas contas de energia elétrica [4]. Normalmente o que ocorre é que, no final do mês, a concessionária mede dois números - tudo que se consumiu e o que se gerou - e concede um abatimento na conta do consumidor [4].

Em 2017, o reajuste médio anual das tarifas das distribuidoras foi superior a 10\%, frente a uma inflação de 2,95\%. Hoje, o retorno de quem fizer a instalação de módulos fotovoltaicos varia entre três e sete anos, dependendo da irradiância e das tarifas de energia. Os equipamentos têm garantia de 25 anos, mas há casas na Europa onde eles chegam a durar 35 anos. Há ainda a possibilidade de se economizar nos investimentos com a infraestrutura da rede de distribuição, como ocorreu na Califórnia (EUA), onde os investimentos da população em geração distribuída e eficiência energética trouxeram uma economia de US $\$ 2,6$ bilhões aos californianos, com o cancelamento de 20 projetos de transmissão e redução de 21 projetos de reforço de rede [3].

A exploração da fonte de energia fotovoltaica - ainda em processo de desenvolvimento no Brasil - tem sido uma das mais democráticas e socialmente acessíveis. A tecnologia tem sido incorporada em casas populares, como nos programas habitacionais do CDHU-SP (Companhia de Desenvolvimento Habitacional e Urbano de São Paulo), AGEHAB-GO (Agência Goiana de Habitação de Goiás) e no Programa Minha Casa Minha Vida, do Governo Federal, aliviando os custos da população mais vulnerável, para que possam melhorar a alimentação, saúde, educação, transporte e qualidade de vida [2] [3]. O Brasil tornou-se o segundo país da região (depois do Chile) a exceder $1 \mathrm{GW}$ de capacidade solar fotovoltaica instalada, adicionando quase tudo em um único ano (0,9 GW em 2017) para acumular um total de 1,1 GW [2]. Com isso, o Brasil subiu para a décima posição global pela capacidade acrescentada em 2017. Mas o país ainda é responsável por somente $1 \%$ das adições globais [2] [8].
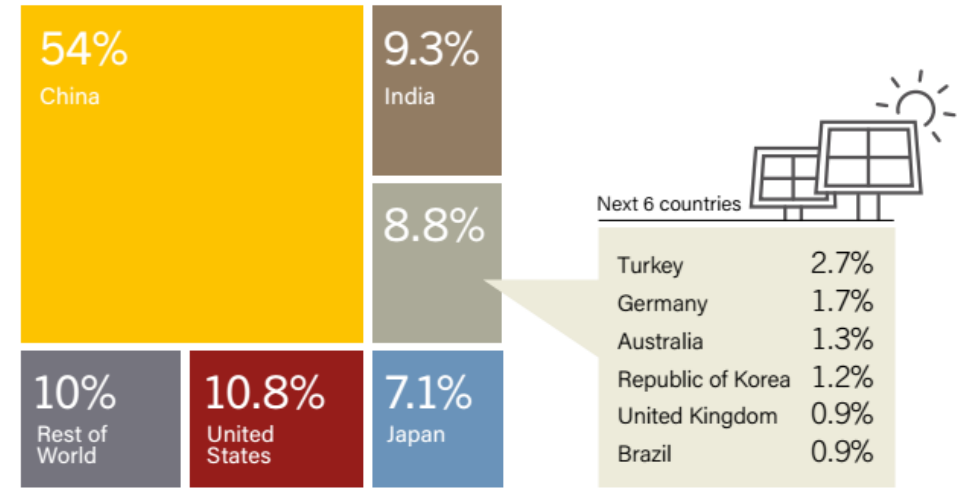

Source: See endnote 98 for this section.

Figura 8: Adições na capacidade mundial de geração de energia por sistemas fotovoltaicos, nos 10 países que mais geraram e no resto do mundo, em 2017 [4].

Os módulos fotovoltaicos geralmente disponíveis no mercado são feitos de silício (formados por uma única junção $\mathrm{PN}^{3}$ de $\mathrm{Si}$ ), pois trata-se de um material semicondutor barato, abundante, e que pode ser facilmente produzido com alta pureza em escala industrial. Apesar de

\footnotetext{
${ }^{2}$ Geração distribuída é a que é gerada próxima ao consumidor.

${ }^{3}$ Abordaremos em detalhes esse conceito no tópico 2.3 desse trabalho.
} 
serem relativamente baratas, essas células solares possuem geralmente uma baixa eficiência. Cálculos (limite de Shockley-Queisser ${ }^{4}$ ) mostram que a eficiência teórica máxima de conversão da energia solar em energia elétrica para uma única junção PN é 33,16\% [16]. Valores de 28,8\% podem ser obtidos em laboratório, com células de GaAs de única junção PN [17], mas os grandes painéis comercializados nos últimos 10 anos (feitos com Si policristalino) costumam apresentar uma eficiência entre 12 e $17 \%$ [18].Para melhorar a eficiência das células solares, tem-se pesquisado novos materiais semicondutores ou estruturas tais como o arseneto de gálio (GaAs), células de junções múltiplas (células compostas por várias camadas sobrepostas de diferentes materiais, cada uma absorvendo uma faixa específica do espectro solar), e células contendo nanoestruturas (fios, poços e pontos quânticos), que possibilitam a criação de níveis de energia intermediários, permitindo que fótons de mais baixa energia possam ser absorvidos. Com estas tecnologias aliadas a sistemas de concentração dos raios solares (usando lentes, geralmente chamadas de concentradores), a eficiência teórica máxima se aproxima de 86\% [8], sendo que, em laboratório, uma eficiência de $46 \%$ já foi demonstrada [19].

Uma maneira de favorecer o desenvolvimento das células solares como fonte de energia limpa e competitiva é aumentar a sua eficiência. Infelizmente, esta filosofia é geralmente acompanhada por um aumento do custo de produção, visto que essas células mais eficientes são fabricadas a partir de materiais semicondutores monocristalinos de alta pureza por técnicas sofisticadas de crescimento como a epitaxia por feixes moleculares (MBE, molecular beam epitaxy). Uma outra maneira de incentivar o amplo uso deste tipo de energia é produzir um produto mais barato que as células convencionais de Si monocristalino, mesmo se ele for menos eficiente. É por isso que, nos últimos anos, surgiram células fabricadas com outros tipos de materiais tais como o Si policristalino, ou com filmes finos de Si amorfo, de CIGS (liga de $\mathrm{Cu}: \mathrm{In}: \mathrm{Ga}: \mathrm{Se}$ ), ou ainda de polímeros, que podem ser depositados até sobre substratos flexíveis.

O NREL (National Renewable Energy Laboratory) [19], localizado nos EUA, atualiza anualmente os dados da figura 9, onde são mostrados os recordes de eficiência alcançados por todos os tipos de células solares conhecidas. Essa figura mostra que o recorde absoluto de eficiência é o de células de múltiplas junções que fazem uso de concentradores solares. Para o GaAs, que é o material utilizado nos substratos das células produzidas nesse trabalho, o recorde mundial, segundo o NREL, para as células monocristalinas, é de 27,8\% (alcançado pela LG), enquanto que para células de filmes finos é de 29,1\% (alcançado pela Alta Devices).

\footnotetext{
${ }^{4}$ Isso será abordado no tópico 2.8 .
} 
Best Research-Cell Efficiencies

MNREL

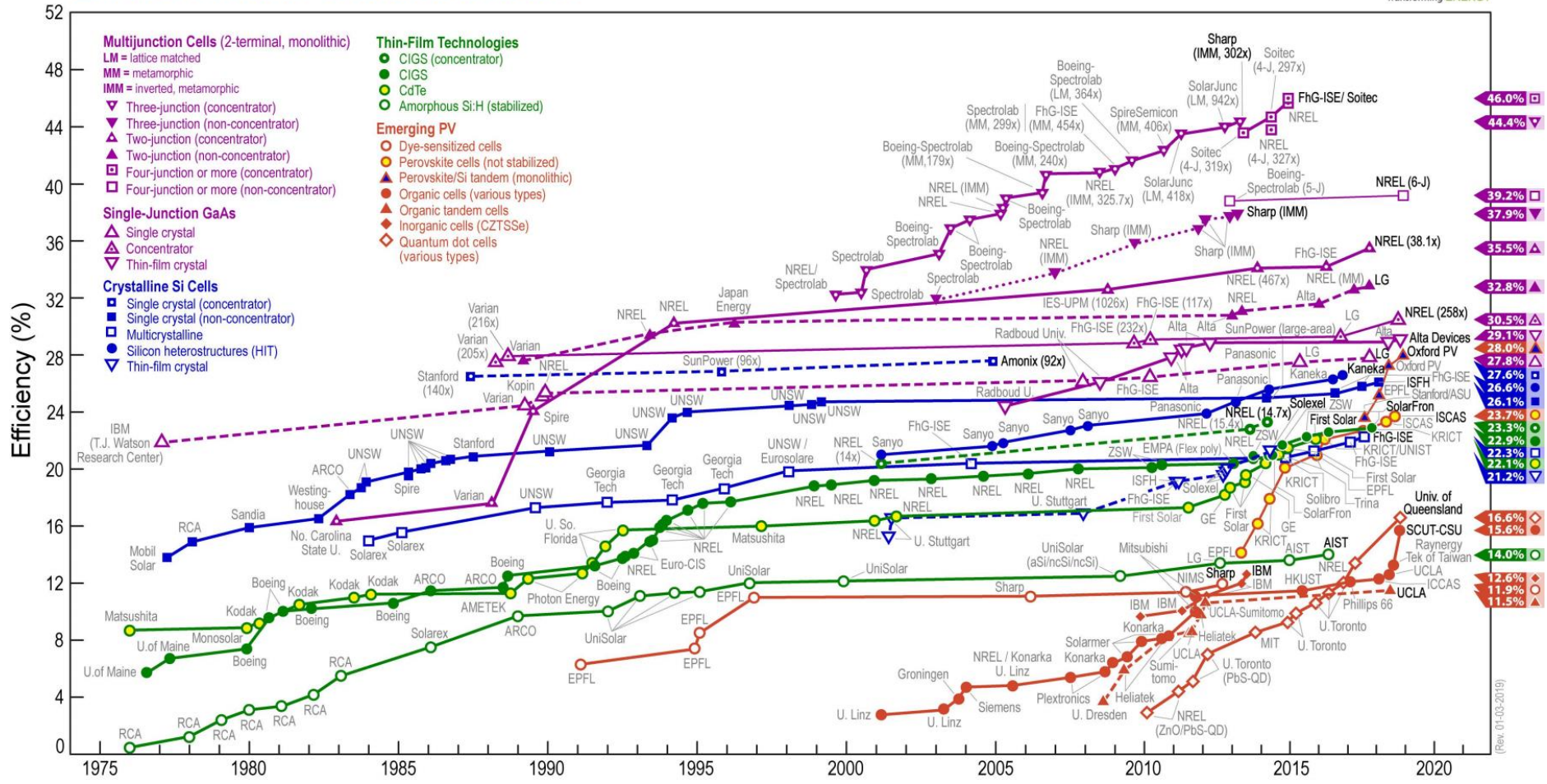

Figura 9: Evolução da eficiência de conversão de vários tipos de células solares em função do tempo. À direita temos a eficiência máxima obtida até agora para cada tecnologia [19].

Devido à crescente atração pela geração fotovoltaica como uma opção na promoção do desenvolvimento econômico, na redução da pobreza e para a proteção ambiental [2], esta dissertação procura compreender os esforços feitos até então e ser um material de referência para futuros progressos nessa área. Descrevo neste trabalho a tecnologia fotovoltaica e mostro detalhes de como construir uma célula solar, além de um entendimento preliminar de como tornar as células fotovoltaicas mais eficientes através da inserção de pontos quânticos em sua estrutura.

Os principais objetivos desse trabalho foram iniciar no laboratório uma nova linha de pesquisa relacionada com o desenvolvimento de células solares, fabricar uma célula solar de GaAs de boa qualidade que poderia ser usada como referência, e investigar o efeito da introdução de pontos quânticos de InAs crescidos pela técnica de epitaxia por feixes moleculares $\left(\mathrm{MBE}^{5}\right)$. Quando se trabalha com células de GaAs (que é o material disponível em nosso sistema MBE), a principal meta não pode ser com os dispositivos de Si em aplicações usuais, já que esses são muito mais baratos e fáceis de serem desenvolvidos em maior escala. Portanto, para que esse tipo de pesquisa tenha algum sentido de ponto de vista das aplicações, procuramos nichos específicos necessitando de dispositivos mais eficientes que os de $\mathrm{Si}$, justificando assim seus preços mais altos, e possibilitando o financiamento das agências de fomento e a publicação de resultados científicos em revistas especializadas. Esses nichos de aplicação são concentrados, principalmente, no desenvolvimento de dispositivos de espaçonaves, carros, drones [20], satélites e aplicações militares. As células de GaAs são atualmente os dispositivos de uma única junção que possuem o recorde de eficiência, e por isso proporciona uma grande vantagem no uso nas superfícies limitadas de espaçonaves, carros ou pequenos satélites.

\footnotetext{
${ }^{5}$ MBE, do inglês "molecular beam epitaxy".
} 
O presente trabalho foi desenvolvido no Laboratório de Novos Materiais Semicondutores do Instituto de Física da Universidade de São Paulo (LNMS/IFUSP) que já possui bastante experiência no crescimento de heteroestruturas semicondutoras pela técnica de epitaxia por feixes moleculares e na fabricação e testes de fotodetectores de radiação infravermelha. Todavia, como este é o primeiro trabalho que trata da construção e caracterização de células solares, uma parte dos esforços foi empregada no sentido de adquirir e sedimentar conhecimentos básicos sobre a produção e a caracterização de células solares para que fosse criada uma base sobre a qual o LNMS pudesse desenvolver trabalhos futuros.

Para tanto, perseguimos os seguintes objetivos específicos:

(i) Entender os conceitos físicos relativos à tecnologia fotovoltaica;

(ii) Entender como construir uma célula solar (CS);

(iii) Entender como devem ser crescidas as amostras para a construção das CSs através da técnica de epitaxia por feixes moleculares (MBE);

(iv) Entender as etapas da fotolitografia e estabelecer procedimentos para processar boas CSs;

(v) Estabelecer um procedimento para produzir contatos ôhmicos de boa qualidade;

(vi) Compreender os procedimentos e experimentos necessários para caracterizar as estruturas das CSs.

(vii) Testar o efeito da introdução de algumas estruturas básicas nas células solares, a partir de uma estrutura padrão PIN de GaAs de referência, como a introdução de uma fina camada de AlGaAs no topo da junção (FSF, janela) ou na sua parte inferior (BSF), assim como de pontos quânticos de InAs.

Na próxima seção, "2. Teoria", menciono um pouco a história do desenvolvimento da tecnologia fotovoltaica, apresento alguns conceitos essenciais - como diagrama de bandas, junções PN e PIN, dentre outros - utilizados para explicar como a dinâmica do fenômeno fotovoltaico gera potência elétrica útil, a partir da luz do sol, e, também, para entender a origem das limitações no desempenho dos dispositivos fotovoltaicos como os mecanismos de perda por recombinações dos portadores de carga e a quantidade limitada de fótons disponíveis no espectro solar, dentre outros fatores. Finalmente, apresento um resumo sobre o conceito de pontos quânticos que serão usados na tentativa de melhorar o desempenho dos dispositivos.

Na seção seguinte, “3. Materiais e métodos", apresento as técnicas e equipamentos utilizados nesse trabalho para a produção das células solares, como a técnica epitaxial de feixes moleculares para o crescimento das amostras, o processamento e a construção dos contatos, dentre outros. Também apresento nessa seção as técnicas e equipamentos para caracterizar as amostras, como a microscopia por força atômica, a fotoluminescência, o método $\mathrm{TLM}^{6}$ para avaliar a qualidade dos contatos e o simulador solar.

Na penúltima seção, “4. Resultados", são apresentados os resultados dos testes para a caracterização dos contatos e das células solares construídas, assim como uma discussão sobre o significado desses resultados, além de comparações com a literatura.

Finalmente encerro com a seção, "5. Considerações Finais", tecendo considerações sobre os pontos mais essências dessa dissertação.

\footnotetext{
${ }^{6}$ TLM, do inglês "Transmission Line Method", em português pode ser traduzido por Método de linha de transmissão. Serve para estimar a resistência dos contatos das células solares.
} 


\section{Teoria}

\subsection{História do efeito e da tecnologia fotovoltaicos}

O efeito fotovoltaico consiste no estabelecimento de uma fonte geradora de corrente elétrica por meio da incidência da luz ou de radiação similar. A sucessão de eventos que culminaram no que chamamos hoje de Efeito Fotovoltaico foi iniciada pelos trabalhos de Alexandre Edmond Becquerel no ano de 1839, quando, em suas investigações sobre a geração de corrente, a partir de um experimento envolvendo a imersão de eletrodos de platina um eletrólito, expôs um de seus experimentos à luz e ocorreu uma mudança na intensidade da corrente gerada [21] [22] [23].

Em 1873, o engenheiro britânico Willoughby Smith e seu assistente Joseph May descobriram que o selênio semicondutor mudava sua resistência e se transformava em um condutor quando era exposto à luz. Essa propriedade é conhecida como fotocondutividade [24].

Em 1876, William Adams e Richard Day descobriram que o selênio vítreo conectado a eletrodos de platina poderia produzir energia elétrica quando fosse exposto à luz, o que mostrou, pela primeira vez, que um corpo sólido poderia converter diretamente a energia da luz em energia elétrica [21].

Em 1883, o inventor Charles Fritts construiu um pequeno dispositivo de $30 \mathrm{~cm}^{2} \mathrm{com}$ células de selênio, cobrindo as com um eletrodo muito fino de ouro, que alcançou uma eficiência próxima a 1\%. Esse dispositivo foi enviado a Werner von Siemens, inventor e empresário alemão (1816-1892) para avaliação, que reconheceu a importância e aplicou essa tecnologia no desenvolvimento de um instrumento de medição de iluminação baseado em selênio [21] [24].

Em 1887, o cientista alemão Henrich Hertz descreveu o fenômeno em que a radiação ultravioleta fazia saltar faíscas dos eletrodos de células fotovoltaicas [24].

Em 1888, Edward Weston patenteou pela primeira vez uma célula fotovoltaica com o título "Solar cell” que recebeu a identificação US389124 [25].

Em 1905, o efeito fotoelétrico foi explicado pela primeira vez por um artigo de Albert Einstein $(1879$ - 1955) [26].

Em 1916, o efeito fotoelétrico foi comprovado pela primeira vez em laboratório pelo cientista norte-americano Robert Millikan [24] e, no mesmo ano, o químico polonês Jan Czochralski, da AEG Company, descobriu o processo de crescimento de cristais que leva seu nome. Com o processo Czochralski, tornou-se possível produzir cristais semicondutores de alta qualidade [21].

Em 1931, o engenheiro alemão Bruno Lange desenvolveu uma fotocélula utilizando seleneto de prata entre duas placas de cobre puro. Isso resultou numa célula $150 \%$ mais potente que a célula de seu trabalho anterior que utilizava o oxido de cobre no lugar do seleneto de prata [27].

Em 1946, o norte americano Russell S. Ohl patenteou uma célula solar moderna sob o título "Light-Sensitive Electric Device" [28].

Em 1950, o co-inventor do transistor e Prêmio Nobel Americano. William B. Shockley (1910-1989), apresentou uma explicação do funcionamento da junção PN.

Em 1954, Daryl Chapin, Calvin Fuller e Gerald Pearson desenvolveram na Bell Labs a primeira célula solar de silício com uma área de $2 \mathrm{~cm}^{2}$ e uma eficiência de até $6 \%$. A célula produzida na Bell Labs combinou o conceito da junção PN com o efeito fotônico interno. A junção PN serviria como transportador dos elétrons fotogerados e, com isso, o fenômeno de geração de potência elétrica pela incidência da luz foi identificado como o efeito fotônico da camada de depleção ou também como efeito fotovoltaico [21]. O New York Times anunciou, em 26 de abril de 1954, que a célula solar de silício "poderia ser o marco início de uma nova era, levando 
eventualmente à realização de um dos maiores sonhos da humanidade - o aproveitamento da energia quase ilimitada do sol para o uso da civilização" [29].

Apesar de, nos anos seguintes, a eficiência continuar aumentando, inicialmente os módulos solares foram utilizados apenas em aplicações especiais devido aos seus altos preços (o Watt era cerca de 1000 vezes mais caro do que hoje). Nessa área, a autonomia energética por longos períodos proporcionada às máquinas em orbita, sem a adição do peso do combustível, compensava o custo do uso da tecnologia fotovoltaica.

No dia 17 de março de 1958 o Vanguard 1 [30] foi o primeiro satélite lançado com células solares a bordo, e um dos seus transmissores, que extraiu energia de seis células solares, operou até 1964 [21]. Com isso, o tempo de autonomia dos dispositivos utilizados nas missões espaciais, que antes era da ordem de 6 meses, aumentou consideravelmente e chegou, no caso do Vanguard 1, a mais de 15 anos.

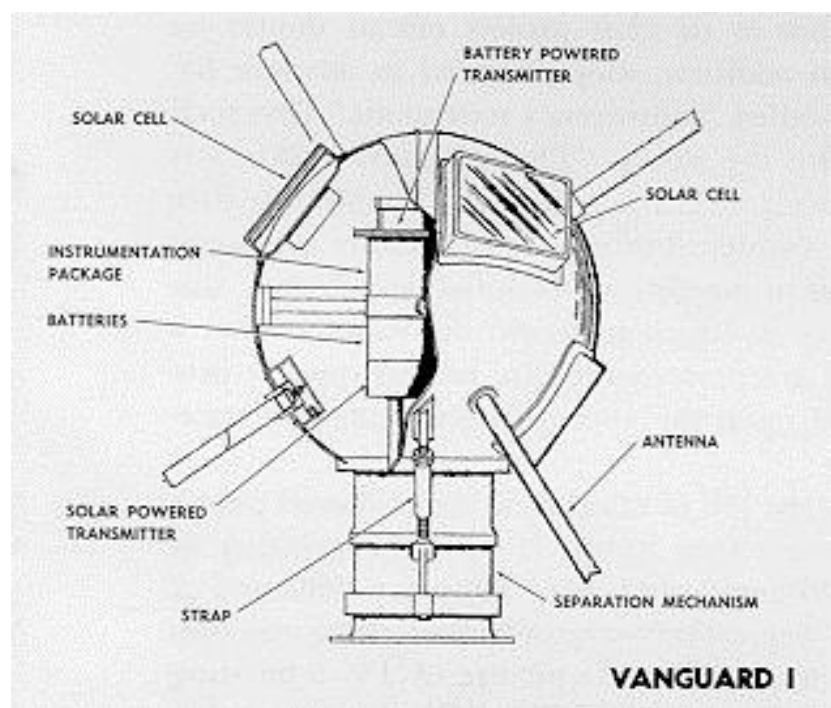

Figura 10: Esquema do satélite Vanguard I. Por causa do seu diâmetro de $16 \mathrm{~cm}$, também foi chamado "Grapefruit" (foto: NASA) [30].

O sucesso deste projeto Vanguard 1 impulsionou tanto a exploração espacial nos anos 60 quanto a busca por materiais que poderiam proporcionar células solares mais eficientes, como o arseneto de gálio (GaAs) e outros materiais alternativos [21]. Como um dos desenvolvimentos subsequentes ao Vanguard I, a figura 11 mostra um dos dois módulos fotovoltaicos da sonda Dawn (2007) projetada para chegar ao planeta anão Ceres em fevereiro de 2015, com uma matriz de $5 \mathrm{~kW}$ formada por células empilhadas de três camadas de alta capacidade de InGaP /InGaAs /Ge com eficiência superior a 27,5\% no início da sua vida útil [31]. 


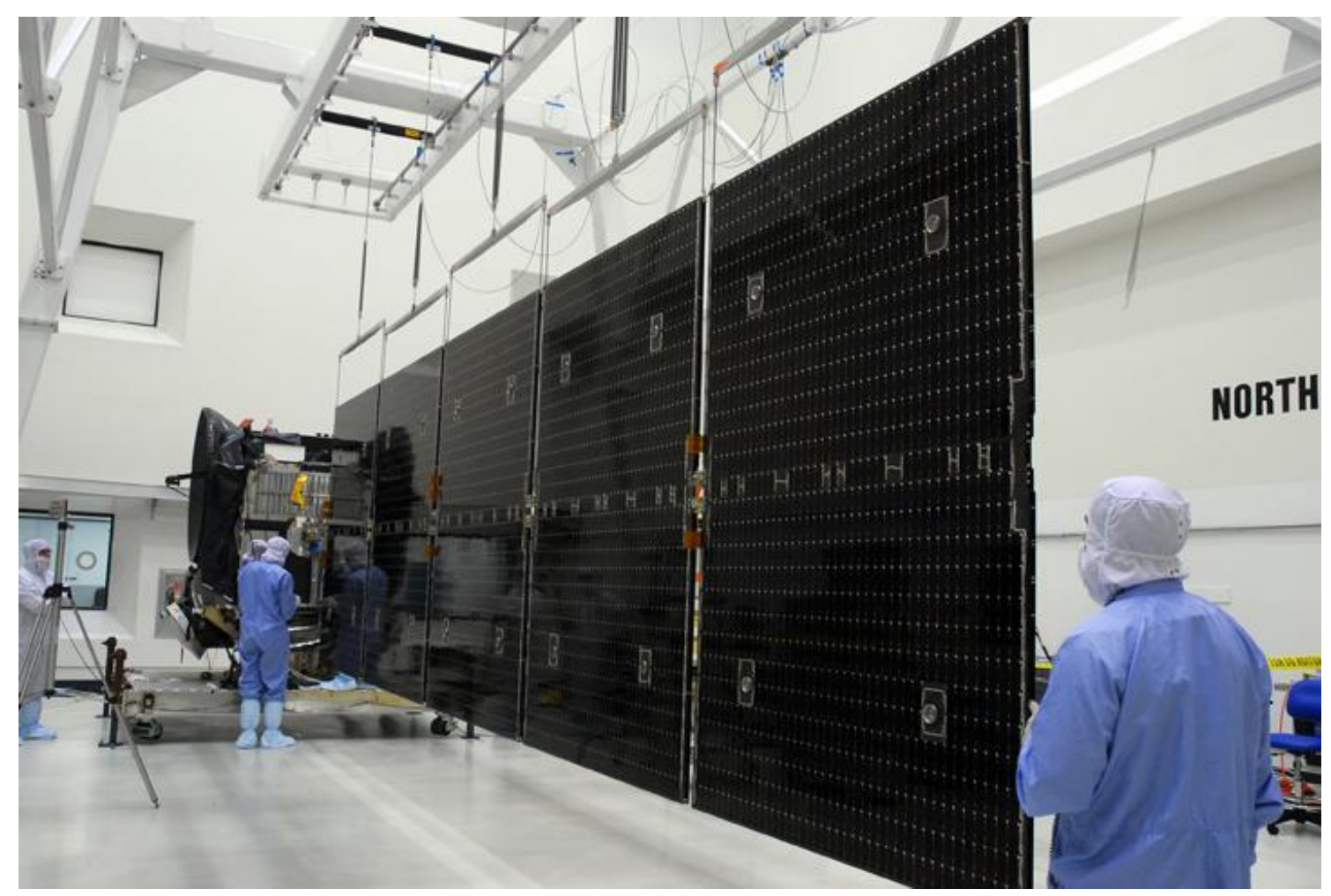

Figura 11: Sistema solar moderno da sonda espacial Dawn com potência de 5 kW [32].

A comercialização de módulos fotovoltaicos foi feita em 1959 quando a empresa Hoffman Eletronics disponibilizou células comerciais com 10\% de eficiência e começou a fazer uso de contatos em rede $^{7}$ que diminuiu significativamente a resistência em série [33] [34] [35].

\footnotetext{
${ }^{7}$ Para esses contatos em rede é utilizada a expressão "grid contact" nos textos em inglês e se refere ao desenho do padrão dos contatos superiores das células solares onde a luz deve incidir. Na otimização desse padrão são considerados, além da largura e altura dos fingers e busbar, as perdas resistivas no emissor, as perdas resistivas no contato superior e as perdas por sombreamento [35].
} 


\subsection{Definições Básicas}

Para entendermos como a absorção da luz produz corrente elétrica, precisamos conhecer o conceito de bandas de energia que surgem em materiais formados por um grande número de átomos. Essas bandas estão relacionadas com os níveis eletrônicos de átomos individuais (Figura 12) que, quando presentes em grande quantidade, próximos uns dos outros, e arranjados periodicamente na forma de um cristal, formam um conjunto contínuo de níveis muito parecidos, separados por regiões de energia proibida que darão origem ao gap $E_{G}$.

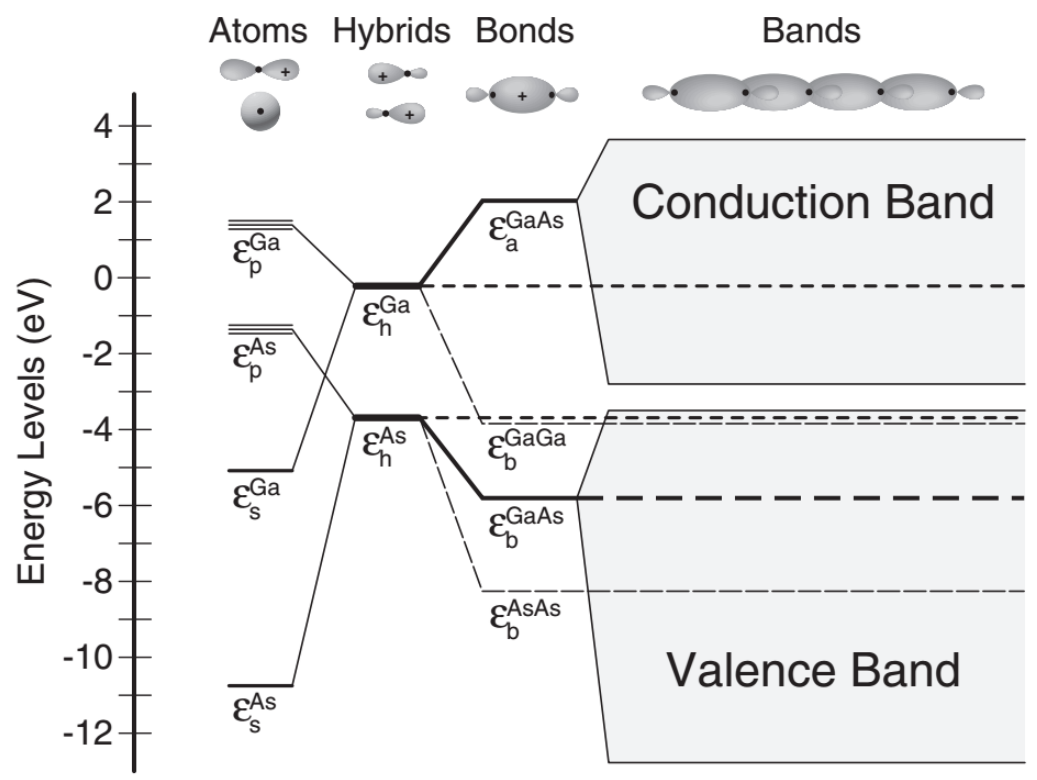

Figura 12: Diagrama de nível de energia para uma superfície de GaAs. Energias híbridas de gálio e arsênico $\left(\varepsilon_{h}^{G a}\right.$, $\left.\varepsilon_{h}^{A s}\right)$ não ligado (ligação pendente), bem como energias de ligação $G a-G a\left(\varepsilon_{b}^{G a G a}\right)$, As-As $\left(\varepsilon_{b}^{A s A s}\right)$ e $G a-A s\left(\varepsilon_{b}^{G a A s}\right)$ são mostradas [36].

As bandas relevantes para compreender as propriedades dos materiais semicondutores, utilizados na construção de dispositivos, são a banda de valência e a banda de condução (figura 13). As bandas de energia correspondem a intervalos de energia que os elétrons de um cristal podem possuir. Podemos definir dois tipos de banda. A banda de valência é o intervalo de valores de energia que está totalmente ocupado por elétrons na temperatura do zero absoluto, enquanto que a banda de condução é o intervalo de valores de energia que está totalmente desocupado na temperatura de zero absoluto. Entre essas duas bandas há um intervalo de energia proibida, chamado gap $\left(E_{G}\right)$, sem nenhum estado de energia ocupável. Portanto, um elétron que esteja com o máximo de energia na banda de valência só pode alcançar a banda de condução se receber, no mínimo, uma energia igual a $E_{G}$. 


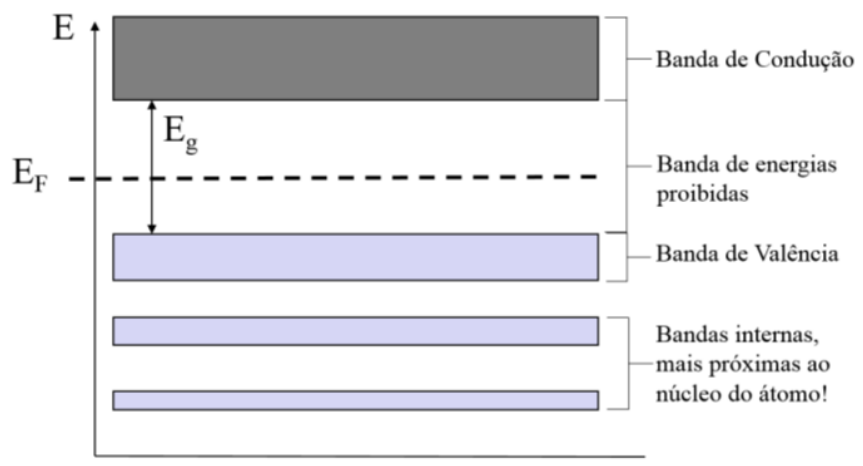

Figura 13: Banda de valência, banda de condução e o gap $E_{G}$.

O tamanho $E_{G}$ da banda proibida (Figura 14) diferencia condutores, semicondutores e isolantes (Figura 14). Materiais isolantes possuem um gap $E_{G}>3 \mathrm{eV}$, sendo que o gap dos semicondutores é $0<E_{G}<3 \mathrm{eV}$. Nesses dois casos, a banda de condução é sempre vazia a $0 \mathrm{~K}$ e pode ser populada numa temperatura superior devido à excitação térmica. Materiais condutores possuem uma banda de valência que invade a banda de condução, visto que $E_{G} \leq 0$, o que faz com que a banda de condução esteja sempre parcialmente ocupada, mesmo a $0 \mathrm{~K}$.

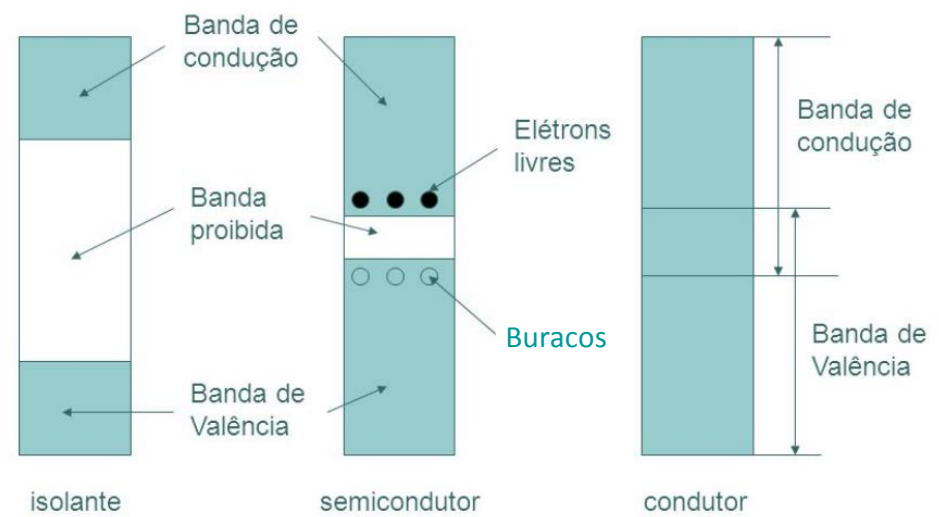

Figura 14: Representação das bandas de energia de isolantes, semicondutores e metais [37].

A energia de Fermi é a energia do nível ocupado mais alto do sistema a $0 \mathrm{~K}$. Numa temperatura diferente de $0 \mathrm{~K}$, o nível de Fermi é definido como o nível que, no equilíbrio térmico, possuí $50 \%$ de probabilidade de ser ocupado (figura 15). Assim, num semicondutor não dopado a $0 \mathrm{~K}$ ele está exatamente no meio da região proibida. Em materiais dopados ${ }^{8}$ do tipo $\mathrm{N}$, o nível de Fermi se aproxima da banda de condução, enquanto que nos materiais do tipo $\mathrm{P}$, o nível de Fermi fica mais próximo à banda de valência.

\footnotetext{
${ }^{8}$ A dopagem consiste em aumentar o número de elétrons ou de lacunas de um semicondutor através da inserção de átomos de elementos apropriados, diferentes do material matriz. No caso do GaAs cristalino utilizado neste trabalho, obtemos um material dopado do tipo $\mathrm{N}$ pela inserção de átomos de Si e um material dopado do tipo P pela inserção de átomos de C.
} 

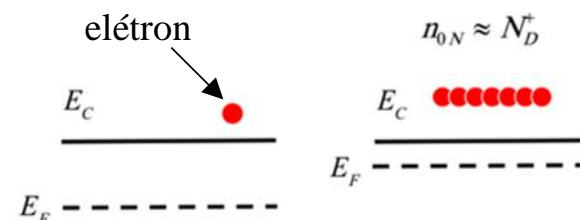

$p_{0 P} \approx N_{A}$

$E_{r}$
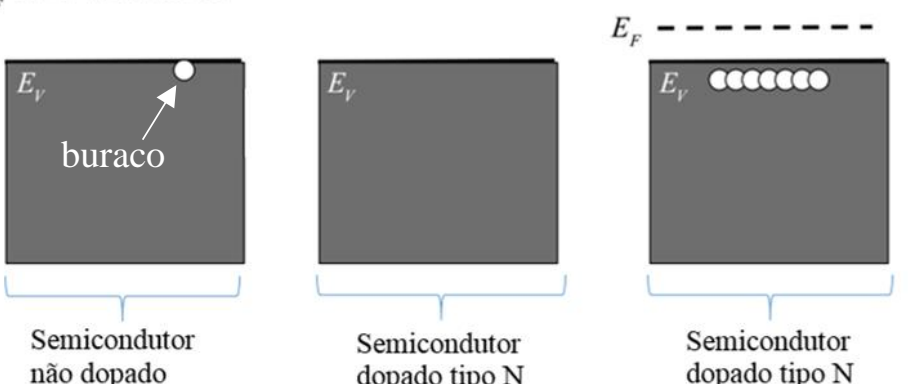

Figura 15: Relação da dopagem com a energia de Fermi $E_{F}$ em materiais onde são adicionados átomos de dopantes para se aumentar o número de elétrons, representados pelas bolas vermelhas (material tipo $N$ ), e em materiais onde há adição de átomos para que se crie buracos (também chamados de lacunas), representados pelas bolas brancas, (material tipo P) [38]. 


\subsection{Junção PN e junção PIN}

Existem dois mecanismos básicos necessários para a geração de potência por uma célula fotovoltaica. O primeiro disponibiliza portadores livres. $\mathrm{O}$ outro estabelece uma diferença de potencial que gera corrente a partir desses portadores livres. Uma forma de construir essa diferença de potencial é depositar um material tipo $\mathrm{N}$ sobre um material tipo $\mathrm{P}$, sistema conhecido como junção PN. Como o material tipo $\mathrm{N}$ tem uma alta concentração de elétrons e o material tipo $\mathrm{P}$ tem uma alta concentração de buracos (também chamadas lacunas), na região próxima a essa junção os elétrons difundem do lado $\mathrm{N}$ para o lado $\mathrm{P}$ deixando para trás cargas positivas fixas nos locais onde há átomos dopantes. De forma similar, na região com material do tipo $\mathrm{P}$, cargas negativas fixas são criadas. Podemos chamar essas regiões com íons fixos de zonas de cargas espaciais. Entre essas cargas fixas positivas na região $\mathrm{N}$ e as negativas na região $\mathrm{P}$ forma-se um campo elétrico, apontando dos núcleos fixos positivos (região $\mathrm{N}$ ) para os negativos (região $\mathrm{P}$ ), e, consequentemente, se estabelece uma diferença de potencial. Esse espaço, onde atua esse campo, é chamado de zona de depleção (ZD) de cargas. O termo "depleção" é sinônimo de "esvaziamento". Ele reflete a ideia de que o campo elétrico varre as cargas livres para fora dessa região. Cargas negativas livres são varridas para a região $\mathrm{N}$ e cargas positivas livres são varridas para a região $P$.

Células solares são basicamente junções PN de materiais possuindo um gap menor que a energia de uma parte dos fótons da radiação solar. Quando fótons com energia maior do que o gap incidem na junção PN, eles são absorvidos, e pares elétron-buraco são gerados. Tanto os elétrons quanto os buracos produzidos difundem pelo material até que sofram recombinação, captura ou adentrem a ZD e sejam separados pela diferença de potencial. Essa produção de pares e a separação de uma fração deles pela junção PN faz com que aumente o número de elétrons na região $\mathrm{N}$ e de buracos na região $\mathrm{P}$. Com isso, ao se conectar o dispositivo fotovoltaico iluminado a um circuito externo, haverá um fluxo de cargas através desse circuito, fornecendo potência elétrica.

Toda vez que portadores sofrem recombinação ou captura, energia é desperdiçada. Uma forma de minimizar esses efeitos é aumentar a zona de depleção. Dessa forma, os portadores têm maior probabilidade de serem separados e menor probabilidade de sofrerem recombinação ou captura. Para aumentar a ZD basta inserir uma camada de semicondutor intrínseco (não dopado) entre as camadas P e N. Essa estrutura é conhecida como junção PIN [21]. A formação da ZD na junção PIN é análoga a da junção $\mathrm{PN}$, onde o elétron difunde da região $\mathrm{N}$ para a região intrínseca I deixando uma carga positiva para trás. Como não encontra buraco para recombinar, ele viaja até a região $\mathrm{P}$, onde existe um átomo dopante. $\mathrm{O}$ mesmo vale para o buraco que viaja até a região $\mathrm{N}$, deixando para trás uma carga fixa negativa. O resultado é a formação de um campo elétrico por toda a região intrínseca I. O acréscimo dessa região intrínseca aumenta a eficiência da foto célula, pois o aumento da ZD é acompanhado por um aumento da probabilidade de gerar pares elétronburaco nessa região onde ocorre imediata separação do par, diminuindo a perda por recombinação ou captura. Além disso, quanto maior a ZD em relação à espessura da célula, menor a distância que os portadores gerados fora dela precisarão difundir para alcançá-la, diminuindo a probabilidade de perdê-los por recombinação ou captura.

A seguir apresentaremos as equações que descrevem junção PN [39]. 


\subsubsection{Eletrostática da junção PN}

Para entendermos a eletrostática da junção PN, que serve também sem grandes alterações para a junção PIN, e as equações que a descrevem, utilizaremos a Figura 16. Inicialmente, logo antes de serem colocadas em contato, as regiões $\mathrm{P}$ e $\mathrm{N}$ se estendiam até o ponto 0 . Uma vez em contato, após se estabelecer o equilíbrio resultando da difusão dos dois tipos de portadores, aparece uma região de depleção que se estende do ponto $-\mathrm{x}_{\mathrm{p}}$ na região $\mathrm{P}$ até $\mathrm{o}$ ponto $\mathrm{x}_{\mathrm{n}}$ na região $\mathrm{N}$, cujas posições dependem principalmente do nível de dopagem das duas regiões $\mathrm{P}$ e $\mathrm{N}$.
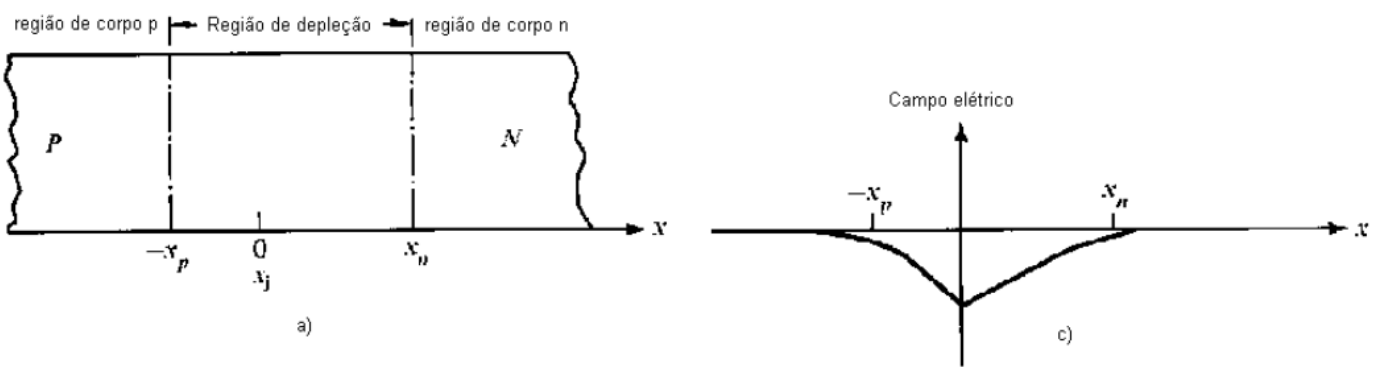

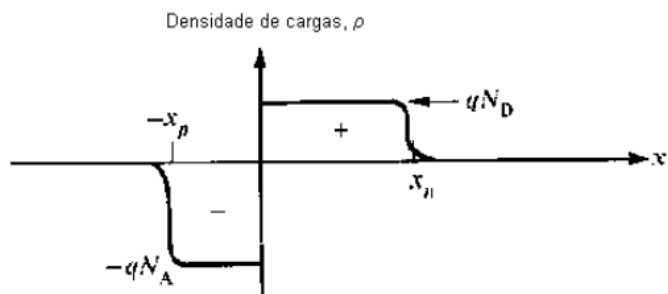

b)

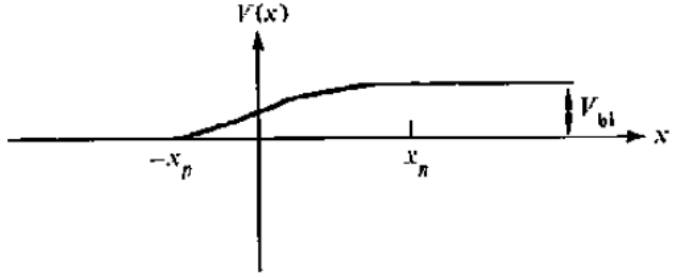

d)

Figura 16: Eletrostática da região de depleção da junção PN mostrando a) as regiões dopadas e de depleção, $b$ ) a distribuição de cargas fixas, c) o valor do campo elétrico interno e d) o valor da tensão interna $V_{b i}$. [39].

Com a equação de Poisson, podemos obter o campo elétrico $\boldsymbol{\varepsilon}$, pois:

$$
\begin{gathered}
\nabla^{2} V=-\frac{\rho}{\varepsilon}=\nabla \cdot(\nabla \mathrm{V})=-\nabla \cdot \varepsilon \\
\nabla \cdot \varepsilon=\frac{\rho}{\varepsilon}
\end{gathered}
$$

Com a equação (2) obtemos o campo integrando a densidade de cargas e levando-se em consideração as condições de contorno, indicadas na Figura 16.b. Como o campo E é o gradiente do potencial, podemos obter o potencial pela integração do campo. Observe que no caso unidimensional em análise:

$$
\varepsilon(x)=\nabla V(x)=-\frac{d V}{d x}
$$

$\mathrm{E}$, adotando $\mathrm{V}(\mathrm{x}=-\infty)=0$ como referência, obtemos:

$$
V(x)=-\int_{x_{1}=-\infty}^{x_{2}} \varepsilon(x) \cdot d x
$$


Com a equação (4) aplicada à Figura 16.c, obtemos o potencial elétrico mostrado na Figura 16.d. Esse é o potencial interno $V_{b i}$ da junção quando está em equilíbrio ${ }^{9}$, que existe mesmo sem a aplicação de uma tensão externa.

\subsubsection{Diagrama de bandas da junção $P N$}

O diagrama de bandas da junção PN (Figura 17) contém informações sobre a distribuição de cargas, do campo elétrico e do potencial elétrico interno da junção $V_{b i}$.

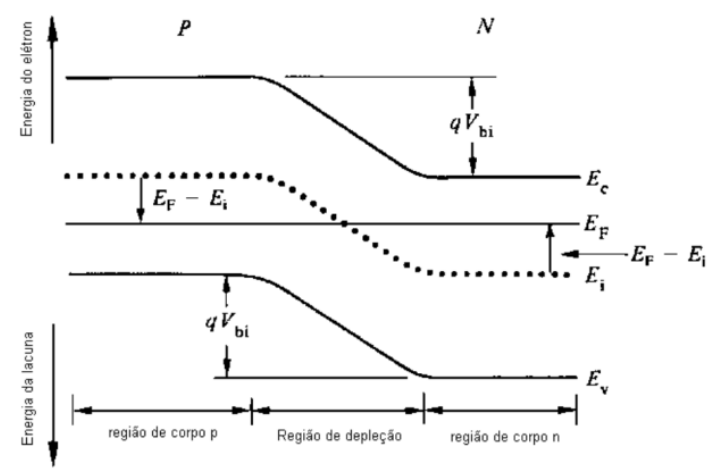

Figura 17: Diagrama de bandas da junção PN em equilíbrio. $E_{F}$ é o nível de Fermi na interface da junção e deve ser constante na estrutura inteira; $E_{i}$ é o nível de Fermi de cada material antes de ser formada a junção; $E_{V}$ é o nível máximo da banda de valência e $E_{C}$ é o nível mínimo da banda de condução.

Podemos obter $V_{b i}$ considerando os níveis de Fermi $\mathrm{E}_{\mathrm{i}}$ de cada material antes de formar a junção, mostrados no diagrama da Figura 17, e observando que:

$$
\begin{gathered}
\Delta \mathrm{V}=-\frac{\Delta \mathrm{E}_{\mathrm{i}}}{q} \\
V_{b i}=-\frac{1}{q}\left[\mathrm{E}_{\mathrm{i}}(\infty)-\mathrm{E}_{\mathrm{i}}(-\infty)\right]
\end{gathered}
$$

O campo elétrico $\boldsymbol{\varepsilon}$ pode ser obtido pelo gradiente de uma das faixas de energia e, em uma dimensão, podemos escrever isso como:

$$
\varepsilon(x)=\frac{1}{q} \frac{d E_{i}}{d x}
$$

A equação (7) e o diagrama da Figura 17 mostram que o campo elétrico $\boldsymbol{\varepsilon}$ é nulo fora da região da ZD. Observe que vemos, na Figura 17, níveis de energia horizontais planos longe da ZD. Dentro da ZD, o campo $\mathcal{E}$ é negativo, concordando com a Figura 16.c. Nessa mesma figura verificamos que há um valor máximo para a magnitude do campo $\boldsymbol{E}$ em $x=0$. Isso corresponde ao valor máximo da derivada de $E_{i}$, como podemos ver na Figura 17. Podemos também encontrar a densidade de cargas, que é obtida pela derivada segunda de um dos níveis do digrama da Figura 17. Podemos reescrever a equação (2) como:

\footnotetext{
${ }^{9} \mathrm{Na}$ bibliografia em inglês utiliza-se o termo built-in potential.
} 


$$
\frac{d \boldsymbol{E}}{d x}=\frac{\rho}{\varepsilon_{S}}
$$

onde $\varepsilon_{S}$ é a constante dielétrica do semicondutor. Das equações (7) e (8), obtemos:

$$
\rho=\frac{\varepsilon_{S}}{q} \frac{d^{2} E_{i}}{d x^{2}}
$$

Podemos constatar das concavidades da curva $E_{i}$ na Figura 17, que é para baixo na região $\mathrm{P}$ e para cima na região $\mathrm{N}$, que teremos na equação (9) um sinal negativo da segunda derivada da curva $E_{i}$ na região $\mathrm{P}$ e um sinal positivo na região N. Portanto, a partir dessas considerações, chegamos à conclusão que há uma densidade de cargas negativas na região $\mathrm{P}$ e uma densidade de cargas positivas na região N. Isso concorda com as observações a partir da Figura 16.

\subsubsection{Cálculo do potencial interno $V_{b i}$ de uma junão PN}

Supondo que o semicondutor não seja degenerado ${ }^{10}$ [39], podemos calcular o potencial interno da junção PN com o uso das relações de Boltzmann. Fazendo uso da Figura 17, podemos escrever para o lado N:

$$
E_{F}-\left.E_{i}\right|_{n}=k T \ln \frac{N_{D}}{n_{i}}
$$

onde $E_{F}$ é o nível de Fermi da junção; $\left.E_{i}\right|_{n}$ é o nível de Fermi do lado N, antes da formação da junção; k é a constante de Boltzmann, T é a temperatura em Kelvin, $n_{i}$ é o número de portadores intrínsecos do material (GaAs no nosso caso, quando ele não é dopado), $N_{D}$ é a concentração dos dopantes doadores (o Si no nosso caso). De forma similar para o lado P, considerando $N_{A}$ a concentração dos dopantes aceitadores (o C no nosso caso) $\left.E_{i}\right|_{p}$ o nível de Fermi do lado P, antes da formação da junção, podemos escrever:

$$
E_{F}-\left.E_{i}\right|_{p}=-k T \ln \frac{N_{A}}{n_{i}}
$$

Das equações (10) e (11), obtemos:

$$
\begin{gathered}
V_{b i}=\frac{1}{q}\left[\left.E_{i}\right|_{p}-\left.E_{i}\right|_{n}\right] \\
V_{b i}=\frac{k T}{q} \ln \frac{N_{D} \cdot N_{A}}{n_{i}^{2}}
\end{gathered}
$$

onde $n_{i}$ é dado pela expressão [40]:

$$
n_{i}=2\left(\frac{k_{B} T}{2 \pi \hbar^{2}}\right)^{3 / 2}\left(m_{e}^{*} m_{h}^{*}\right)^{3 / 4} e^{-\frac{E_{g}}{2 k_{B} T}}
$$

\footnotetext{
${ }^{10}$ Define-se o material como sendo degenerado se o nível de Fermi estiver com distância menor que 3kT da banda de condução ou de valência. Caso contrário, o material é chamado de não degenerado.
} 
onde $\mathrm{k}_{\mathrm{B}}, \mathrm{T}, \mathrm{m}_{\mathrm{e}}{ }^{*}, \mathrm{~m}_{\mathrm{h}}{ }^{*}$ e $\mathrm{E}_{\mathrm{g}}$ são respectivamente a constante de Boltzmann, a temperatura absoluta, a massa efetiva do elétron, a massa efetivo do buraco e a energia do gap do material semicondutor.

\subsubsection{Cálculo da largura $W$ da ZD}

Até agora obtemos uma descrição predominantemente qualitativa da junção PN, obtendo uma expressão quantitativa somente para a tensão interna da junção $V_{b i}$ na equação (13). Falta ainda expressões para calcular as distribuições:

I- do potencial elétrico V;

II- do campo elétrico $\boldsymbol{\varepsilon}$;

III- $\quad$ da densidade cargas $\rho$;

IV- $\quad$ e do tamanho $\boldsymbol{W}$ da ZD.

Para simplificar os cálculos e não precisar recorrer a métodos de cálculo numérico para descrever a variação dos portadores de carga ao longo da ZD, utilizamos o que é conhecido como aproximação de depleção. Essa aproximação descreve muito bem os dados [39] experimentais e considera que a variação da densidade de cargas no material é abrupta nos limites da ZD e na interface entre os materiais $\mathrm{P}$ e N , de modo que, considerando a interface do semicondutor dopado tipo $\mathrm{P}$ e do semicondutor dopado tipo $\mathrm{N}$ como sendo em $x=0$ e os limites da zona de depleção como sendo em $-x_{p}$ e em $x_{n}$, que estão dentro do semicondutor $\mathrm{P}$ e do semicondutor tipo $\mathrm{N}$, respectivamente (Figura 16), temos que:

$$
\rho=\left\{\begin{array}{c}
0, \text { para } x<-x_{p} \\
-q N_{A}, \text { para }-x_{p} \leq x<0 \\
q N_{D}, \text { para } 0 \leq x<x_{n} \\
0, \text { para } x>x_{n}
\end{array}\right.
$$

Portanto, a equação (2) de Poisson se torna:

$$
\frac{d \boldsymbol{E}}{d x}=\left\{\begin{array}{c}
0, \text { para } x<-x_{p} \\
-\frac{q N_{A}}{\varepsilon_{S}}, \text { para }-x_{p} \leq x<0 \\
\frac{q N_{D}}{\varepsilon_{S}}, \text { para } 0 \leq x<x_{n} \\
0, \text { para } x>x_{n}
\end{array}\right.
$$

Onde $\varepsilon_{S}$ é a permissividade elétrica do semicondutor.

Por integração, obtemos:

$$
\boldsymbol{E}=\left\{\begin{array}{c}
\boldsymbol{E}_{\boldsymbol{p}}, \text { para } x<-x_{p} \\
-\frac{q N_{A}}{\varepsilon_{S}}\left(x+x_{p}\right), \text { para }-x_{p} \leq x<0 \\
\frac{q N_{D}}{\varepsilon_{S}}\left(x-x_{n}\right), \text { para } 0 \leq x<x_{n} \\
\boldsymbol{E}_{n}, \text { para } x>x_{n}
\end{array}\right.
$$


sendo que, na ausência de tensão aplicada, as constantes $\boldsymbol{E}_{\boldsymbol{p}}$ e $\boldsymbol{E}_{\boldsymbol{n}}$ se anulam. Como o campo elétrico deve ser contínuo em $x=0$, obtemos da equação (3):

$$
N_{A} \cdot x_{p}=N_{D} \cdot x_{n}
$$

Das equações (3), (4) obtemos o potencial elétrico, considerando o campo elétrico expresso pela equação (17). Adotando o referencial para os referenciais para o potencial como sendo $V\left(x=-x_{p}\right)=0$ e $V\left(x=x_{n}\right)=V_{b i}$, obtemos:

$$
V(x)=\left\{\begin{array}{c}
\frac{q N_{A}}{2 \varepsilon_{S}}\left(x+x_{p}\right)^{2}, \text { para }-x_{p} \leq x<0 \\
-\frac{q N_{D}}{2 \varepsilon_{S}}\left(x-x_{n}\right)^{2}+V_{b i}, \text { para } 0 \leq x<x_{n}
\end{array}\right.
$$

Como tanto o campo elétrico como o potencial devem ser contínuos na interface da junção, temos que:

$$
\frac{q N_{A}}{2 \varepsilon_{S}} x_{p}{ }^{2}=-\frac{q N_{D}}{2 \varepsilon_{S}} x_{n}{ }^{2}+V_{b i}
$$

Das equações (18) e (20), obtemos:

$$
\begin{gathered}
x_{n}=\sqrt{\frac{2 \varepsilon_{S}}{q} V_{b i} \frac{1}{\left(N_{A}+N_{D}\right)} \sqrt{\frac{N_{A}}{N_{D}}}} \\
x_{p}=\sqrt{\frac{2 \varepsilon_{S}}{q} V_{b i} \frac{1}{\left(N_{A}+N_{D}\right)} \sqrt{\frac{N_{D}}{N_{A}}}} \\
W=x_{n}+x_{p}=\sqrt{\frac{2 \varepsilon_{S}}{q} V_{b i}\left(\frac{1}{N_{A}}+\frac{1}{N_{D}}\right)}
\end{gathered}
$$

As equações (21) e (22) descrevem os limites das distribuições de cargas expressas pela equação (15), enquanto que a equação (23) expressa o tamanho da ZD.

\subsubsection{Aplicação de polarização à junção $P N$}

A junção PN pode receber dois tipos de polarização que alteram a sua eletrostática:

I) Polarização direta, quando a tensão $V_{P}$ no lado $\mathrm{P}$ da junção PN é maior que a tensão $V_{N}$ no lado $\mathrm{N}$, ou $V_{P}>V_{N}$;

II) Polarização reversa, quando $V_{P}<V_{N}$; 
Para entender o efeito da polarização sobre uma junção PN, consideremos um circuito completo, no qual é inserida uma junção PN, como mostra a Figura 18.

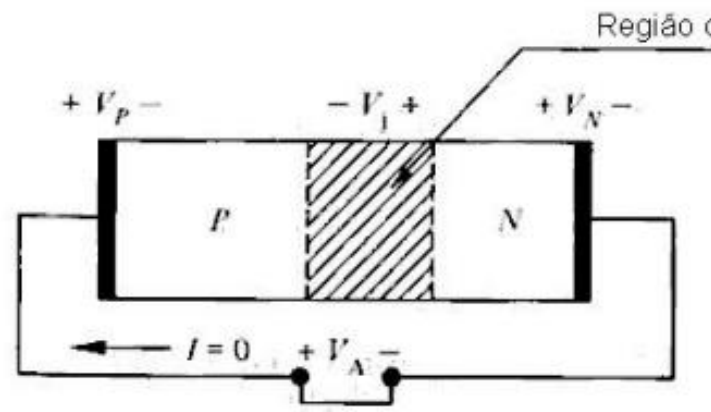

(a) Equilibrio térmico $V_{i}=V_{b i}$

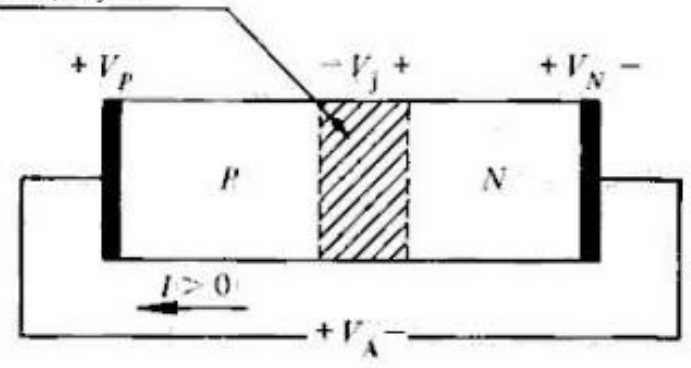

(b) Polarizaçáo direta $V_{A}>0, V_{j}=V_{b i}-V_{A}$

Figura 18: Circuito completo de um diodo a) sem polarização e b) com polarização direta [39].

Observemos primeiro o que ocorre quando não há polarização (Figura 18a), ou seja, quando temos uma tensão aplicada $V_{A}=0$. Nesse caso, a corrente elétrica que flui pelo circuito é nula. Assim não teremos quedas de tensão nas regiões neutras do semicondutor. Já nos contatos ocorrem quedas de tensão $V_{C P}$ e $V_{C N}$ sobre o semicondutor tipo $\mathrm{P}$ e tipo $\mathrm{N}$, repectivamente. $\mathrm{Na}$ ausência de polarização temos ainda que a queda de tensão $V_{J}$ na junção PN é $V_{J}=V_{b i}$. A $2^{\mathrm{a}}$ lei de Kirchhoff nos diz que:

$$
V_{A}-V_{C P}+V_{J}-V_{C N}=0
$$

Portanto:

$$
\left.V_{b i}=V_{C P}+V_{C N}, \quad \text { quando } V_{A}=0 \text { (sem polarização }\right)
$$

Agora, consideremos o caso polarizado (Figura 18b), ou seja, em que aplicamos uma tensão $V_{A}>0$. Se desprezarmos as quedas ôhmicas dentro do próprio semicondutor (que é uma boa aproximação para correntes baixas), a $2^{\mathrm{a}}$ lei de Kirchhoff nos dá:

$$
V_{J}=V_{C P}+V_{C N}-V_{A}, \quad \text { quando } V_{A}>0(\text { polarização direta })
$$

Como os potenciais dos contatos não são alterados pela polarização, as equações (25) e (26) nos fornecem:

$$
V_{J}=V_{b i}-V_{A}, \quad \text { quando } V_{A}>0(\text { polarização direta })
$$

A equação (27) nos diz que a polarização direta faz com que a tensão original da junção diminua. Quando $V_{A}<0$, caso da polarização reversa, a tensão da junção aumenta. Resumindo:

$$
V_{J}=V_{b i}-V_{A}\left\{\begin{array}{c}
V_{A}=0(\text { Polarização nula }) \\
V_{A}>0(\text { Polarização direta }) \\
V_{A}<0(\text { Polarização reversa })
\end{array}\right.
$$


Para encontrar o potencial elétrico V, o campo elétrico $\boldsymbol{E}$, a densidade de cargas $\rho$ e o tamanho $\boldsymbol{W}$ da ZD no caso mais geral onde há polarização, basta substituir o valor da queda de tensão $V_{b i}$ do caso não polarizado, discutido nas equações anteriores, pelo valor de $V_{J}$ aplicado a cada caso.

\subsubsection{Curva IxV da junção PN}

A seguir discutiremos de onde surge a equação que descreve a curva $\mathrm{I} \times \mathrm{V}$ de uma célula solar iluminada. Para isso, precisamos explicar de onde surge a equação de diodo de junção PN, expressa por:

$$
I=I_{0}\left(e^{q V_{A} / k T}-1\right)
$$

\section{Análise qualitativa da curva IxV da junção PN}

\section{i. Em equilíbrio, ou seja, na ausência da polarização

$$
\left(V_{A}=0\right)
$$

Quando a junção está em equilíbrio, ou seja, quando não há tensão externa aplicada, as correntes de difusão e de deriva (aquela que é gerada pela aparição do campo interno e que atua em sentido oposto à de difusão para levar o sistema ao equilíbrio) dos portadores se anulam. Veja que os elétrons e os buracos majoritários, nas regiões formadas por semicondutores tipo $\mathrm{N}$ e tipo $\mathrm{P}$, respectivamente, são repelidos pela barreira de potencial (figura 19) formada pelo campo elétrico da junção $\mathrm{PN}$ de altura $V_{B}=V_{b i}$. Mas há alguns poucos elétrons majoritários com energia acima da energia da barreira $E_{B}=q V_{b i}$ e, por isso, surge uma pequena corrente de difusão que vence a barreira e alcança a região formada pelo semicondutor tipo $\mathrm{P}$, dando origem a uma densidade de corrente de difusão $J_{n(\text { difusão })}$. Os elétrons minoritários, na região formada pelo semicondutor tipo $\mathrm{P}$, que penetram na $\mathrm{ZD}$ da junção $\mathrm{PN}$ são varridos pelo campo elétrico e chegam na região formada pelo semicondutor tipo $\mathrm{N}$, dando origem a uma densidade de corrente de deriva $J_{n(\text { deriva })}$. 


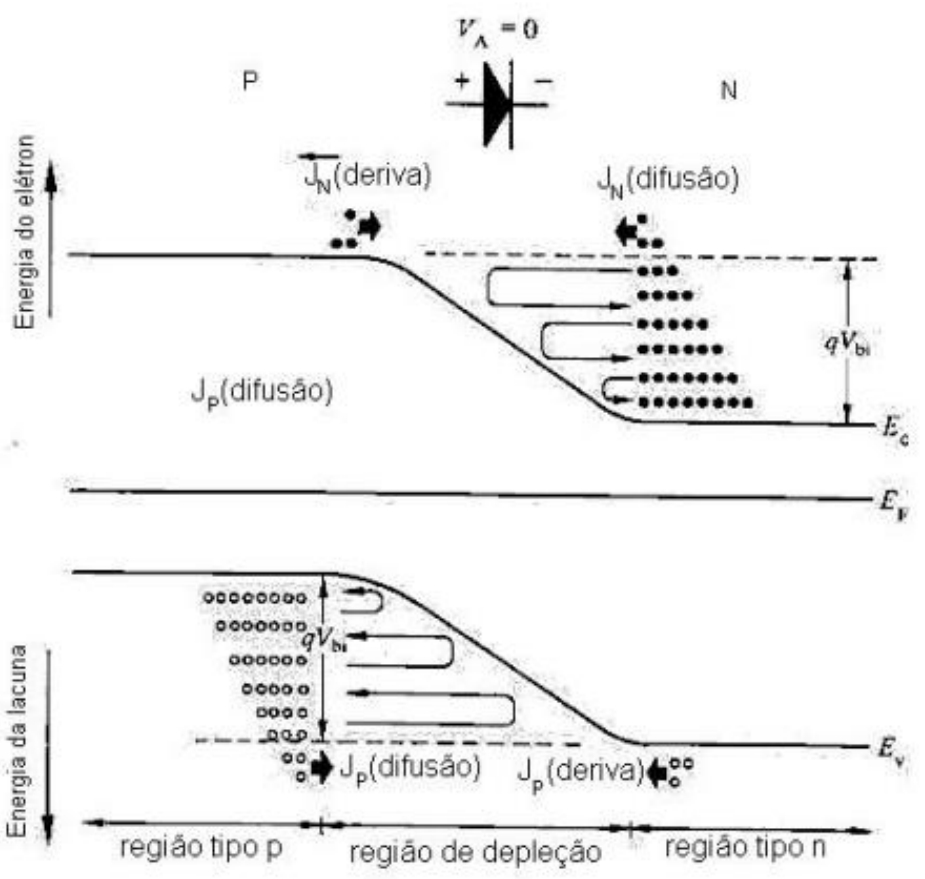

Figura 19: Representação dos níveis de energia de uma junção PN em equilíbrio com a representação dos portadores de carga majoritários e minoritários. Os símbolos dão uma ideia da distribuição dos elétrons (bolinhas) e dos buracos (círculos) no níveis de energia [39].

Essas componentes de corrente se cancelam, de modo que podemos escrever:

$$
J_{n(\text { difusão })}+J_{n(\text { deriva })}=0
$$

onde

$$
J_{n(\text { deriva })}=-q \cdot \mu_{n} \cdot n \cdot \varepsilon
$$

e q é o módulo da carga elementar, $\mu_{n}$ a mobilidade dos portadores negativos no material, e n é a densidade de elétrons. Da mesma forma,

$$
J_{n(\text { difusão })}=q D_{n} \cdot \frac{d n}{d x}
$$

onde $D_{n}$ é a constante de difusão dos elétrons.

O mesmo desenvolvimento feito para os elétrons vale para os buracos. Portanto, para as correntes totais de elétrons e buracos, respectivamente, temos:

$$
\begin{gathered}
-q \cdot \mu_{n} \cdot n+q D_{n} \cdot \frac{d n}{d x}=0 \\
q \cdot \mu_{p} \cdot p-q D_{p} \cdot \frac{d p}{d x}=0
\end{gathered}
$$




\section{ii. Com polarização \\ $\left(V_{A}>0\right)$}

Com a polarização direta, a barreira de potencial diminui de altura (Figura 20a) e o número de elétrons majoritários que passam a ter energia maior que da barreira $V_{B}$ cresce exponencialmente porque os estados de menor energia possuem muito mais elétrons. Por isso, a corrente de difusão aumenta exponencialmente com $V_{A}$. Ao mesmo tempo, devido à diminuição da barreira e da intensidade do campo elétrico, a corrente de deriva diminui. Assim, o mecanismo de difusão passa a predominar (Figura 20b) e há uma injeção de elétrons majoritários através da ZD.

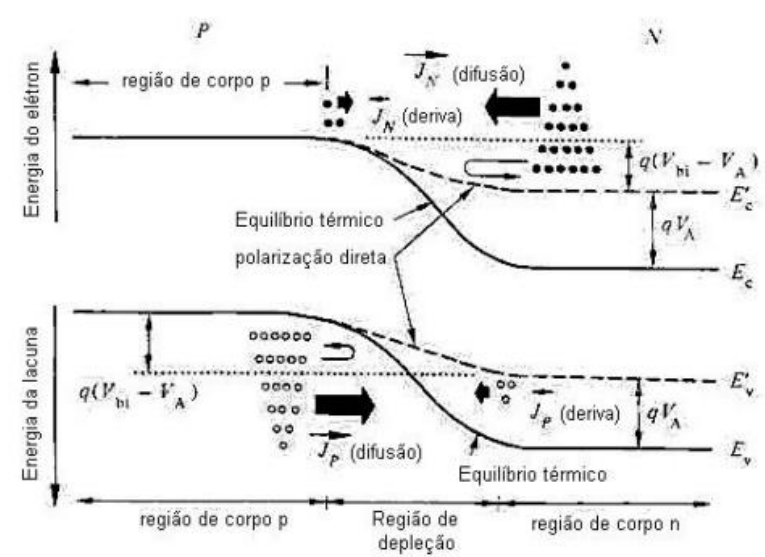

(a)

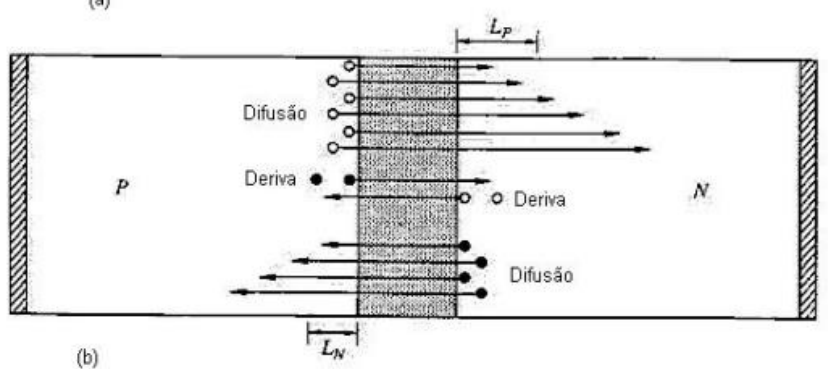

Figura 20: Diagrama de bandas da junção PN sob polarização direta. b) Componentes de corrente que atravessam a $Z D$ quando a junção está sob polarização direta $\left(V_{A}>0\right)$ [39].

Com isso, após passar pela $\mathrm{ZD}$, os elétrons entram na região $\mathrm{P}$ onde passam a ser minoritários e recombinam com os portadores majoritários da região (os buracos), sendo repostos pelo contato externo, dando continuidade à corrente (Figura 21).

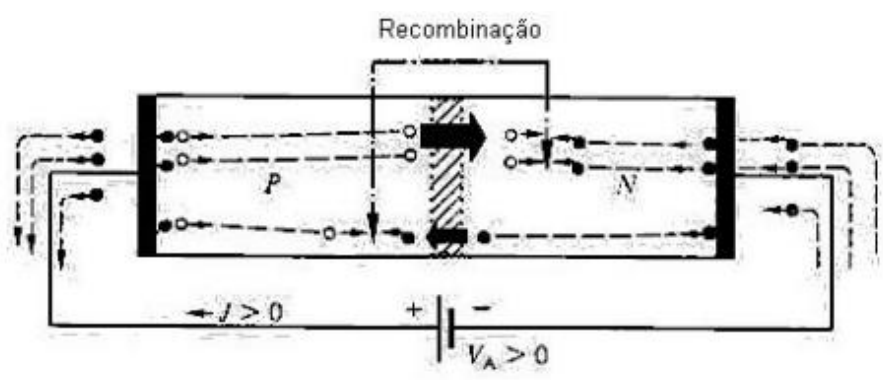

Figura 21: Fluxo de portadores em um circuito com a junção $P N$ sob polarização direta $\left(V_{A}>0\right)$ [39]. 


\section{iii. Com polarização reversa \\ $\left(V_{A}<0\right)$}

Com a polarização reversa, a barreira de potencial aumenta de altura (Figura 22a) e o número de elétrons majoritários que passam a ter energia maior que da barreira $V_{B}$ diminui exponencialmente. Como o campo elétrico passa a ser mais intenso, o número de elétrons que atravessam a ZD praticamente zera. Mas o mecanismo de deriva continua a funcionar, pois depende apenas dos portadores, na borda da ZD, serem capturados por ela (Figura 22b). Como o número desses portadores baixou bastante com a polarização reversa, a corrente de deriva é pequena e constante. A deriva dos portadores minoritários faz com que a concentração dos portadores minoritários na borda da ZD diminua abaixo de uma concentração de equilíbrio.
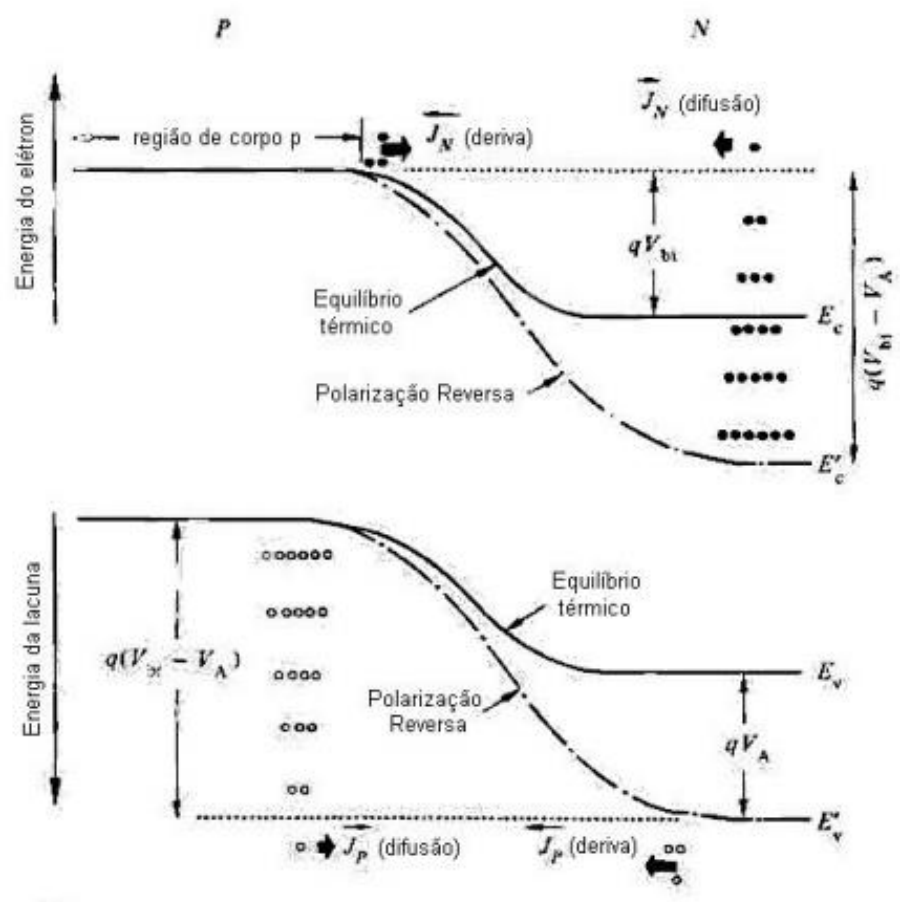

(a)

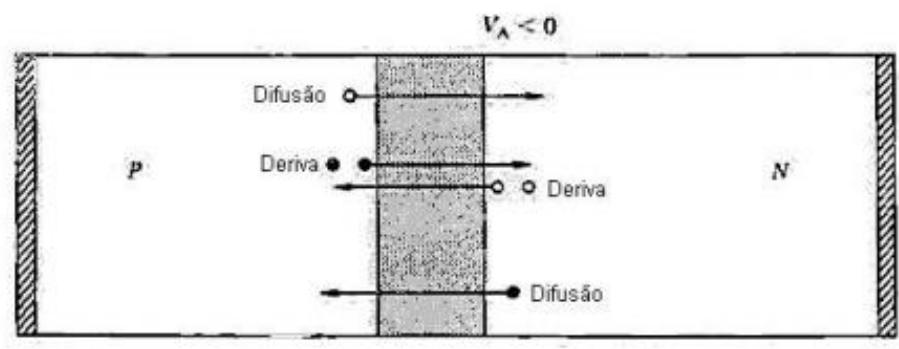

(b)

Figura 22: Diagrama de bandas da junção PN sob polarização reversa. b) Componentes de corrente que atravessam a ZD quando a junção está sob polarização reversa $\left(V_{A}<0\right)$ [39].

Esses portadores são repostos na borda da ZD através dos processos de geração térmica e difusão, dentro da região neutra, fora da $\mathrm{ZD}$, dando continuidade à corrente de deriva. Após 
atravessar a ZD, os portadores minoritários que constituem a corrente de deriva passam a ser majoritários. Os processos de geração e difusão que repõem os portadores minoritários nas bordas da ZD são alimentados pelo fluxo de portadores majoritários vindos dos contatos externos (Figura 23). Novamente, deveremos ter a recombinação de buracos com elétrons no contato do metal com o semicondutor tipo $\mathrm{P}$, como no caso de polarização direta.

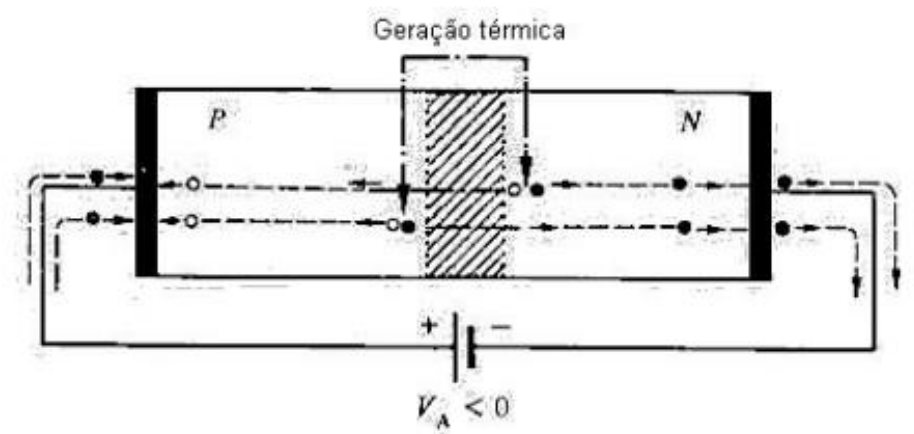

Figura 23: Fluxo de portadores em um circuito com a junção $P N$ sob polarização reversa $\left(V_{A}<0\right)$ [39].

\section{Análise quantitativa da curva $\mathrm{I} \times \mathrm{V}$ de uma CS de junção PN}

Para descrever a curva I $\times \mathrm{V}$ característica de uma célula solar (Figura 24), observemos que nosso trabalho se resume a descrever a origem da equação característica da curva $I \times V$ de um diodo de junção $\mathrm{PN}$ no escuro, uma vez que a curva $\mathrm{I} \times \mathrm{V}$ da CS iluminada é o resultado da curva $I_{p h} \times V$ resultante da iluminação (de valor constante $\mathrm{I}_{\mathrm{ph}}=\mathrm{I}_{\mathrm{L}}$ ) diminuída da curva $I_{D} \times V$ do diodo de junção PN no escuro. Ou seja:

$$
I=I_{L}-I_{D}
$$

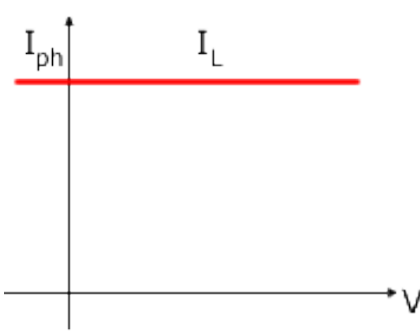

$$
I_{p h}=I_{L}
$$
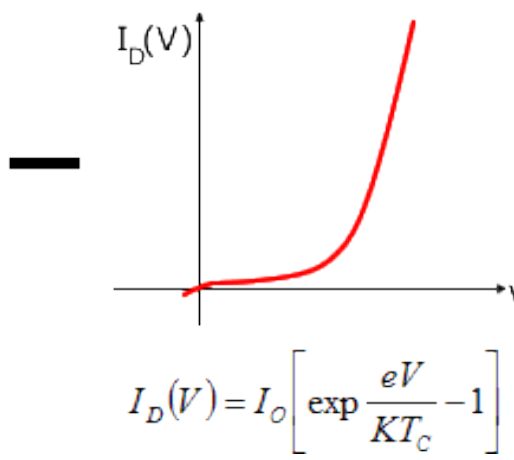

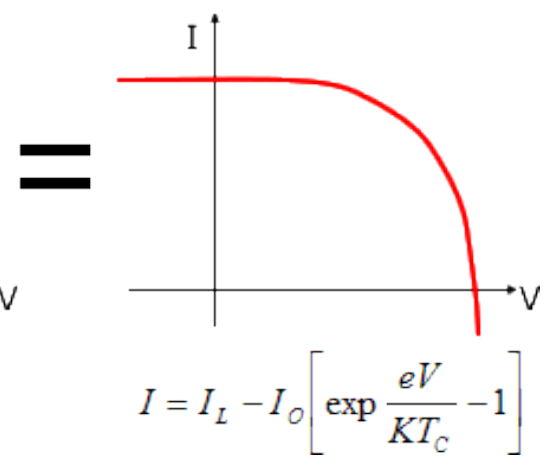

Figura 24: Curva I×V de uma célula solar [41].

Para efetuar a derivação da curva $I_{D} \times V$, precisamos de condições de contorno para resolver as equações diferenciais de difusão dos portadores de carga minoritários não regiões neutras fora da zona de depleção. Nas bordas $-x_{p}$ e $x_{n}$ da região de depleção, temos as seguintes condições de contorno para a concentração dos portadores minoritários $n_{p}$ (densidade de elétrons 
$n$ na região com semicondutor tipo $\mathrm{P}$ ) e $p_{n}$ (densidade de buracos $p$ na região com semicondutor tipo N:

$$
\begin{gathered}
n_{p}\left(-x_{p}\right)=n_{p 0} \cdot e^{q V_{A} / k T} \\
p_{n}\left(x_{n}\right)=p_{n 0} \cdot e^{q V_{A} / k T}
\end{gathered}
$$

onde $n_{p 0}$ são $p_{n 0}$ são a concentração de portadores na ausência de polarização, ou seja, quando $V_{A}=0$. Um dos argumentos da literatura para o uso dessa condição de contorno é simplesmente de que é uma lei da junção ${ }^{11}$. Essa afirmação é devida à boa concordância do modelo, desenvolvido baseado nessa condição, com a característica experimental da junção [39]. A Figura 25 mostra o caso em que a polarização é direta, ou seja, $V_{A}>0$ :
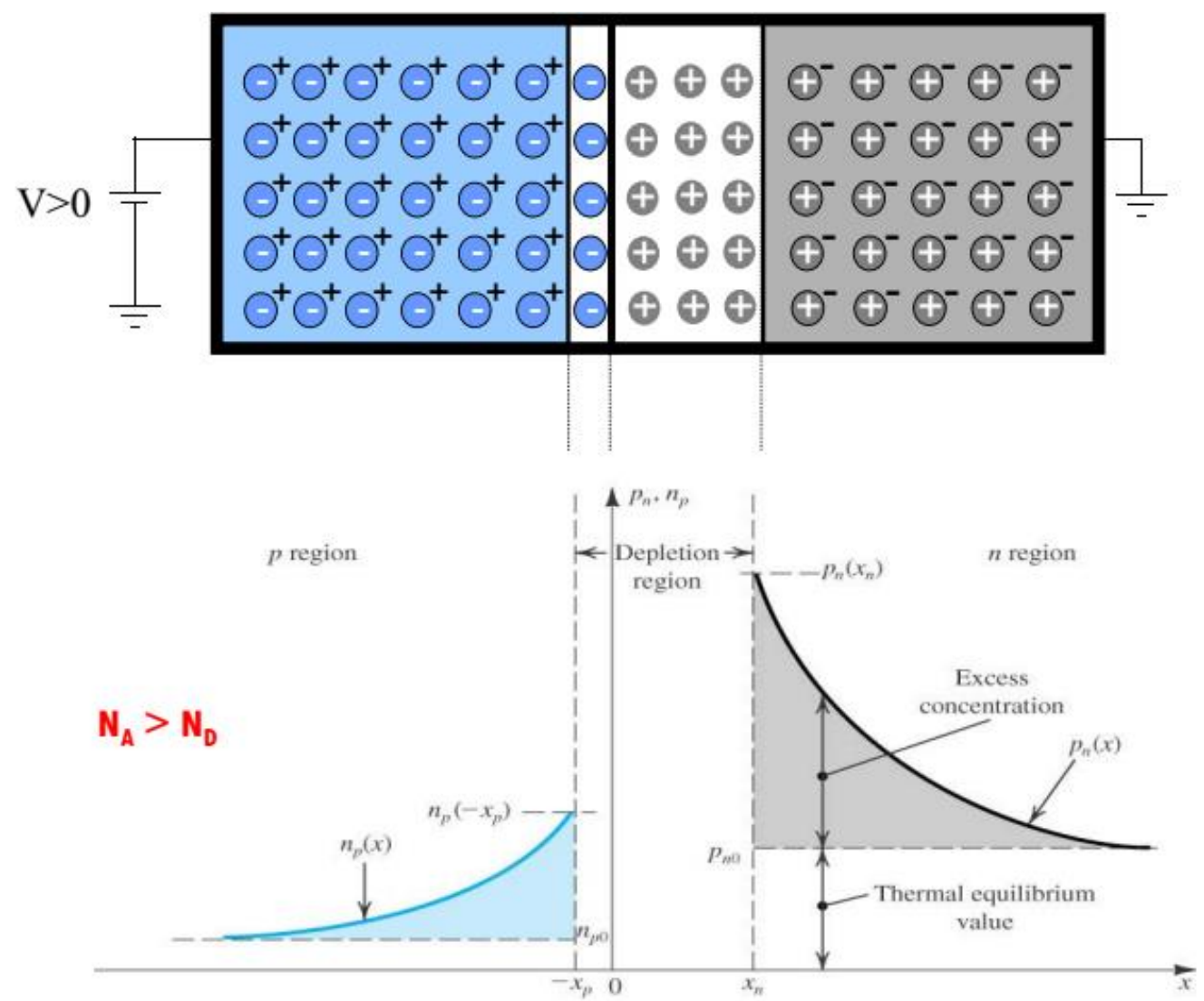

Figura 25: Junção PN polarizada diretamente, ou seja, com $V_{A}>0$ [42].

Veja que podemos expressar a concentração dos portadores minoritários $n_{p}(x)$ e $p_{n}(x)$, obedecendo às equações de contorno (35) e (36), da seguinte forma:

$$
p_{n}(x)=p_{n 0}+\left[p_{n}\left(x_{n}\right)-p_{n 0}\right] e^{-\left(x-x_{n}\right) / L_{p}}
$$

${ }^{11}$ Jacobus W. Swart - Materiais Elétricos - Cap.10 - p.- 36 
onde $L_{p}=\sqrt{D_{p} \tau}$ é o comprimento de difusão e ajusta a taxa de queda da exponencial. $D_{p}$ é a constante de difusão e $\tau$ é o tempo de vida dos portadores minoritários positivos. Note que a equação (37) é uma exponencial com valor inicial em $x=x_{n}$ de $p_{n}\left(x_{n}\right)$ e de valor final em $x=$ $\infty$ de $p_{n}(\infty)=p_{n 0}$. As equações de difusão dos portadores [39] [43] minoritários positivos no semicondutor tipo $\mathrm{N}$ são dadas:

$$
J_{p}=-q D_{p} \frac{d p_{n}(x)}{d x}
$$

Podemos obter a corrente de difusão utilizando a equação (37) e (38). Veja que:

$$
\frac{d p_{n}(x)}{d x}=-\frac{q}{L_{p}}\left[p_{n}\left(x_{n}\right)-p_{n 0}\right] e^{-\left(x-x_{n}\right) / L_{p}}
$$

E portanto:

$$
J_{p}=D_{p} \frac{q}{L_{p}}\left[p_{n}\left(x_{n}\right)-p_{n 0}\right] e^{-\left(x-x_{n}\right) / L_{p}}
$$

Fazendo uso da equação de contorno (35), obtemos:

$$
J_{p}=\frac{D_{p} q}{L_{p}} p_{n 0}\left[e^{q V_{A} / k T-1}\right] e^{-\left(x-x_{n}\right) / L_{p}}
$$

Em $x=x_{n}$, temos:

$$
J_{p}=\frac{D_{p} q}{L_{p}} p_{n 0}\left[e^{q V_{A} / k T-1}\right]
$$

Realizando o mesmo raciocínio para obtermos a corrente em $x=-x_{p}$ devido aos portadores minoritários negativos no semicondutor tipo $\mathrm{p}$ e somando essas duas parcelas, chegamos à seguinte expressão para a corrente total através da ZD:

$$
J=q\left[\frac{D_{n}}{L_{n}} n_{p 0}+\frac{D_{p}}{L_{p}} p_{n 0}\right]\left(e^{q V_{A} / k T}-1\right)
$$

Se multiplicarmos a equação (43) pela área $A$ da interface da junção PN, obtemos a corrente:

$$
I=I_{0}\left(e^{q V_{A} / k T}-1\right)
$$


onde

$$
I_{0}=q A\left[\frac{D_{n}}{L_{n}} n_{p 0}+\frac{D_{p}}{L_{p}} p_{n 0}\right]
$$

Com a equação (44), podemos traçar uma curva IxV característica do modelo de diodo (Figura 26) no escuro que evidencia o caráter retificador, permitindo a passagem de corrente com polarização direta com dependência exponencial e bloqueando a corrente durante a polarização reversa.

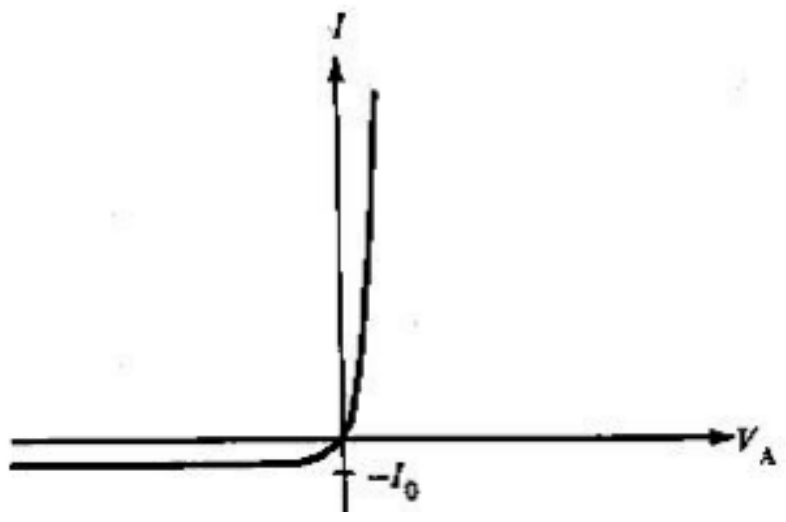

Figura 26: Curva $I \times V$ de um diodo, evidenciando o caráter retificador [39].

\section{Adaptações ao caso real}

Apesar de a equação (44) ajudar a descrever a maior parte dos aspectos físicos da curva IxV da célula solar iluminada, que pode ser expressada pela equação (46), ainda são necessárias algumas adaptações para descrever dispositivos reais.

$$
I=I_{L}-I_{0}\left(e^{q V_{L} / k T}-1\right)
$$

Para isso, a literatura tem utilizado uma combinação de diodos com parâmetros ajustáveis, além de um fator de corrente de fuga $I_{s h}$ de modo que a equação (44) se torna:

$$
I=I_{L}-\sum_{i=1}^{N} I_{0_{i}}\left(e^{q V_{L} / m_{i} k_{B} T}-1\right)-I_{S h}
$$

onde $V_{L}$ é a tensão gerada pela CS quando é iluminada., nesse caso, $m_{i}$ é o fator de idealidade e serve para ajustar a curva $I$ de acordo com o modelo que queremos utilizar para descrever a sua forma. De acordo com a figura $27, I_{s h}$ pode ser expresso por:

$$
I_{s h}=\frac{V-I R_{S}}{R_{s h}}
$$




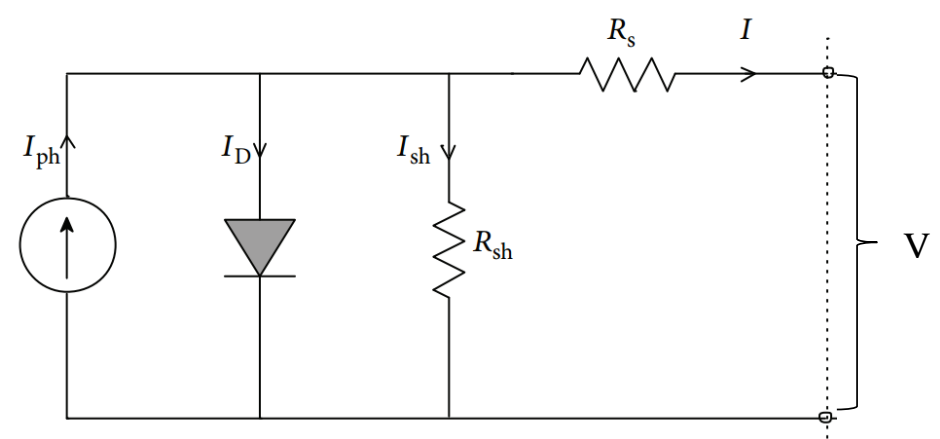

Figura 27: Esquema de uma célula solar real iluminada onde constam a corrente fotogerada $I_{P h}$, a corrente de diodo no escuro $I_{D}$, a corrente de fuga (shunt) $I_{\text {sh }}$, a corrente fornecida ao circuito externo $I$, as resistências de shunt $R_{\text {sh }} e$ de série $R_{S}$ e a queda de tensão $V$ medida nos contatos elétricos da célula.

A corrente de shunt corresponde a uma corrente de fuga através do dispositivo, por isso deve ser o mais baixa possível. Portanto, devemos ter a maior resistência de shunt $R_{s h}$ possível. A resistência em série representa a dificuldade da corrente em atravessar o dispositivo e (principalmente) os contatos para chegar até o circuito externo. Portanto, o ideal é que seja a menor possível. A maioria dos trabalhos utiliza o modelo de diodo simples expresso por:

I) CS iluminada

$$
I=I_{L}-I_{0}\left[e^{\frac{q\left(V+I R_{S}\right)}{n k T}}-1\right]-\frac{V+I R_{S}}{R_{s h}}
$$

onde $\mathrm{V}$ é a tensão medida entre os contatos da CS, quando é iluminada, e que pode ser transmitida a um circuito externo, pois temos $V_{L}=I R_{S}+I V$.

II) CS no escuro

$$
I_{D}=I_{0}\left[e^{\frac{q\left(V_{A}-I R_{S}\right)}{n k T}}-1\right]+\frac{V_{A}-I R_{S}}{R_{S h}}
$$

onde $V_{A}$ é a tensão aplicada na CS no escuro para que possamos encontrar os parâmetros $I_{0}$ e n.

Mas podemos encontrar também vários trabalhos que utilizam a modelagem com 2 ou 3 diodos, dependendo da aplicação ou quando se deseja explicar comportamentos da curva I $\times \mathrm{V}$ que não podem ser satisfatoriamente explicados com um número menor de diodos. Nesse trabalho, optamos por utilizar a análise das curvas IxV pelo modelo de um único diodo, expresso pela equação (49) por ele ser mais fácil e largamente adotado nas referências utilizadas.

\section{Simplificações e interpretações da curva IxV}

Vários métodos têm sido desenvolvidos para o cálculo dos fatores n e $\mathrm{I}_{0}$ [44] [45] [46] [47] da equação (49). Um dos métodos mais simples é a plotagem de um gráfico do logaritmo da corrente em função da tensão aplicada nos contatos da fotocélula mantida no escuro. Se 
considerarmos uma fotocélula no escuro $\left(I_{L}=0\right)$ e assumirmos $R_{\text {sh }}$ grande, a equação (49) resulta em:

$$
I=0-I_{0}\left(e^{\frac{q V}{n k T}}-1\right)-0
$$

Aplicando o logaritmo na equação (51), temos:

$$
\log I=\log I_{0}+\log \left(e^{\frac{q V}{n k T}}-1\right)
$$

$\mathrm{Na}$ equação (52) podemos desprezar o termo -1 para valores suficientemente altos da tensão aplicada. Para que tenhamos uma estimativa dos valores de tensão necessários para isso, façamos a seguinte análise: consideremos que $\mathrm{n}$ é da ordem de 1 , que T é da ordem de $300 \mathrm{~K}$. Para que possamos desprezar o termo -1, devemos ter, então:

$$
e^{\frac{q V}{n k T}} \gg 1
$$

Ou seja:

$$
\begin{gathered}
\frac{q V}{n k T} \gg 1 \\
V \gg \frac{300}{1,160 \cdot 10^{4}}[V] \cong 0,026[V]
\end{gathered}
$$

Se tivermos o cuidado com a condição descrita pela equação (55), o que é geralmente o caso neste trabalho, visto que $\mathrm{V}_{\mathrm{OC}}$ para células de GaAs é da ordem de $1 \mathrm{~V}$, a equação (52) poderá ser escrita como:

$$
\log I=\log I_{0}+\frac{q V}{n k T}
$$

Ou seja, em um gráfico do logaritmo da corrente em função da tensão aplicada nos contatos da fotocélula, no escuro, teríamos uma reta cujo intercepto com o eixo das ordenadas nos daria o valor de $\log I_{0}$ e o coeficiente angular nos daria o valor de $\frac{q}{n k T}$. Como todos os valores são conhecidos, exceto n, poderíamos obtê-lo facilmente. No entanto, apesar dessa análise ser bastante útil para que possamos avaliar as nossas fotocélulas, na literatura é apontado que o fator de idealidade depende bastante tanto das recombinações não ideais na RCE como das resistências $\mathrm{R}_{\mathrm{S}}$ e $\mathrm{R}_{\mathrm{sh}}$. Na Figura 28 podemos ver a dependência teórica do fator de idealidade $\mathrm{n}$ com a tensão, em uma célula solar ideal e em uma célula solar com resistências $R_{S}$ e $R_{s h}$ [44] [48] [49]. 


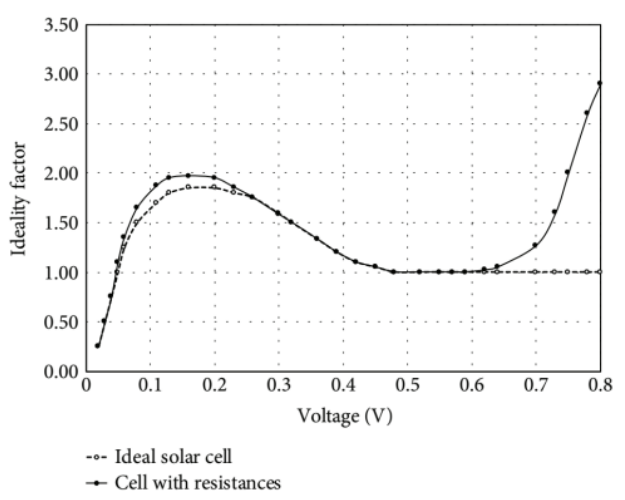

Figura 28: Dependência do fator de idealidade $n$ do modelo de um diodo com a voltagem gerada na junção pela luz. numa célula solar típica de Si. Para o caso real, usamos $R_{S}=0,100 \Omega . \mathrm{cm}^{2}, R_{s h}=1,00 \mathrm{M} . \mathrm{cm}^{2}, I 0=1,00 \times 10^{-13} \mathrm{~A} / \mathrm{cm}^{2}$ [44].

Através da Figura 28 verificamos que os valores do fator de idealidade variam de acordo com intensidade da tensão de polarização aplicada ao modelo. Podemos ver que, caso aplicássemos uma tensão de polarização direta muito alta, o fator de idealidade cresceria rapidamente. Além disso, o fator de idealidade pode indicar a origem e o tipo de recombinação. Os fatores de idealidade e os valores de corrente de escuro são parâmetro de extrema importância e que ajudam a ajustar os modelos de diodos ideais para os casos reais dentro dos limites de operação das células solares.

\subsection{Figuras de mérito}

Para podermos comparar as nossas células solares com as diversas células solares produzidas ao redor do mundo, precisamos de algumas figuras de mérito que são comumente utilizadas na caracterização das células solares pela comunidade científica. Algumas dessas figuras de mérito como o fator de idealidade e a corrente de escuro já foram mencionadas nos tópicos anteriores. Na Figura 29 são mostradas mais algumas figuras de mérito que são comumente utilizadas pela comunidade científica.

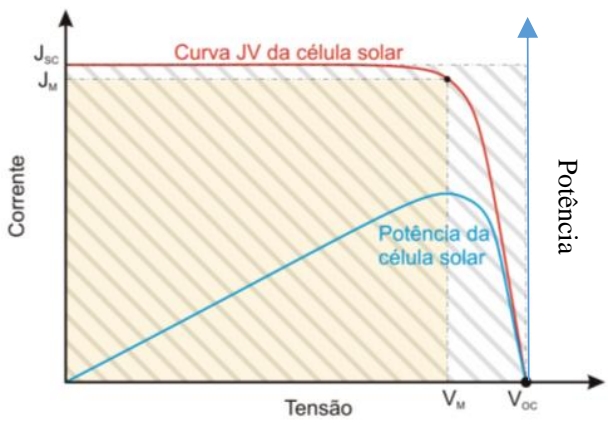

Figura 29: Curva característica de uma célula solar iluminada com os principais parâmetros [50].

A corrente de curto circuito $I_{S C}$ é a corrente que passa na CS quando está encurto circuito, ou seja, com tensão nula. 
A tensão de circuito aberto $V_{O C}$ é a queda de tensão entre os terminais do dispositivo quando a densidade de corrente que passa na CS é nula, ou seja, quando o dispositivo não está ligado a uma carga.

É obvio que queremos uma célula que gere a maior potência possível $P_{\text {Máx }}$ com uma dada potência luminosa $P_{i n}$. Assim, a figura de mérito mais importante na caracterização de uma célula solar é a eficiência $\eta$, definida como:

$$
\eta=\frac{P_{M a ́ x}}{P_{\text {in }}}
$$

Podemos pensar, observando a Figura 29, que teríamos a melhor eficiência $\eta$ para os maiores valores $I_{S C}$ e $V_{O C}$. Mas só isso não é o suficiente, apesar de ser necessário. Além disso, é necessário que a curva $\mathrm{I} \times \mathrm{V}$ da Figura 29 seja o mais retangular possível, delimitando, no caso ideal a mesma área delimitada pelo retângulo de área $A=I_{S C} \cdot V_{O C}$. A medida que expressa $\mathrm{o}$ quão próximo a curva $\mathrm{I} \times \mathrm{V}$ está do caso ideal é o fator de preenchimento $\left(F F^{12}\right)$, expresso por:

$$
F F=\frac{P_{M}}{I_{S C} \cdot V_{O C}}
$$

Em termos dos pontos de corrente e tensão de máxima potência, $I_{M}$ e $V_{M}$, respectivamente, a equação (58) pode ser escrita como:

$$
F F=\frac{I_{M} \cdot V_{M}}{I_{S C} \cdot V_{O C}}
$$

Assim, a equação (57) da eficiência pode ser expressa em temos do FF, $I_{S C}$ e $V_{O C}$ da seguinte forma:

$$
\eta=\frac{F F \cdot I_{S C} \cdot V_{O C}}{P_{\text {in }}}
$$

Assim, caso obtenhamos uma eficiência baixa, podemos ter uma ideia de qual a origem do problema (se $I_{S C}$ ou $V_{O C}$ estão baixos, ou se as resistências são não ideais e consequentemente temos um FF baixo) e pensar em estratégias para melhorar essas figuras de mérito. Além disso, podemos estimar as resistências em série e de shunt, observando a curva $\mathrm{I} \times \mathrm{V}$ da Figura 29, já que esses 2 parâmetros são inversamente proporcionais ao coeficiente angular da curva $I \times V$ nos pontos $\mathrm{V}_{\mathrm{OC}}$ e $\mathrm{I}_{\mathrm{SC}}$, respectivamente [50], o que significa que a curva $\mathrm{I} \times \mathrm{V}$ deve ficar o mais horizontal possível perto de $\mathrm{I}_{\mathrm{SC}}$ e o mais vertical possível perto de $\mathrm{V}_{\mathrm{OC}}$.

\subsection{Interface metal-semicondutor}

Todos os dispositivos precisam de conexões elétricas para operarem. Essa conexão consiste normalmente num fio condutor que é colado ou soldado sobre o dispositivo. Para que isso seja feito em boas condições, costuma-se depositar, nas regiões do dispositivo, onde serão

${ }^{12} \mathrm{FF}$, do inglês fill factor. 
realizadas essas conexões, um fino filme metálico sobre o qual será realizada a solda. Cada tipo de dispositivo e material requer geralmente metais específicos para otimizar a qualidade da conexão. A Barreira Schottky (SB) $\Phi_{B}$ é uma barreira de potencial, formada em junções metalsemicondutor (MS), que surge devido à descontinuidade dos estados de energia responsáveis pela condução elétrica. O esquema dessa descontinuidade pode ser visto na Figura 30. Essa barreira faz com que o contato elétrico não seja ôhmico, pois, devido à presença dessa barreira, ocorre uma não linearidade no fluxo de corrente quando uma tensão externa é aplicada [51]. O comportamento das bandas de energia nas proximidades da interface MS e o mecanismo de formação da SB tem sido uma área de pesquisa muito ativa em Física de Matéria Condensada e Ciência de Superfícies nos últimos 60 anos. Apesar da vasta quantidade de conhecimento desenvolvido nestas pesquisas, ainda hoje é muito difícil descrever a SB do ponto de vista prático, pois tal descrição depende das peculiaridades físico-químicas da interface MS. Discutiremos rapidamente agora como se dá essa descrição e quais são suas limitações práticas [51] [52].

O diagrama da Figura 30 mostra as bandas de níveis de energia para um metal, à esquerda, e para um semicondutor tipo $\mathrm{N}$, à direita, no momento do contato entre eles e logo antes que seja estabelecido o equilíbrio.

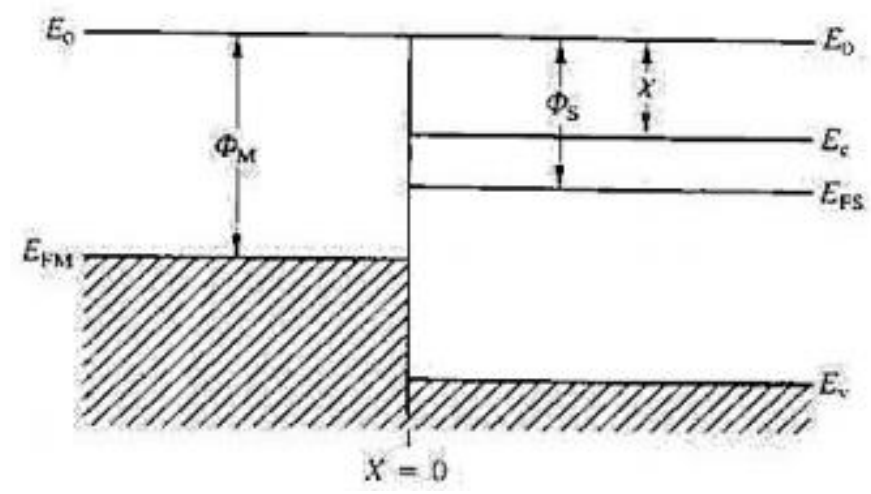

Figura 30: Diagrama de bandas de energia para o metal, à esquerda, e para um semicondutor dopado do tipo $N$, à direita, no momento do contato e logo antes do estabelecimento do equilíbrio. $E_{0}$ é o nível de energia do vácuo, no qual o elétron está livre fora do material. $\Phi_{M}$ é a função trabalho do metal. No semicondutor, $\Phi_{S}$ é a função trabalho; $E_{C}$ é o mínimo da banda de condução; $E_{V}$ é o máximo da banda de valência; $E_{F S}$ é o nível de Fermi para o semicondutor dopado; $X$ é a afinidade eletrônica do semicondutor [39].

No metal, à esquerda da Figura 30, os estados eletrônicos deslocalizados em torno do nível de Fermi são os responsáveis pela condução e não se acoplam com nenhum estado eletrônico do semicondutor à direita, ou seja, ficam no meio do gap do semicondutor, o que dificulta a passagem dos elétrons (e, portanto, da corrente elétrica) da esquerda para a direita. No semicondutor, do lado direito, os elétrons que possuem uma energia $\mathrm{E}_{\mathrm{C}}$ estão com uma energia $e \cdot\left(\Phi_{S}-\chi\right)$, acima do nível de Fermi $E_{F S}$. Essa diferença de energia contribui para retificar a corrente de tal forma que seja mais fácil que os elétrons fluam do semicondutor para o metal do que no caso contrário. De forma análoga, é mais fácil que os buracos fluam do semicondutor para o metal. Essa corrente depende exponencialmente da magnitude dessa barreira e possui um grande impacto na eficiência dos dispositivos. Por isso, é de extrema importância entender como diminuíla [51]. O que define se são os elétrons da banda de condução ou se são os buracos da banda de valência os responsáveis pela condução de corrente é o tipo de dopagem. Para semicondutores do tipo $\mathrm{N}$, os elétrons nos estados próximos a $\mathrm{E}_{\mathrm{C}}$ são os principais responsáveis pela condução, e para semicondutores do tipo $\mathrm{P}$, os buracos nos estados próximos a $\mathrm{E}_{\mathrm{V}}$ são os principais responsáveis [51]. 
Visto que geralmente os níveis de Fermi dos 2 materiais que formam a junção MS são diferentes, quando os dois materiais são colocados em contato, existe uma transferência de cargas de um lado para o outro até que o nível de Fermi seja o mesmo em todos os lugares do novo sistema. Isso faz com que, na interface entre os 2 materiais, haja uma curvatura das bandas dos semicondutor que dará a exata dimensão (altura e largura) da barreira Shottky formada [53] [54] [39], como é mostrado na Figura 31 para o caso da interface MS tipo N (MS-N $\left.{ }^{13}\right)$.

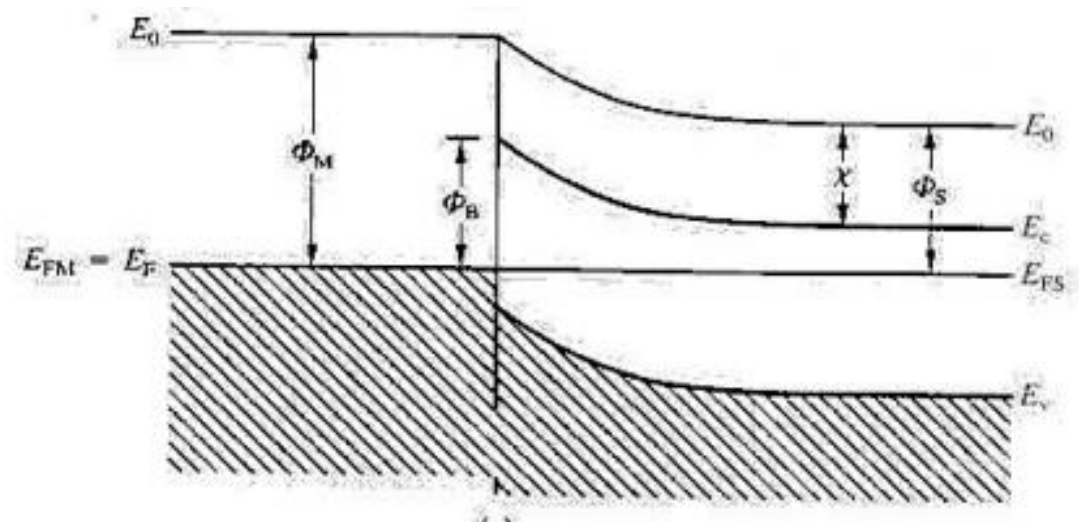

(c)

Figura 31: Curvatura das bandas do semicondutor na interface como metal e formação da Barreira Schottky de altura $\Phi_{B}$ na junção MS-N [39].

Na Figura 31, para chegar à interface MS, os elétrons, no semicondutor, encontram uma barreira de potencial de altura:

$$
\Phi_{M}-\Phi_{S}
$$

Os elétrons do metal encontram uma barreira de potencial, na interface MS, de altura $\Phi_{B}$ :

$$
\Phi_{B}=\Phi_{M}-X
$$

As bandas de condução e de valência vão ser curvadas para cima ou para baixo (Figura 31) dependendo das relações entre as funções trabalho do metal e do semicondutor. Se $\Phi_{M}>\Phi_{S}$ a curvatura será para cima e a junção será retificadora, o que significa que a corrente elétrica terá problema para passar do metal para o semicondutor e a curva corrente-voltagem (IV) será não linear. Se $\Phi_{M}<\Phi_{S}$, a curvatura será para baixo e a junção será ôhmica. A junção MS também será ôhmica quando a BS for suficientemente baixa. Portanto, temos que escolher cuidadosamente os metais que serão depositados sobre o semicondutor de tal forma que as funções trabalho de cada lado da junção sejam parecidas e que o contato seja ôhmico.

\subsection{Mecanismos de perda}

Como discutido anteriormente, o processo de absorção da radiação pela célula solar se dá através da promoção de um elétron da banda de valência para a banda de condução. Contudo, uma vez na banda de condução, os elétrons podem perder parte ou até mesmo toda a energia que

13 MS-N é a interface metal semicondutor tipo N, ou seja, quando o semicondutor que forma uma junção com o metal é dopado de modo a aumentar seu número de elétrons. 
haviam absorvido. Os mecanismos responsáveis por essa perda são a termalização, a recombinação - radiativa, Schockley-Read-Hall (SRH) ou Auger [55] - e a captura em um estado metaestável [44].

$\mathrm{Na}$ termalização ocorre a perda de energia através da geração de fônons que fazem a estrutura do material vibrar e aquecer.

Na recombinação SRH, um elétron cai num nível de energia criado no meio do gap e, através desse estado, recombina com um buraco. Esse nível dentro do gap se deve a algum defeito na estrutura cristalina. Portanto, para que a recombinação SRH seja minimizada é necessário que se utilize semicondutores cristalinos com a menor densidade de defeitos possível. Notoriamente, técnicas de deposição que possibilitem a criação de filmes finos cristalinos de alta qualidade, como a MOVPE (Metal Organic Vapour Phase Epitaxy) [55] e a MBE (Molecular Beam Epitaxy) [56], tendem a produzir células solares com menos recombinação SRH e, consequentemente, maior eficiência. Esse tipo de recombinação depende fortemente da qualidade do material.

Na recombinação radiativa um elétron da banda de condução recombina diretamente com um buraco da banda de valência reemitindo energia na forma de um fóton.

Na recombinação Auger, um elétron recombina com um buraco e a energia liberada, em vez de ser na forma de um fóton, é transferida para um outro elétron (chamado elétron Auger) da banda de condução [57].

Nos semicondutores de gap direto, como é o caso do GaAs, o mecanismo de perda mais relevante é geralmente a recombinação radiativa, enquanto que nos semicondutores de gap indireto, como o $\mathrm{Si}$, as recombinações Auger e SRH dominam.

\subsection{Radiação solar e espectro solar padrão}

Para que se possa projetar células solares com o melhor desempenho possível, é necessário entender quais as características da luz do sol e os efeitos da sua incidência sobre o dispositivo. Além disso, é natural comparar as fotocélulas construídas ao redor do mundo, verificando o efeito isolado de cada técnica sobre cada uma de suas características e, assim, termos a capacidade de reunir as melhores práticas para produzir células cada vez melhores. Para facilitar essa comparação, o ideal é que se consiga reproduzir as condições de teste ou, ao menos, ter ideia dos efeitos de suas variações. São exemplos dessas condições a temperatura, a pressão, a composição atmosférica, a tensão aplicada sobre a célula, o ângulo de incidência, assim como a homogeneidade, estabilidade temporal e composição espectral do feixe luminoso usado no experimento.

Como já mencionado, os fótons incidentes em uma célula precisam ter uma energia mínima maior que o valor do gap do material para que possam contribuir para a geração de potência elétrica. Por exemplo, células solares de GaAs, cujo gap é $E_{G}=1,424 \mathrm{eV}$ a $300 \mathrm{~K}$, não convertem fótons com energias menores que $E_{G}(\lambda \geq 870,67 \mathrm{~nm})$ em energia elétrica. Por outro lado, elétrons que absorvem fótons com energia muito maior que $1,424 \mathrm{eV}$ tendem a perder $\mathrm{o}$ excesso relativo ao gap por termalização. Note que a termalização, além de constituir uma perda por si só, causa deterioração das propriedades da célula devido ao seu aquecimento. Deste modo, o gap determina de uma só vez o limite inferior de absorção e quanta energia será eventualmente desperdiçada termicamente, caso nenhuma medida extra seja tomada para limitar essas duas fontes de perda.

A figura 32 mostra as características da radiação solar. A curva amarela mostra o espectro de emissão solar no espaço, imediatamente antes de atravessar a atmosfera terrestre, que é muito parecido com o espectro de um corpo negro a $5780 \mathrm{~K}$, temperatura média das camadas externas 
do sol. Seu pico se localiza em $475 \mathrm{~nm}$, na região do visível. A curva colorida mostra o espectro solar ao nível do mar, após a radiação atravessar a atmosfera. Vale ressaltar que, desse espectro que chega ao nível do mar, apenas $5 \%$ do espectro encontra-se no ultravioleta $(300-400 \mathrm{~nm})$, $43 \%$ no visível $(400-700 \mathrm{~nm})$ e $52 \%$ no infravermelho $(700-2500 \mathrm{~nm})$. Isso significa que praticamente metade da energia solar não pode ser aproveita pelas CSs de GaAs, tendo em vista que esse material absorve somente comprimentos de onda abaixo de 870,67 nm (valor que fica no infravermelho próximo. A partir deste fato, fica notória a importância de se desenvolver mecanismos que permitam às CSs absorverem a radiação possuindo energia menor que a do gap de seus materiais [58].

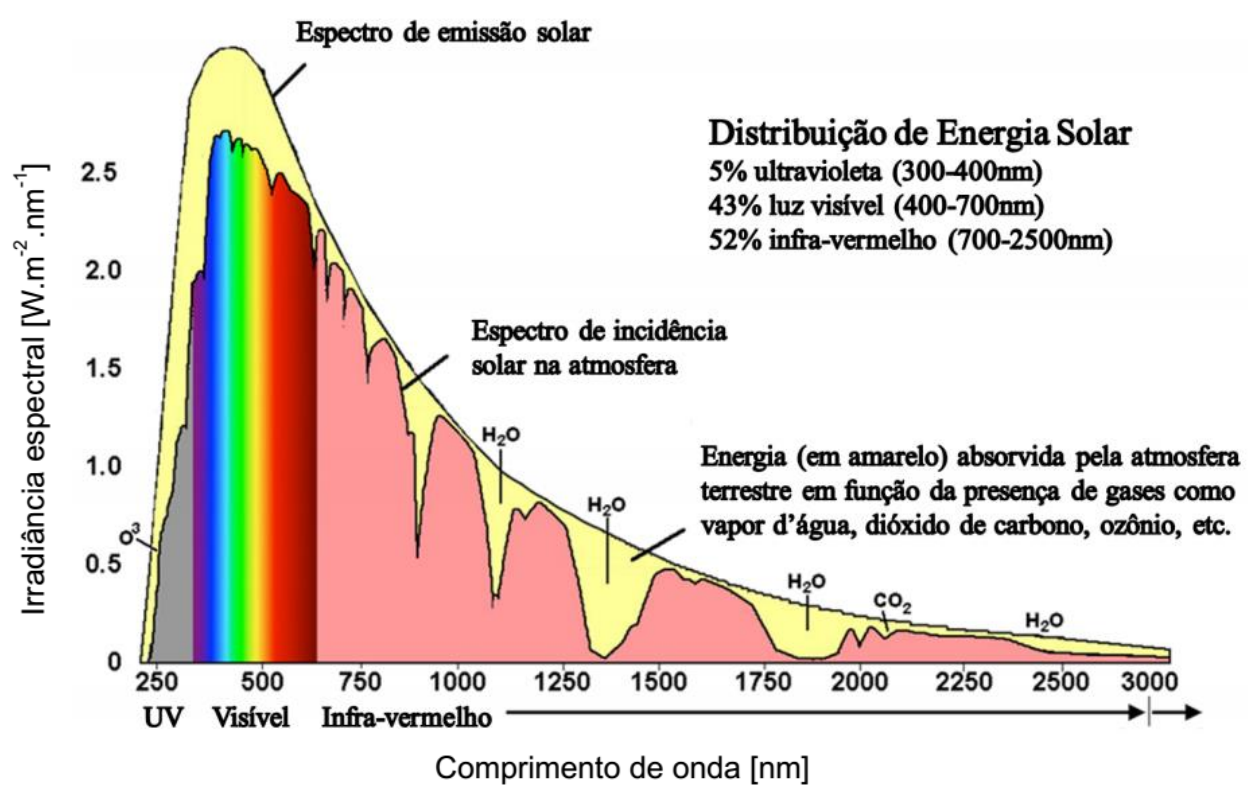

Figura 32: Distribuição de energia do espectro solar. O eixo vertical se relaciona com a quantidade de fótons correspondente a cada comprimento de onda [58].

Naturalmente, a curva colorida da figura 27, é uma média temporal e espacial (sobre áreas representativas do globo terrestre) da radiação solar. Não podemos deixar de considerar que o espectro solar não é uniforme nem no tempo nem no espaço. São exemplos de fatores que influenciam as características do espectro a distância da Terra ao Sol, a absorção pela atmosfera, as variações de temperatura, composição de gases atmosféricos, aerossóis e as localizações no globo terrestre. Claro que este fato traz complicações quando queremos comparar células solares. Para tanto, é necessário se certificar de que as condições de teste são iguais para todos os dispositivos investigados. Por esse motivo, torna-se imprescindível a utilização de um espectro solar padrão.

Existem diversos padrões de distribuição de irradiância, sendo que os mais utilizados atualmente são aqueles definidos pela ASTM International no documento ASTM G173-03 [59]. A nomenclatura desses padrões - por exemplo, AM1.5G - é composta respectivamente pelas letras AM - do inglês "air mass" - seguidas de um número e uma letra. O número está associado com o ângulo de incidência da radiação solar e, portanto, com a espessura da massa de ar que um feixe luminoso viaja ao cruzar a atmosfera terrestre. Ele é definido como:

$$
N=1 / \cos (\theta)
$$


onde $\theta$ é o ângulo entre o feixe incidente e a normal à superfície da Terra no local desejado. Logo, $\mathrm{N}$ é mínimo $(\mathrm{N}=1)$ quando o Sol está no zênite $\left(\theta=0^{\circ}\right)$. Dizemos então que o feixe atravessou 1 atmosfera (ou 1 massa de ar). Caso o feixe incida obliquamente, terá que atravessar mais do que 1 massa de ar, sendo $\theta>0^{\circ}$ e $N>1$. Define-se $\mathrm{N}=0$ para a radiação solar imediatamente antes de ela entrar na atmosfera terrestre.

Já a letra escrita após o valor $\mathrm{N}$ indica se a radiação é originada apenas do feixe que incide diretamente do Sol (D de direto) ou se, além do feixe direto, considera-se também o espalhamento atmosférico ( $\mathrm{G}$ de global), conforme mostra a figura 33.

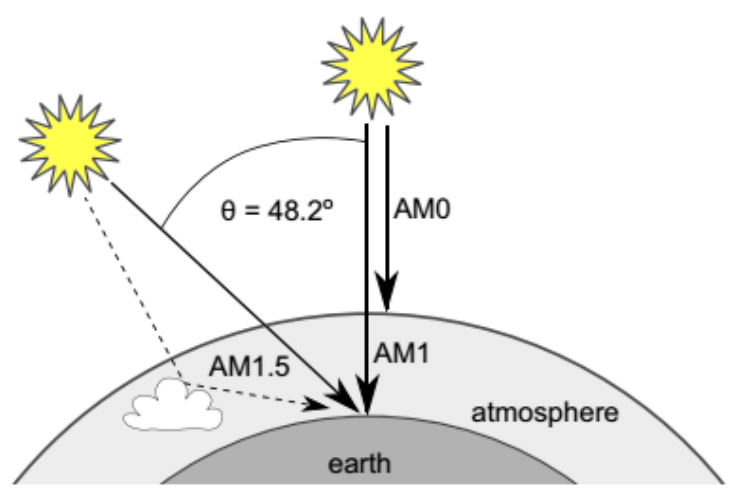

Figura 33: Irradiância solar fora da atmosfera terrestre (AMO), sobre a face da terra com incidência direta no zênite (AM1), com incidência direta de $48.2^{\circ}$ (AM 1.5D) ou considerando também a contribuição do espalhamento atmosférico - linha tracejada - (AM 1.5G), que é o padrão geralmente usado [61].

Portanto: AM0 representa o espectro da radiação solar antes de entrar na atmosfera terrestre, cuja irradiância total (potência por unidade de superfície) é 1366,1 W/m² [7] [60]. Esse padrão de radiação é muito utilizado para avaliar células empregadas em aplicações espaciais, fora da atmosfera terrestre;

AM1 é a referência equivalente à radiação solar que atravessou a atmosfera perpendicularmente à superfície terrestre, percorrendo nela a menor distância possível. É útil na avaliação do desempenho de células utilizadas nas regiões equatoriais e tropicais da superfície da Terra. A irradiância total dos padrões AM1D e AM1G são $868 \mathrm{~W} / \mathrm{m}^{2}$ e $1086 \mathrm{~W} / \mathrm{m}^{2}$, respectivamente [61] [62] [63];

AM1.5 é uma referência para a radiação solar que atravessa uma massa de ar atmosférico maior do que a mínima, quando o ângulo de incidência em relação ao zênite é de $48,2^{\circ}$. É normalmente utilizada para avaliar o desempenho de células em regiões temperadas como as presentes na Europa, China, Japão, Norte da Índia, Sul da África e Austrália. Este padrão foi construído com base na análise de dados de irradiação solar nos Estados Unidos. Ele representa uma média global anual para as latitudes das regiões temperadas e por isso tem sido regularmente utilizado para comparar as células solares do mundo todo desde a década de 70 [64] (Figura 34);

AM1.5D é relevante para sistemas baseados em concentradores solares com espelhos ou lentes. A irradiância total desse espectro é de $900,1 \mathrm{~W} / \mathrm{m}^{2}$ [60] [65]. AM1.5G inclui também o espalhamento da luz e é relevante para sistemas que não fazem uso de concentradores (a maior parte dos sistemas comerciais). A potência integrada desse espectro é de 1000,4 W/ $\mathrm{m}^{2}$ [60] [65]. Este é o padrão utilizado na caracterização das CSs deste trabalho.

A seguir são apresentadas as irradiâncias espectrais de acordo com a norma ASTM G17303 e os gaps dos principais materiais utilizados na tecnologia fotovoltaica [59] [66] (Figura 34). 


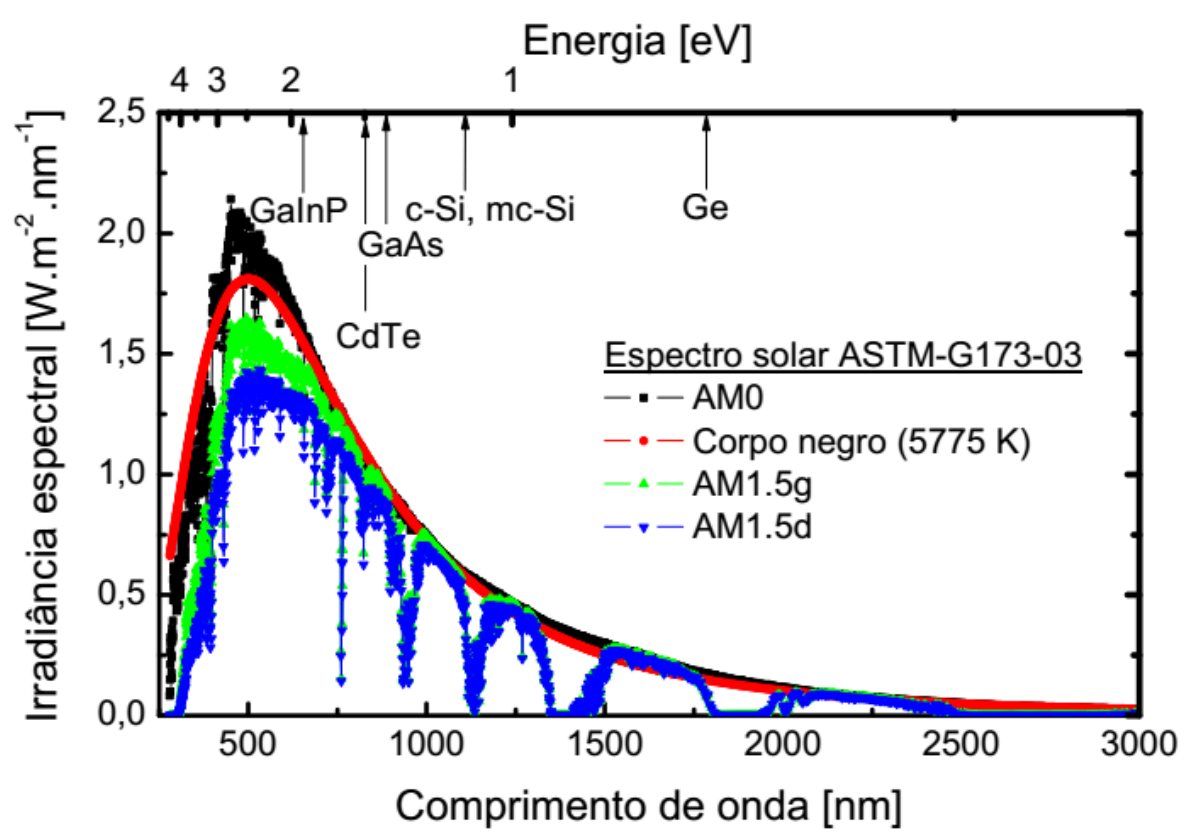

Figura 34: Irradiâncias espectrais de acordo com a norma ASTM G173-03 e os gaps dos principais materiais utilizados na tecnologia fotovoltaica [59] [64] [66].

Apesar de utilizarmos o padrão AM1.5G para efetuarmos as medidas com o nosso simulador solar, por ser o mais utilizado atualmente nas pesquisas sobre a tecnologia fotovoltaica, devemos ter alguns cuidados quando vamos desenvolver projetos de instalação em uma região específica do planeta. Devemos considerar a necessidade de converter os valores das medidas, obtidos com o uso do padrão AM1.5G, para os valores que obteríamos sob as peculiaridades de cada região do planeta e as suas influências no espectro solar (ver o apêndice).

\subsection{Limites de eficiência}

As investigações que levaram ao desenvolvimento das células solares são tipicamente separadas em 3 gerações. A primeira geração corresponde às células de silício de junções mono ou poli cristalinas e domina o mercado mundial. A segunda geração corresponde às células baseadas em filmes finos, tipicamente são depositadas entre um substrato transparente condutor e um eletrodo traseiro. A maioria é baseada em silício amorfo, CIGS (CuInGaSe) e CdTe. A terceira geração corresponde às células projetadas com o objetivo de se alcançar eficiências de conversão que vão além do limite Shockley-Queisser fazendo-se uso de concepções avançadas como as células de múltiplas junções, conversores ópticos up e down, geração de portadores múltiplos por ionização de impacto, células com bandas intermediárias, células com pontos quânticos (QDs), além das CSs de filmes finos de GaAs estudadas nesta dissertação, dentre outras. Portanto, nessa dissertação construímos células de terceira geração, pois as células com pontos quânticos atendem os requisitos que a classificam na terceira geração [67].

O limite Shockley-Queisser, ou Limite de Balanço Detalhado, é o desenvolvimento teórico que estabelece um limite superior para a máxima eficiência de uma célula fotovoltaica baseada numa única junção pn. Esse desenvolvimento foi feito por William Shockley e Hans Queisser em 1961 [16] e assumiu alguns pressupostos básicos, como:

- A potência de apenas um Sol incidindo sobre a fotocélula; 
- Tanto o Sol quanto a fotocélula são considerados corpos negros com $\mathrm{T}_{\mathrm{S}}=6000 \mathrm{~K} \mathrm{e} \mathrm{T}_{\mathrm{C}}=$ $300 \mathrm{~K}$, respectivamente;

- A absorção da célula é uma função degrau (da energia ou do comprimento de onda) com descontinuidade no valor $\mathrm{E}_{\mathrm{G}}$ correspondente ao intervalo de energia proibida. Isto é, a eficiência de geração de pares elétron-buraco é de $100 \%$ quando fótons com energias maiores que o valor de $\mathrm{E}_{\mathrm{G}}$ para o material que constitui a fotocélula a atingem, enquanto fótons com energia menor que $\mathrm{E}_{\mathrm{G}}$ não interagem com a CS;

- A mobilidade dos pares elétron-buraco é infinita, ou seja, é possível a quaisquer elétrons ou buracos gerados alcançar os contatos ou a zona de depleção, independente da distância que precisem percorrer para tanto;

- O único tipo de recombinação que ocorre é a radiativa.

A fração do espectro solar utilizada por uma célula solar ideal de junção PN formada por um material com gap de energia de 1,4 eV, determinada pelo cálculo desenvolvido por Shockley e Queisser, é mostrado na Figura 35. A razão entre a área aproveitada pela célula para a geração de energia e a área correspondente ao espectro AM1.5G corresponde à eficiência de conversão que é de $31 \%$ neste caso [68].

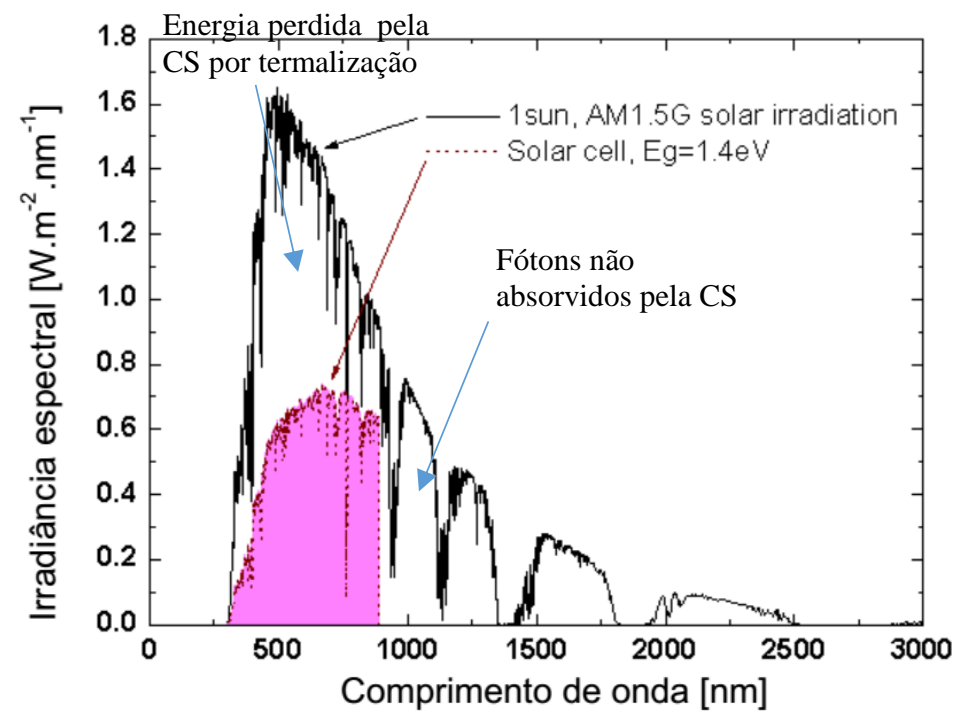

Figura 35: Espectro de irradiação solar padrão AM1.5G, correspondente à intensidade de 1 sol. A fração de energia desse espectro que é absorvida por um material de $E_{G}=1,4$ eVé mostrada em rosa e foi obtida segundo o cálculo desenvolvido por Shockley e Queisser. A eficiência de conversão de energia calculada é de 31,3\% [68].

Considerando o padrão AM 1.5G e utilizando o modelo de Limite de Balanço Detalhado, Sven Rühle [65] apresenta um desenvolvimento onde encontra valores máximos para a corrente de curto circuito $\mathrm{J}_{\mathrm{SC}}$, voltagem de circuito aberto $\mathrm{V}_{\mathrm{OC}}$, eficiência da conversão da potência luminosa em potência elétrica $\eta$, densidade de corrente no ponto de potência máxima $J_{\text {mpp }}$ e tensão no ponto de potência máxima $\mathrm{V}_{\text {mpp }}$ como função do gap dos materiais. Rühle conclui que uma CS ideal a $300 \mathrm{~K}$ com gap de 1,4 eV (muito próximo ao valor real de 1,424 eV do GaAs) deve ter os parâmetros apresentados na Tabela 1 . 
Tabela 1: Eficiência de uma célula solar de junção pn única de GaAs a $25{ }^{\circ} \mathrm{C}$ calculada com o modelo de ShockleyQueisser, supondo uma irradiância espectral AM 1.5G (ASTM G173-03) e uma emissão radiativa tanto do lado frontal como da face oposta à incidência da luz [4]. Eg é o gap do GaAs com o comprimento de onda correspondente $\lambda_{g} ; J_{\max }$ a densidade máxima de fotocorrente ${ }^{14} ; J_{s c}$ a densidade de corrente de curto circuito; $J_{m p p}$ a densidade de corrente no ponto de potência máxima; $V_{o c}$ a voltagem de circuito aberto; $V_{\text {mpp }}$ a voltagem no ponto de potência máxima; FF o fator de preenchimento e $\eta$ a eficiência [65] .

\begin{tabular}{|l|l|l|l|l|l|l|l|l|}
\hline $\mathrm{E}_{\mathrm{g}}(\mathrm{eV})$ & $\lambda_{\mathrm{g}}(\mathrm{nm})$ & $\mathrm{J}_{\max }\left(\mathrm{mA} / \mathrm{cm}^{2}\right)$ & $\mathrm{J}_{\mathrm{sc}}\left(\mathrm{mA} / \mathrm{cm}^{2}\right)$ & $\mathrm{J}_{\mathrm{mpp}}\left(\mathrm{mA} / \mathrm{cm}^{2}\right)$ & $\mathrm{V}_{\mathrm{oc}}(\mathrm{V})$ & $\mathrm{V}_{\mathrm{mpp}}(\mathrm{V})$ & $\mathrm{FF}(\%)$ & $\eta(\%)$ \\
\hline 1,4 & 885,6 & 32,88 & 32,88 & 32,08 & 1,122 & 1,026 & 89,3 & $32,91^{15}$ \\
\hline
\end{tabular}

Podemos ver que, para um gap de 1,4 eV, a eficiência máxima prevista para uma célula de junção simples é 32,91\%. Lembrando que o recorde mundial, segundo a NREL, para as células monocristalinas de GaAs é de 27,8\% (alcançado pela LG), e que para células de filmes finos é de $29,1 \%$ (alcançado pela Alta Devices). Para comparação, Shockley e Queisser mostraram que a máxima eficiência possível $(33,7 \%)$ seria alcançada se o material da junção PN possuísse gap de $1,34 \mathrm{eV}$.

Em uma publicação de novembro de 2012 é mostrado um gráfico (Figura 36) com a máximas eficiência de conversão possíveis, derivado do balanço detalhado, para uma variedade de estratégias avançadas, inclusive para os conceitos que fazem parte da terceira geração de CSs. O cálculo original de Shockley-Queisser para uma célula solar de junção única tradicional também é mostrado, bem como alguns recordes certificados (até novembro de 2012) [67].

Tandem Solar Cells (1-Sun)

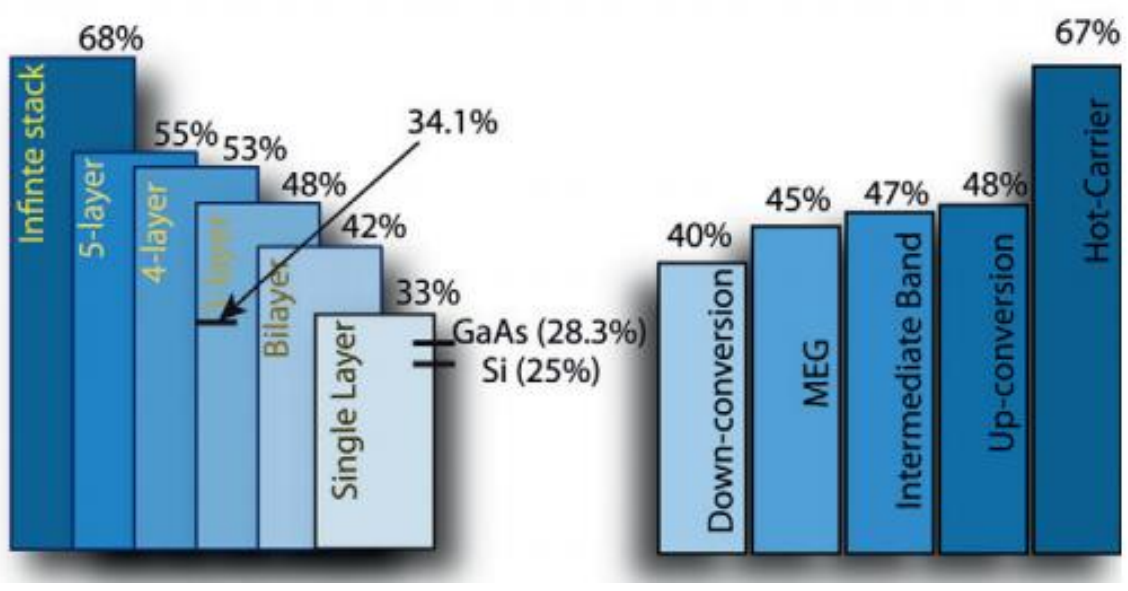

Figura 36: Máximas eficiências de conversão possíveis, derivadas do balanço detalhado para uma variedade de estratégias avançadas que fazem parte da terceira geração. O cálculo original de Schockley-Queisser para uma célula solar de junção única tradicional também é mostrado, bem como alguns recordes certificados (até novembro de 2012). Os pequenos traços pretos horizontais correspondem às eficiências recordes. [67].

${ }^{14}$ É a densidade máxima de corrente, obtida pelo modelo [65], que poderia ser obtida pela geração de elétron-buraco. É diferente da corrente de curto circuito $J_{s c}$ que é a corrente que atravessa o dispositivo quando está em curto. No caso real teremos $J_{s c}<J_{\max }$.

${ }^{15}$ Para se chegar a esse valor de eficiência foi considerado o espetro solar padrão AM 1.5G (ASTM G17303), enquanto que para a eficiência correspondente a área da região rosa da figura 35 foram considerados o sol e a célula solar como corpos negros a $6000 \mathrm{~K}$ e $300 \mathrm{~K}$, respectivamente. 


\subsection{Pontos Quânticos}

Como mencionado anteriormente, ${ }^{16}$ praticamente metade da energia solar não pode ser aproveitada pelas CSs construídas com uma matriz cristalina de GaAs, tendo em vista que esse material é capaz de absorver somente comprimentos de onda abaixo de $870,67 \mathrm{~nm}$. A partir desse fato, fica notória a importância de se desenvolver mecanismos que permitam às CSs absorverem a radiação que possui energia menor que a do gap de sua matriz [69], formada por GaAs no nosso caso. Um modo de se fazer isso é inserir pontos quânticos $\left(\mathrm{QDs}^{17}\right)$ na matriz das CSs. Essas estruturas foram propostas em 1982, por Arakawa e Sakaki [70], como sendo capazes de incrementar a performance de dispositivos optoeletrônicos. Mas é só no início da década de 90 , com a descoberta do processo de auto-formação dos QDs durante o crescimento epitaxial de camadas sob tensão [71], que foi possível produzir estruturas com boa qualidade cristalina e pequenas o bastante para garantir os efeitos de confinamento desejados (figura 37).
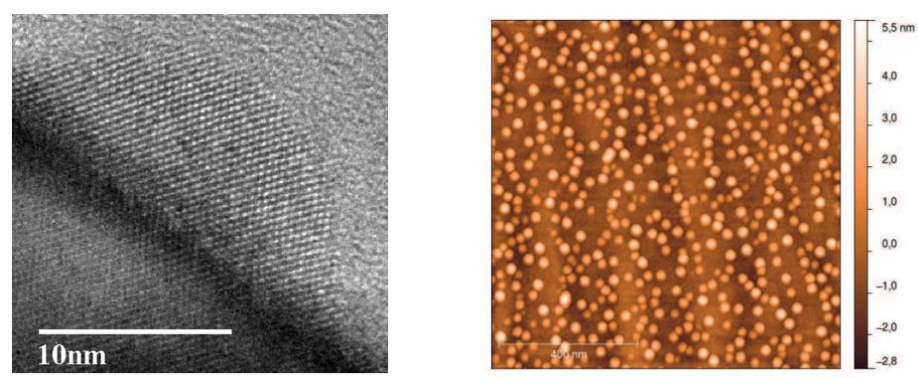

Figura 37: (esquerda) Imagem de TEM ${ }^{18}$, em seção transversa, de um ponto quântico de InAs depositado em nosso grupo sobre uma superficie de GaAs nas mesmas condições que aquelas usadas neste trabalho. (direita) Imagem de AFM mostrando os QDs de InAs da mesma amostra.

Um QD é uma estrutura com dimensão da ordem do comprimento de onda de Broglie dos elétrons, ou seja, de até algumas dezenas de nanômetros nas três direções do espaço [72], à qual um elétron pode se ligar com uma energia bem definida tal como se ligaria a um único átomo. Por isso, algumas vezes são chamados de átomos artificiais. Assim, o QD se comporta como um poço de potencial tridimensional.

A energia dos elétrons confinados depende do tamanho do $\mathrm{QD}$, analogamente à maneira em que os níveis em um poço quântico dependem da largura do poço. A grande vantagem do domínio da técnica de formação dos QDs é a possibilidade de se sintonizar níveis entre as bandas de valência e de condução da matriz que possibilitam a absorção de fótons com energias menores que a do gap desse material [73]. Isso proporciona a possibilidade fascinante de podermos aproveitar parte dessa enorme fração do espectro solar que normalmente é desperdiçada pelas CSs sem QDs.

\footnotetext{
${ }^{16}$ No tópico "2.7. Radiação solar e espectro solar padrão”.

${ }^{17} \mathrm{QD}$, do inglês quantum dot.

18 TEM, do inglês "transmission electron microscopy" é uma técnica de microscopia em que um feixe de elétrons é transmitido através de uma região da amostra extremamente fina para formar uma imagem do material em escala nanomêtrica.
} 


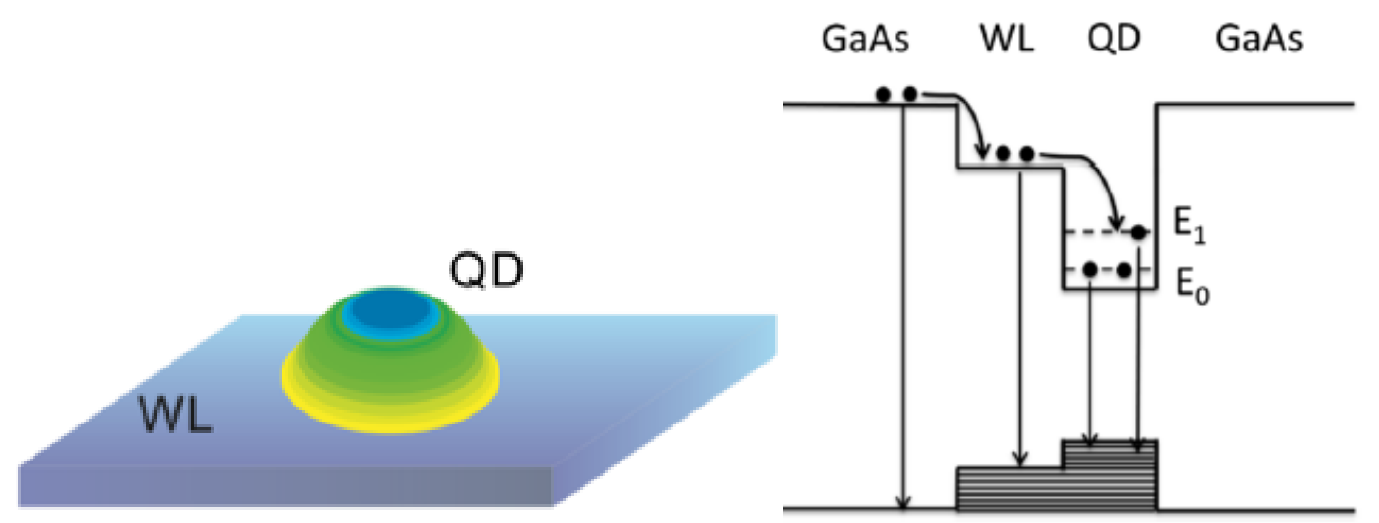

Figura 38: Distribuição de carga nos QDs e diagramas que descrevem as vias de relaxação de elétrons em CSQDSKs de InAs/GaAs, onde $E_{0}$ e $E_{1}$ são o estado fundamental e o primeiro estado excitado, respectivamente [73].

Os novos níveis discretos de energia criados pelos QDs podem ser sintonizados mudandose o seu tamanho, forma e composição. Quando possuem dimensões maiores, absorvem fótons de menor energia, levando à emissão de luz em comprimentos de onda maiores, como pode ser verificado num experimento de fotoluminescência (como será mostrado mais adiante). A grande vantagem dos QDs sobre outros sistemas de baixa dimensionalidade - tais como poços quânticos e nanofios - é que, com eles, os portadores possuem um espectro de energia totalmente discreto, pois o tamanho deles é extremamente reduzido e os portadores são confinados nas três direções do espaço. Isso propicia um confinamento dos portadores de melhor qualidade e leva a uma melhor estabilidade dos dispositivos em função da temperatura [74] [75]. Nesse trabalho, os pontos quânticos foram formados a partir de um fino filme de InAs que sofreu uma transformação espontânea de morfologia, dando lugar a pequenas ilhas de InAs, como será explicado mais adiante. Como o InAs possui um gap menor que o GaAs, os níveis discretos de energia nos pontos quânticos estarão localizados dentro do gap do GaAs e possibilitarão assim a absorção da radiação que normalmente atravessa o dispositivo sem ser absorvida. 


\section{Materiais e métodos}

Nesse tópico os materiais e métodos utilizados na produção e caracterização das CSs estudadas neste trabalho são discutidos. Em síntese, o procedimento de produção das CSs deu-se através das seguintes etapas:

(i) planejamento das amostras;

(ii) crescimento das camadas cristalinas que compõem as células via epitaxia por feixes moleculares;

(iii) fotolitografia para definir fisicamente as CSs;

(iv) deposição dos contatos elétricos via evaporação por e-beam;

(v) tratamento térmico para melhorar os contatos elétricos.

As técnicas utilizadas para caracterizar as CSs e seus contatos foram:

(vi) método de transmissão por linha (TLM) para avaliar a resistência dos contatos;

(vii) microscopia por força atômica $\left(\mathrm{AFM}^{19}\right)$ para caracterizar a geometria e densidade dos pontos quânticos de Stranski-Krastanov (SK);

(viii) fotoluminescência para confirmar a presença e caracterizar os níveis eletrônicos dos pontos quânticos;

(ix) medidas de curvas $\mathrm{I} \times \mathrm{V}$ com o simulador solar para determinação das figuras de mérito das CSs.

\subsection{Planejamento das amostras}

A princípio tínhamos em mente construir uma CS de estrutura PIN contendo apenas GaAs para ser utilizada como referência e uma variação, com estrutura similar, mas com QDs inseridos na camada I da estrutura PIN para que pudéssemos verificar a influência dos QDs no desempenho das CSs. No entanto, no decorrer do trabalho, optamos por produzir também mais 2 tipos de CSs, que são outras variações da amostra de referência para verificar se a introdução de algumas camadas de AlGaAs pudesse tornar as CSs mais eficientes. Assim, destacando a estrutura de referência e as estruturas das células que são variações, construímos as 4 amostras seguintes:

I) 3910: Amostra de referência, à qual nos referimos como CS-GaAs para ressaltar que é uma estrutura básica formada apenas por GaAs;

II) 3908: Amostra com adição de janela $\left(\mathrm{FSF}^{20}\right)$ de $\mathrm{AlGaAs}$, à qual nos referimos como CS-FSF para ressaltar a presença dessa estrutura;

III) 3906: Amostra com adição de janela e com $\mathrm{BSF}^{21}$, ambos de AlGaAs, à qual nos referimos como CS-F\&BSF, para ressaltar a presença dessas estruturas;

IV) 3909: Amostra com adição de janela e de pontos quânticos, à qual nos referimos como CS-QDSK para ressaltar a presença dos pontos quânticos (QDs) formados no mmodo de crescimento de Stranski-Krastanov (SK).

\footnotetext{
${ }^{19}$ AFM, do inglês "atomic force microscopy".

${ }^{20} \mathrm{FSF}$, do inglês "front surface field";

${ }^{21} \mathrm{BSF}$, do inglês back surface field.
} 
A seguir descrevemos os detalhes das estruturas epitaxiais das amostras e explicamos como faremos para verificar o efeito das estruturas introduzidas nas amostras que são variações da amostra de referência.

\subsubsection{Junção PIN básica}

Lembrando que a junção PIN é composta por 3 camadas (

Figura 39), temos, para a formação da camada tipo $\mathrm{N}$ da base, uma camada de GaAs dopada com átomos de Si a $1 \times 10^{18} \mathrm{~cm}^{-3}$, com espessura de $3000 \AA ̊$; em cima dessa, para a formação da camada I, depositamos uma camada de GaAs intrínseco, com espessura de $1 \mu \mathrm{m}$; e, em cima dessa, depositamos, para a formação da camada tipo $\mathrm{P}$ do emissor, uma camada de GaAs dopado com átomos de $\mathrm{C} \mathrm{a} 1 \times 10^{18} \mathrm{~cm}^{-3}$, com espessura de $1000 \AA$ A . Usamos essa estrutura de referência com essas espessuras para poder comparar nossos resultados com os obtidos recentemente em alguns trabalhos do grupo da Profa. Patrícia Lustoza de Souza, da PUC-Rio, com quem colaboramos. As espessuras das camadas ainda precisam ser otimizadas para melhorar a eficiência, mas como o crescimento de amostras é bastante demorado e caro, optamos por não realizar esse estudo e a otimização nesse trabalho, mas é algo que vem sendo planejado para ser feito em um próximo trabalho.

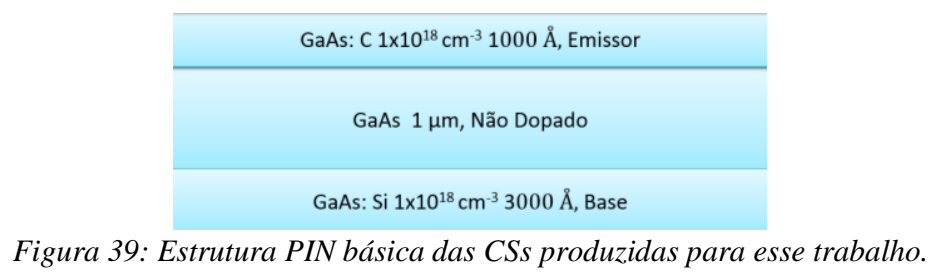

\subsubsection{CS-GaAs}

A célula de referência CS-GaAs que construímos é formada por uma estrutura PIN que está localizada entre duas camadas altamente dopadas, uma acima do emissor (Cap Dopado de $300 \AA$ de espessura, dopada com C a $1 \times 10^{19} \mathrm{~cm}^{-3}$ ) e outra abaixo da base (BSF de $5000 \AA$ de espessura, dopada com Si a $5 \times 10^{18} \mathrm{~cm}^{-3}$ ).

O Cap Dopado serve para diminuir a barreira Shottky e a resistividade do contato superior tipo P ("finger"). Em princípio, essa camada deve estar apenas sob o metal que forma o contato, pois é capaz de absorver parte da radiação luminosa incidente já que contém uma alta densidade de elétrons livres ${ }^{22}$. No entanto, essa dopagem precisa ser otimizada, porque uma dopagem excessiva pode fazer com que a resistência aumente [76]. Essa otimização será objeto de estudos futuros.

No caso do BSF, ele gera um campo que repele os portadores minoritários na interface entre a base da CS e o substrato, evitando assim a recombinação no contato inferior. Pode também reduzir a difusão dos dopantes e evitar, assim, uma recombinação alta que afetaria tanto a

\footnotetext{
${ }^{22}$ Como existe uma dopagem alta no semicondutor ele adquire um caráter metálico.
} 
fotocorrente como o parâmetro $\mathrm{V}_{\mathrm{OC}}$ [21] [55]. Por isso, é esperado que a presença da BSF melhore a eficiência do dispositivo.

Para construir uma junção PIN de qualidade, devemos atentar para mais um detalhe importante na sua construção. Idealmente, a base deveria ser depositada sobre um material cristalino perfeito, com parâmetro de rede [56] bem definido. Assim, os átomos depositados (Figura 40) se ajustariam a esse parâmetro de rede, onde houvessem sítios disponíveis, de preferência na beira dos terraços atômicos, de modo a minimizar a energia do sistema.

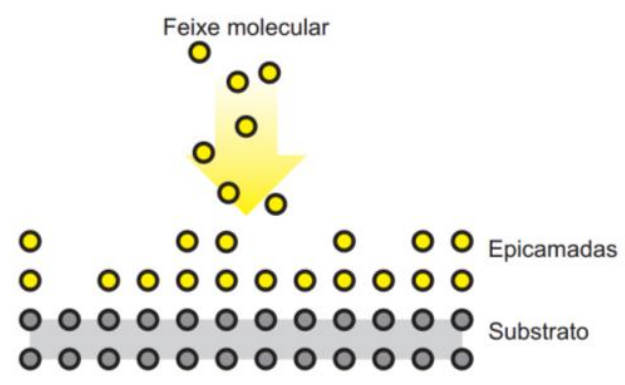

Figura 40: Crescimento epitaxial. Os átomos ou moléculas do feixe incidente se ajustam ao parâmetro de rede do substrato [56].

No entanto, quando há defeitos ou impurezas, surgem interrupções na periodicidade da estrutura cristalina, fazendo com que o material depositado não possa formar as epicamadas da forma planejada. Por isso, antes de iniciar a construção de cada amostra, para diminuir o número de defeitos, depositamos uma camada de GaAs que chamamos de camada "buffer" que possui menor número de defeitos do que o substrato de GaAs de fábrica.

\begin{tabular}{c}
\hline GaAs: C $1 \times 10^{19} \mathrm{~cm}^{-3} 300 \AA$, Cap Dopado \\
\hline GaAs: $\mathrm{C} 1 \times 10^{18} \mathrm{~cm}^{-3} 1000 \AA \AA$, Emissor \\
\hline GaAs $1 \mu \mathrm{m}$, Não Dopado \\
\hline GaAs: Si $1 \times 10^{18} \mathrm{~cm}^{-3} 3000 \AA$, Base \\
\hline GaAs: Si $5 \times 10^{18} \mathrm{~cm}^{-3} 5000 \AA$, BSF \\
\hline GaAs: Si $1 \times 10^{18} \mathrm{~cm}^{-3} \sim 1000 \AA$, Buffer \\
\hline GaAs: Si $(001){ }^{1 / 4} 3^{\prime \prime}$, Substrato Dopado \\
Figura $41:$ Estrutura da célula de referência, CS-GaAs.
\end{tabular}

\subsubsection{CS-FSF}

O papel da janela é passivar os estados da superfície do emissor que podem agir como armadilhas para os portadores de carga minoritários e, dessa forma, ajuda a diminuir a taxa de recombinação nessa superfície [21] [55]. Isso deve fazer com que a eficiência do dispositivo aumente. A janela deve ser construída de modo a permititir a passagem de uma fração significativa dos fótons com energia suficiente para proporcinar a absorção pela pela junção PIN. Por isso devemos ter cuidado para que a janela seja contruída com um material de gap mais alto 
que o cristal matriz da junção PIN, que é o GaAs no nosso caso. $\mathrm{O} \mathrm{Al}_{\mathrm{x}} \mathrm{Ga}_{1-\mathrm{x}} \mathrm{As}$ cumpre bem esse papel, pois sempre terá gap maior que o $1,42 \mathrm{eV}$ do GaAs [77].

Para que possamos observar o efeito da janela, construímos a CS-FSF de tal maneira que a única diferença com a CS-GaAs seja a presença de uma fina camada (janela) de $\mathrm{Al}_{\mathrm{x}} \mathrm{Ga}_{1-\mathrm{x}} \mathrm{As}$, com 28\% de Al, entre o Cap Dopado e o emissor. Portanto, podemos comparar a CS-FSF com a CS-GaAs para verificar o efeito da introdução da janela.

\begin{tabular}{|c|}
\hline GaAs: C $1 \times 10^{19} \mathrm{~cm}^{-3} 300 \AA$, Cap Dopado \\
\hline $\mathrm{Al}_{\mathrm{x}} \mathrm{Ga}_{1-x} \mathrm{As}: \mathrm{C} 1 \times 10^{19} \mathrm{~cm}^{-3} 300 \AA, \mathrm{x}=28 \%$, Janela (FSF) \\
\hline GaAs: C $1 \times 10^{18} \mathrm{~cm}^{-3} 1000 \AA$, Emissor \\
\hline GaAs $1 \mu \mathrm{m}$, Não Dopado \\
\hline GaAs: Si $1 \times 10^{18} \mathrm{~cm}^{-3} 3000 \AA$, Base \\
\hline GaAs: Si $5 \times 10^{18} \mathrm{~cm}^{-3} 5000 \AA$, BSF \\
\hline GaAs: Si $1 \times 10^{18} \mathrm{~cm}^{-3} \sim 1500 \AA$, Normal \\
\hline GaAs: Si (001) 1/4 3", Substrato Dopado \\
\hline
\end{tabular}

Figura 42: Estrutura da célula com janela, CS-FSF.

\begin{tabular}{c}
\hline GaAs: C $1 \times 10^{19} \mathrm{~cm}^{-3} 300 \AA$, Cap Dopado \\
\hline GaAs: $\mathrm{C} 1 \times 10^{18} \mathrm{~cm}^{-3} 1000 \AA$, Emissor \\
\hline GaAs $1 \mu \mathrm{m}$, Não Dopado \\
\hline GaAs: Si $1 \times 10^{18} \mathrm{~cm}^{-3} 3000 \AA$, Base \\
\hline GaAs: $S$ i $5 \times 10^{18} \mathrm{~cm}^{-3} 5000 \AA$, BSF \\
\hline GaAs: Si $1 \times 10^{18} \mathrm{~cm}^{-3} \sim 1000 \AA \AA$, Buffer \\
\hline GaAs: Si $(001) 1 \% 3^{\prime \prime}$, Substrato Dopado
\end{tabular}

Figura 43: Estrutura da célula de referência, CS-GaAs.

\subsubsection{CS-F\&BSF}

A estrutura da CS-F\&BSF é quase idêntica à estrutura da CS-FSF. A diferença é que na amostra CS-F\&BSF é inserida uma camada de $1000 \AA$ de espessura, composta de $\mathrm{Al}_{\mathrm{x}} \mathrm{Ga}_{1-\mathrm{x}} \mathrm{As}$ com $27 \%$ de $\mathrm{Al}$, entre a base e o substrato dopado para gerar o BSF. É possível, com isso, comparar a CS-F\&BSF com a CS-FSF para verificar o efeito da substituição da BSF de GaAs da CS-FSF pela BSF formada por uma camada de $\mathrm{Al}_{\mathrm{x}} \mathrm{Ga}_{1-\mathrm{x}} \mathrm{As}$.

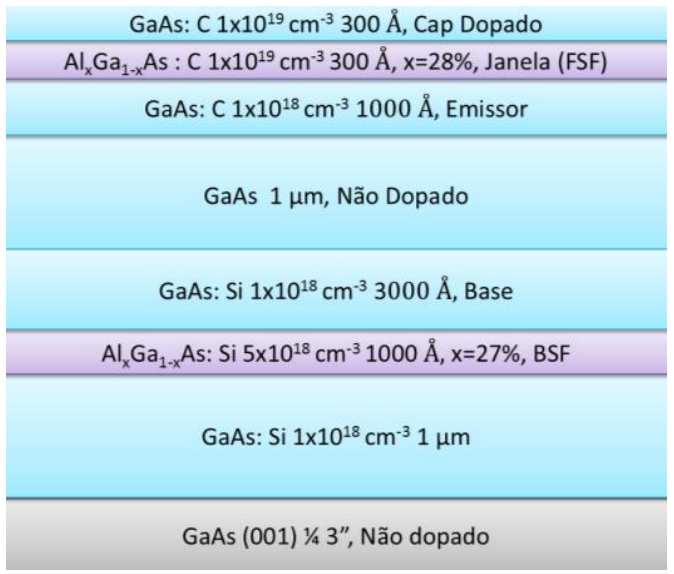

Figura 44: Estrutura da célula com janela e BSF de $A l G a A s, C S-F \& B S F$.

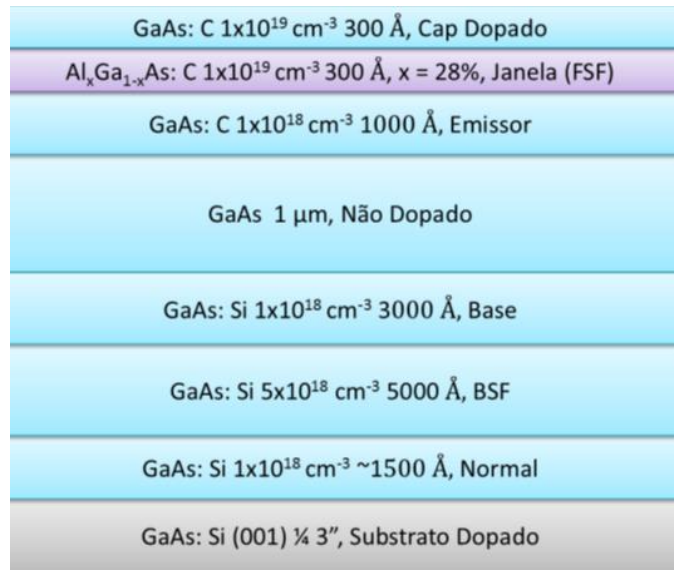

Figura 45: Estrutura da célula com janela, CS-FSF. 


\subsubsection{CS-QDSK}

A estrutura da CS-QDSK é quase idêntica à estrutura da CS-FSF, a diferença sendo que introduzimos 10 camadas de QDs de InAs no meio da camada I da estrutura PIN, sendo que cada uma foi separada das outras por $400 \AA$ de GaAs não dopado. Assim, podemos verificar se a eficiência da CS-QDSK aumenta, quando comparada com CS-FSF, devido à absorção suplementar dos pontos quânticos numa faixa do infravermelho abaixo do gap do GaAs, como esperado. Cada camada de QDs é formada pelo crescimento de 2,2 MCs de InAs, no regime de Stranski-Krastanov, e a dopagem com Si foi feita simultaneamente para ter 4 átomos de dopantes para cada QD.

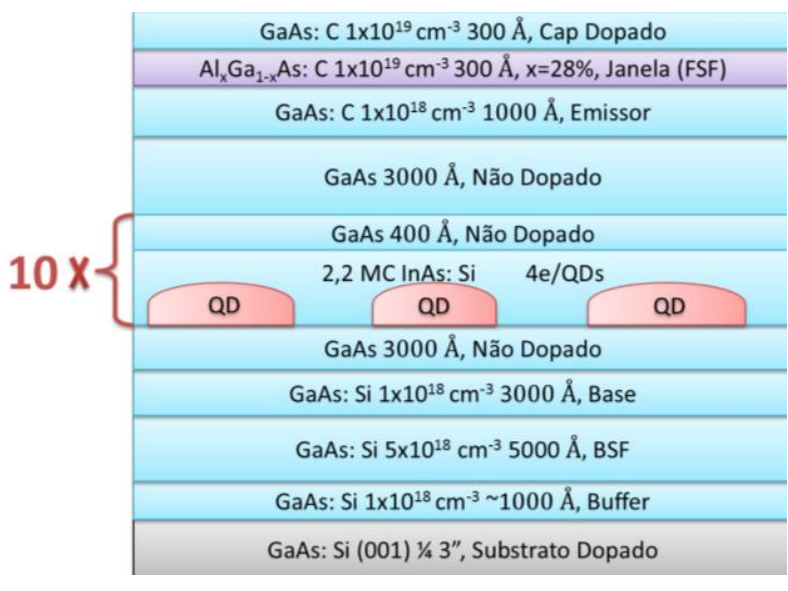

Figura 46: Estrutura da célula com pontos quânticos CS-QDSK.

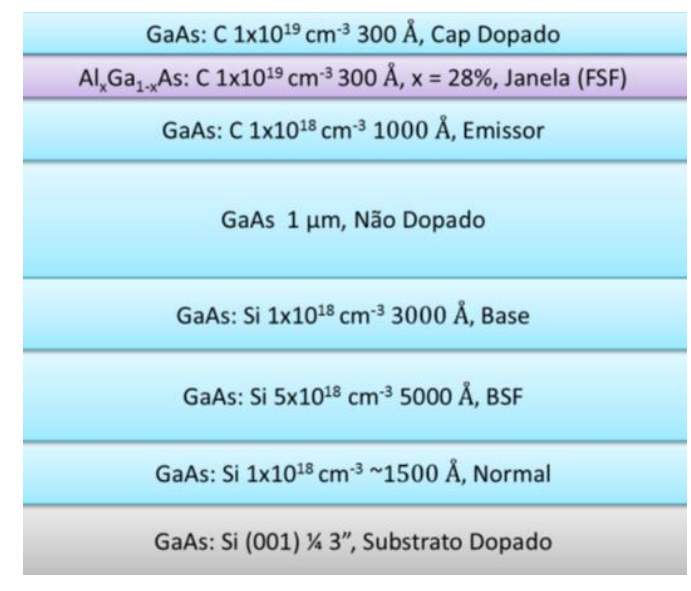

Figura 47: Estrutura da célula com janela, CS-FSF.

\subsection{A técnica MBE}

A técnica $\mathrm{MBE}^{23}$ consiste em realizar deposições de camadas atômicas cristalinas em ambiente de ultra alto vácuo, através de feixes de materiais com fluxos ajustáveis, num ambiente em que o tipo de átomos presentes e a temperatura são controlados (Figura 48). Com essa técnica, podemos realizar deposições de camadas com espessura de poucos átomos, formando ligas que podem ser dopadas de acordo com uma estrutura planejada, como as descritas no tópico 3.1. Como é possível a construção de estruturas com dimensões na escala atômica, podemos explorar os efeitos quânticos dessa escala.

\footnotetext{
${ }^{23} \mathrm{MBE}$, do inglês "Molecular Beam Epitaxy" que em português pode ser traduzido como epitaxia por feixes moleculares.
} 


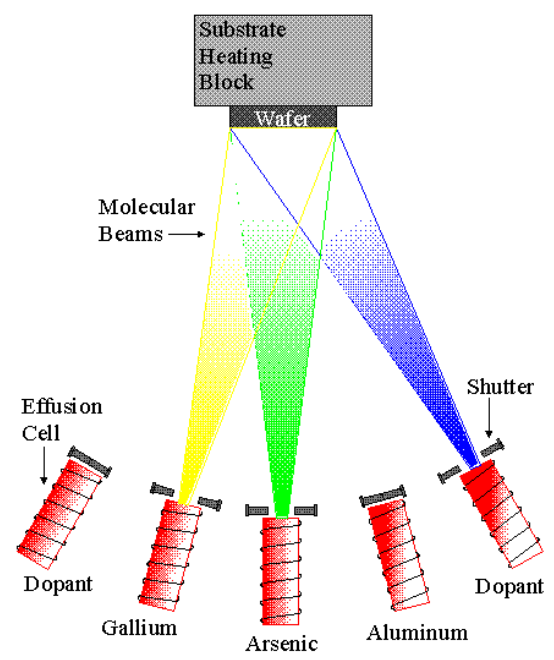

Figura 48: Esquema de um sistema MBE

Para produzir as amostras desse trabalho, utilizamos um sistema MBE Mod Gen 2 da empresa Varian, instalado no nosso laboratório, constituído por 3 câmaras: a câmara de entrada/saída (CES), a câmara intermediária (chamada "buffer",(CB)) e a câmara de crescimento (CC).

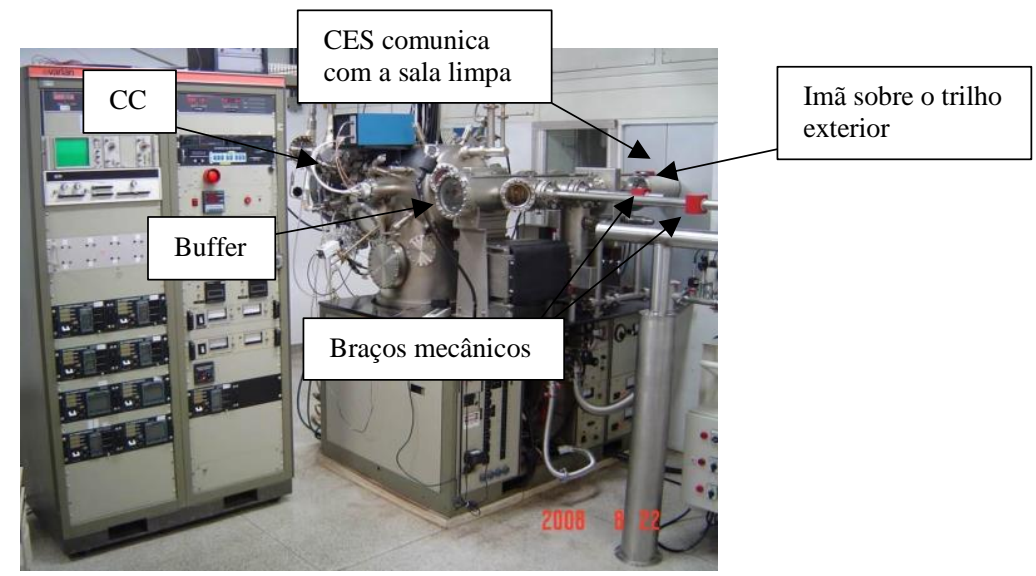

Figura 49: Sistema MBE do LNMS-USP, modelo Mod Gen 2 da empresa Varian.

A porta de entrada da CES é localizada numa sala limpa. Por isso, o manuseio desse sistema requer o entendimento sobre os procedimentos realizados nesse ambiente controlado, onde o número de partículas no ar, a umidade, a temperatura e a pressão são controlados por um sistema de retroalimentação. Isso evita que tanto o sistema MBE como as amostras sejam contaminados com uma quantidade excessiva de partículas provenientes de uma atmosfera não controlada. No mais, oscilações excessivas nas características do ambiente poderiam fazer com que os resultados dos experimentos variassem muito e de forma imprevisível. Ainda, levando-se em conta o problema da contaminação, a manipulação das amostras dentro de sistema MBE é feita de modo a diminuir o máximo possível o contato com o ambiente externo. As amostras são transferidas da CES para a CB por um carrinho metálico (Figura 50), que é deslocado por um imã externo e que anda sobre um trilho, por dentro do sistema. 


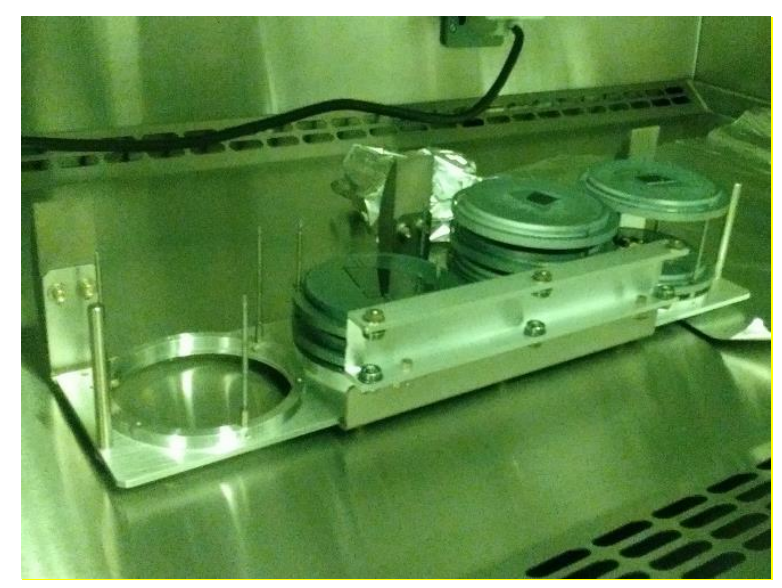

Figura 50: Carrinho para o deslocamento das amostras entre a CES e a CB.

Mas, mesmo quando tomadas todas as precauções para evitar a contaminação do sistema e das amostras, ainda pode haver alguma impureza, que mesmo que já bastante mitigada, pode causar defeitos indesejados durante o crescimento, fazendo com que as epicamadas não possam se formar devido a falhas na periodicidade do substrato cristalino de GaAs. Para tentar minimizar esse problema, após se fazer o vácuo na CES, com um conjunto constituído por uma bomba mecânica sem óleo e uma bomba turbomolecular, liga-se uma bomba iônica conectada a CES e realiza-se a desgaseificação - das amostras, do carrinho e da CES do sistema MBE que foi aberta no ambiente da sala limpa - a uma temperatura de aproximadamente $200{ }^{\circ} \mathrm{C}$ por uma hora, a fim de remover as impurezas adsorvidas durante os trabalhos efetuados na sala limpa. No final desse processo, o sensor de vácuo da CES deve medir uma pressão da ordem de $10^{-8}$ torr. Quando isso ocorrer, podemos transferir as amostras para a câmara intermediária $(\mathrm{CB})$, onde sofrerão um novo processo de desgaseificação, desta vez individual para cada amostra, com temperatura de aproximadamente $350^{\circ} \mathrm{C}$ por 30 minutos. $\mathrm{Na} \mathrm{CB}$, a pressão é geralmente da ordem de $1-5 \times 10^{-10}$ Torr. Depois disso, com auxílio de braços mecânicos, podemos introduzir as amostras na CC para o crescimento das estruturas.

A CC possui vários sensores de pressão e de fluxo, um sistema RHEED ${ }^{24}$ para análise da superfície das amostras in situ, assim como para a determinação das taxas de deposição e da composição dos materiais, células de efusão que fornecem os feixes colimados de materiais utilizados para as deposições, bombas iônica e de sublimação de Ti, um espectrômetro quadrupolar de massa para analisar a composição do ambiente residual e um painel criogênico refrigerado por nitrogênio líquido para melhorar ainda mais as condições de vácuo, através do resfriamento do ambiente. Esse painel também serve para isolar termicamente as células de efusão, o que possibilita um controle mais preciso da temperatura de cada uma delas.

O sistema MBE possui 7 células de efusão: duas de Gálio, uma de Alumínio, uma de Índio e uma de Arsénio que possibilitam a deposição de ligas binárias como GaAs, AlAs e InAs, assim como as ternárias AlGaAs e InGaAs. Células de Si e C são usadas para se obter camadas dopadas do tipo $\mathrm{N}$ (com $\mathrm{Si}$ ) ou do tipo $\mathrm{P}$ (com C). Cada célula é aquecida individualmente por uma fonte de potência, controlada por uma eletrônica que serve para ajustar a intensidade, fazendo passar uma corrente elétrica dentro de uma resistência localizada em volta do cadinho que contém o material a ser evaporado. O aquecimento das células provoca a formação de um feixe de

24 RHEED, do inglês "Reflection High Energy Electron Diffraction", que pode ser traduzido para o português como difração e reflexão de elétrons de alta energia. No caso, parte do feixe incidente de elétrons sofre reflexão especular pela superfície, e parte sofre difração pelas camadas atômicas superiores da amostra, gerando um padrão complexo numa tela fosforescente. 
materiais que se propaga em linha reta, no vácuo da câmara, até atingir o substrato que é aquecido de maneira a favorecer a formação das camadas monocristalinas. A interrupção de cada feixe é possível graças à abertura e fechamento de um obturador pneumático ("shutter") na frente de cada célula. A composição e espessura precisa de cada camada são determinadas pelo tempo de abertura dos obturadores e pela temperatura das células que é função da potência a que cada resistência das células de efusão é submetida. Os obturadores e as fontes de potência podem ser controlados por um computador ou acionados manualmente por um painel. Antes de as amostras serem crescidas, são verificadas as taxas de deposição de cada material através do sistema RHEED, e o nível de dopagem é acertado com a ajuda de curvas de calibração resultando da análise das medidas de efeito Hall realizadas em amostras específicas uma vez por ano.

Com já mencionado acima, a técnica MBE consiste normalmente em depositar um material sobre um substrato de estrutura cristalina e parâmetro de rede parecido. Isso é feito em condições de ultra alto vácuo, sobre um substrato aquecido e monocristalino, com materiais de altíssima pureza para que o filme seja de boa qualidade, com uma densidade mínima de defeitos e impurezas não intencionais. Isso vale para o crescimento das camadas de GaAs e AlGaAs. Todavia, para obter pontos quânticos de InAs de boa qualidade, o método é levemente modificado. Para evitar de ter que formar os pontos quânticos por processos litográficos que costumam produzir um grande número de defeitos, desenvolveu-se uma técnica epitaxial baseada na deposição de filmes sob alta tensão mecânica no regime de crescimento de Stranski-Krastanov ilustrado na Figura 51.

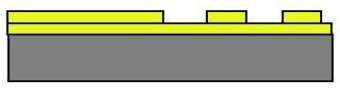

$\mathrm{Esp}<1,7 \mathrm{MC}$

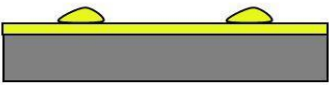

$\mathrm{Esp} \approx 1,7 \mathrm{MC}$

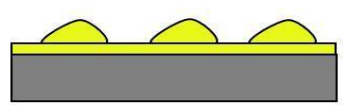

$1,7 \mathrm{MC}<\mathrm{Esp}<3, \mathrm{OMC}$

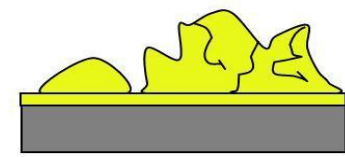

Esp>3,OMC

Figura 51: Método de crescimento de QDs de Stranski-Krastanov [78].

Quando um material semicondutor é depositado em cima de outro semicondutor cristalino que possui um parâmetro de rede diferente, o filme pode crescer sob tensão mecânica, camada atômica por camada atômica, de maneira epitaxial, com a mesma estrutura cristalina e o mesmo parâmetro de rede lateral que o do substrato, até alcançar uma espessura crítica que depende principalmente da diferença de parâmetro de rede entre os dois sistemas em contato [79]. Acima dessa espessura, a energia elástica armazenada na camada epitaxial é tal que linhas de deslocações são criadas para relaxar a tensão, o que permite que o material adote localmente seu parâmetro de rede natural. Neste caso, o filme apresenta numerosos defeitos estruturais e a rugosidade da superfície aumenta rapidamente com o número de camadas depositadas. Se o material depositado possuir um parâmetro de rede significativamente maior que o do substrato, existe um mecanismo preliminar para relaxar parcialmente a tensão elástica antes da introdução dos defeitos estruturais no filme. Nesse caso, o excesso de energia elástica armazenada no sistema favorece o rearranjo da camada epitaxial, formando uma alta densidade de pequenas ilhas de material cristalino sob tensão, os pontos quânticos de Stranski-Krastanov (QDSK), que providenciam uma diminuição da energia total pelo relaxamento da tensão na borda destas pequenas estruturas tridimensionais. Pontos quânticos de InAs sobre GaAs de excelente qualidade podem geralmente ser obtidos com espessuras da camada de InAs variando de 1.7 a $2.4 \mathrm{MC}$, levando a densidades de QDs na faixa de $10^{10} \mathrm{~cm}^{2}$ possuindo uma altura e base de até 7 e $25 \mathrm{~nm}$, respectivamente. 


\subsection{Fotolitografia}

O processo de fotolitografia serve tanto para definir fisicamente, por corrosão química, a área das regiões ativas das células solares quanto para preparar a amostra para a deposição dos metais em regiões específicas onde serão formados os contatos elétricos nas camadas $\mathrm{P}$ e N. O princípio da fotolitografia consiste em transferir para a superfície da amostra um padrão predefinido de fotorresiste (resina fotossensível) que protegerá regiões específicas nas etapas posteriores de corrosão química, remoção de óxidos e deposição metálica. Para isso, são utilizadas máscaras contendo os padrões a serem transferidos, uma resina fotossensível ${ }^{25}$ à radiação ultravioleta (UV), uma fonte de radiação UV e um revelador ${ }^{26}$. A seguir apresento os equipamentos, os materiais e as etapas que utilizei (e otimizei) nos processos fotolitográficos de forma geral para depois indicar os casos particulares, no tópico 3.3.1. Fotolitografia Negativa" e no tópico "3.3.2. Fotolitografia Positiva".

Além de definir a geometria das células, o padrão de fotorresiste que é formado sobre a amostra nas etapas da fotolitografia deve também delimitar as regiões específicas onde serão depositados os metais para a formação dos contatos, sendo que onde não deve ocorrer deposição a amostra deve ser protegida pela camada de fotorresiste durante a etapa de metalização. A resina que utilizamos, o fotorresiste AZ5214, atende bem a essas necessidades.

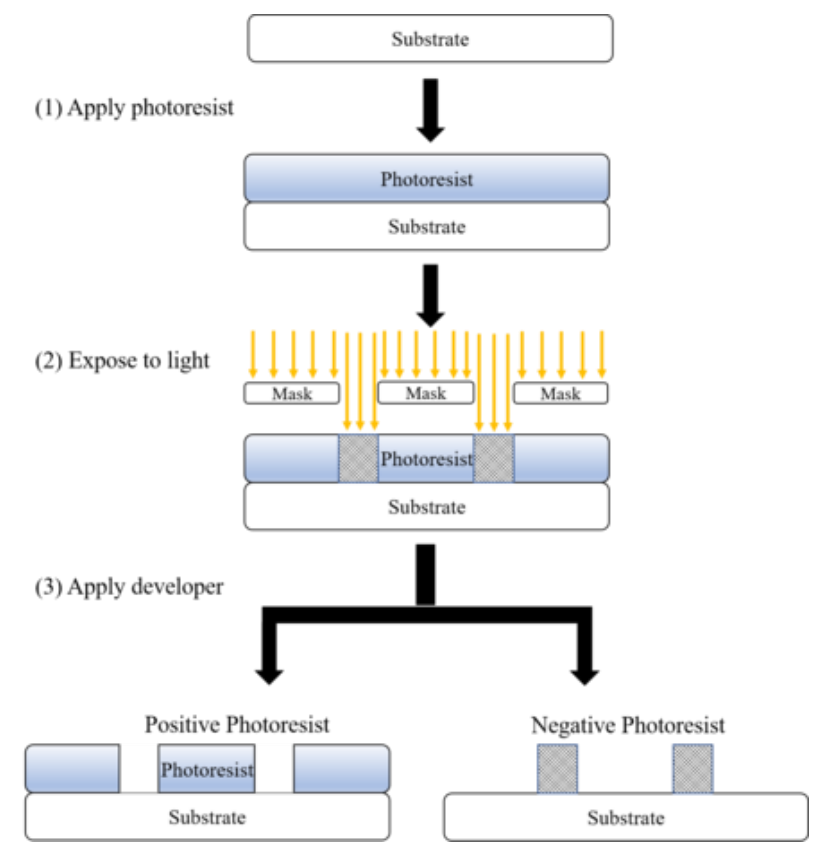

Figura 52: Princípio de fotolitografia positiva e negativa mostrando como a máscara e o fotorresiste podem ser utilizados para construir padrões na superfície das amostras [80].

Observe que o AZ5214 [57] pode ser sensibilizado pela luz UV ${ }^{27}$ [81], de modo que apenas a parte sensibilizada seja removida num processo de revelação positiva, ou o contrário num processo de relação negativa (figura 52). A sensibilidade espectral do AZ 5214 está entre 310 e $420 \mathrm{~nm}$ [57] e a fonte UV sensibilizadora que utilizamos, no LNMS/IFUSP, é uma lâmpada

\footnotetext{
${ }^{25}$ utilizamos o AZ 5214 E.

${ }^{26}$ utilizamos o AZ 400K.

${ }^{27}$ Os comprimentos de onda ultravioleta receberam uma variedade de divisões, dependendo da comunidade de usuários, técnicas de medição e capacidades de instrumentação, podendo variar de 10 - $400 \mathrm{~nm}$.
} 
de $\mathrm{Hg}$ com intensidade de radiação de $16,8 \mathrm{~mW} / \mathrm{cm}^{2}$. Os picos mais fortes do espectro da linha de emissão, do Hg, estão no intervalo 184,45 - 578,2 nm [82] [83]. Portanto essa lâmpada tem uma boa capacidade para sensibilizar o AZ 5214. Esse fotorresiste possui a capacidade de se comportar negativamente após ser sensibilizado por uma breve exposição ao UV ("flood") seguida de um aquecimento apropriado [57]. Os parâmetros que utilizamos para a revelação negativa são mencionados na seção 3.3.1 e os parâmetros que utilizamos para a revelação positiva na seção 3.3.2.

Para melhorar a uniformidade da camada de fotorresiste, ele é espalhado com a ajuda de um spinner (figura 53). Para isso, colocamos fotorresiste na superfície da amostra e a fixamos sobre o rotor do spinner com vácuo. O spinner serve para girar a amostra a $3000 \mathrm{rpm}$ por $40 \mathrm{~s}$ afim de espalhar o fotorresiste e criar uma camada bem fina de espessura mais uniforme (em torno de $1.4 \mu \mathrm{m})$. Quanto maior a frequência de rotação menor a espessura do filme. E quanto menor a amostra maior a chance de se formar bordas com espessuras diferentes e que afetam a uniformidade do processamento. Por isso, apesar das camadas de fotorresiste nunca serem totalmente uniformes, quando depositada sobre uma amostra maior tem mais chances de apresentar uma boa uniformidade, principalmente na região central.

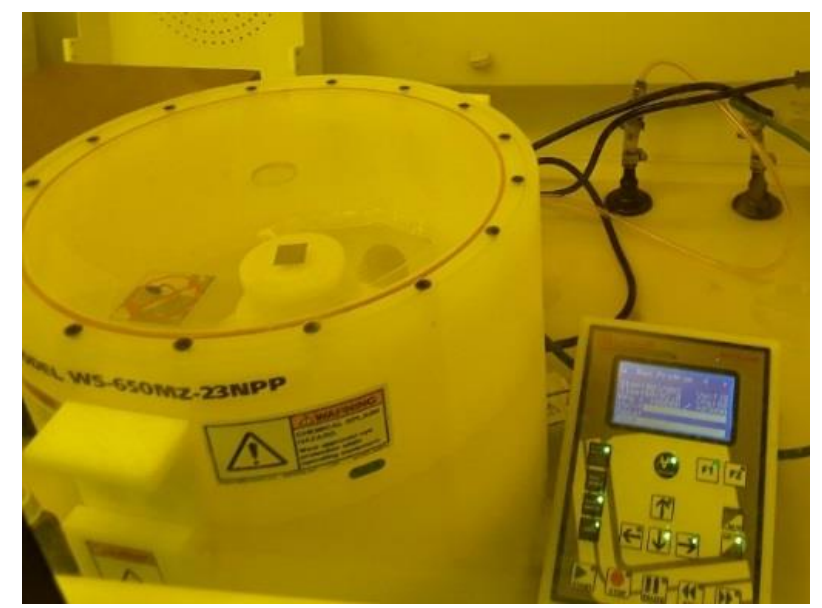

Figura 53: Spinner fechado e pronto para o funcionamento, com a amostra posicionada no centro.

Para melhorar a resistência da camada de fotorresiste aos agentes químicos, fazemos algumas curas (figura 54), de acordo com o nível de resistência que queremos que o fotorresiste tenha a cada etapa e processo. Quando o próximo passo é uma simples revelação ou uma metalização, depois de espalhar o fotoresiste com o auxílio do spinner, colocamos a amostra sobre uma placa aquecedora ("hot plate"), aquecida a $90^{\circ} \mathrm{C}$, por 4 minutos, afim de fazer uma cura rápida, ou "soft baking". Isso faz com que o fotorresiste perca a maioria do seu solvente e que ele fique mais firme e menos pegajoso para poder ficar contato com a máscara sem se deformar. 


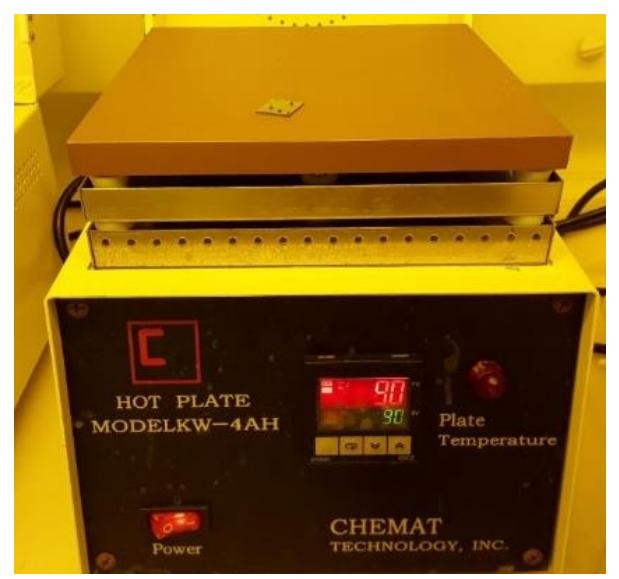

Figura 54: Placa aquecedora ("hot plate") com a amostra 3800 a $90^{\circ} \mathrm{C}$, durante o "soft baking".

Após a cura rápida, sensibilizamos o fotorresiste sobre a amostra com a radiação UV da fotoalinhadora. Nesse processo de sensibilização, uma máscara com o padrão que desejamos formar é posicionada sobre a amostra, previamente coberta com fotorresiste, dentro de uma fotoalinhadora que possui uma fonte de luz UV com intensidade de radiação de $16,8 \mathrm{~mW} / \mathrm{cm}^{2}$. Essa fotoalinhadora possui um sistema de nivelamento pneumático (sistema antivibratório), um sistema de alinhamento com parafusos micrométricos e um sistema óptico (figuras 55 e 56) para poder alinhar padrões com precisão de alguns micrômetros.

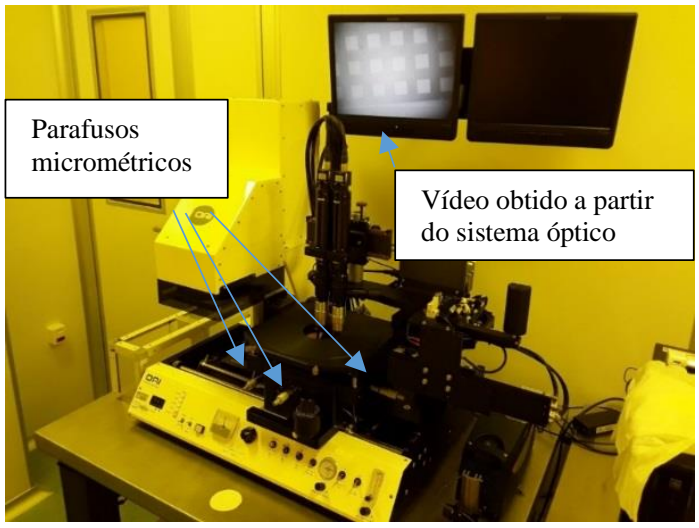

Figura 55: Fotoalinhadora. No monitor, acima da fotoalinhadora, visualizamos o padrão da máscara captado pelo sistema óptico.

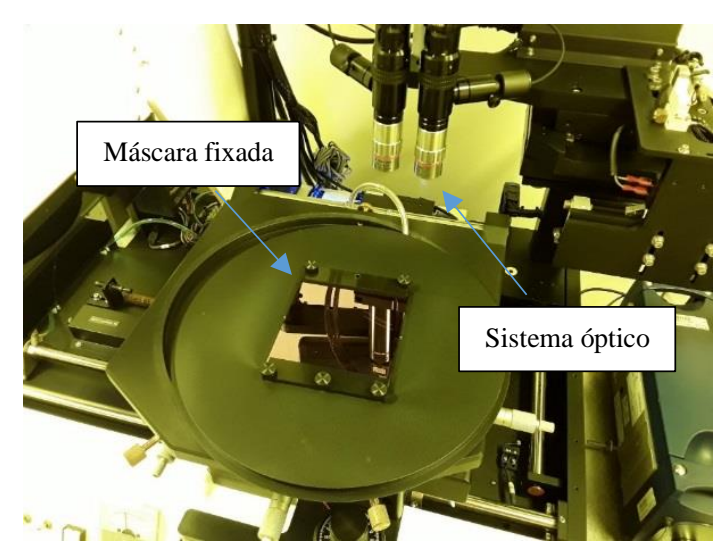

Figura 56: Máscara fixada na Fotoalinhadora.

Nossas amostras foram processadas com 3 máscaras diferentes desenhadas inicialmente pelo grupo da Profa. Patrícia Lustoza de Souza, da PUC-Rio [55], mas que fabricamos em colaboração com o Dr. Carlos César Bof Bufon no LNNano [84] para que pudessem ser usadas em nossa alinhadora que usa máscaras de 4 polegadas:

I) Uma máscara para definir, em cada CS, o contato elétrico superior na camada dopada tipo P (figura 57), formado por várias linhas estreitas ("fingers") metálicas conectadas perpendicularmente a um contato retangular maior ("busbar"), por onde soldamos a CS ao "chip carrier" e ao circuito externo. O número de "fingers" e a largura deles foram variados para que se verificasse o efeito deles sobre a eficiência. 


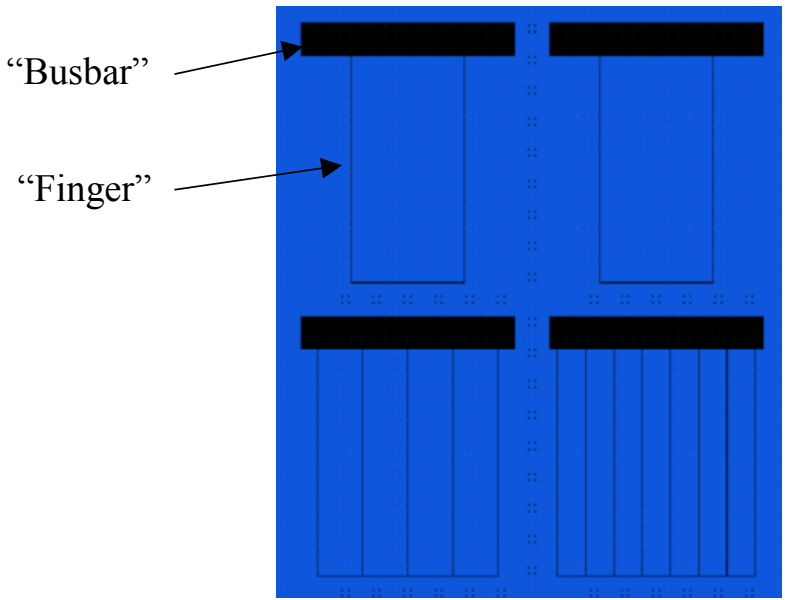

Figura 57: Região da primeira máscara evidenciando alguns "fingers" e a "busbar" de 4 células. Na máscara, apenas as regiões pretas são metalizadas, e a litografia será negativa. A imagem foi obtida pelo software LayoutEditor.

II) Uma segunda máscara para definir por corrosão química o tamanho ${ }^{28}$ físico de cada célula, ou mesa ${ }^{29}$ (figura 58), sendo que essa mesma máscara pode ser também usada para depositar as camadas de metal na parte inferior do dispositivo, sobre a camada dopada do tipo N, para se fazer o segundo contato elétrico.

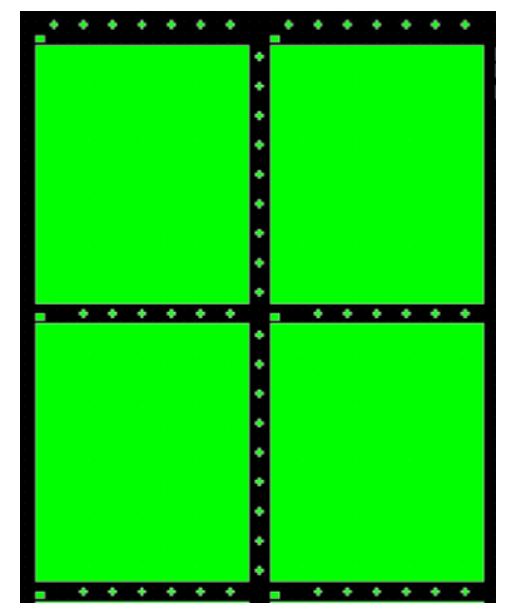

Figura 58: Região da máscara evidenciando algumas mesas. Na máscara, apenas as regiões verdes são metalizadas, e a litografia será positiva. A imagem foi obtida pelo software LayoutEditor.

III) Finamente, a terceira máscara (figura 59) é usada para remover, no final do processamento, a fina camada altamente dopada (“cap layer”), que é necessária para a boa qualidade dos contatos elétricos na camada $\mathrm{P}$, mas que é prejudicial no restante da célula, pois promove uma forte absorção da radiação, o que diminui a eficiência do dispositivo.

\footnotetext{
${ }^{28}$ A (largura; altura) de cada um dos 3 tamanhos de célula em mm é $(2 ; 2,415),(3 ; 3,415)$ e $(5 ; 5,415)$.

29 "mesa" é o nome dado à menor unidade que representa um dispositivo completo, onde podem ser realizados medições e testes para a caracterização, pois cada mesa possui a estrutura completa de camadas epitaxiais de todo o dispositivo. Ou seja, cada mesa forma uma célula solar completa sobre o substrato cristalino.
} 


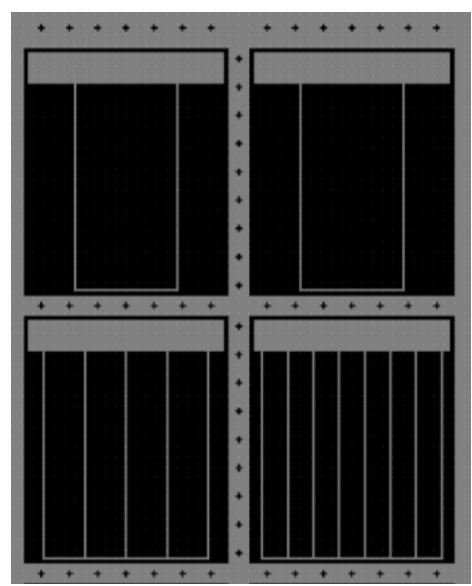

Figura 59: Região da máscara evidenciando a superfície com os contatos superiores e inferiores que devem ser protegidos durante a remoção do "cap layer" dopado. Na máscara, apenas as regiões cinzas são metalizadas, e a litografia será positiva. A imagem foi obtida pelo software LayoutEditor.

Após sensibilizar uma região específica da camada de fotorresiste sobre a amostra com o auxílio da fotoalinhadora e das máscras, a amostra pode ser submetida ao procedimento de revelação. Esse procedimento consiste em mergulhar a amostra numa solução, no nosso caso o AZ400K, para que a região com fotorresiste que foi sensibilizada pela luz UV (no caso de um processo positivo), na etapa anterior, seja dissolvida e removida da amostra. Com esse objetivo, colocamos um pouco da solução AZ400K num pequeno béquer, pegamos a amostra com uma pinça, a imergimos e mexemos levemente, por cerca de $40 \mathrm{~s}$. Após isso, lavamos a amostra, mergulhando e mexendo levemente em 2 béqueres com água DI, por cerca de $10 \mathrm{~s}$ em cada. $\mathrm{E}$ então a secamos rapidamente com um jato de $\mathrm{N} 2$ gasoso. A revelação pode ser feita em etapas, dividindo-se o tempo total de mergulho no AZ400K e mantendo-se o tempo de mergulho na água DI após cada etapa. Ou seja, podem ser realizadas várias revelações parciais com intervalos de tempo de imersão em AZ400K menores. Isso pode ser útil quando se deseja otimizar o processo de revelação. Após cada revelação, a amostra pode ser verificada com o auxílio de um microscópio óptico para conferir se a revelação foi completa ou não.

No caso da revelação positiva, concluída a revelação, a região com o fotorresiste AZ5214 que ficou na sombra, protegida da luz UV pelo padrão da máscara, permanece fixa sobre a amostra como podemos ver na figura 60, onde os quadrados mais escuros (as mesas) são constituídos de uma camada de fotorresiste.

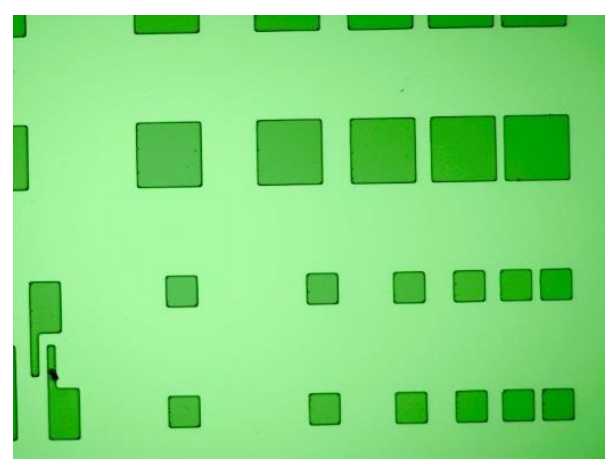

Figura 60: Exemplo de amostra após o procedimento de revelação positiva. Os quadrados maiores possuem $150 \mu \mathrm{m}$ de lado. 
Após a construção do padrão das mesas com fotorresiste, realizamos um ataque químico corrosivo na amostra para defini-las fisicamente. Para prevenir que a região das mesas sofra $o$ efeito do ataque químico, realizamos uma cura mais acentuada, ou "hard baking", aquecendo a amostra a $120^{\circ} \mathrm{C}$ por $20 \mathrm{~min}$, para tornar essa região resistente ao ataque. Para efetuarmos esse ataque químico, preparamos uma solução composta por ácido sulfúrico $\left(\mathrm{H}_{2} \mathrm{SO}_{4}\right)$, peróxido de hidrogênio $\left(\mathrm{H}_{2} \mathrm{O}_{2}\right)$ e água DI nas proporções 1:8:40 em volume. Essa solução é capaz de corroer a parte da amostra que não está protegida pelo fotorresiste (as camadas de GaAs e AlGaAs) a uma taxa de cerca de $1 \mu \mathrm{m}$ por minuto ${ }^{30}$. Ao lado da solução ácida dispomos dois béqueres cheios de água DI para o enxágue da amostra, que deve ser feito imediatamente após a corrosão pela solução ácida. E, imediatamente após as duas etapas de enxague, de cerca de $10 \mathrm{~s}$ cada, deve-se aplicar um jato de $\mathrm{N}_{2}$ gasoso para secagem rápida da amostra, de modo a evitar marcas e outros defeitos indesejáveis. Em seguida, a profundidade da corrosão desejada é confirmada por uma medida da altura das mesas com um perfilômetro (figura 61). Para uma corrosão mais precisa, o ataque químico pode ser realizado em duas etapas ou mais, sendo que em cada etapa a espessura da amostra é medida com o perfilômetro e o perfil analisado via software, como podemos observar na figura 62.

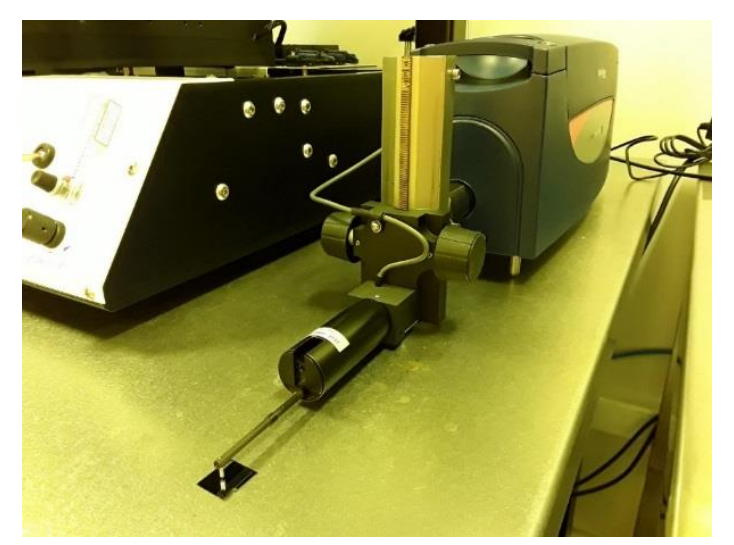

Figura 61: Perfilômetro. A amostra a ser medida está localizada abaixo da ponta de prova.

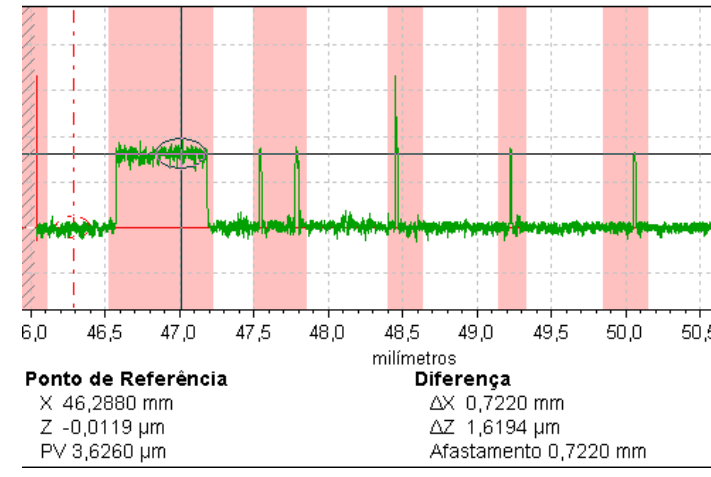

Figura 62: Perfil típico obtido pelo perfilômetro, de um padrão de fotorresiste para definir a "bussbar"e os fingers".

No processamento, usamos a máscara inteira (figura 64) para termos uma grande variedade de células, mas após as primeiras medidas priorizamos as mesas de $2 \mathrm{~mm}$ de lado, ou seja as B3, B4, B5, B6, B7 e B8 (Figura 63) por apresentarem geralmente um desempenho melhor e estarem presentes em maior número.

\footnotetext{
${ }^{30}$ Sempre se deve ter o cuidado de se adicionar o ácido sulfúrico na água por causa da característica exotérmica dessa reação. Se adicionássemos água ao ácido a solução poderia espirrar e causar acidentes.
} 


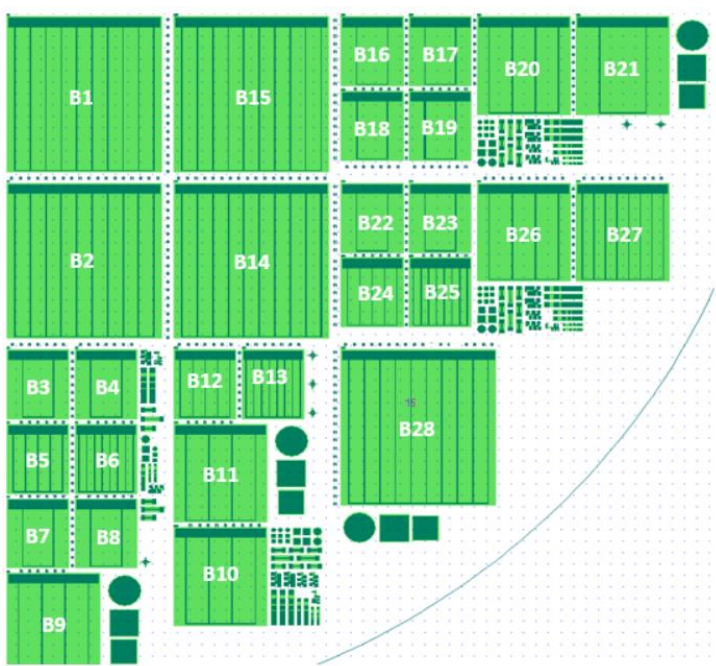

Figura 63: Quadrante utilizado de uma das máscaras ${ }^{11}$. Existe uma grande variedade de tamanho de mesa (2, 3 e $5 \mathrm{~mm})$ e de número de "fingers $(2,5,8$ e 10)".

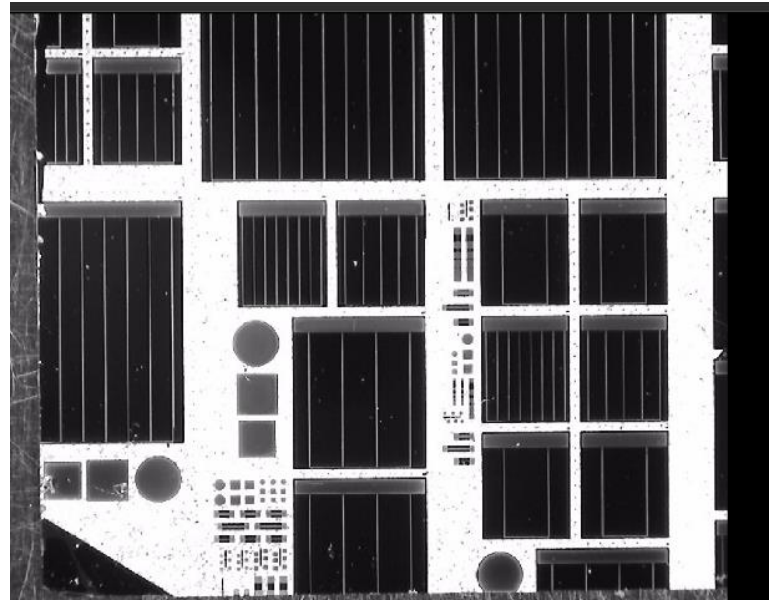

Figura 64: Amostra totalmente processada vista pelo sistema óptico do simulador solar com várias mesas. Cada mesa retangular preta é uma célula solar.

\subsubsection{Fotolitografia Negativa Utilizada para a construção do padrão dos "fingers".}

Para a construção do padrão dos "fingers", que são os contatos superiores de uma célula, utilizamos um processo de litografia negativa. Neste caso, a região da amostra iluminada pela radiação UV, quando uma máscara é colocada sobre ela, é aquela que permanece após a revelação (ao contrário do que acontece no caso positivo, que é o caso convencional). É necessário:

I- $\quad$ Configurar, previamente, o "spinner" para atingir $4000 \mathrm{rpm}$, com uma aceleração de $2000 \mathrm{rpm} / \mathrm{s}$ por $3 \mathrm{~s}$ até que a frequência de rotação se estabilize em $4000 \mathrm{rpm}$, com um tempo total de $40 \mathrm{~s}$ em toda a operação.

II- $\quad$ Fixar a amostra no "spinner" com auxílio do sistema de vácuo localizado no eixo de rotação.

III- cobrir a superfície da amostra com o fotorresiste AZ5214 e girar a $4000 \mathrm{rpm}$ por 40 s.

IV- $\quad$ Fazer o "soft baking" a $90{ }^{\circ} \mathrm{C}$ por $4 \mathrm{~min}$.

V- $\quad$ Fixar a máscara com o padrão dos "fingers" na fotoalinhadora.

VI- Fixar a amostra na fotoalinhadora. A temperatura da sala limpa deve estar em torno de $22{ }^{\circ} \mathrm{C}$, com $45 \%$ de umidade.

VII- Expor por 3,2 sec (nossa lâmpada UV tem uma intensidade de radiação de 16,8 $\mathrm{mW} / \mathrm{cm}^{2}$ ). A intensidade da fonte de luz UV deve ser considerada no cálculo do tempo de exposição. Esse tempo é bem menor que para um processo positivo.

VIII- Aquecer a amostra a $100{ }^{\circ} \mathrm{C}$ por $1 \mathrm{~min} 45$ s na placa aquecedora ("hot plate"). Essa temperatura e tempo são muito importantes e críticos para possibilitar a inversão de imagem que consiste em modificar as propriedades do fotorresiste para que ele passe de um processo positivo para negativo.

Nota: Configuramos a placa para $100{ }^{\circ} \mathrm{C}$ mas medimos a temperatura com um pirômetro e encontramos $98,8^{\circ} \mathrm{C}$. Utilizamos essa configuração. 
IX- Recolocar a amostra na alinhadora, agora sem nenhuma máscara (para fazer o "flood", que é uma exposição da amostra inteira à radiação UV), e expor por 13,4 s.

X- Revelar na solução AZ400 por cerca 17 s(pode variar um pouco!)

XI- Enxaguar em um béquer com água DI por $10 \mathrm{~s}$.

XII- Enxaguar em um outro béquer com água DI por mais $10 \mathrm{~s}$.

XIII- Secar com um jato de $\mathrm{N}_{2}$ gasoso para não deixar a água secar sozinha. Isso evita que surjam manchas sobre as amostras.

Após essa etapa, a amostra será metalizada com ligas metálicas apropriadas para o contato tipo P dos "fingers" (cujo procedimento é descrito mais longe), e então, poderemos submetê-la a uma segunda etapa de processamento para a corrosão das mesas, utilizando a fotolitografia positiva descrita abaixo.

\subsubsection{Fotolitografia Positiva \\ Utilizada para a construção do padrão das mesas}

Para a construção do padrão das mesas, utilizamos o mesmo fotorresiste e a fotolitografia com revelação positiva. Nesse caso, a parte da amostra exposta à radiação UV, quando uma máscara é colocada sobre ela, é aquela que será removida após a revelação. É necessário:

I- $\quad$ Configurar, previamente, o "spinner" para atingir $4000 \mathrm{rpm}$, com uma aceleração de $2000 \mathrm{rpm} / \mathrm{s}$ por $3 \mathrm{~s}$ até que a frequência de rotação se estabilize em $4000 \mathrm{rpm}$, com um tempo total de $40 \mathrm{~s}$ em toda a operação.

II- Fixar a amostra no "spinner" com auxílio do sistema de vácuo localizado no eixo de rotação

III- Cobrir a superfície da amostra com o fotorresiste AZ5214 e girar a 4000 rpm por 40 s.

IV- $\quad$ Fazer o "soft baking" a $90^{\circ} \mathrm{C}$ por 4 min.

V- $\quad$ Fixar a máscara com o padrão das mesas na fotoalinhadora.

VI- Fixar a amostra na fotoalinhadora. A temperatura da sala limpa deve estar em torno de $22,0{ }^{\circ} \mathrm{C}$ com $45 \%$ de umidade.

VII- Expor por $7 \mathrm{~s}$ (nossa lâmpada UV tem uma intensidade de radiação de $16,8 \mathrm{~mW} / \mathrm{cm}^{2}$ ). A intensidade da fonte de luz UV deve ser considerada no cálculo do tempo de exposição.

VIII- Revelar com AZ400 por 1 min e $10 \mathrm{~s}$, aproximadamente (pode variar um pouco!)

IX- Enxaguar em um béquer com água DI por $10 \mathrm{~s}$.

$\mathrm{X}-\quad$ Enxaguar em um outro béquer com água DI por mais $10 \mathrm{~s}$.

XI- Secar com um jato de $\mathrm{N}_{2}$ gasoso para não deixar a água secar sozinha. Isso evita que surjam manchas sobre as amostras.

Fazer o "hard baking" a $120^{\circ} \mathrm{C}$ por 20 min e, após esfriar um pouco, mergulhar a amostra na solução química durante o tempo necessário, como descrito acima, para definir as mesas na amostra.

\subsection{Remoção de óxidos}

A formação de óxidos na superfície da amostra é muito rápida, tendo início logo que a amostra é retirada do sistema MBE e pode prejudicar a construção de contatos elétricos de boa qualidade. O risco é de que esses óxidos atrapalhem a adesão dos filmes metálicos depositados 
assim como a difusão deles no interior da amostra durante a etapa posterior de recozimento térmico para a formação da liga adequada para obter-se contatos ôhmicos de boa qualidade. Portanto, as amostras devem passar por um processo para a remoção desses óxidos. Para isso imergimos a amostra numa solução de HF até que se torne hidrofóbica [85]. Podemos verificar esse efeito facilmente, pois o óxido faz com que a superfície seja hidrofílica e, com isso, a água adere mais facilmente sobre ela. Quando o óxido é removido, o comportamento hidrofóbico da superfície do GaAs predomina e repele a água.

O HF é um ácido altamente corrosivo, capaz de atacar a maioria dos óxidos e silicatos (vidro) e que pode trazer prejuízo muito severo na saúde, se for inalado ou entrar em contato com a pele. Por isso deve ser manipulado com muito cuidado, usando todos os equipamentos de proteção (óculos, avental grosso com manga longa de polietileno, luvas grossas e longas de polietileno, etc.) e armazenado em recipientes especiais, sendo mais comum o uso do polietileno e, melhor ainda, do teflon. No nosso laboratório, utilizamos frascos e béqueres de teflon e pinças de polietileno.

A remoção dos óxidos é feita mergulhando a amostra dentro de uma solução de HF a $10 \%$ (1 parte de HF comercial em 9 partes de água DI) por $5 \mathrm{~s}$ e lavando-a em seguida com água DI. $\mathrm{Na}$ prática, enxaguamos em dois béqueres de água DI por $10 \mathrm{~s}$ em cada, mexendo levemente a amostra. Imersões por tempos muito longos no HF deterioram a camada de fotorresiste. Terminado o processo para a remoção dos óxidos, as amostras são armazenas em recipientes apropriados para evitar danos à camada de fotorresiste e devem ser inseridas o mais rápido possível no ambiente de vácuo da metalizadora, pois a camada de óxidos se forma em poucos minutos.

\subsection{Metalização dos contatos}

Devido à barreira Schottky existente nas junções MS das CSs, há uma alta resistência (com comportamento não ôhmico) à passagem de corrente elétrica. Para diminuir essa resistência, construímos os contatos elétricos depositando uma série de filmes metálicos apropriados para cada tipo de contato. O equipamento que utilizamos para depositar os materiais é um sistema de evaporação por feixe de elétrons (modelo Nexdep da empresa Angstrom Engineering [86] (Figura 65), geralmente chamado de "e-beam" 31 . Ele possui um carrossel com 6 posições contendo cada uma um material (em nosso caso $\mathrm{Au}, \mathrm{Ti}, \mathrm{Ge}, \mathrm{Pt}, \mathrm{Ni}$ ) que pode ser aquecido pela incidência de um feixe de elétrons de alta energia que derreterá localmente a carga selecionada e gerará assim um fluxo daquele material na câmera de vácuo onde se encontram as amostras.

31 “E-beam” é uma abreviação para "electron-beam” (do inglês, significando feixe de elétrons). 


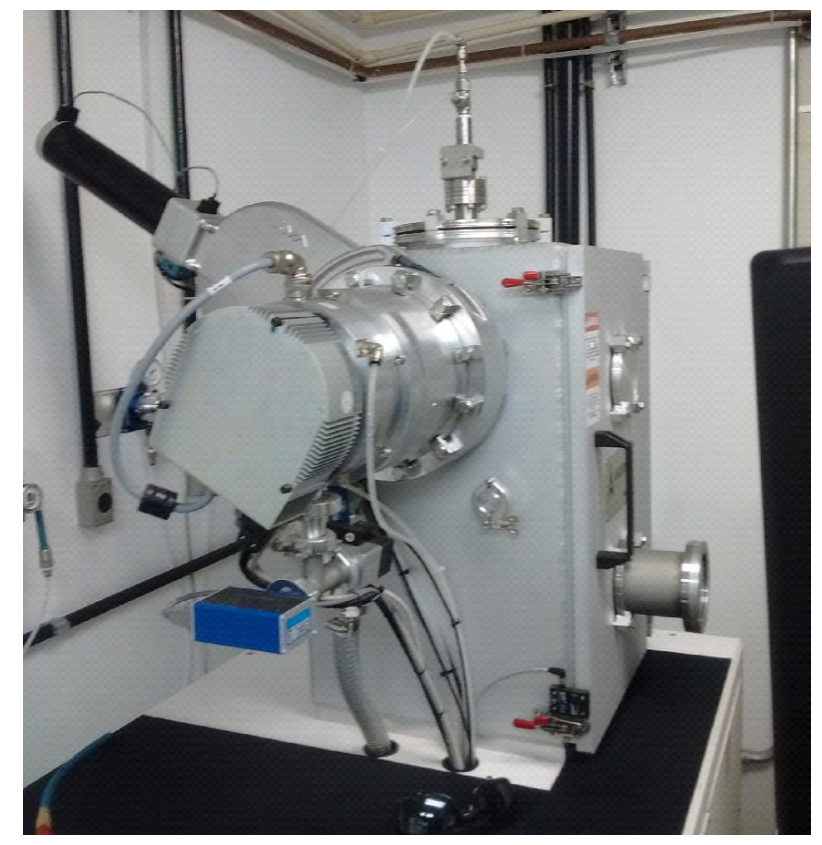

Figura 65: O sistema de deposição por feixe de elétrons, modelo Nexdep da empresa Angstrom Engineering.

Para gerar esse feixe, uma corrente passa por um filamento de tungstênio que o leva ao aquecimento por efeito Joule e à consequente emissão de elétrons. Uma alta tensão é aplicada entre o filamento e o carrossel, afim de acelerar esses elétrons, na presença de um campo magnético forte que os desvia e os concentra em um único feixe na direção da carga de material selecionada no carrossel. Quando ele atinge o material, a energia do feixe é transferida para o material, fazendo com que ele evapore (ou sublime) na câmara e seja depositado sobre as amostras posicionadas acima do carrossel, viradas para baixo (Figura 67). 

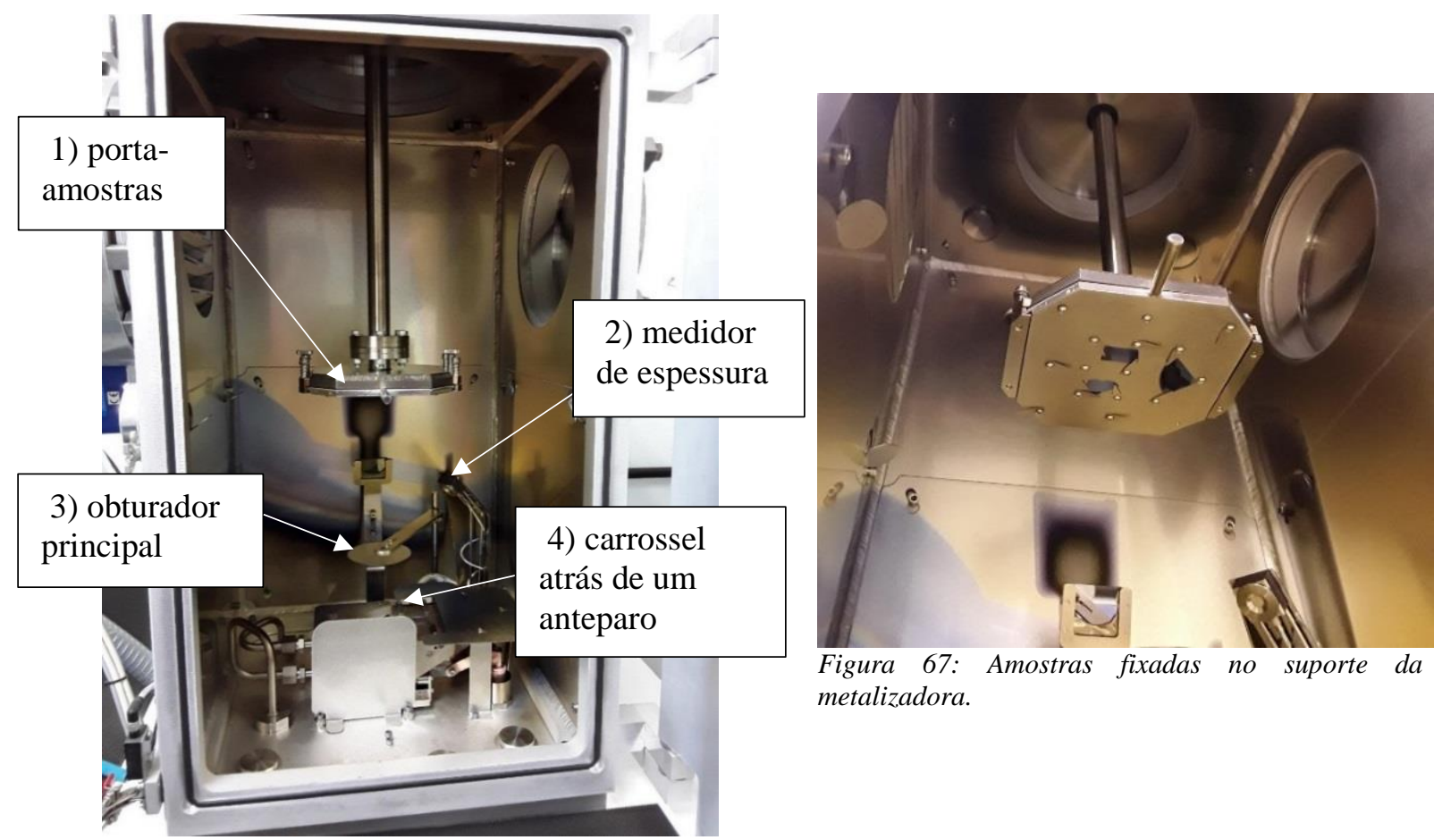

Figura 66: Parte interna da metalizadora, mostrando 1) o porta-amostras, 2) o medidor de espessura, 3) o obturador principal e 4) o carrossel atrás de um anteparo.

As vantagens em se utilizar a evaporação por feixe de elétrons é que o feixe é capaz de aquecer localmente materiais em altíssimas temperaturas sem precisar aquecer a carga inteira nem o cadinho, como numa evaporadora térmica convencional, o que limita as impurezas liberadas no processamento e melhora a qualidade dos filmes. Além disso, o uso de um carrossel motorizado permite que vários elementos sejam depositados sequencialmente sem a necessidade de abrir o sistema. Durante a deposição, o porta-amostras é refrigerado por um sistema de água gelada para minimizar o aquecimento das amostras (e do fotorresiste) pela radiação térmica oriunda da carga, e a taxa de deposição do material é monitorada em tempo real por um oscilador de quartzo. Um computador controla todas as funções de vácuo (bomba mecânica, bomba turbo molecular, várias válvulas) e de deposição (material escolhido, potência do filamento, espessura dos filmes), o que possibilita uma deposição totalmente automatizada uma vez que os materiais e espessuras dos filmes foram inseridos no programa. Como temos dois tipos diferentes de contato em nossas CSs, para as camadas dopadas do tipo $\mathrm{N}$ e tipo $\mathrm{P}$, precisamos de duas ligas diferentes de materiais para diminuir a barreira Schottky. Para a diminuição da barreira do contato tipo N, utilizamos, sequencialmente, camadas finas de $\mathrm{Ni}$, Ge e Au com respectivas espessuras de 25,55 e $150 \mathrm{~nm}$. O níquel promove uma boa adesão das camadas seguintes e impede que o ouro difunda demais na amostra e coloque os dois contatos do dispositivo em curto. $O$ germânio serve para dopar o GaAs e baixar a resistência de contato, enquanto que o ouro é usado por último por ser excelente condutor e inerte no ar, o que facilita a microssolda e a conexão do dispositivo a um circuito externo. Já para a diminuição da barreira Shottky do contato tipo $\mathrm{P}$, utilizamos, na sequência, filmes de Ti, Pt e Au com espessuras de 20, 100 e 200 nm, respectivamente. 


\subsection{Lift off}

Após a metalização, os filmes metálicos estão cobrindo a amostra inteira, sendo que eles só devem permanecer nas regiões específicas onde serão realizados os contatos elétricos. $\mathrm{O}$ "lift off" consiste em remover o filme que foi depositado sobre as regiões cobertas por fotorresiste. Para isso, deixamos a amostra mergulhada em acetona por certa de 30 min (Figura 68). A acetona dissolve e remove o fotorresiste levando junto o filme metálicoque está sobre ele. Removemos o restante do filme metálico que por ventura ainda esteja grudado na amostra, limpando cuidadosamente com um cotonete e acetona (Figura 69). Em seguida aplicamos um jato de acetona, tendo o cuidado para não deixá-la secar sobre a amostra, o que acarretaria em manchas indesejáveis. Em seguida, aplicamos um jato de álcool isopropílico e, finalmente, secamos com $\mathrm{N}_{2}$ gasoso. A Figura 70 mostra um pedaço da amostra observado num microscópio ótico, após passar por um tratamento térmico,ser fixado em um suporte e ter recebido microssoldas com fios de ouro de $25 \mu \mathrm{m}$ de diâmetro.

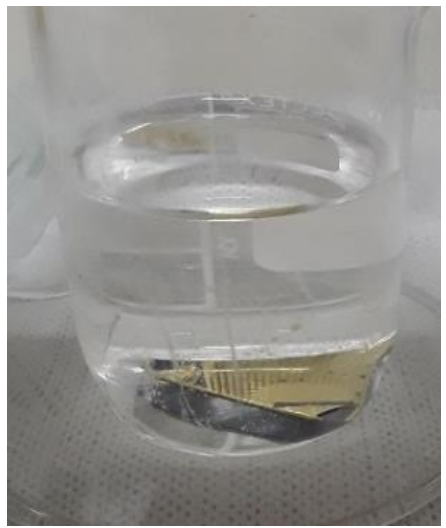

Figura 68: Amostra mergulhada em acetona durante o "lift off".
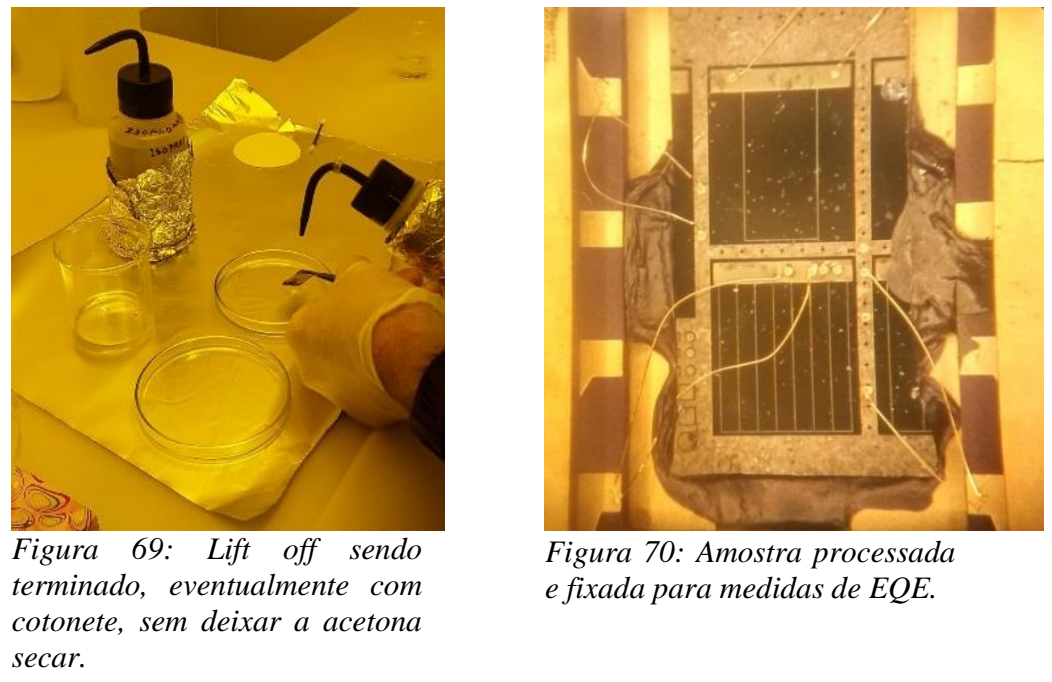

Figura 70: Amostra processada e fixada para medidas de EQE.

\subsection{Tratamento térmico dos contatos}

Após o "lift off", as camadas metálicas dos contatos tipo $\mathrm{N}$ devem passar por um tratamento térmico para formar uma liga que proporcione um contato ôhmico de boa qualidade. A técnica utilizada consiste em realizar um recozimento rápido da amostra (RTA, "rapid thermal annealing") num ambiente controlado com a temperatura adequada. Esse tratamento proporciona uma difusão dos metais para dentro da amostra e a formação de uma liga que reduz consideravelmente a altura da barreira Schottky. Como a temperatura necessária é geralmente alta $\left(400\right.$ a $\left.600{ }^{\circ} \mathrm{C}\right)$, o tempo de recozimento deve ser curto, para evitar uma difusão exagerada dos metais e um curto entre os contatos, o que necessita um sistema de aquecimento e de resfriamento da amostra extremamente rápido, com taxa de até $100^{\circ} \mathrm{C}$ por segundo [87], [88].

O equipamento disponível para realizar os tratamentos térmicos no nosso laboratório, o modelo AccuThermo AW610 da empresa AllWin21, é um sistema de processamento térmico rápido (RTP, "rapid thermal processing"), que usa radiação visível de alta intensidade (21 lâmpadas halógenas de $1 \mathrm{~kW}$ cada) para aquecer amostras de até 6 polegadas de diâmetro por períodos curtos de tempo, em temperaturas controladas de até $1200{ }^{\circ} \mathrm{C}$. Essas características, combinadas com o design da parede fria da câmara, proporcionam vantagens em relação aos fornos convencionais [89], pois é possível maior controle sobre a temperatura da amostra, com 
variação de $\pm 1{ }^{\circ} \mathrm{C}$ [90]. O sistema é controlado por computador através do software Allwin21 RTAPRO [91], que permite o controle e diagnóstico do processamento. Além disso, permite a criação de receitas para o controle automatizado da temperatura e do fluxo dos gases envolvidos (figura 71).

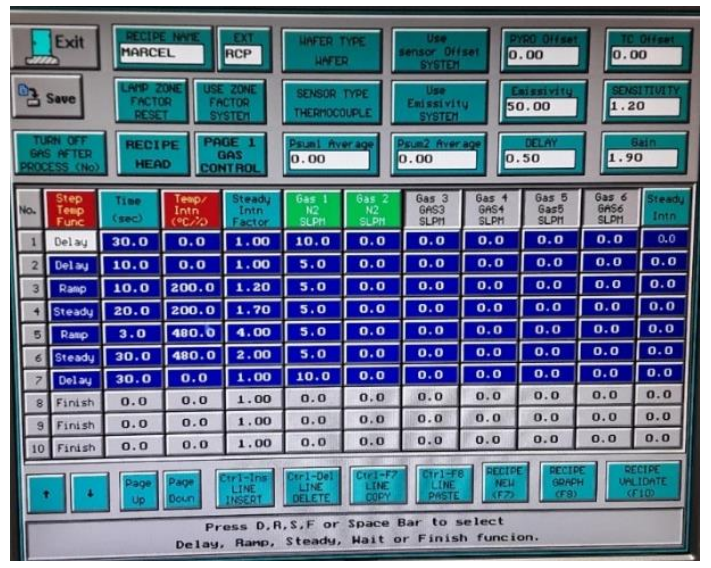

Figura 71: Exemplo de uma receita armazenada. Em cada linha são configurados os parâmetros de cada passo como tempo, temperatura e fluxo de gases.

Com o processamento por RTA, podemos afetar as propriedades fisioquímicas da amostra, ativando dopantes, mudando as propriedades das interfaces filme/filme ou filme/substrato, alterando as propriedades dos filmes depositados, além de poder reparar danos ou influenciar a difusão e a concentração dos dopantes ao longo das amostras. As amostras são colocadas sobre um substrato de Si que repousa sobre um suporte de quartzo (figura 72) que desliza no interior de uma câmara de quartzo cercada pelas lâmpadas halógenas e pelo sistema de refrigeração. Na câmara de quartzo circula um fluxo de N2 para evitar que o aquecimento seja realizado na presença de ar ambiente, o que oxidaria imediatamente as amostras e prejudicaria a qualidade dos contatos.

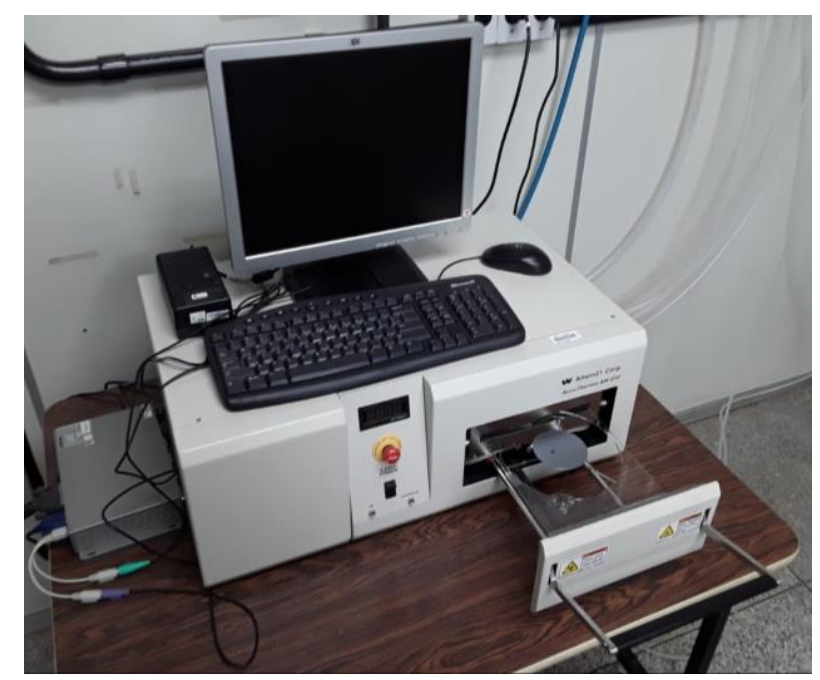

Figura 72: Sistema de recozimento rápido (RTA). 
Nas amostras produzidas para esse trabalho, o tratamento térmico é realizado quando tanto o contato superior tipo $\mathrm{P}$ como o inferior tipo $\mathrm{N}$ já estão depositados sobre a amostra, pois o contato tipo $\mathrm{N}$ precisa do recozimento, mas o contato tipo $\mathrm{P}$ não (e o tratamento não influencia a qualidade dele). Assim, aplicamos a técnica RTA apenas com o objetivo de formar uma liga apropriada com os filmes de $\mathrm{Ni}, \mathrm{Ge}$ e $\mathrm{Au}$ depositados durante a metalização para a formação do contato tipo $\mathrm{N}$ (figuras 73 e 74 ).

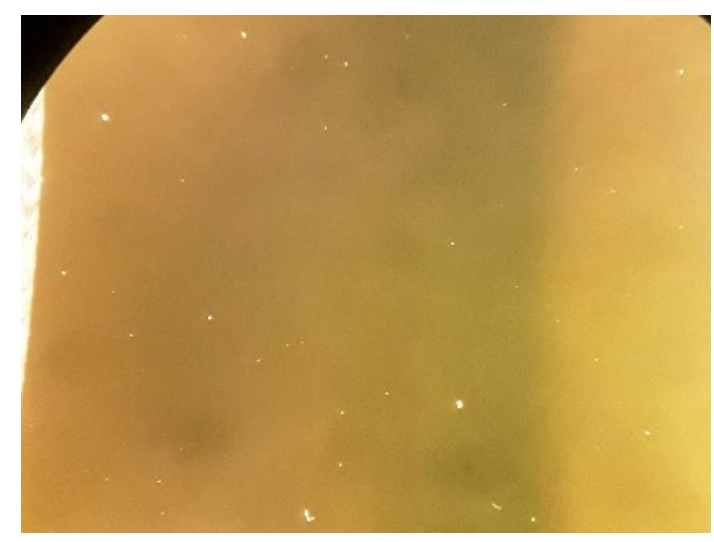

Figura 73: Imagem de uma Amostra de GaAs que recebeu as camadas de $\mathrm{Ni}$, Ge e Au, antes do recozimento térmico $(R T A)$.

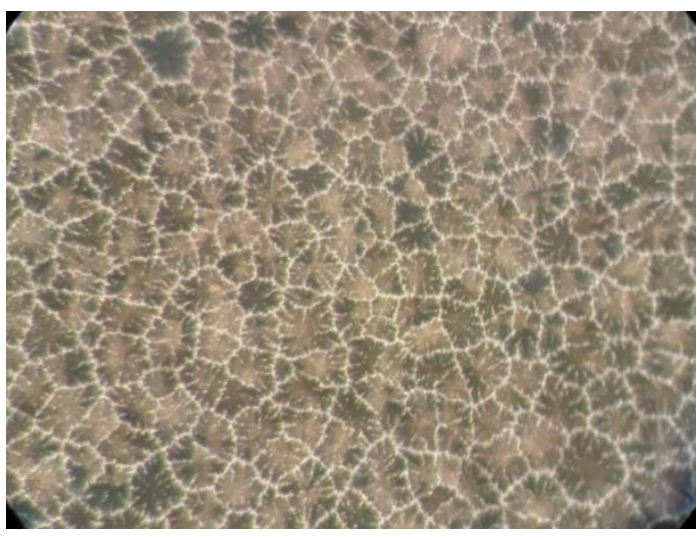

Figura 74: Estrutura do mesmo filme metálico após o recozimento térmico.

A rotina que utilizamos consiste em aquecer a amostra de 0 a $200{ }^{\circ} \mathrm{C} \mathrm{em} 10 \mathrm{~s}$, em seguida aquecer de 200 a $520^{\circ} \mathrm{C}$ em $3 \mathrm{~s}$ e manter a $520^{\circ} \mathrm{C}$ por $30 \mathrm{~s}$. Após isso a fonte de potência que gera o aquecimento é cortada e é a refrigeração do sistema que se encarrega de resfriar a amostra o mais rapidamente possível. Finalizado o tratamento, o sistema fornece os gráficos da figura 75 que informam as configurações planejadas nas receitas e o que efetivamente ocorreu durante o tratamento. Um indício visual muito útil, para confirmar que houve difusão dos metais para dentro da amostra e a formação de uma liga, é que a morfologia do filme muda consideravelmente, parecendo uma estrutura de casca de laranja possuindo uma coloração bem diferente daquela do filme de ouro original (figuras 73 e 74). 


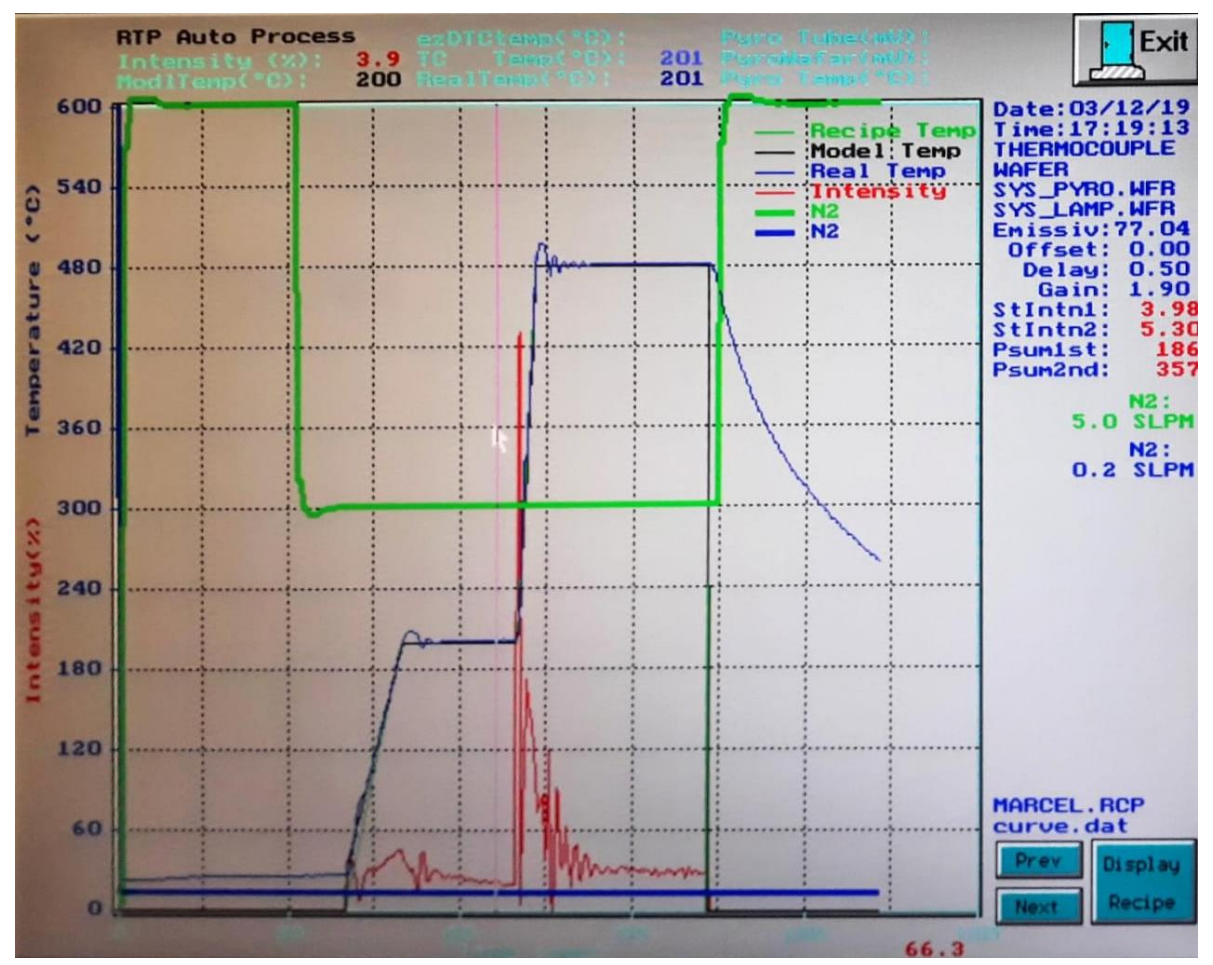

Figura 75: Gráfico fornecido pelo computador do processo de recozimento térmico (RTA). A curva verde fina representa a rotina de temperatura planejada. A curva azul fina corresponde à temperatura real durante o recozimento. A curva verde grossa corresponde ao fluxo de $N_{2}$. A curva vermelha corresponde à potência aplicada nas lâmpadas para fornecer o perfil de temperatura desejado.

Essa é a última etapa para a construção das CSs básicas desenvolvidas nesse trabalho. Portanto, após essa etapa, as amostras podem ser caraterizadas diretamente num simulador solar ou passar por outros tipo de medidas tais como a conferência da qualidade dos contatos (TLM), ou medidas de responsividade espectral (nesse caso, precisa-se realizar microssoldas como no caso da figura 70 . 


\subsection{Probe station}

Após o tratamento térmico dos contatos, precisamos verificar seu efeito sobre a resistividade dos contatos. Para isso, utilizamos uma "probe station" da empresa Cascade Microtetech (figura 76) operando na temperatura ambiente (essa empresa foi adquirida em 2016 pela empresa Form Factor) [92] [93]. A "probe station", acoplada a um analisador de parâmetros semicondutores (modela B1500A, da empresa Agilent) funciona basicamente como um multímetro para estruturas muito pequenas, ou seja, as pequenas pontas de prova (figura 77) são posicionadas nos locais das amostras entre os quais desejamos verificar quedas de tensão, corrente, resistência, capacitância etc. No caso das medidas de resistência, aplicamos uma ddp variável na estrutura, entre os dois pontos que queremos medir (Figura 78), e verificamos a corrente gerada. Todas as medidas são automatizadas pelo analisador, são realizadas em alguns segundos, e os resultados são mostrados numa tela na forma de gráficos.

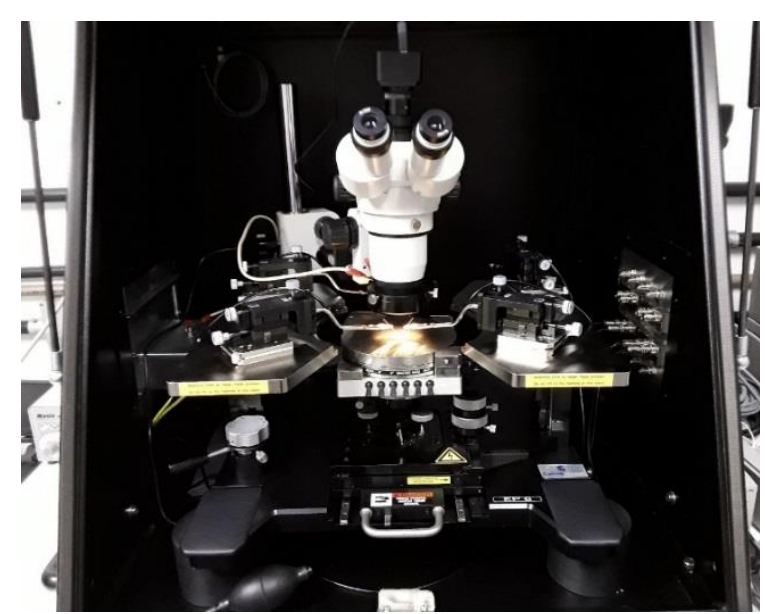

Figura 76: "Probe station" modelo EP6 da empresa Cascade Microtetech, correspondente ao modelo EPS150 Triax da empresa Form Factor.

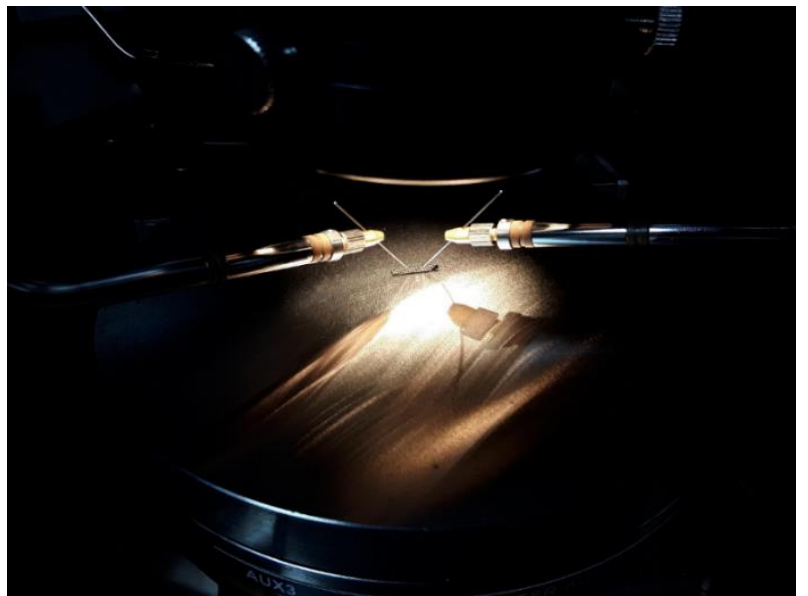

Figura 77:Detalhe das pontas de prova da "probe station" tocando uma amostra. A intensidade da iluminação sobre a amostra pode ser ajustada. 


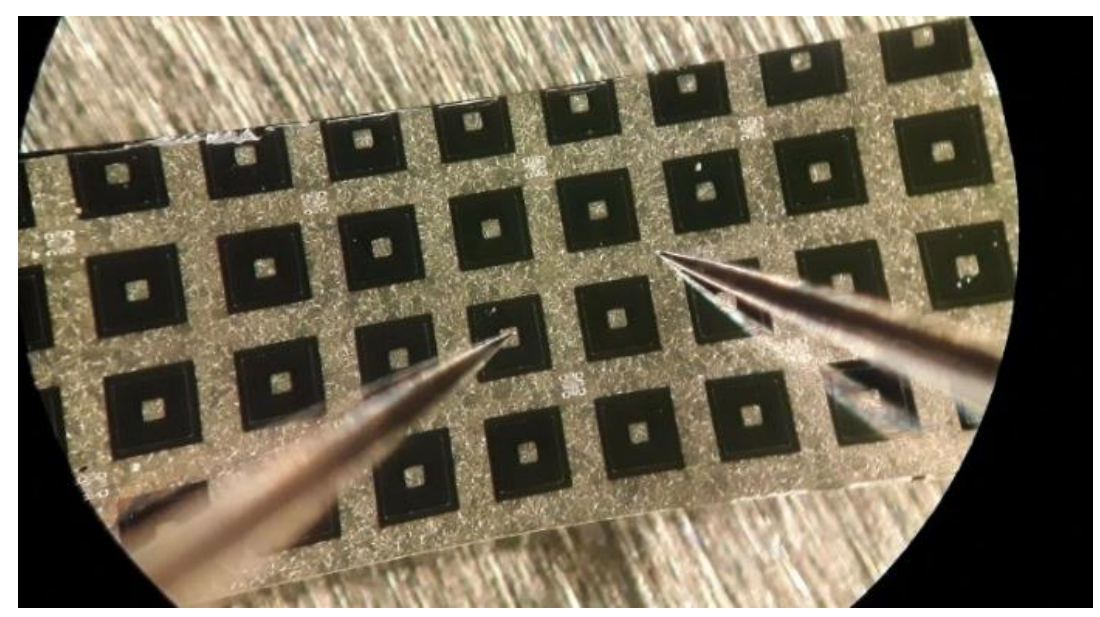

Figura 78: CS obtida com a utilização da máscara utilizada para fabricar fotodetectores ${ }^{32}$. Detalhe das posições das duas pontas de prova para testar uma mesa (quadrado preto). Uma ponta de prova encosta no contato superior que está sobre a mesa e a outra encosta no contato inferior comum a todas as mesas.

A amostra pode ser iluminada através de uma fonte com intensidade ajustável, e é possível isolar completamente a "probe station" para que não haja interferência da iluminação externa sobre a amostra (figura 79) e para minimizar a influência do ruído elétrico externo.

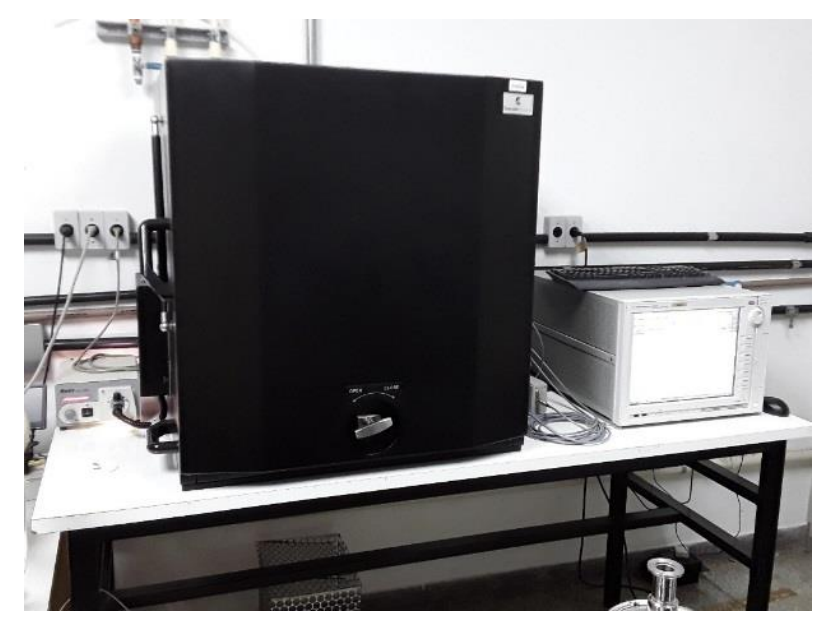

Figura 79: "Probe station" totalmente isolada afim de se evitar o efeito da luz ambiente e de ruídos elétricos externos. À direita, pode-se observar o analisador de parâmetros semicondutores.

A escolha adequada dos metais e das espessuras usadas para o contato tipo $\mathrm{N}$ das nossas CSs, assim como a influência positiva do recozimento térmico rápido, podem ser vistos nas figuras 80 e 81 que mostram uma curva $\mathrm{I} \times \mathrm{V}$ (corrente versus voltagem) de 2 contatos isolados do tipo $\mathrm{N}$ na parte inferior da CS, antes (figura 80) e depois (figura 81) do recozimento. Pode-se observar claramente que, antes do recozimento, a curva é altamente não linear, enquanto que, depois do recozimento, temos um comportamento ôhmico. A saturação da corrente acima de 1

\footnotetext{
${ }^{32} \mathrm{Na}$ fase inicial dos trabalhos, ainda não estavam disponíveis as máscaras apropriadas com o padrão de "busbar" e "fingers", cedidas mais tarde pela PUC-Rio. Por isso, foi fabricada uma amostra com a máscara que era utilizada para a produção de fotodetectores. Com essa máscara não é possível construir os contatos do tipo $\mathrm{N}$ e tipo $\mathrm{P}$ separadamente.
} 
mA é uma proteção prevista pelo analisador ("compliance") para evitar que correntes altas circulem no dispositivo e o destruam (o valor pode ser mudado à vontade e mesmo ser eliminado se precisar).

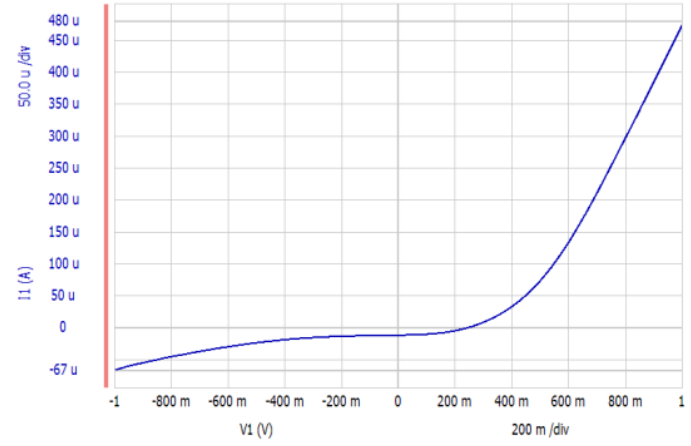

Figura 80: Curva I $\times$ V entre 2 contatos isolados do tipo $N$, antes do recozimento térmico, apresentando comportamento não ôhmico.

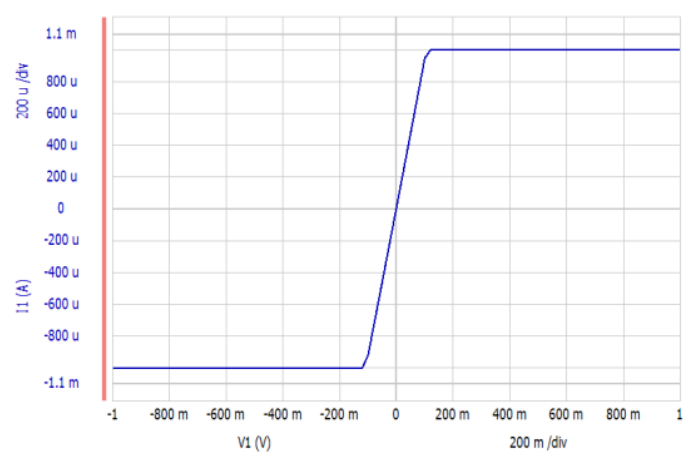

Figura 81: Curva I $\times$ V entre 2 contatos isolados do tipo $N$, depois do recozimento térmico, apresentando comportamento ôhmico.

\subsection{Técnica TLM}

Após a verificação, com o auxílio da "probe station", de que conseguimos construir contatos ôhmicos, ainda precisávamos conferir se a resistência deles era baixa o suficiente para não prejudicar o desempenho das CSs. Uma técnica bastante utilizada para essa finalidade é a técnica TLM [94] [95] [96] [97] que consiste basicamente em depositar pequenos contatos regulares separados por uma distância crescente e medir com a "probe station" a resistência entre cada par de contatos vizinhos com 4 pontas de prova (figura 82) de maneira a eliminar a resistência dos cabos que pode, em alguns casos, ser maior que a resistência dos próprios contatos.

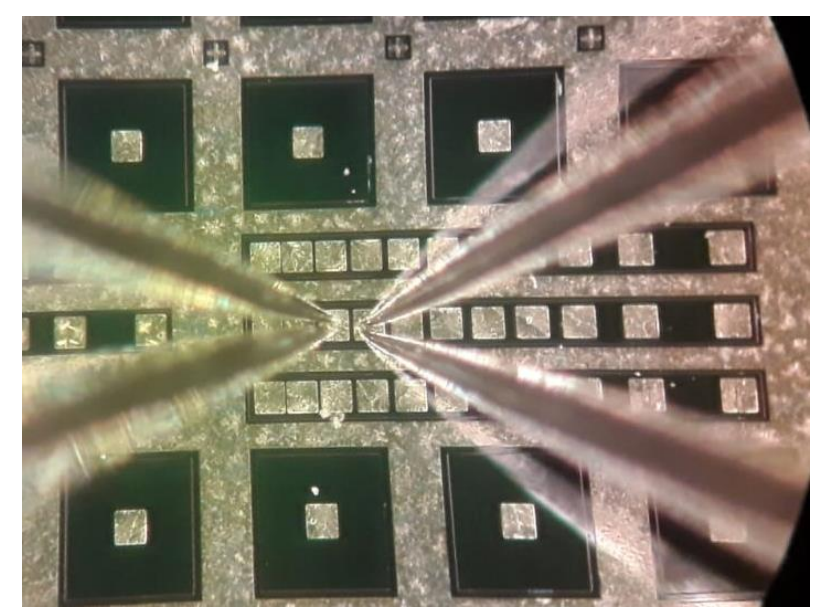

Figura 82: Amostra processada, com padrão TLM, para teste de resistividade, sendo medida com 4 pontas de prova numa "probe station". 
Na figura 83 são mostrados os parâmetros relevantes relacionados à técnica TLM.
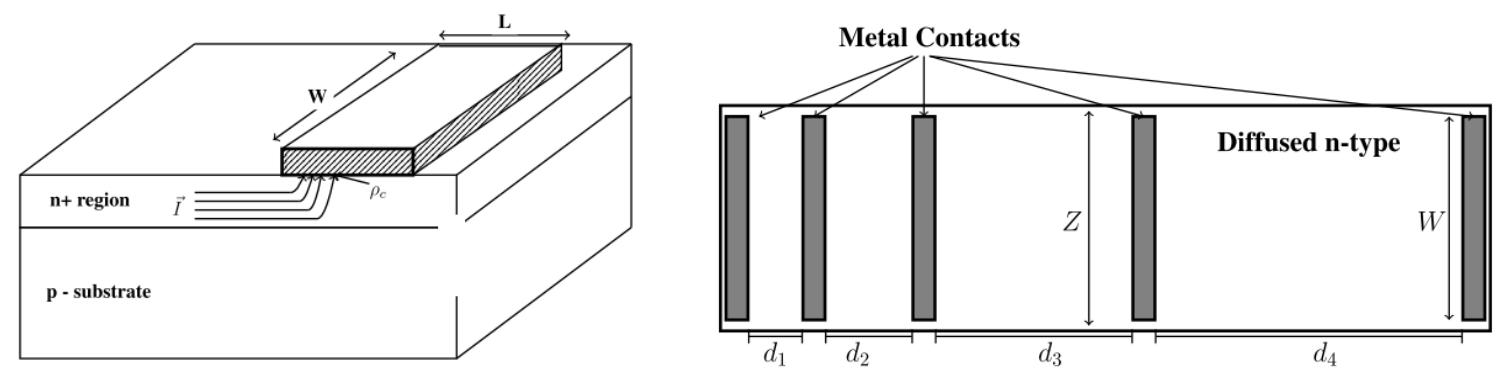

Figura 83: Parâmetros relevantes para a técnica TLM [97].

A resistência $R_{c}$ dos contatos e a resistência de folha da amostra $R_{S H}$ podem ser encontradas montando-se um gráfico da resistência medida entre cada par de contatos em função da distância entre eles (figura 84).

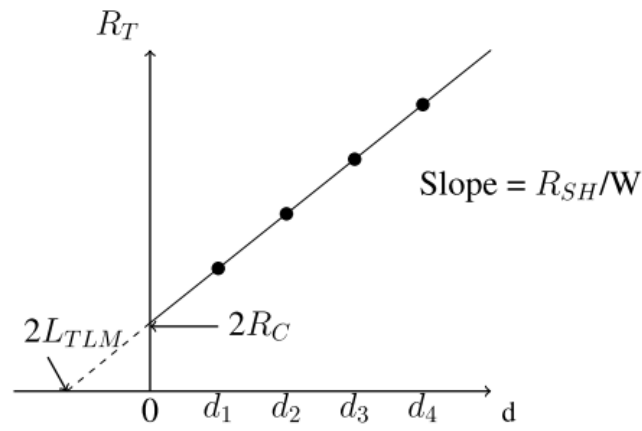

Figura 84: A curva da resistência total medida $R_{T}$ em função da distância entre dois contatos vizinhos do padrão TLM nos proporciona o valor da resistência de cada contato $R_{C}$ e o valor da resistência de folha ${ }^{33} R_{S H}$ da amostra.

Do gráfico (

Figura 84), obtemos a equação:

$$
R_{T}=2 R_{C}+\left(\frac{R_{S h}}{W}\right) d
$$

onde W e d são, respectivamente, a largura dos contatos e a distância (crescente) entre 2 contatos vizinhos. Outro parâmetro importante na utilização da técnica é o comprimento TLM, chamado $L_{T L M}$. No gráfico (figura 84), a resistência de contato $\mathrm{R}_{\mathrm{c}}$ é a metade do valor da abcissa quando interceptada pelo prolongamento da reta. $L_{T L M}$ é a distância que a corrente avança na interface entre a amostra e o contato até atravessá-la e está relacionado com a resistividade $\rho c$ do contato, crescendo à medida que a resistividade cresce (figura 85).

${ }^{33}$ Essa resistência de folha é a resistência em um plano paralelo à superfície, dentro do substrato. 


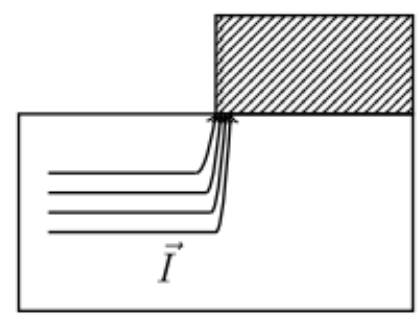

(a) Low $\rho_{c}$

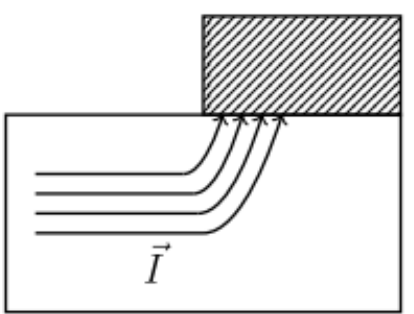

(b) High $\rho_{c}$

Figura 85: Relação entre o fluxo de corrente, o comprimento LTLM e a resistividade $\rho_{c}$ do contato.

Essa relação ${ }^{34}$ por ser expressa por [53] [97] [95]:

$$
L_{T L M}=\sqrt{\frac{\rho_{c}}{R_{S H}}}
$$

Se substituirmos $d=-2 L_{T L M}$ na equação (63), a análise do TLM fornece os resultados:

$$
\begin{gathered}
L_{T L M}=\frac{R_{C} W}{R_{S h}}=\frac{R_{C}}{\alpha} \\
R_{S h}=\alpha W
\end{gathered}
$$

onde $\alpha$ é o coeficiente angular da equação (63), isto é, da reta da figura 84.

Com o auxílio das equações (65) e (66), podemos obter o valor da resistividade:

$$
\rho_{C}=R_{S h} L_{T L M}^{2}=\frac{\left(\mathrm{R}_{\mathrm{c}} \cdot \mathrm{W}\right)^{2}}{R_{S H}}
$$

onde os valores de $\mathrm{R}_{\mathrm{c}}$ e $\mathrm{R}_{\mathrm{SH}}$ podem ser obtidos da figura 84, e o valor de W é definido no padrão dos contatos usados para se fazer as medidas. Observe que não podemos encontrar a resistividade $\rho_{C}$ simplesmente dividindo a resistência $\mathrm{R}_{\mathrm{C}}$ pela área do contato, pois a corrente não atravessa toda essa superfície, além de sua intensidade cair exponencialmente com a distância da borda mais próxima da origem da corrente.

\subsection{Microscopia de Força Atômica}

Na produção das CS-QDSKs, temos que conhecer as características dos QDs produzidos pela técnica MBE para que possamos relacioná-las com as medidas obtidas nos procedimentos de caracterização. A técnica de microscopia de força atômica (AFM, "atomic force microscopy") permite um estudo das características dos QDs, tais como suas dimensões, geometria, densidade, e proporção de QDs relaxados e QDs não relaxados. A vantagem no emprego dessa técnica é a possibilidade de investigar a superfície sem uma preparação prévia e à temperatura ambiente. $\mathrm{O}$

\footnotetext{
${ }^{34}$ Detalhes da origem da equação (64) podem ser encontrados nas páginas 34 a 37 da referência [97].
} 
equipamento utilizado nesse trabalho para a aplicação da técnica AFM é o modelo ICON da empresa Bruker [98]. A técnica de medição por AFM funciona a partir da interação de uma ponta com a amostra a ser investigada (figura 86). Essa ponta é fixada sobre um suporte ("cantilever") que pode ser deslocado nas 3 direções do espaço por um sistema piezelétrico. Sobre esse suporte incide um laser que é refletido e incide sobre um detector fotoelétrico possuindo 4 quadrantes de detecção independentes. No modo de contato, a ponta é encostada levemente contra a superfície da amostra e realiza uma varredura da amostra numa região predeterminada. Como a ponta está em contato com a amostra, ela vai seguir o relevo da superfície, flexionando o "cantilever" e mudando o sinal detectado pelos quadrantes do detector. Um sistema de retroalimentação atua sobre o deslocamento vertical da ponta para manter a força de contato constante, assim como o valor de leitura do detector. Essa tensão aplicada no sistema piezelétrico na direção vertical fornece uma informação topográfica da amostra em cada posição da ponta, possibilitando assim a geração de imagens da superfície investigada. Para diminuir o desgaste da ponta que fica permanentemente em contato com a amostra, costuma-se usar um outro modo, chamado de modo intermitente (ou "Tapping", que é uma expressão patenteada pela empresa Bruker) onde o "cantilever" fica oscilando na sua frequência de ressonância e a ponta de prova só toca levemente a amostra na extremidade da oscilação, o que reduz consideravelmente a sua interação com a amostra. Quando a ponta está longe da amostra, a amplitude de oscilação possui um valor específico, que será modificado quando ela estará em contato intermitente com a superfície, o que fornecerá o critério de retroalimentação para o sistema.

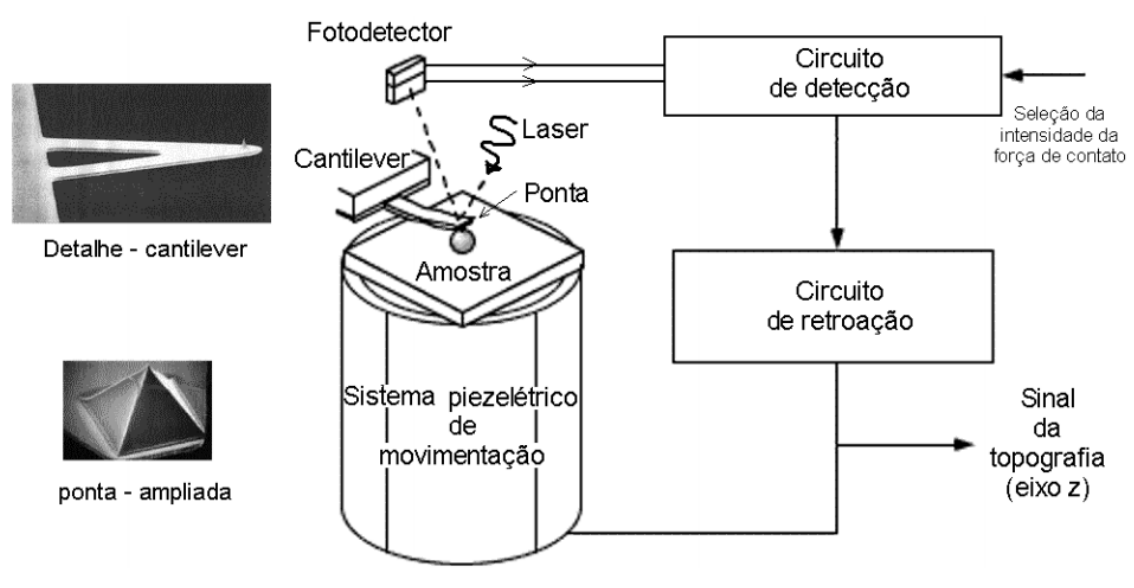

Figura 86: Diagrama dos componentes do sistema AFM [99]. No caso específico dessa figura, o "cantilever" é fixo e é a amostra que é deslocada pelo sistema piezelétrico.

Como a técnica AFM é essencialmente uma técnica de análise de superfície, é necessário que as estruturas a serem observadas estejam no alcance da ponta. Por essa razão, amostras contendo pontos quânticos cobertos por outras camadas de materiais, como é o caso em nossas CSs, não podem ser analisadas. Nesse caso, é necessário crescer uma amostra suplementar, nas mesmas condições experimentais que o dispositivo, na qual a última camada depositada (os pontos quânticos) deverá ser a camada de interesse a ser analisada por AFM.

\subsection{Fotoluminescência}

Uma maneira eficiente de investigar as propriedades ópticas de materiais semicondutores é realizando medidas de fotoluminescência. Nessa técnica, um feixe luminoso monocromático 
(geralmente vindo de um laser) incide na amostra e excita elétrons da banda de valência do material, promovendo-os até a banda de condução e deixando buracos na banda de valência. Esse processo só ocorre caso a energia dos fótons incidentes seja maior que o valor do gap do material. Na banda de condução, esses elétrons fotogerados podem relaxar, ou seja, perder energia até que cheguem no fundo da banda onde podem então recombinar radiativamente com os buracos que também migraram para o topo da banda de valência. Quando isso ocorre, fótons com energia correspondente ao gap do material são emitidos e podem ser coletados e analisados para determinar o gap do material ou as energias de confinamento do sistema caso haja também nanoestruturas presentes na amostra (figura 87). Em um material real, além do gap do material e dos níveis de energia relacionados com eventuais nanoestruturas presentes na amostra (pontos quânticos, por exemplo), existem também os níveis criados por impurezas e defeitos que podem gerar sinal de luminescência e, portanto, fornecer informações importantes. A amostra é geralmente colocada num criostato óptico (com janela), submetida à radiação de um laser, e a luminescência é recolhida por um sistema de lentes e focalizada na entrada de um monocromador, que a decomporá nos seus comprimentos de onda constituintes, que serão enviados na saída e analisados por um detector (de Ge, Si ou uma fotomultiplicadora de GaAs em função do tipo de amostra). O sinal elétrico do detector é lido por um "lockin" (acoplado a um "chopper" localizado no caminho óptico do laser) e enviado a um computador de controle (figura 88) que montará um gráfico da intensidade da luminescência em função do comprimento de onda.

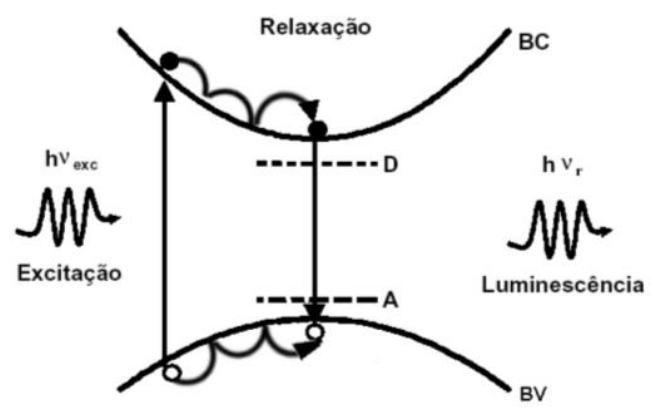

Figura 87: Processo de excitação e emissão num experimento de fotoluminescência [99]. Caso haja impurezas não intencionais ou dopagem (intencional) no material semicondutor, haverá, além do gap, também níveis de energia relacionados com essas impurezas doadoras (tipo n) ou aceitadoras (tipo p).

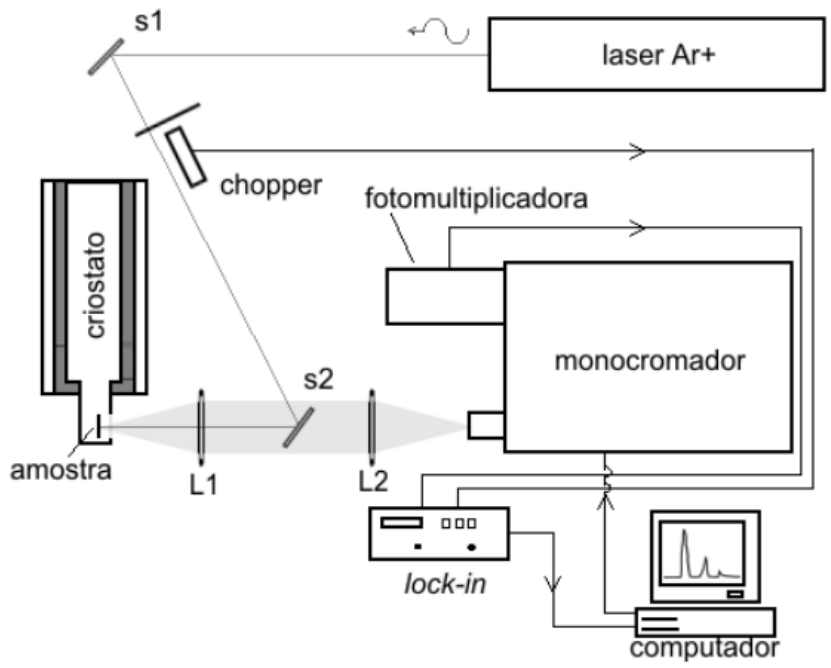

Figura 88: Esquema de um arranjo experimental de fotoluminescência [99]. 


\subsection{Absorção e eficiência quântica}

As medidas de fotoluminescência fornecem informações úteis a respeito da qualidade das amostras, do valor do gap dos materiais e de alguns níveis de energia relacionados com nanoestruturas, mas carecem de informações quantitativas e de informações mais diretas a respeito dos níveis de energia eventualmente presentes. Uma das formas de se obter essas informações é realizar medidas de absorção. Em vez de incidir sobre uma amostra uma radiação monocromática fixa e analisar o espectro da radiação emitida no processo de recombinação entre 2 níveis de energia, como é feito no experimento de luminescência, num experimento de absorção faz-se o contrário: incide-se sobre a amostra uma radiação monocromática de comprimento de onda variável e mede-se o sinal elétrico gerada na própria amostra toda vez que essa radiação consegue excitar portadores entre dois níveis de energia. Além disso, quando a radiação incidente é calibrada, isto é, quando se sabe a intensidade de cada comprimento de onda que incide na amostra, pode-se determinar a eficiência quântica (número variando de 0 a 1) dessas transições que consiste em saber quantos pares elétron-buraco são gerados para cada fóton incidindo sobre a amostra (eficiência quântica externa) ou absorvido pela amostra (eficiência quântica interna). No caso de uma célula solar, a eficiência quântica externa [100] [101] pode ser calculada a partir da responsividade espectral das fotocélulas, que é definida como:

$$
R_{\lambda}=\frac{I_{\lambda}}{P_{\lambda}}
$$

onde $I_{\lambda}$ é a corrente gerada pela CS devido à incidência de fótons com comprimento de onda $\lambda \mathrm{e}$ potência óptica $P_{\lambda}$. A relação entre a $R_{\lambda}$ e a $E Q E(\lambda)$ pode ser expressa como:

$$
\operatorname{EQE}(\lambda)=\frac{R_{\lambda}}{\lambda} \cdot \frac{A_{d}}{A_{C S}} \cdot \frac{h c}{e} \approx \frac{R_{\lambda}}{\lambda} \cdot \frac{A_{d}}{A_{C S}} \cdot 1240
$$

onde $A_{d}$ e $A_{C S}$ são as áreas ópticas (descontando a área dos contatos) do detector de referência (para calibrar a intensidade de cada comprimento de onda incidente) e da CS, respectivamente.

Para as medidas de absorção ${ }^{35}$ (responsividade) [102], usamos uma lâmpada halôgena (que possui um espectro largo, cobrindo o visível, parte do UV e do infravermelho) e, após modular a sua intensidade com um "chopper", selecionamos um comprimento de onda específico fazendo-a passar por um monocromador. Na saída, após passar por um dos filtros da roda de filtros (para evitar difrações de ordens superiores), um sensor calibrado de Si mede a intensidade de cada comprimento de onda. Um computador recebe as informações de um lock-in, conectado ao sensor e ao chopper, ajudando a coletar os dados e fornecendo assim, uma curva espectral da intensidade absoluta da radiação produzida pela fonte (figura 89).

\footnotetext{
${ }^{35}$ Mais detalhes do nosso experimento podem ser consultados no trabalho do Leonardo [102] desenvolvido durante a sua iniciação científica no nosso laboratório.
} 


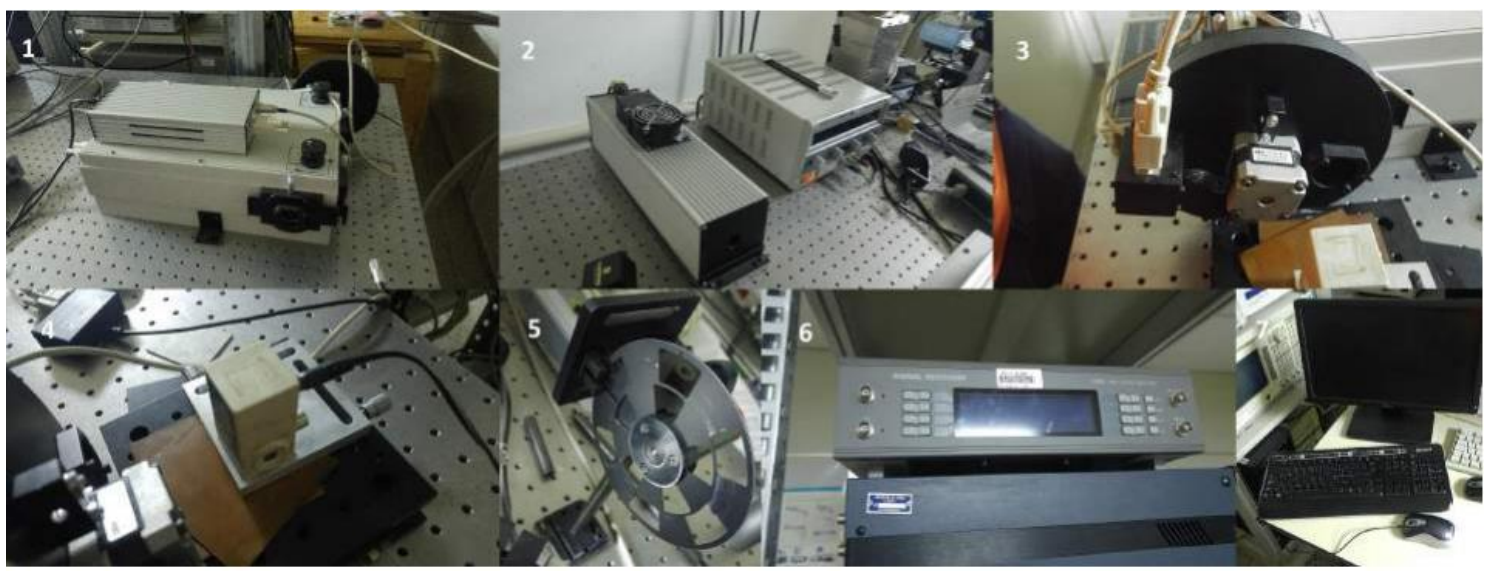

Figura 89: Arranjo experimental do experimento de absorção. 1 - Monocromador; 2 - Fonte de radiação infravermelha ("globar") que em nosso caso foi substituída por uma lâmpada halógena que possui um espectro mais intenso no visível; 3 - Roda de Filtros; 4 - Sensor de silício; 5 - "Chopper”; 6 - "Lock-in"; 7 - Computador [102].

Em seguida, o sensor é removido e a CS a ser testada (Figura 90) é instalada no mesmíssimo lugar para se ter certeza de receber a mesma quantidade de radiação. O experimento é então feito novamente, mas desta vez o sinal é oriundo da CS, é medido e comparado (dividido) com o sinal do sensor de Si. Como esse último veio de fábrica com uma curva de calibração própria, podemos assim determinar a responsividade da nossa célula solar e, em seguida a eficiência quântica dela a partir dos cálculos mostrados acima.

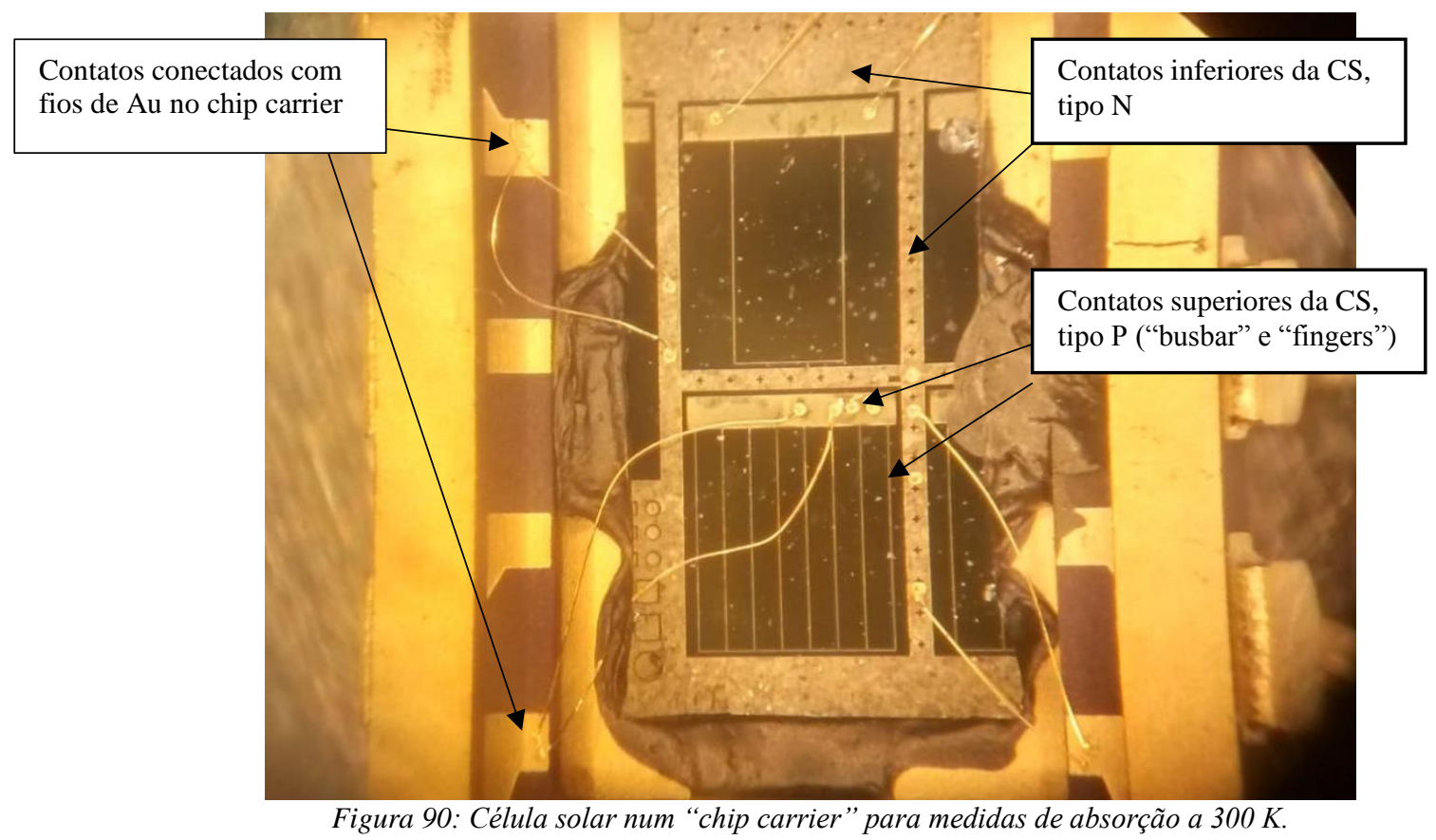

Página| 93 


\subsection{Simulador solar}

A principal técnica de caracterização das células solar consiste em submetê-las à radiação solar e avaliar uma série de parâmetros que refletirão o desempenho geral delas. Para que isso seja feito em condições controladas e reprodutíveis, costuma-se usar um simulador solar. Com ele podemos obter várias figuras de mérito, como a eficiência $\eta$, a corrente de curto-cirtuito ISC, a voltagem de circuito aberto $\mathrm{V}_{\mathrm{OC}}$, o fator de preenchimento $\mathrm{FF}$, o ponto de tensão e de corrente para a potência máxima, $V_{\max }$ e $I_{\max }$, respectivamente, assim como as resistências "shunt" $\mathrm{R}_{\text {shunt }} \mathrm{e}$ de série $R_{\text {série. }}$ O simulador utilizado nesse trabalho (figuras 91 e 92) é da classe AAA da empresa Abet Technologies [103] (a mais exigente em relação à qualidade do espectro produzido, da homogeneidade espacial e da estabilidade temporal) e foi escolhido para atender todos os tipos de materiais e tamanhos de células solares que são produzidos no LNMS/IFUSP. Esse simulador é integrado a um sistema computacional que facilita muito a tomada de medidas e os gráficos.

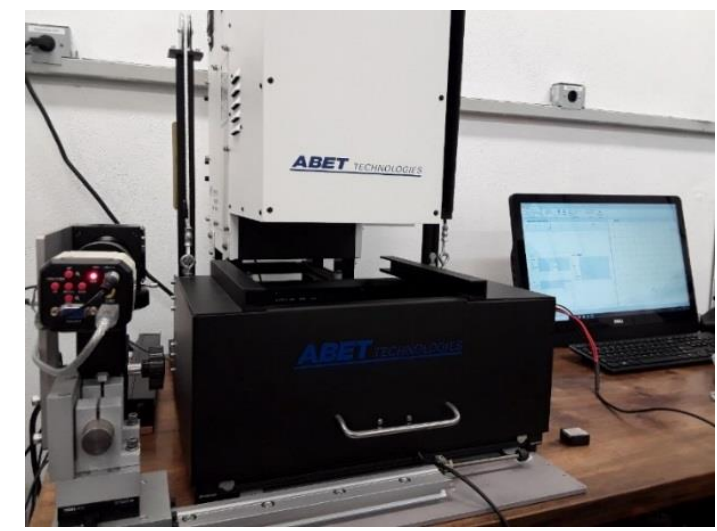

Figura 91: Simulador solar utilizado nesse trabalho.

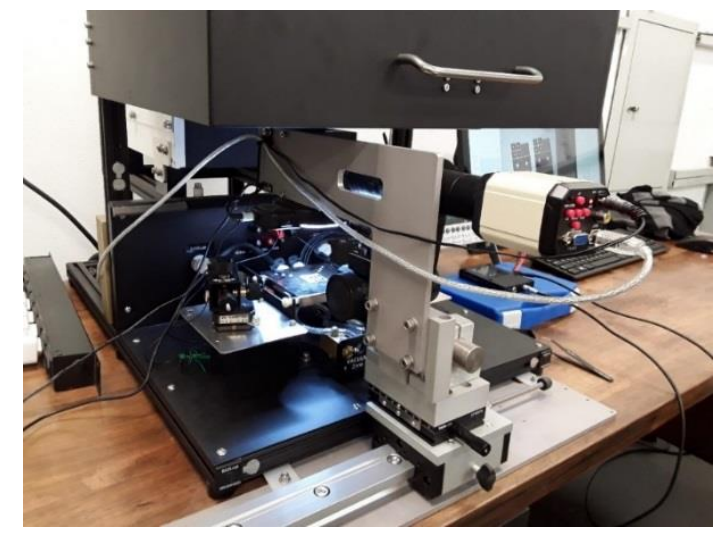

Figura 92: Sistema óptico do simulador solar usado para posicionar as duas agulhas sobre os contatos dos dispositivos

No interior do simulador, uma lâmpada de Xe (Figura 93) é energizada por uma fonte de alimentação e é localizada no foco de um refletor elíptico que coleta a radiação e a foca sobre um homogeneizador óptico que, em conjunto com a uma lente condensadora, cria uma iluminação uniforme [104]. 


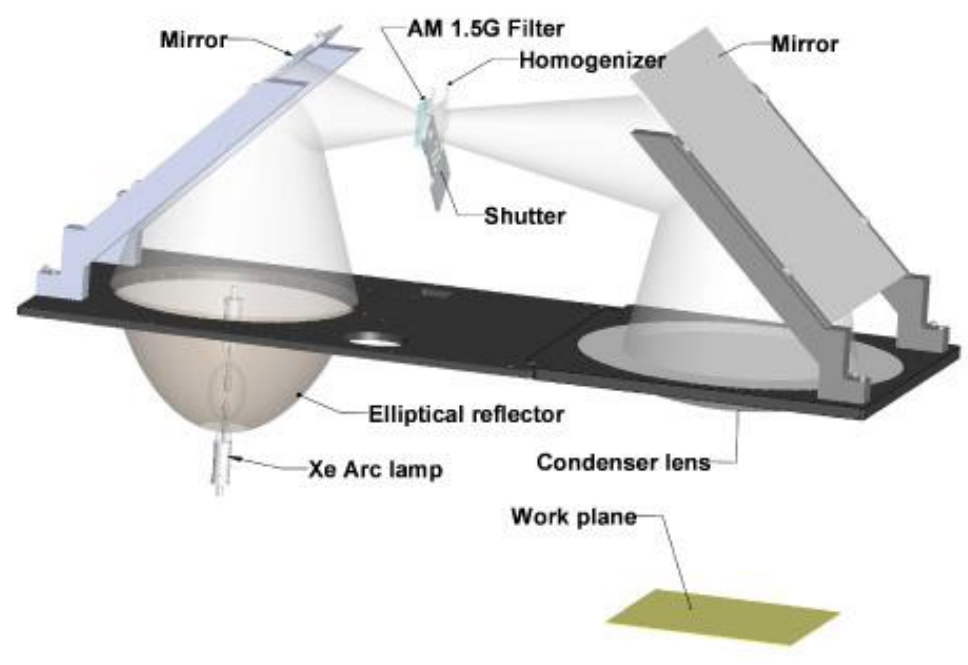

Figura 93: Apresentação esquemática da parte interna do Simulador Solar da Abet Technologies [104].

Espelhos são usados para dobrar o caminho óptico e tornar o instrumento mais compacto. Os elementos de modelagem de espectro, como o filtro AM 1.5G, estão localizados imediatamente antes do conjunto do homogeneizador para assegurar que a modelagem espectral seja reprodutível em todo o plano de trabalho. O obturador ótico está localizado após os filtros espectrais e o homogeneizador, de modo que esses elementos ópticos e suas montagens possam chegar a um equilíbrio térmico após o aquecimento inicial do sistema e fornecer um desempenho estável a cada ciclo de abertura do obturador. A temperatura da amostra é mantida a $25^{\circ} \mathrm{C}$, que é o valor padrão normalmente utilizado para as medidas, com o auxílio de um "chiller".

Após calibrar a irradiância total do sistema com uma célula solar comercial calibrada [105], ajustando a potência da lâmpada para que a irradância seja de $1000 \mathrm{~W} / \mathrm{m}^{2}$ (segundo o padrão AM1.5G), o sistema de controle automatizado [106] realiza uma curva $\mathrm{I} \times \mathrm{V}$, monta o gráfico e fornece os principais parâmetros mencionados acima (figura 94). O sistema possibilita também a análise da CS no escuro, sem a incidência de radiação, o que fornece informações úteis sobre a própria junção $\mathrm{PN}$, tais como o fator de idealidade (n) e a corrente reversa $\left(\mathrm{I}_{0}\right)$, conforme mostrado na figura 95.
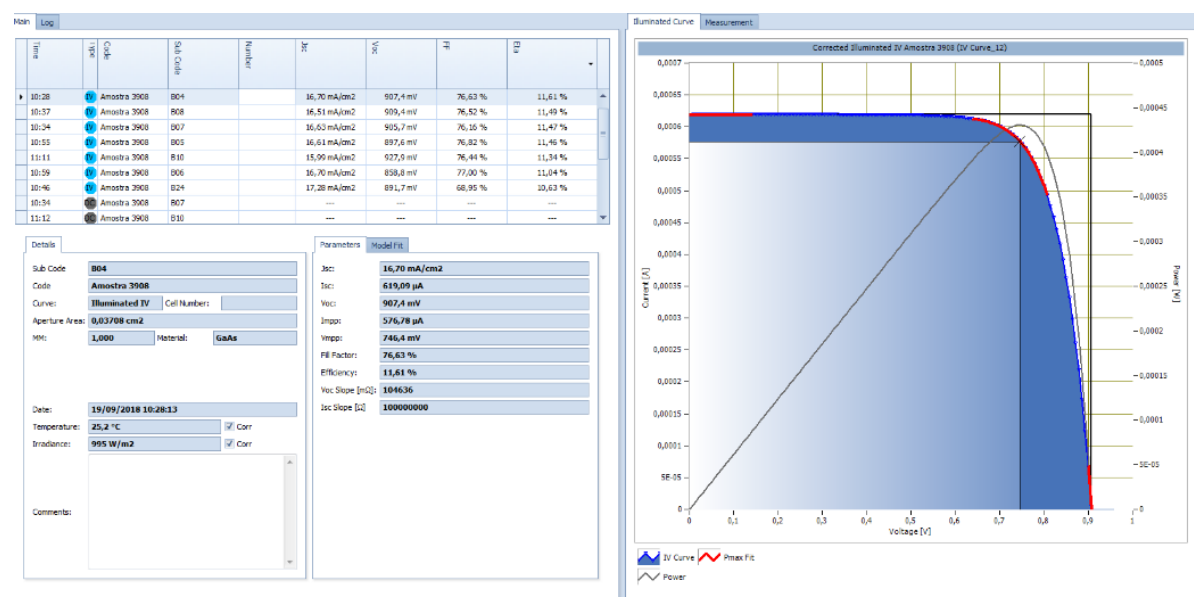

Figura 94: Exemplo de resultados fornecidos de maneira automática pelo simulador solar. 


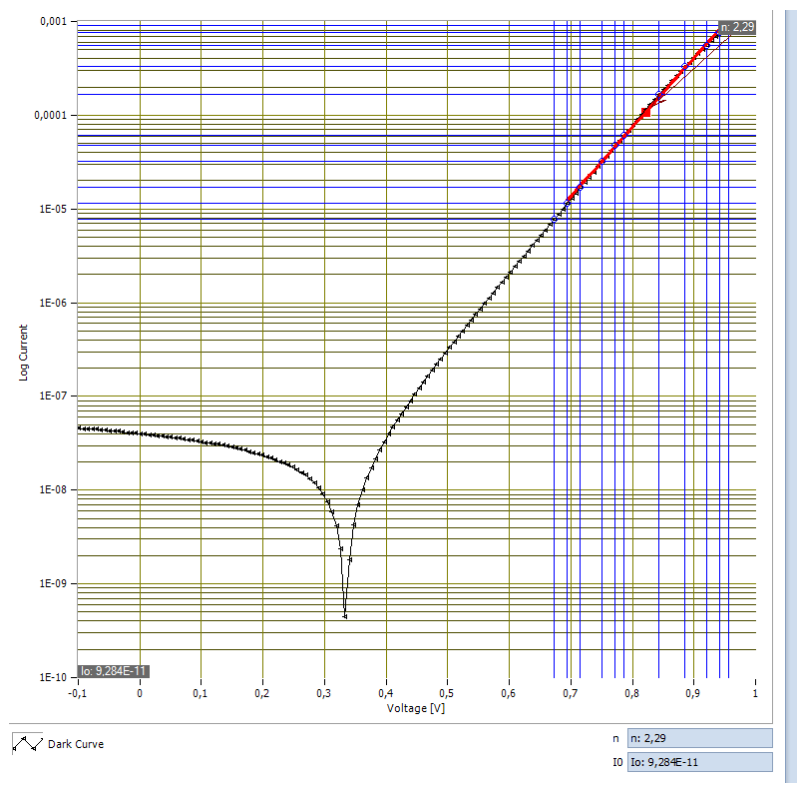

Figura 95: Curva I $\times$ V de uma CS no escuro, mostrando (em baixo à direita) os valores do fator de idealidade (n) e da corrente reversa $\left(I_{0}\right)$. 


\section{Resultados}

Como se trata do primeiro trabalho do laboratório na área de células fotovoltaicas, nossa primeira preocupação foi desenvolver todas as etapas básicas de processamento e de teste de maneira sistemática e reprodutível para construir uma célula de referência de GaAs com uma eficiência razoável. Depois disso, pudemos introduzir pontos quânticos nas amostras e verificar a influência deles em relação a uma célula de referência de GaAs. Uma vez que os problemas relacionados com a fotolitografia negativa e com o uso de máscaras adequadas para células solares foram superados, o primeiro grande desafio foi desenvolver contatos elétricos de boa qualidade, ou seja, que não prejudicassem o desempenho dos dispositivos.

A liga utilizada para a fabricação dos contatos sobre o GaAs tipo $\mathrm{N}$ já era bastante utilizada nas pesquisas do grupo relacionadas com o desenvolvimento de fotodetectores de radiação infravermelha. Como esses dispositivos são do tipo monopolar ${ }^{36}$, a mesma liga podia ser usada para os 2 contatos. Essa liga, formada pela deposição de filmes de $\mathrm{Ni} / \mathrm{Ge} / \mathrm{Au}$, com espessuras de $25 / 55 / 150 \mathrm{~nm}$, e recozida rapidamente a $520{ }^{\circ} \mathrm{C}$ por $30 \mathrm{~s}$ foi usada para os dois contatos (tipo $\mathrm{N}$ e $\mathrm{P}$ ) das nossas primeiras células solares (com a máscara usada para os fotodetectores), mas rapidamente percebemos que o contato tipo $\mathrm{P}$ precisava de uma liga específica diferente daquela usada para o contato tipo $\mathrm{N}$, pois a liga $\mathrm{Ni} / \mathrm{Ge} / \mathrm{Au}$ propiciava contatos com comportamento altamente não linear, mesmo após o recozimento térmico. Por essa razão, foi muito importante adquirirmos máscaras diferentes para os dois tipos de contato, que foram produzidas através da parceria com o LNnano, a partir dos desenhos realizados pelo grupo da Profa. Patrícia Lustoza na PUC-Rio. Também ficou claro que deveríamos analisar mais detalhadamente a formação desses contatos, o que nos levou a usar a técnica TLM. Essas medidas indicaram (Figura 96) que a resistividade de contato da nossa liga de Ni/Ge/Au em camadas do tipo $\mathrm{N}$ era da ordem de $10^{-5} \Omega \mathrm{cm}^{2}$, levando a resistências de contato da ordem de $1 \Omega$ para os contatos quadrados de $100 \mu \mathrm{m}$ de lado utilizados em nossos testes (figura 82).

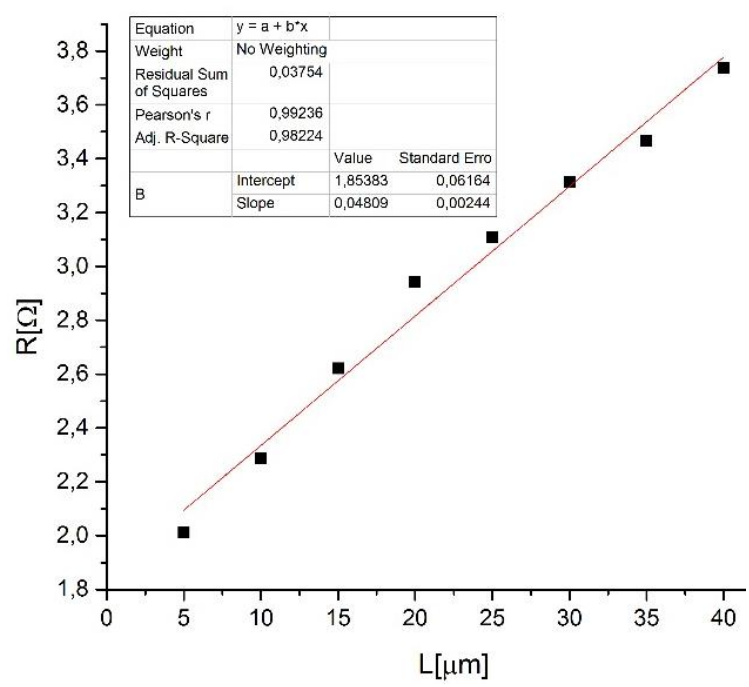

Tabela 2: Valores calculados a partir do gráfico mostrado na Figura 96.

\begin{tabular}{|l|l|}
\hline $\mathrm{W}[\mu m]$ & 100 \\
\hline $\mathrm{R}_{\mathrm{T}}[\Omega]$ & 1,854 \\
\hline $\mathrm{R}_{\mathrm{Sh}} / \mathrm{W}[\Omega / \mu m]$ & 0,048 \\
\hline $\mathrm{R}_{\mathrm{C}}[\Omega]$ & 0,927 \\
\hline $\mathrm{R}_{\mathrm{t}}[\Omega \cdot \mathrm{mm}]$ & 0,093 \\
\hline $\mathrm{R}_{\mathrm{Sh}}[\Omega]$ & 4,809 \\
\hline $\mathrm{L}_{\mathrm{T}}[\mu \mathrm{m}]$ & 19,275 \\
\hline$\rho_{C}\left[\Omega \cdot \mathrm{cm}^{2}\right]$ & $1,787 \mathrm{E}-05$ \\
\hline
\end{tabular}

Figura 96: Medidas de TLM para o contato tipo $N$ formado pela liga $\mathrm{Ni} / \mathrm{Ge} / \mathrm{Au}$.

\footnotetext{
${ }^{36}$ Formados pela junção NIN e, por tanto, possuem apenas um tipo de dopante.
} 
No que diz respeito aos contatos para camadas de GaAs do tipo P, procuramos na literatura [107] [108] [109] as ligas mais usadas e decidimos usar uma liga de Ti/Pt/Au cujos elementos estavam disponíveis em nosso sistema de deposição por feixe de elétrons. Após alguns testes, adotamos as espessuras de 20/100/200 nm que levaram a contatos ôhmicos, mesmo sem recozimento térmico, e aos resultados de TLM da Figura 97. Os testes mostraram que, geralmente, a resistência de contato para os contatos tipo $\mathrm{P}$ é maior que para os contatos tipo $\mathrm{N}$, mesmo considerando o uso das ligas apropriadas, sendo geralmente da ordem de $40 \Omega$, levando a uma resistividade de contato da ordem de $10^{-4} \Omega \mathrm{cm}^{2}$. Apesar desses valores serem maiores que aqueles obtidos geralmente na literatura (indicando que há necessidade de uma melhor otimização da nossa parte), os resultados obtidos com o simulador solar parecem demonstrar que isso não foi um problema nos dispositivos.

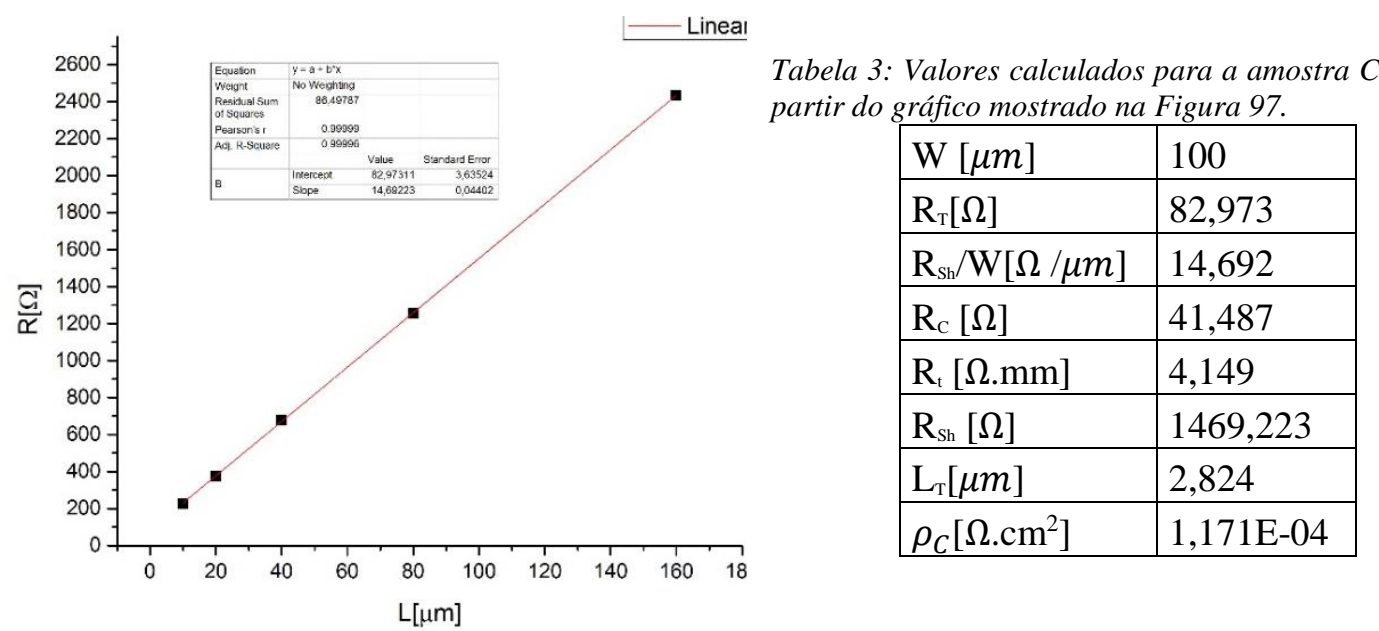

Figura 97: Medidas de TLM para o contato tipo P, sobre a amostra CS-FSF.

Na Tabela 4 são resumidos os principais parâmetros obtidos para os dois tipos de contato em algumas amostras e em algumas das células solares desse trabalho. Como, nas máscaras usadas, o padrão de TLM só possibilitava a análise do contato $\mathrm{P}$ superior, fizemos alguns testes para o contato $\mathrm{N}$ em uma amostra de GaAs contendo um fino filme de GaAs:Si (de $1 \mu \mathrm{m}$ de espessura) e no contato superior de um fotodetector (contendo também uma camada de GaAs:Si de $1 \mu \mathrm{m}$ de espessura).

Tabela 4: Tabela resumindo as informações dos gráficos 37 a 41. As medidas de TLM para o contato tipo $N$, com a utilização da liga $\mathrm{Ni} / \mathrm{Ge} / \mathrm{Au}$ com espessura de $25 / 55 / 150 \mathrm{~nm}$, respectivamente, submetida ao RTA de $520{ }^{\circ} \mathrm{C}$, por $30 \mathrm{~s}$. TLM para o contato tipo P, com a utilização de Pt/Ti/Au com espessura de 20, 100 e $200 \mathrm{~nm}$ respectivamente.

\begin{tabular}{lllllllll} 
Amostra & $\begin{array}{l}\text { Sobre } \\
\text { GaAs tipo }\end{array}$ & $\mathrm{W}[\mu \mathrm{m}]$ & $\mathrm{R}_{\mathrm{SH}} / \mathrm{W}[\Omega / \mu \mathrm{m}]$ & $\mathrm{R}_{\mathrm{C}}[\Omega]$ & $\mathrm{R}_{\mathrm{t}}[\Omega . \mathrm{mm}]$ & $\mathrm{R}_{\mathrm{SH}}[\mathrm{ohm}]$ & $\mathrm{L}_{\mathrm{TLM}}[\mu \mathrm{m}]$ & $\rho_{\mathrm{c}}\left[\Omega . \mathrm{cm}^{2}\right]$ \\
\hline GaAs:Si & $\mathrm{N}$ & 100 & 0,048 & 0,927 & 0,093 & 4,809 & 19,275 & $1,787 \mathrm{E}-05$ \\
\hline $\mathrm{KP} 90^{37}$ & $\mathrm{~N}$ & 100 & 0,032 & 0,619 & 0,062 & 3,209 & 19,295 & $1,195 \mathrm{E}-05$ \\
\hline CS-FSF & $\mathrm{P}$ & 100 & 14,692 & 41,487 & 4,149 & 1469,223 & 2,824 & $1,171 \mathrm{E}-04$ \\
\hline CS-QDSK & $\mathrm{P}$ & 100 & 8,034 & 38,108 & 3,811 & 803,394 & 4,743 & $1,808 \mathrm{E}-04$ \\
\hline CS-GaAs & $\mathrm{P}$ & 150 & 0,080 & 2,500 & 0,375 & 11,997 & 31,260 & $1,172 \mathrm{E}-04$ \\
\hline
\end{tabular}

\footnotetext{
${ }^{37}$ KP490 é uma amostra para fotodetector. Nessa amostra as medidas foram realizadas com um padrão TLM localizado na região do contato inferior.
} 
Durante o processo de otimização dos contatos tipo P e N por medidas de TLM foram realizadas algumas medidas com o simulador solar em células solares contendo contatos feitos com as ligas que estávamos testando e com os vários tipos de máscaras que tínhamos à nossa disposição. Quando começamos a obter resultados de boa qualidade e reprodutíveis, paramos o estudo dos contatos e iniciamos o processamento de todas as células solares com as ligas $\mathrm{Ni} / \mathrm{Ge} / \mathrm{Au}$ e Ti/Pt/Au mencionadas acima. Nossos primeiros testes resultaram em CSs com curvas anormais e eficiências inferiores a 2\% (Figura 98), devido a sérios problemas de contato, enquanto que com os contatos (e máscaras) adequados obtivemos uma curva $\mathrm{I} \times \mathrm{V}$ normal e eficiências superiores a $10 \%$ (Figura 99).
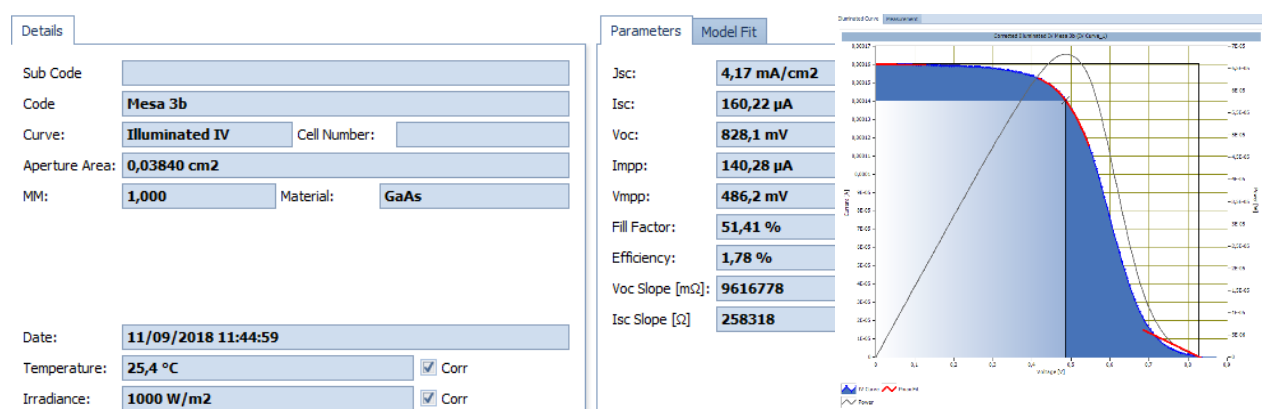

Figura 98: Curva I $\times$ V obtida com o simulador solar da CS de GaAs fabricada com a máscara dos fotodetectores e usando a liga $\mathrm{Ni} / \mathrm{Ge} / \mathrm{Au}$ para os dois tipos de contato. Podemos ver que a resistência em série (provavelmente dos contatos) é muito alta, e a eficiência muito baixa $(1,78 \%)$.
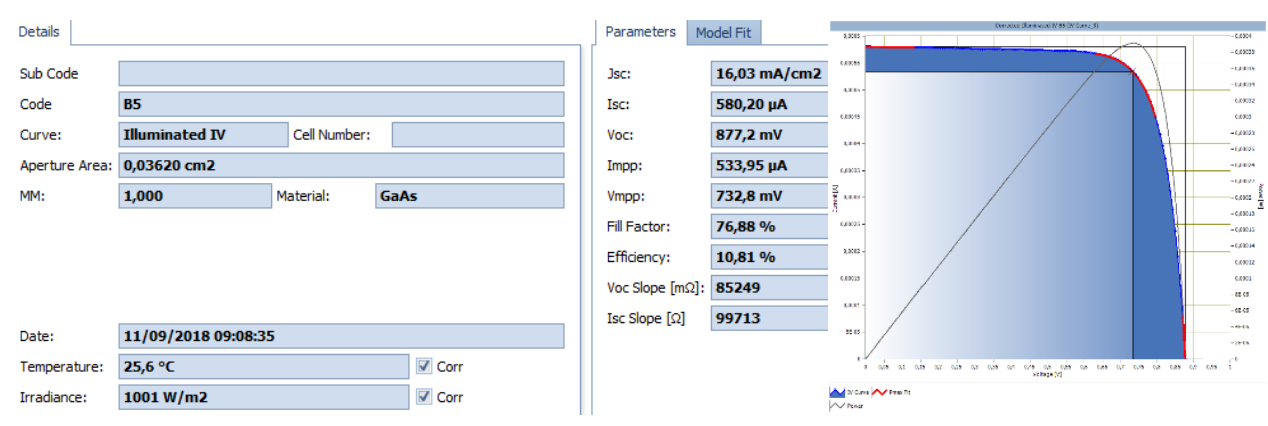

Figura 99: Curva IV obtida com o simulador solar para a CS-GaAs, fabricada com as novas máscaras da PUC-Rio, usando a liga Ni/Ge/Au para o contato $N$ e a liga Ti/Pt/Au para o contato P. A resistência em série ficou muito menor e a curva em geral possui a forma habitual, levando a uma eficiência de 10,81\%.

As amostras crescidas em nosso sistema MBE possuem o tamanho de $1 / 4$ de um substrato de 3 polegadas, o que seria suficiente para processar de uma única vez várias células de cada tamanho com um diferente número de "fingers". Todavia, por medida de segurança ${ }^{38}$, processamos apenas a metade de cada amostra, o que nos obrigou a escolher um número reduzido de células. Mesmo assim, para cada amostra, tentamos escolher sempre as mesmas células das máscaras para que o desempenho delas pudesse ser comparado. Para podermos avaliar a influência do tamanho das células (temos 3 tamanhos diferentes de aproximadamente $2 \times 2 \mathrm{~mm}^{2}$,

\footnotetext{
${ }^{38}$ Caso alguma etapa do processo de fabricação das células desse errado, perderíamos toda a amostra. Por isso, reservamos parte das amostras para evitar que isso acontecesse.
} 
$3 \times 3 \mathrm{~mm}^{2}$ e $5 \times 5 \mathrm{~mm}^{2}$ ), assim como, para um determinado tamanho, a influência do número de "fingers", montamos gráficos contendo as 2 informações. Os gráficos têm que ser lidos da seguinte maneira: a cada valor da área iluminada ${ }^{39}$ de uma célula (lido na escala vertical da esquerda) corresponde um valor de eficiência (quadrado preto cheio) e, na mesma abscissa, temos um quadrado vazio (branco) relacionado com o número de "fingers" dessa mesma célula (escala vertical da direita), sendo que células do mesmo tamanho podem ter um número diferente de "fingers" em função da sua localização na máscara. Além disso, para cada amostra, apresentamos uma tabela com os valores máximos obtidos por área e por número de "fingers". As figuras e tabelas das 3 primeiras células possuindo uma região ativa só de GaAs são apresentadas a seguir.

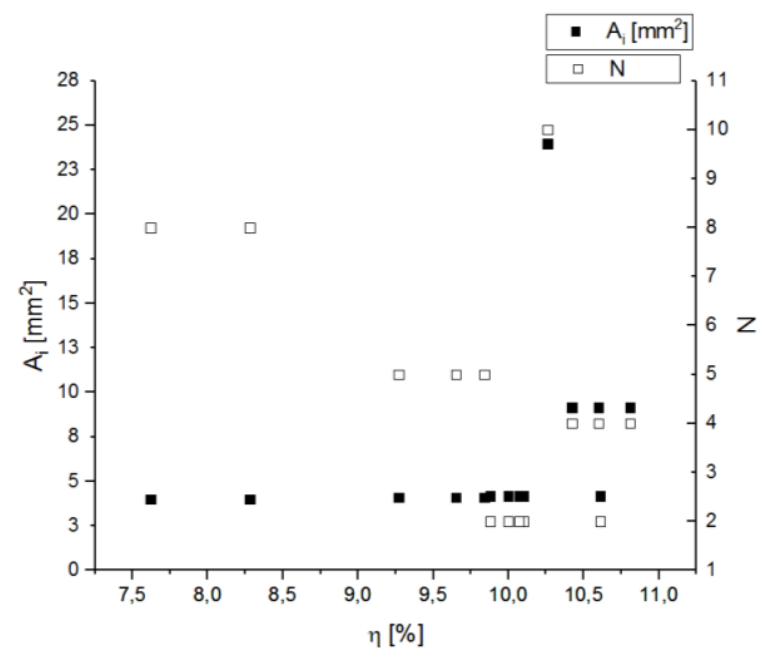

Figura 100: Relação entre a eficiência da amostra CS-GaAs (plotada no eixo horizontal) e a área total iluminada $A_{i}$ (plotada no eixo esquerdo), assim como o número de "fingers" $N$ (plotado no eixo direito). São plotados apenas os valores de máxima eficiência para cada tipo de mesa.

Tabela 5: Dados da amostra de referência CS-GaAs obtidos com auxílio do simulador solar.

\begin{tabular}{crrrcc}
\hline Mesa & \multicolumn{1}{c}{$\eta$} & $\mathrm{A}_{\mathrm{i}}\left[\mathrm{mm}^{2}\right]$ & $\mathrm{N}$ & $\mathrm{J}_{\mathrm{sc}}\left[\mathrm{mA} / \mathrm{cm}^{2}\right]$ & $\mathrm{V}_{\text {oc }}[\mathrm{mV}]$ \\
\hline B06 & $8,28 \%$ & 3,9935 & 8 & 16,17 & 829,2 \\
\hline B05 & $9,84 \%$ & 4,0858 & 5 & 16,03 & 877,2 \\
\hline B14 & $10,26 \%$ & 23,9691 & 10 & 15,23 & 843,0 \\
\hline B04 & $10,61 \%$ & 4,1848 & 2 & 15,40 & 912,0 \\
\hline B10 & $10,81 \%$ & 9,1610 & 4 & 15,33 & 890,7 \\
\hline
\end{tabular}

\footnotetext{
${ }^{39} \mathrm{~A}$ área iluminada é a área ativa da amostra, isto é, a área total da célula menos a área coberta pelos "fingers" e "busbar".
} 


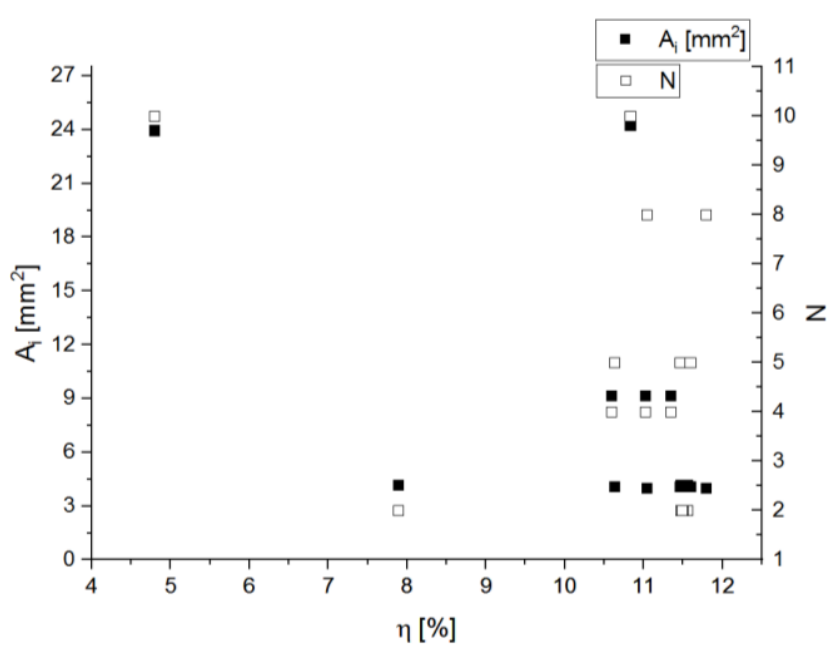

Figura 101: Relação entre a eficiência da amostra CS-FSF (plotada no eixo horizontal) e a área total iluminada $A_{i}$ (plotada no eixo esquerdo), assim como o número de "fingers" $N$ (plotado no eixo direito). São plotados apenas os valores de máxima eficiência para cada tipo de mesa.

Tabela 6: Dados da amostra CS-FSF obtidos com auxílio do simulador solar.

\begin{tabular}{ccrrcc}
\hline Mesa & $\eta$ & $\mathrm{A}_{\mathrm{i}}\left[\mathrm{mm}^{2}\right]$ & $\mathrm{N}$ & $\mathrm{J}_{\mathrm{sc}}\left[\mathrm{mA} / \mathrm{cm}^{2}\right]$ & $\mathrm{V}_{\text {oc }}[\mathrm{mV}]$ \\
\hline B02 & $10,83 \%$ & 24,2419 & 10 & 15,70 & 925,5 \\
\hline B10 & $11,34 \%$ & 9,1610 & 4 & 15,99 & 927,9 \\
\hline B03 & $11,56 \%$ & 4,1848 & 2 & 16,62 & 908,4 \\
\hline B12 & $11,59 \%$ & 4,0858 & 5 & 16,67 & 889,8 \\
\hline B13 & $11,79 \%$ & 3,9935 & 8 & 16,75 & 899,6 \\
\hline
\end{tabular}

Na comparação da CS-FSF com a referência CS-GaAs, verificamos que o fato de colocar uma camada de AlGaAs na parte superior da estrutura da CS-FSF para impedir a recombinação dos portadores na superfície fez com que a eficiência da CS-FSF fosse significativamente melhorada (Figura 102) em relação à da CS-GaAs, o que ocorreu devido a um aumento tanto de $\mathrm{I}_{\mathrm{SC}}$ quanto de $\mathrm{V}_{\mathrm{OC}}$. A janela passiva os estados da superfície do emissor que podem agir como armadilhas para os portadores de carga minoritários e, dessa forma, ajuda a diminuir a taxa de recombinação nessa superfície [21] [55]. Isso fez com que a eficiência do dispositivo aumentasse. Como o próprio nome dessa fina camada de $\mathrm{AlGaAs}$ sugere (janela), ela também possui a função de deixar passar a radiação solar com a menor absorção possível. Por essa razão, o conteúdo de $\mathrm{Al}$ costuma ser muito alto (até 90\%) para que o gap da liga seja muito mais alto que o do GaAs e que a maior parte da radiação possa ser absorvida nas camadas de GaAs posteriores que formam a região ativa do dispositivo. A nossa escolha por um conteúdo de apenas $28 \%$ foi determinada principalmente pelo receio que o problema (ou suspeita) de contaminação da nossa célula de $\mathrm{Al}$ pudesse prejudicar o dispositivo inteiro se usássemos uma alta concentração de $\mathrm{Al}$ nessa camada. A partir dos resultados apresentados acima, fica claro que eficiências mais altas poderão certamente ser obtidas pelo simples aumento do teor de Al na camada. 


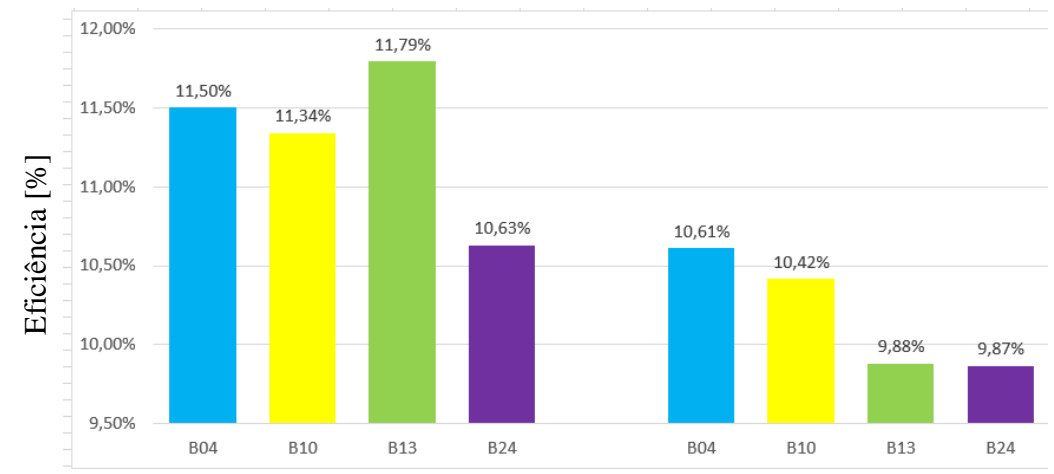

Figura 102: Comparação entre as eficiências das mesas da CS-FSF à esquerda e da CS-GaAs à direita.

De posse dos dados da amostra CS-FSF, construímos a CS-F\&BSF que possui uma BSF formada por uma camada de AlGaAs em vez da camada espessa de GaAs dopada com Si $\left(5 \times 10^{18}\right.$ $\mathrm{cm}^{-3}$ ), para que pudéssemos verificar se a eficiência iria melhorar em relação à da CS-FSF.

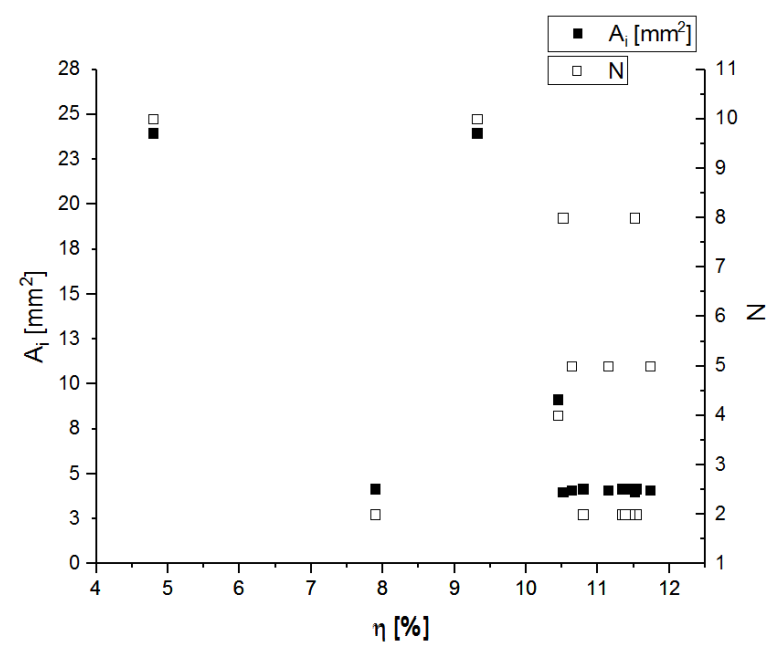

Figura 103: Relação entre a eficiência da amostra CS-F\&BSF (plotada no eixo horizontal) e a área total iluminada $A_{i}$ (plotada no eixo esquerdo), assim como o número de "fingers" $N$ (plotado no eixo direito). São plotados apenas os valores de máxima eficiência para cada tipo de mesa.

Tabela 7: Dados da amostra CS-F\&BSF obtidos com auxílio do simulador solar.

\begin{tabular}{crrrcc}
\hline Mesa & \multicolumn{1}{c}{$\eta$} & $\mathrm{A}_{\mathrm{i}}\left[\mathrm{mm}^{2}\right]$ & $\mathrm{N}$ & $\mathrm{J}_{\mathrm{sc}}\left[\mathrm{mA} / \mathrm{cm}^{2}\right]$ & $\mathrm{V}_{\text {oc }}[\mathrm{mV}]$ \\
\hline B14 & $9,31 \%$ & 23,9691 & 10 & 15,64 & 950,2 \\
\hline B11 & $10,44 \%$ & 9,1610 & 4 & 16,21 & 917,3 \\
\hline B06 & $11,51 \%$ & 3,9935 & 8 & 16,91 & 898,5 \\
\hline B03 & $11,53 \%$ & 4,1848 & 2 & 16,69 & 910,0 \\
\hline B24 & $11,73 \%$ & 4,0858 & 5 & 16,81 & 905,9 \\
\hline
\end{tabular}

Na comparação da CS-F\&BSF com a CS-FSF, parece que os resultados da CS-F\&BSF ficaram geralmente parecidos (dentro das flutuações do processamento) ou eventualmente levemente piores, sugerindo que o acréscimo da camada de AlGaAs na parte inferior da estrutura possa ter piorado levemente a situação em relação a uma camada espessa de GaAs mais dopada, 
como podemos ver na figura 104. Pode ser que esse resultado, um pouco inesperado, seja devido aos problemas que temos ultimamente com nossa célula de Al que parece estar apresentando um problema de contaminação que estamos investigando. A camada de AlGaAs parece ter piorado levemente o desempenho da CS-F\&BSF pois já tinha um BSF de GaAs na CS-FSF, mas, apesar disso, esta mesma camada de AlGaAs conseguiu melhorar a qualidade da CS-FSF em relação à CS-GaAs pois, nesta última, não tinha outra camada fazendo esse papel (de janela). Para tirar essa dúvida, o ideal teria sido comparar uma célula solar com BSF de AlGaAs com outra célula sem nenhum tipo de BSF para ver se havia diferença na eficiência.

Já que esta amostra é a última do conjunto com uma região ativa contendo apenas GaAs, vale a pena fazer aqui mais um comentário. Foi mencionado no início do trabalho que as razões pelo uso das estruturas apresentadas nesse trabalho eram minimizar o tempo de crescimento das amostras e manter uma certa semelhança com estruturas testadas no grupo da PUC-Rio para poder comparar os resultados e avaliar as técnicas envolvidas no processamento e caracterização dos dispositivos. Isso fez com que a região intrínseca de GaAs fosse limitada a $1 \mu \mathrm{m}$ de espessura. Pode-se reparar que as células desse tipo apresentando os melhores resultados na literatura são fabricadas com uma região intrínseca variando entre 3 e $4 \mu \mathrm{m}$ de espessura, o que, combinado com uma janela possuindo um conteúdo muito maior de $\mathrm{Al}$, deveria possibilitar que obtenhamos no futuro eficiências maiores que aquelas alcançadas aqui.

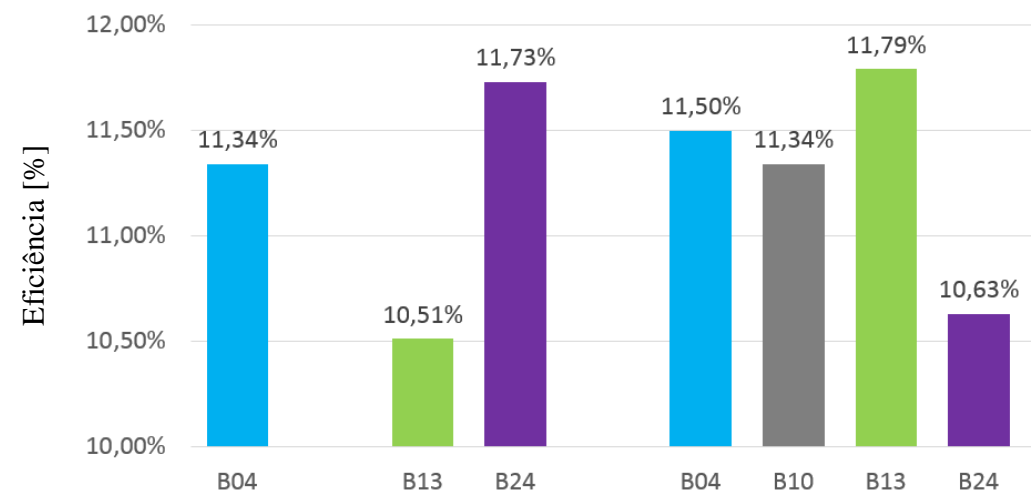

Figura 104: Comparação entre as eficiências das mesas da CS-F\&BSF à esquerda e da CS-FSF à direita.

Como, das 3 amostras com região ativa de GaAs, a CS-FSF foi aquela que obteve o melhor desempenho, decidimos construir uma célula solar parecida mas contendo pontos quânticos de Stranski-Krastanov no meio da região ativa (CS-QDSK) para tentar aumentar a eficiência do dispositivo com uma absorção suplementar pelos QDs numa faixa de energia abaixo do gap do GaAs. A figura com o desempenho dessas células e a tabela com o resumo dos dados estão a seguir. 


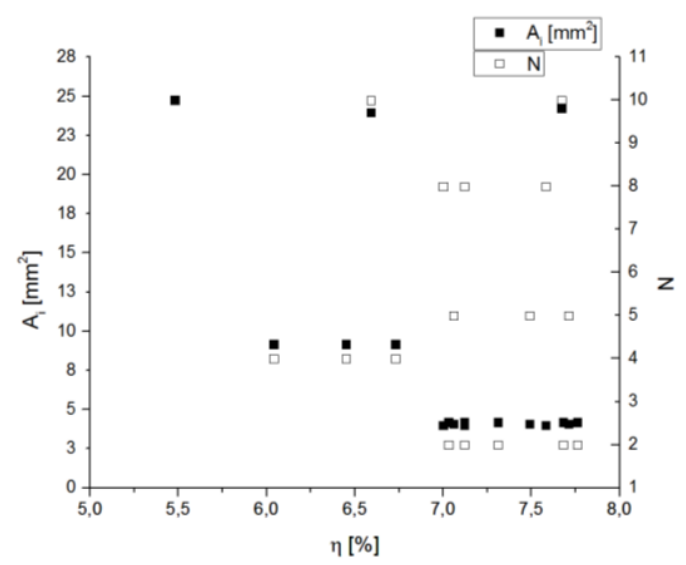

Figura 105: Relação entre a eficiência da amostra CS-QDSKS BSF (plotada no eixo horizontal) e a área total iluminada $A_{i}$ (plotada no eixo esquerdo), assim como o número de "fingers" $N$ (plotado no eixo direito). São plotados apenas os valores de máxima eficiência para cada tipo de mesa.

Tabela 8: Dados da amostra CS-QDSK obtidos com auxílio do simulador solar.

\begin{tabular}{rrrrcc}
\hline Mesa & $\eta$ & $\mathrm{A}_{\mathrm{i}}\left[\mathrm{mm}^{2}\right]$ & $\mathrm{N}$ & $\mathrm{J}_{\mathrm{sc}}\left[\mathrm{mA} / \mathrm{cm}^{2}\right]$ & $\mathrm{V}_{\text {oc }}[\mathrm{mV}]$ \\
\hline B28 & $5,48 \%$ & 24,7873 & 10 & 14,31 & 635,3 \\
\hline B14 & $6,59 \%$ & 23,9691 & 10 & 14,59 & 708,5 \\
\hline B09 & $6,73 \%$ & 9,1610 & 4 & 14,46 & 689,9 \\
\hline B06 & $7,58 \%$ & 3,9935 & 8 & 15,56 & 707,8 \\
\hline B05 & $7,71 \%$ & 4,0858 & 5 & 15,36 & 718,1 \\
\hline B04 & $7,76 \%$ & 4,1848 & 2 & 15,42 & 723,0 \\
\hline
\end{tabular}

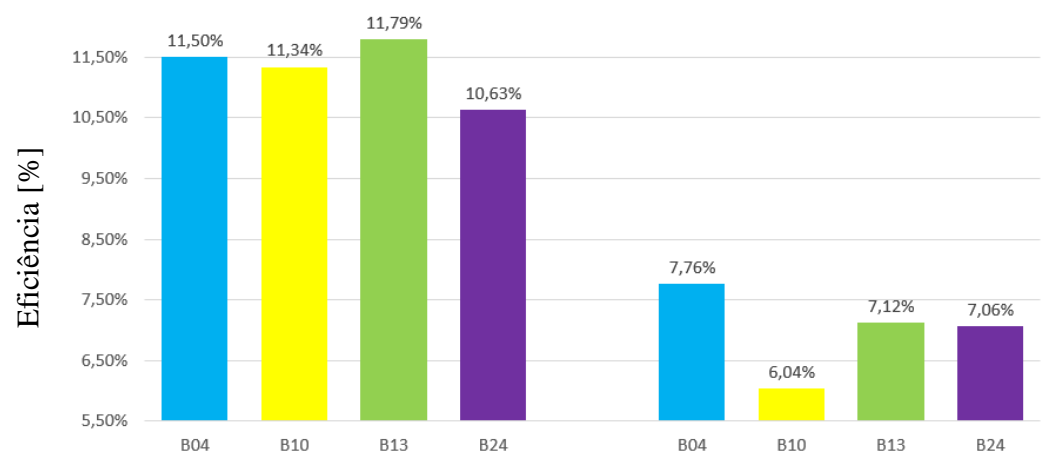

Figura 106: Comparação entre as eficiências das mesas da CS-FSF à esquerda e da CS-QDSK à direita.

A figura 106 mostra claramente que a introdução dos pontos quânticos na estrutura da CS-QDSK reduziu a eficiência das células em cerca de 40\%, sendo que, segundo a Tabela 8, o maior responsável é o valor de $\mathrm{V}_{\mathrm{OC}}$ que recuou consideravelmente em relação à CS-FSF (de cerca de $900 \mathrm{mV}$ para valores abaixo de $700 \mathrm{mV}$ ), o que é geralmente relacionado com um aumento dos defeitos na estrutura. 
A primeira causa na qual poderíamos pensar para justificar esta diminuição considerável da eficiência é uma má qualidade da amostra ou dos QDs em razão da grande diferença de parâmetro de rede entre o GaAs e o InAs (7\%). Todavia, nosso grupo possui uma grande experiência na área de crescimento de QDs de InAs que, nesse caso, foram crescidos em condições usuais que costumam produzir nanoestruturas de boa qualidade como aquelas já mostradas na figura 37. Todavia, é um fato que o crescimento de QDs é certamente acompanhado por uma certa densidade de defeitos estruturais, mesmo nas melhores amostras, principalmente no interior de pontos quânticos relaxados e na interface entre os materiais InAs e GaAs. Alguns trabalhos já mostraram que um recozimento das amostras em mais alta temperatura consegue diminuir o número desses defeitos e melhorar a qualidade dos dispositivos [110]

Uma segunda razão que poderia ser elencada para explicar a redução de eficiência é um problema na dopagem dos QDs. Todavia, apesar da dopagem ser importante para obter a maior eficiência possível, acreditamos que ela não seja responsável por uma diminuição tão grande da eficiência (principalmente pela redução de $\mathrm{V}_{\mathrm{OC}}$ ). O simples fato de inserir QDs dopados na estrutura já gera em si uma absorção suplementar. O ideal seria dopar a amostra de tal maneira que o nível fundamental dos QDs (na banda de condução) seja totalmente populado, possibilitando assim a absorção de radiação pela transição dos portadores desse nível para a banda de condução do GaAs. Nesse trabalho, usamos uma dopagem equivalente a 4 átomos de Si para cada QD da amostra, valor de dopagem usualmente empregado em nossos fotodetectores de radiação infravermelha (mas não necessariamente otimizado). Isso deveria popular completamente o nível fundamental dos QDs com 2 elétrons, sendo que os outros são presos em armadilhas ou eletricamente inativos devido à incorporação do Si em sítios diferentes do Ga. Mas é um fato que alguns trabalhos adotam dopagens ainda maiores.

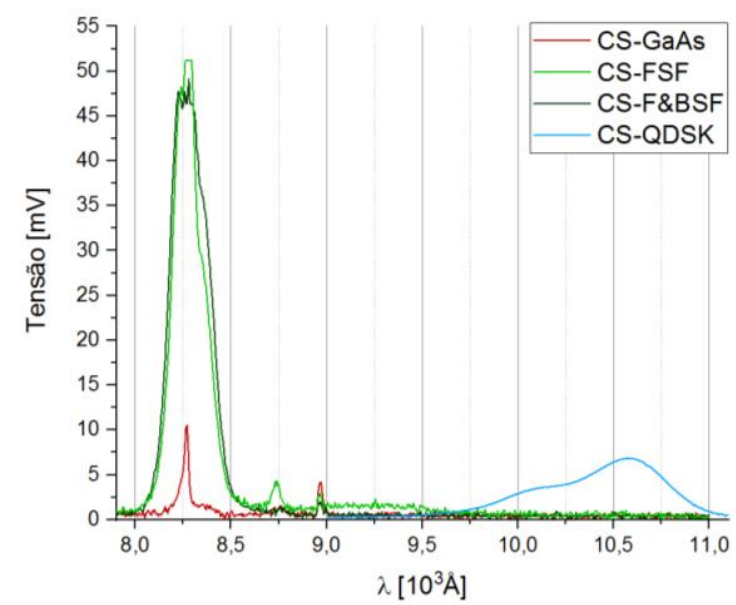

Figura 107: Espectro de PL da estrutura das 4 células solares a $77 \mathrm{~K}$..

Para confirmar a qualidade óptica dos QDs da CS-QDSK, realizamos medidas de PL nas 4 amostras (figura 107). Podemos constatar que todas as amostras apresentam um pico em torno de $825 \mathrm{~nm}$, que é o valor do gap do GaAs a $77 \mathrm{~K}$. Esse pico é mais intenso nas amostras CS-FSF e CS-F\&BSF que possuem uma camada de AlGaAs no topo da estrutura que impede a captura dos portadores fotogerados pela superfície e portanto aumenta o sinal de recombinação radiativa no GaAs. Podemos também observar que a amostra CS-QDSK possui uma emissão extra entre 
975 e $1100 \mathrm{~nm}$ que está relacionada com a recombinação radiativa de elétrons a partir do nível fundamental (pico em $1060 \mathrm{~nm}$ ) e do primeiro nível excitado (pico em $1010 \mathrm{~nm}$ ) dos QDs. Este sinal ainda é bem visível, apesar dos QDs estarem cobertos por uma camada de material de cerca de $0.5 \mu \mathrm{m}$ de espessura, o que indica uma boa qualidade da amostra.

Uma maneira mais direta de evidenciar o efeito da presença dos pontos quânticos em relação à possibilidade de se absorver parte da radiação possuindo uma energia menor que o valor do gap do GaAs consiste em fazer uma medida de absorção. Como o nosso arranjo experimental ainda está em fase de montagem e calibração, pudemos apenas fazer medidas simples (qualitativas) de absorção, e ainda não temos condições de fazer os cálculos completos para encontrar os valores de responsividade e eficiência quântica dos dispositivos que requerem o conhecimento de parâmetros geométricos e ópticos do sistema. Na, podemos ver que a curva de absorção da célula de GaAs puro (CS-FSF) obtida na temperatura ambiente possui um espectro cuja intensidade cai abruptamente a zero para comprimentos de onda superiores a $900 \mathrm{~nm}$, valor que coincide com o gap do GaAs. A medida realizada nas mesmas condições com a célula contendo QDs apresenta claramente um sinal elétrico na faixa de comprimentos de onda acima de $900 \mathrm{~nm}$, o que só pode ser explicado fisicamente pela absorção desta radiação pelos QDs, comprovando assim a efetividade deles. A descontinuidade do sinal perto de $1000 \mathrm{~nm}$ (presente nas duas medidas!) é um artefato do nosso sistema devido à troca da grade de difração do monocromador que ocorre automaticamente nesse valor para possibilitar uma medida de qualidade numa ampla faixa de comprimentos de onda. Parece prematuro discutir agora as outras diferenças entre as duas curvas, pois podem ser consequência da precariedade do nosso sistema atual de medida e provavelmente não estão associados a efeito físicos.

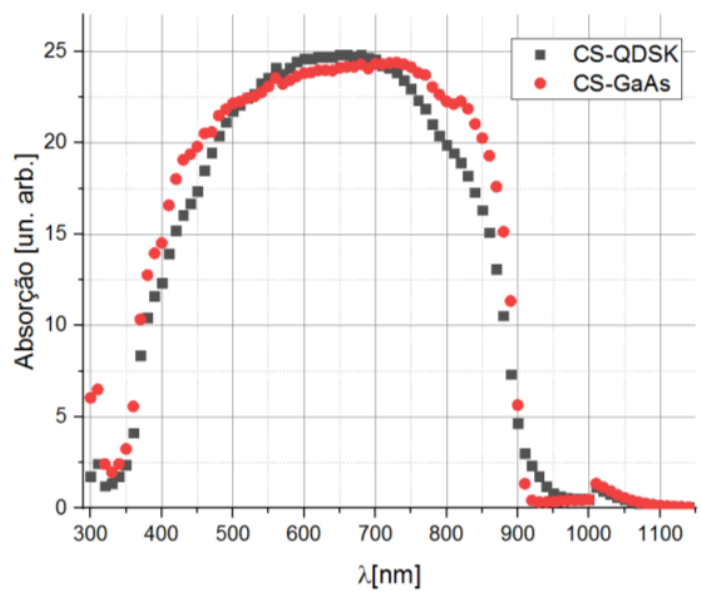

Figura 108: Curvas de absorção das amostras CS-QDSK e CS-FSF.

As curvas I-V produzidas pelo simulador no escuro e na presença da radiação solar providenciem vários parâmetros importantes que podem ser analisados e fornecer mais informações a respeito das diferenças entre essas duas células solares. O gráfico da figura 109 mostra que, do ponto de vista do fator de idealidade, as duas células se comportam de maneira parecida. Todavia, quando se considera a corrente reversa do diodo $\left(\mathrm{J}_{0}\right)$, percebe-se que os valores da célula com QDs são cerca de 2 ordens de grandeza maiores que na amostra de referência (figura 110). Isso pode estar relacionado com a elevação do número de defeitos estruturais gerados pela presença dos QDs que aumentam a recombinação de portadores e fazem com que a corrente reversa aumente significativamente. 


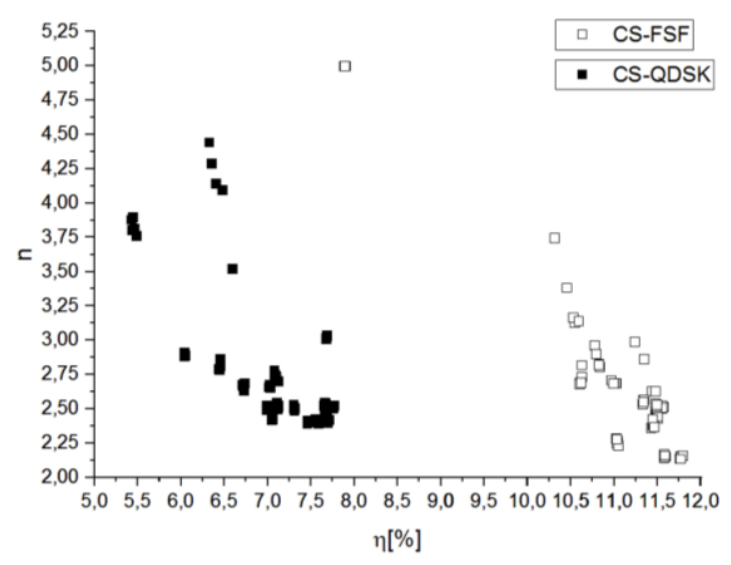

Figura 109: Fator de idealidade versus eficiência para as amostras CS-FSF e CS-QDSK.

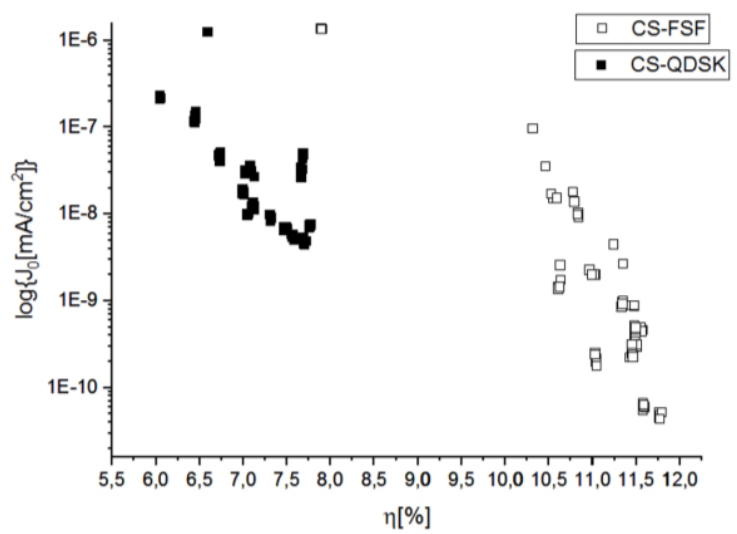

Figura 110: Corrente de escuro (Jo) versus a eficiência das amostras CS-FSF e CS-QDSK.

Portanto, acreditamos que a razão da redução da eficiência observada nas células contendo QDs esteja relacionada com a introdução de defeitos estruturais na amostra durante o crescimento dos QDs, principalmente pela presença de pontos quânticos relaxados que contêm linhas de deslocações para poder adaptar o parâmetro de rede do InAs ao do GaAs, e pela introdução de defeitos pontuais na interface entre os dois materiais. Todavia, o fator mais importante para esse baixo desempenho parece ser a posição das camadas de QDs que foram distribuídas homogeneamente na região ativa para diminuir a tensão mecânica. Teria sido muito melhor deixar uma camada espessa de GaAs na parte superior da região ativa e concentrar as camadas de QDs na parte inferior. Dessa maneira, a região de GaAs teria uma densidade reduzida de defeitos e poderia absorver a radiação nas mesmas condições que a célula de referência CSGaAs. Além disso, como as energias de transição relacionadas com os QDs são menores que a energia do gap do GaAs, é importante que os QDs estejam localizados no fundo da estrutura, para permitir que a radiação com energia maior que o gap possa ser absorvida na região superior de $\mathrm{GaAs}$, enquanto que a radiação com energia menor que o gap poderá atravessar todas essas camadas de material e ser absorvida diretamente na região dos QDs. Recentemente, o recorde de eficiência obtido com esse tipo de célula baseada em QDs de InAs foi de 21.7\% [111], proporcionando uma melhora (relativa) de 17,4\% em relação à célula de referência de GaAs (que tinha ainda um filme antirreflexivo na superfície). 
Após a análise dos dados dos diferentes tipos de células solares, decidimos realizar uma última modificação que consiste na remoção da camada fina de GaAs altamente dopado (para melhorar o contato tipo P) para que fosse verificada a influência desse procedimento na eficiência, já que essa camada, apesar de ser fina, poderia absorver parte da radiação incidente. A figura 111 mostra os resultados para a amostra CS-FSF que possuía a maior eficiência antes do procedimento (cerca de $11,5 \%$ ). Ficou claro que a remoção, por corrosão química controlada, da camada fina de contato melhorou a eficiência dos dispositivos de cerca de $2.5 \%$ (em valores absolutos), o que elevou a eficiência máxima obtida nesse trabalho acima de $14 \%$.

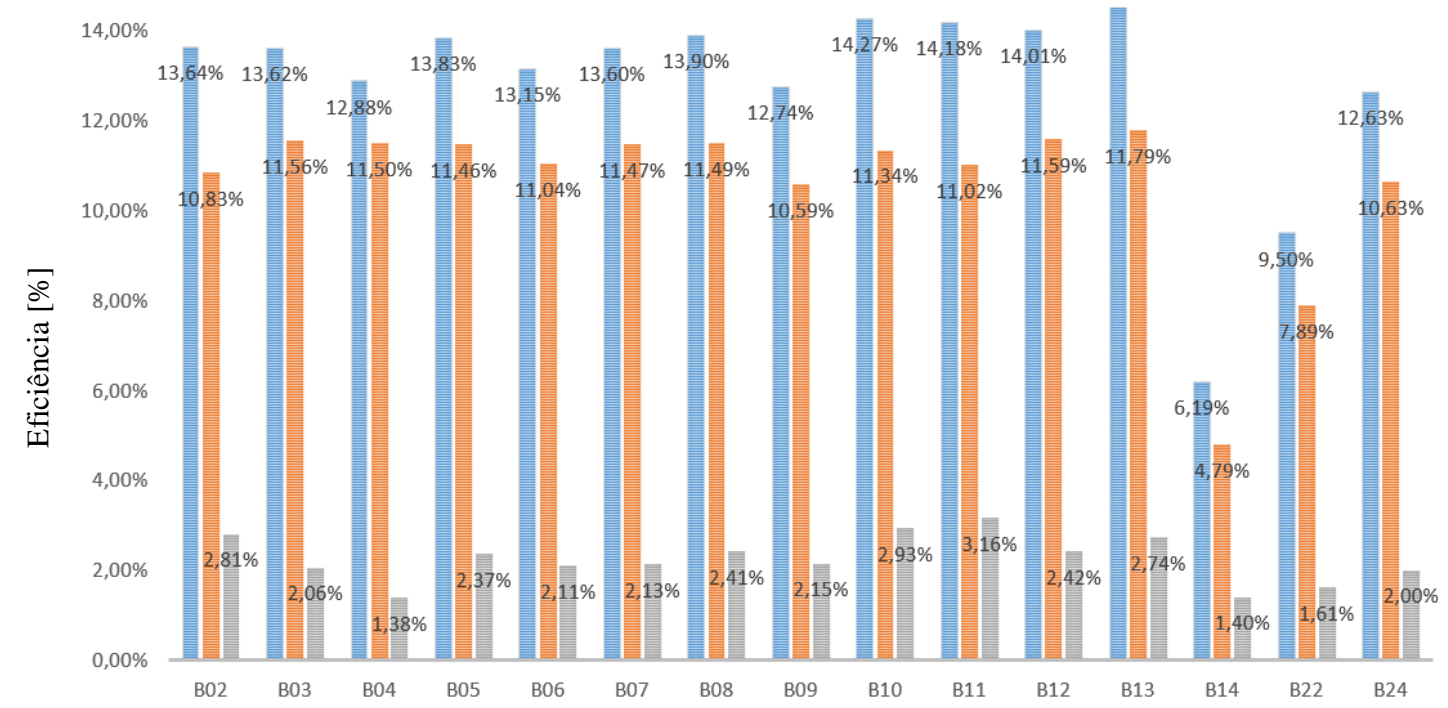

Figura 111: Efeito da remoção do fino cap layer altamente dopado nos valores de eficiência da amostra CS-FSF. As barras laranjas são os valores de eficiência das mesas antes da remoção do Cap Layer. As barras azuis são as eficiências obtidas após a remoção do cap layer. A barra cinza é o ganho de eficiência.

Uma síntese dos principais resultados obtidos neste trabalho após cada uma das modificações realizadas na primeira célula de GaAs pode ser encontrada nas figuras 112 e 113, assim como na tabela 9. As 3 máscaras usadas no processamento continham vários tamanhos de células ( $2 \mathrm{~mm}, 3 \mathrm{~mm}$ e $5 \mathrm{~mm}$ de lado) possuindo um número diferente de "fingers" (de 2 a 10) para eventualmente poder-se analisar a influência desses dois parâmetros sobre o desempenho final dos dispositivos. Todos os gráficos de eficiência em função desses dois parâmetros apresentados nesse trabalho indicaram que, de maneira geral, as células menores possuíam uma eficiência levemente mais alta que as outras, e que o número de "fingers" não era muito relevante. A figura 112 resume os dados dos 5 tipos de células desenvolvidas possuindo um tamanho de 2 mm mas com um número diferente de "fingers" (todas têm 2 "fingers" exceto a B05 e B06 que têm, respectivamente, 5 e 8 "fingers", como pode ser visto no apêndice). Podemos ver que não existe correlação entre os valores de eficiência e o número de "fingers", o que significa que as flutuações encontradas são provavelmente oriundas das variações inerentes ao processamento (defeitos, metalização, RTA). Essa informação é útil pois significa que, em vez de ter uma máscara com células de vários tamanhos que não oferecem um bom desempenho, poderíamos fabricar uma nova máscara com apenas células pequenas possuindo poucos "fingers", o que permitiria ter um maior número de dispositivos idênticos para testar e fazer avaliações estatísticas de melhor qualidade. 


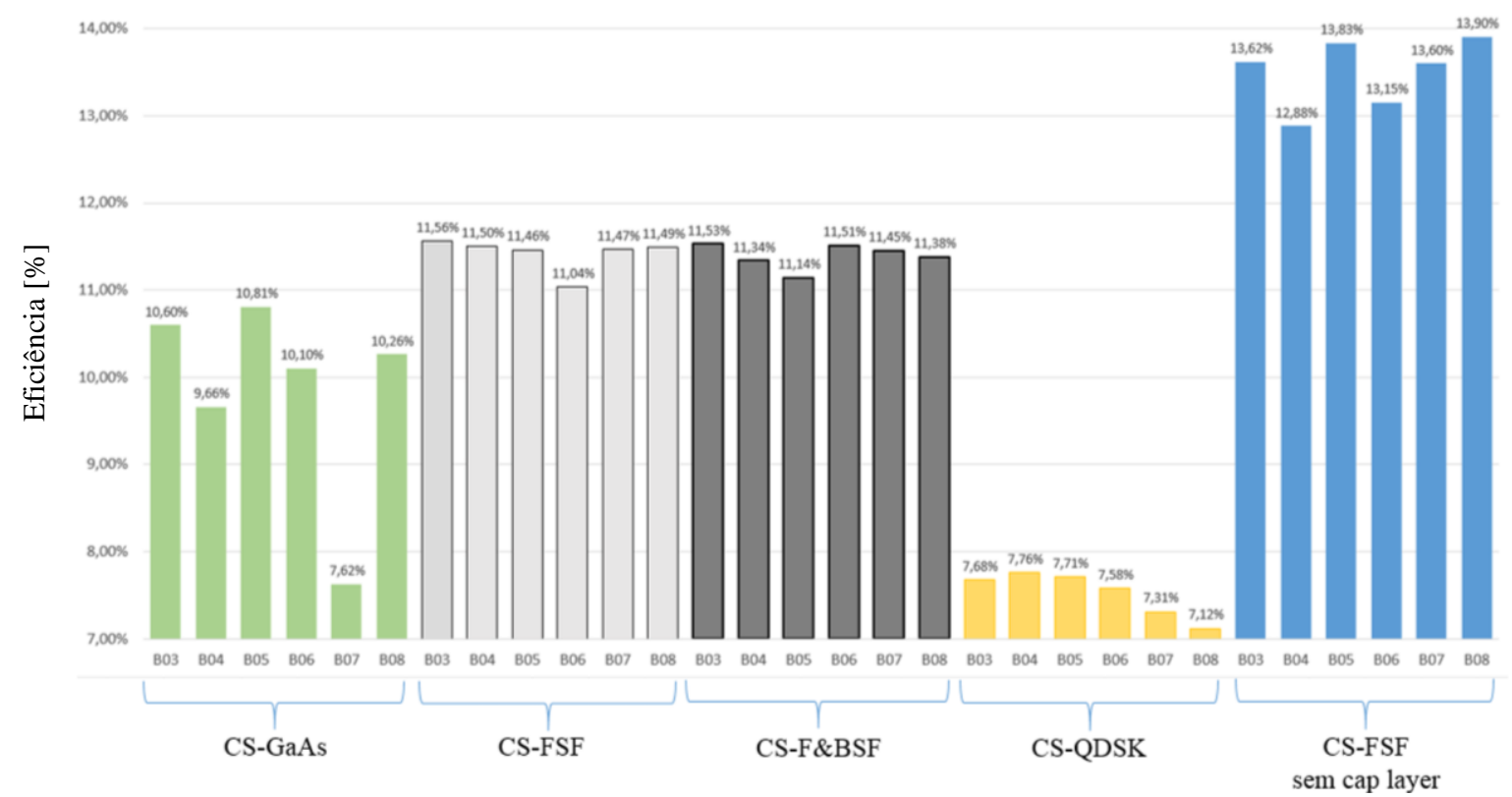

Figura 112: Comparação dos valores máximos de eficiência obtidos nas medições das mesas B03 a B08 (2 mm de lado) de cada amostra.

A figura 113 mostra a curva $J \times V$ da melhor célula de cada tipo da figura 112. Para efeito de comparação, inserimos também os dados da célula de GaAs comercial que veio junto com o simulador solar para calibrar a irradiância do sistema. Esta célula possui uma área óptica de cerca de $4 \mathrm{~mm}^{2}$, assim como uma camada antirreflexiva para diminuir a reflexão da radiação incidente devido à grande diferença de índice de refração entre o GaAs e o ar (3.5 e 1.0, respectivamente, no visível). A corrente total produzida por esta célula é muito maior que a das nossas células, que são de tamanho bem menor, mas como o gráfico foi feito com a densidade de corrente $\mathrm{J}$ (corrente total dividida pela área da célula), esses valores são mais parecidos. Incluímos também no gráfico uma célula que não foi discutida nessa trabalho, pois foi obtida e medida apenas alguns dias antes da defesa. Trata-se da CS-FSF da qual removemos o fino "cap layer" extremamente dopado e em cima da qual depositamos posteriormente uma camada de $\mathrm{Al}_{2} \mathrm{O}_{3}$ de $85 \mathrm{~nm}$ de espessura que atua como camada antirreflexiva. Ela faz parte do trabalho desenvolvido por um aluno de doutorado do nosso grupo (Thales Borrely dos Santos), mas achamos interessante incluir esse dado preliminar para verificar se o desempenho desse dispositivo estava se aproximando do desempenho da célula comercial. A tabela 9 complementa os dados da figura 113, fornecendo os valores de fator de preechimento ("fill factor") e da eficiência. Podemos fazer as seguintes observações: 

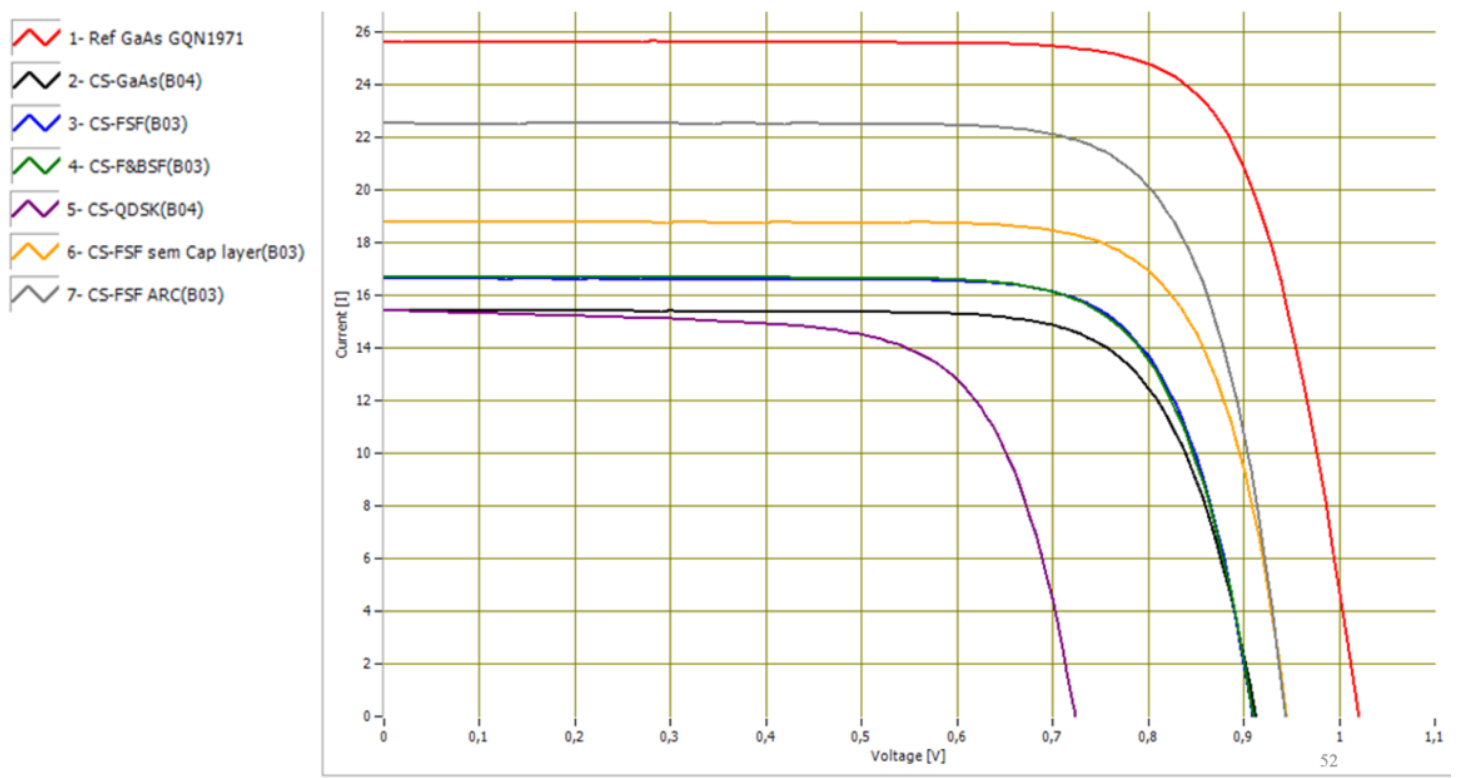

Figura 113: Curvas JxV de nossas CSs com a mesma área superficial (2 mm de lado) e o mesmo número de "fingers", (2), tendo portanto todas a mesma área iluminada. Acrescentamos, para fim de comparação, a curva de uma célula solar comercial de GaAs usada para a calibração do simulador solar, assim como uma células solar nossa (com FSF e sem "cap layer" extremamente dopado) que recebeu uma camada antirreflexiva (ARC) de $\mathrm{Al}_{2} \mathrm{O}_{3}$.

Tabela 9: Comparação entre mesas com o mesmo número de "fingers"(2) e com a mesma área iluminada (2 mm de lado).

\begin{tabular}{|l|c|c|c|}
\hline Amostra & Mesa & Fill factor & Eficiência máxima \\
\hline CS-Referência & & $77,08 \%$ & $20,15 \%$ \\
\hline CS-GaAs & B04 & $70,66 \%$ & $10,61 \%$ \\
\hline CS-FSF & B03 & $76,60 \%$ & $11,56 \%$ \\
\hline CS-F\&BSF & B03 & $75,89 \%$ & $11,53 \%$ \\
\hline CS-QDSK & B04 & $69,58 \%$ & $7,76 \%$ \\
\hline CS-FSF sem cap layer & B03 & $76,82 \%$ & $13,62 \%$ \\
\hline CS-FSF sem cap layer e com ARC & B03 & $76,57 \%$ & $16,25 \%$ \\
\hline
\end{tabular}


I) Quando comparamos a CS-FSF com a CS-GaAs, podemos constatar que o FSF melhorou a eficiência das CSs em razão do aumento da corrente de curto circuito.

II) Quando comparamos a CS-F\&BSF com a CS-FSF, observamos que as duas curvas $\mathrm{JxV}$ são praticamente idênticas, confirmando que não houve melhora.

III) Quando scomparamos a CS-QDSK com a CS-FSF, pode ser constatado que houve uma queda da corrente de curto circuito com a introdução dos QDs, mas a principal razão da redução de $32,87 \%$ na eficiência vem da forte diminuição da tensão de circuito aberto que está relacionada com o aumento do número de defeitos.

IV) Comparando a CS-FSF sem "cap layer" com a CS-FSF (com "cap layer"), fica claro que houve uma melhora na eficiência devido à remoção da camada cap dopada que aumentou tanto a corrente de curto quando a tensão de circuito aberto.

V) Quando são comparadas a CS-FSF sem "cap layer" e com ARC com a CS-FSF sem "cap layer", observa-se que a camada antirreflexiva aumentou consideravelmente a corrente de curto, aproximando esta célula da célula de GaAs comercial. Trata-se apenas de um resultado preliminar, pois nosso grupo ainda está otimizando esse tipo de filme, variando a espessura e a natureza (material) dele.

VI) Quando observamos os valores do FF de todas essas células, verifica-se que eles são geralmente parecidos com o valor da célula comercial $(77,08 \%)$, exceto no caso da CS-GaAs $(70,66 \%)$ e CS-QDSK $(69,59 \%)$. Isso está relacionado com os valores das resistências de shunt e de série. Como a resistência de shunt é inversamente proporcional ao coeficiente angular da curva $J_{X} V$ na origem $(V=0 V)$, fica claro que a CS-QDSK possui uma resistência de shunt longe do ideal (quanto maior melhor), provavelmente em razão da alta densidade de defeitos relacionada com a formação dos QDs. As outras células parecem possui uma resistência shunt razoavelmente alta, deixando as curvas $\mathrm{JxV}$ perto da horizontal na origem. A resistência de série é inversamente proporcional ao coeficiente angular da curva $\mathrm{JxV}$ no valor de tensão de circuito aberto. De maneira geral, podemos ver que nossas células solares possuem uma resistência de série maior que a da célula comercial, o que é consistente com o que já observamos nas medidas de TLM que concluíram que ainda havia necessidade de otimizar os dois contatos, mas principalmente o contato superior na camada do tipo p. 


\section{Considerações Finais}

Foram discutidos alguns tópicos essenciais para uma melhor compreensão do funcionamento das células solares e dos procedimentos necessários para a sua construção. Como se tratava de uma nova linha de pesquisa no grupo, no decorrer do trabalho, lidamos com a falta de procedimentos otimizados ou mesmo a ausência total de qualquer conhecimento, o que nos obrigou a investir muito tempo nas etapas iniciais. Também não existiam parcerias com outras pessoas, grupos e laboratórios relacionados com o tema, como há agora, por exemplo, com vários cientistas do LNNano de Campinas, da PUC-Rio, da UFRJ e de outros departamentos dentro da própria USP. Com um maior domínio das técnicas, do uso dos materiais e dos equipamentos, além das parcerias que nasceram, grande parte dos problemas foi superada. Por tanto, as condições atuais do LNMS/USP e esse trabalho servirão certamente para o desenvolvimento de novas técnicas e a incorporação de novos elementos na produção dos próximos dispositivos fotovoltaicos que serão criados pelo grupo, podendo fazer com que a eficiência das CSs produzidas melhore ainda mais. Como exemplo dos esforços mais recentes do grupo nesse sentido, estamos montando um experimento para medir a eficiência quântica e estamos investigando a incorporação de filmes anti-reflexivos.

Para atender os objetivos desse trabalho, investigamos o efeito da introdução de algumas estruturas simples nas células solares, a partir de uma estrutura padrão PIN básica de CS formada apenas por GaAs, utilizada como referência. As estruturas introduzidas foram camadas de AlGaAs para atuar como FSF e BSF, assim como camadas de QDs de InAs. As amostras foram processadas numa sala limpa com 3 máscaras (desenhadas por um grupo da PUC-Rio), e usando processos fotolitográficos positivos e, pela primeira vez em nosso grupo, também negativos. Aprendemos também a construir contatos ôhmicos especiais para as camadas do tipo $\mathrm{P}$ e do tipo $\mathrm{N}$, que são essenciais para uma boa circulação da corrente elétrica no dispositivo.

Devido ao fato de o processo de fabricação das CSs envolver muitas etapas de manufatura e o espaço amostral ter sido pequeno, pode ser que os resultados não representem os melhores valores possíveis. Por isso, é de extrema importância a necessidade de se produzir mais células para que possamos ter uma estatística mais robusta e afirmar melhor algumas indicações desse trabalho. No entanto, isso será deixado para a continuação desse estudo em nível de doutorado. A necessidade de uma quantidade maior de células de um tipo específico (tamanho e número de "fingers" fixo e otimizado) já foi percebida, e novas máscaras já estão sendo planejadas e serão construídas nos próximos meses em parceria com o LNnano, em Campinas. Uma análise prévia dos dados sugere que células de 2 ou $3 \mathrm{~mm}$ de lado, com poucos "fingers" costumam levar a maiores eficiências, o que está relacionado com o fato de que células grandes possuem uma maior probabilidade de apresentar defeitos de crescimento ou processamento, enquanto que um número alto de "fingers" diminui a área opticamente ativa do dispositivo sem melhorar a captura dos portadores. A vantagem de se construir uma máscara com um padrão de várias células de $2 \mathrm{~mm}$ de lado é que, com a construção de um número maior de dispositivos a serem testados, teremos melhores condições de realizar as afirmações dos nossos estudos.

Com as eficiências muito baixas obtidas inicialmente, da ordem de $2 \%$, verificamos a importância de se construir contatos com ligas especiais para cada tipo de contato, além de um desenho mais adequado do contato superior (na forma de "fingers"). Fomos capazes de melhorar nossos contatos pela deposição de ligas de Ni/Ge/Au para as camadas do tipo N, e de Ti/Pt/Au para as camadas do tipo P, diminuindo assim consideravelmente a barreira Schottky, conforme mostraram as medidas por TLM. No entanto, ainda precisamos trabalhar na otimização dessas ligas para diminuir ainda mais as resistências e melhorar a eficiência das nossas células solares. 
A otimização da célula de referência de GaAs ocorreu principalmente pela adição de uma camada de AlGaAs no topo da estrutura, destinada a limitar a fuga dos portadores fotogerados para a superfície, assim como pela remoção do "cap layer" altamente dopado (que é necessário para a boa qualidade dos contatos elétricos na camada tipo P) da região superficial opticamente ativa da célula, pois absorve uma parte não desprezível da radiação incidente, o que levou nossa melhor célula solar de GaAs a uma eficiência superior a $14 \%$. Porém ficou também claro que a fina camada de AlGaAs (janela) deve ter um maior teor de Al para que o seu gap seja o mais alto possível e que ela possa deixar passar uma maior parte do espectro solar, o que aumentará ainda mais a eficiência da célula de referência. Uma outra melhoria simples de ser implementada seria o aumento da espessura da região intrínseca da junção PIN para que haja uma maior absorção da radiação solar no meio da região ativa.

$\mathrm{Na}$ análise do efeito da introdução dos pontos quânticos na região ativa da célula de referência de GaAs, observamos uma piora na eficiência da ordem de $40 \%$, provavelmente relacionada à tensão mecânica acumulada devido à diferença de parâmetros de rede entre o GaAs e o InAs, que pode introduzir mais defeitos estruturais e levar mais QDs a relaxarem, sendo que uma dopagem incorreta talvez possa também contribuir. A literatura sugere que QDs produzidos pela deposição de 2,0 MC de InAs (em vez de 2.2 MC, em nosso caso) e dopagens mais altas dos QDs possa melhorar sensivelmente a eficiência [112]. Além disso, os QDs devem estar localizados na parte inferior da região ativa para que a radiação com energia maior que a do gap de GaAs seja absorvida na parte superior da região ativa, sem a presença de defeitos oriundos da tensão elástica gerada pelos QDs que podem piorar a qualidade do material nessa região e prejudicar a absorção, e, também, para que a radiação com energia abaixo do valor do gap possa ser absorvida apenas na região inferior da célula. 


\section{Referências}

1. MOHR, P. J.; TAYLOR, B. N.; NEWELL, D. B. CODATA Recommended Values of the Fundamental Physical Constants: 2014. Journal of Physical and Chemical Reference Data, n. 45, 2016.

2. REN21 SECRETARIAT. Renewables 2018 Global Status Report. REN, Paris, 2018.

3. www.absolar.org.br, 09 nov. 2018. Disponivel em: <http://www.absolar.org.br/noticia/artigos-daabsolar/por-que-querem-impedir-o-crescimento-da-energia-solar-fotovoltaica.html>.POR QUE QUEREM IMPEDIR O CRESCIMENTO DA ENERGIA SOLAR FOTOVOLTAICA?

4. www.absolar.org.br, 22 nov. 2018. Disponivel em: <http://www.absolar.org.br/noticia/noticiasexternas/voce-ja-pensou-em-trocar-a-energia-eletrica-fornecida-pela-concessionaria-pela-energiasolar-apesar-.html>. INSTALAÇÃO DE PAINÉIS SOLARES PODE REDUZIR A CONTA DE LUZ.

5. DR. PHILLIPS,. Earth at Perihelion. NASA SCIENCE: SHARE THE SCIENCE, 28 mar. 2019. Disponivel em: <https://science.nasa.gov/science-news/science-at-nasa/2001/ast04jan_1>. Acesso em: 28 mar. 2019.

6. NASA Goddard Space Flight Center, 2000. Disponivel em:

<https://earthobservatory.nasa.gov/features/Milankovitch/milankovitch_2.php>. Acesso em: 28 mar. 2019

7. MAZZIO, K. A.; LUSCOMBE, C. K. The future of organic photovoltaics. Chem. Soc. Rev., v. 44, n. 1, p. 78-90, 2015. Disponivel em: 〈http://dx.doi.org/10.1039/C4CS00227J>.

8. DE VOS, A. Detailed Balance Limit of the Efficiency of Tandem Solar Cells. Journal of Physics D: Applied Physics, v. 13, p. 839, nov. 2000.

9. WWW.NREL.GOV. Reference Solar Spectral Irradiance: ASTM G-173. Disponivel em: <https://rredc.nrel.gov/solar//spectra/am1.5/ASTMG173/ASTMG173.html>.

10. MATTHIAS , L., 14 mar. 2010. Disponivel em: <http://www.ez2c.de/ml/solar_land_area/>. Acesso em: 28 mar. 2019.

11. www.nyserda.ny.gov, 16 out. 2010. Disponivel em: <https://www.nyserda.ny.gov/-/media/Files/Publications/Research/Biomass-Solar-Wind/ny-pvmarket-trends>. Acesso em: 28 mar. 2019.

12. www.shell.com, 2017. Disponivel em: $<$ https://www.shell.com/energy-and-innovation/the-energy-future/scenarios/shell-scenariosenergy-models/world-energymodel/_jcr_content/par/textimage.stream/1510344160326/d62f12b8fe88e85dc3349c38b1ca5e44c c22c5ccc6f70beed634020cfb527c82/shell-world-energy-mo>. Acesso em: 28 mar. 2019.

13. www.iea.org, 2018. Disponivel em: $<$ https://www.iea.org/statistics/?country=WORLD\&year=2016\&category=Electricity\&indicator= TPESbySource \&mode $=$ chart $\&$ dataTable=INDICATORS $>$. Acesso em: 28 mar. 2019.

14. www.iea.org, 2019. Disponivel em: 〈https://www.iea.org/statistics/electricity/>. Acesso em: 28 mar. 2019.

15. www.absolar.org.br, 19 dez. 2018. Disponivel em: <http://www.absolar.org.br/noticia/noticiasexternas/gestao-ambiental-setor-de-energia-renovavel-gera-mais-de-10-milhoes-de-empregos-nomundo-diz-estudo.html>. Acesso em: 28 mar. 2019. GESTÃO AMBIENTAL: SETOR DE ENERGIA RENOVÁVEL GERA MAIS DE 10 MILHÕES DE EMPREGOS NO MUNDO, DIZ ESTUDO. 
16. SHOCKLEY, W.; QUEISSER, H. J. Detailed balance limit of efficiency of p-n junction solar cells. Journal of applied physics, v. 32, p. 510-519, 1961.

17. PETERS, I. M.; BUONASSISI, T. Energy Yield Limits for Single-Junction Solar Cells. Joule, v. 2, p. 1160-1170, 2018. ISSN ISSN: 2542-4351. Disponivel em:

<http://www.sciencedirect.com/science/article/pii/S2542435118300989>.

18. www.ise.fraunhofer.de, 14 mar. 2019. Disponivel em: $<$ https://www.ise.fraunhofer.de/content/dam/ise/de/documents/publications/studies/PhotovoltaicsReport.pdf>. Acesso em: 28 mar. 2019.

19. www.nrel.gov, 03 jan. 2019. Disponivel em: <https://www.nrel.gov/pv/assets/pdfs/pv-efficiencychart.20190103.pdf >. Acesso em: 28 mar. 2019.

20. www.portalsolar.com.br. Disponivel em:

<https://www.portalsolar.com.br/blog-solar/energia-solar/italia-lanca-drones-movidos-comenergia-solar.html>. Acesso em: 28 mar. 2019.

21. MERTENS, K. Photovoltaics: fundamentals, technology, and practice. [S.1.]: John Wiley \& Sons, 2018.

22. BECQUEREL, A. E. Recherches sur les effets de la radiation chimique de la lumiere solaire au moyen des courants electriques. Comptes Rendus de LAcademie des Sciences, v. 9, p. 145-149, 1839.

23. GREEN, M. A. Photovoltaic principles. Physica E: Low-dimensional Systems and Nanostructures, v. 14, p. 11-17, 2002.

24. FERNANDES, A. D. A. Desenvolvimento de um rastreador de baixo custo para sistemas de energia fotovoltáicos. [S.1.]: [s.n.], 2019. Disponivel em:

<http://repositorio.ufba.br/ri/handle/ri/28758>. Acesso em: 29 mar. 2019. Dissertações de Mestrado (PPEE).

25. WESTON, E. Apparatus for utilizing solar radiant energy. United States Patent Office, 1888. Disponivel em: <https://patentimages.storage.googleapis.com/1f/55/8f/4f4605a0c953a2/US389124.pdf>.

26. A. B., A.; M. B., P. Einstein's Proposal of the Photon Concept - a Translation of the Annalen der Physik Paper of 1905. American Journal of Physics, Amherst, 02 dez. 1964. Disponivel em: $\langle$ http://astro1.panet.utoledo.edu/ ljc/PE_eng.pdf $>$.

27. LANGE, B. Magic Plates Tap Sun for Power. Popular Science Monthly, v. 118, p. 41, 1931.

28. OHL, R. S. Light-Senstive Electric Device. New: [s.n.], 1941. Disponivel em: $<$ https://patentimages.storage.googleapis.com/d3/8b/71/374769ceefb2fa/US2402662.pdf>. United States Patent Office 2,402,662.

29. BLANCO, J.; MALATO, S. Solar Energy Conversion And Photoenergy System-Volume II. [S.1.]: EOLSS Publications, v. 8, 2009.

30. history.nasa.gov. Disponivel em: <https://history.nasa.gov/SP-4202/chap12.html\#p12-224>. Acesso em: 29 mar. 2019.

31. FATEMI, N. S. et al. Performance of high-efficiency advanced triple-junction solar panels for the LILT Mission Dawn. Conference Record of the Thirty-first IEEE Photovoltaic Specialists Conference, 2005. [S.1.]: [s.n.]. 2005. p. 618-621.

32. COMMONS, W. File:Dawn's second solar panel.jpg --- Wikimedia Commons, the free media repository, 2017. Disponivel em:

<https://commons.wikimedia.org/w/index.php?title=File:Dawn\%27s_second_solar_panel.jpg\&old id=231677118> . [Online; accessed 29-March-2019].

33. SPELLMAN, F. R. The science of renewable energy. [S.1.]: CRC Press, 2016. 
34. SERREZE, H. B. Optimizing Solar Cell Performance by Simultaneous Consideration of Grid Pattern Design and Interconnect Configurations. Washington, D.C., USA: [s.n.]. 1978. p. 1-8.

35. www.pveducation.org/. Disponivel em: <https://www.pveducation.org/pvcdrom/design-of-silicon-cells/metal-grid-pattern>. Acesso em: 30 mar. 2019.

36. MURDICK, D. et al. Predicting surface free energies with interatomic potentials and electron counting. J. Phys.: Condens. Matter, v. 17, p. 6123-6137, out. 2005.

37. SINTRA,. www.google.com. Disponivel em: <https://www.google.com/imgres?imgurl=https $\% 3 \mathrm{~A} \% 2 \mathrm{~F} \% 2 \mathrm{Fslideplayer.com.br} \% 2 \mathrm{Fslide} \% 2 \mathrm{~F} 514$ 8954\%2F16\%2Fimages\%2F15\%2FEstrutura\%2Bde\%2Bbandas\%2Bde\%2Benergia.jpg\&imgrefur $\mathrm{l}=\mathrm{https} \% 3 \mathrm{~A} \% 2 \mathrm{~F} \% 2 \mathrm{Fslideplayer.com} . \mathrm{br} \% 2 \mathrm{Fslide} \% 2 \mathrm{~F} 5148954 \% 2 \mathrm{~F} \&$ docid=X29P_BFnOcQ5MM \&tbnid $=$ FvQNoTAVDYon>.

38. LUNDSTROM, M. nanohub.org, 2011. Disponivel em: <https://nanohub.org/resources/11884/download/2011.07.20-NCN-SC01-Lundstrom.pdf〉. Acesso em: 29 mar. 2019.

39. SWART, J. W. Materiais elétricos: fundamentos e semicondutores. CAMPINAS: UNICAMP, 2004.

40. MISHRA, U.; SINGH, J. Semiconductor device physics and design. [S.1.]: Springer Science \& Business Media, 2007.

41. www.ujaen.es/investiga/solar/07cursosolar, 29 mar. 2019. Disponivel em: <http://www.ujaen.es/investiga/solar/07cursosolar/home_main_frame/03_celula/01_basico/images /curva_i-v.gif>. Acesso em: 29 mar. 2019.

42. SEABRA, A. C. edisciplinas.usp.br. Disponivel em: <https://edisciplinas.usp.br/pluginfile.php/3474213/mod_resource/content/7/PSI3321-A16.pdf>.

43. COELHO, P. D. A. C. V. sites.poli.usp.br/d/pmt2100/, 2005. Disponivel em: <http://sites.poli.usp.br/d/pmt2100/Aula04_2005\%201p.pdf>. Acesso em: 29 mar. 2019.

44. MEYER, E. L. Extraction of saturation current and ideality factor from measuring Voc and Isc of photovoltaic modules. International Journal of Photoenergy, v. 2017, 2017.

45. BAYHAN, H.; BAYHAN, M. A simple approach to determine the solar cell diode ideality factor under illumination. Solar Energy, v. 85, p. 769-775, 2011.

46. HUMADA, A. M. et al. Solar cell parameters extraction based on single and double-diode models: A review. Renewable and Sustainable Energy Reviews, v. 56, p. 494-509, 2016.

47. www.pveducation.org, 2019. Disponivel em: <https://www.pveducation.org/pvcdrom/characterisation/measuring-ideality-factor>. Acesso em: 29 mar. 2019.

48. ROBINSON, S. J.; ABERLE, A. G.; GREEN, M. A. Recombination saturation effects in silicon solar cells. IEEE Transactions on Electron Devices, v. 41, p. 1556-1569, set. 1994. ISSN ISSN: 0018-9383.

49. NUSSBAUM, A. Generation-recombination characteristic behavior of silicon diodes. physica status solidi (a), v. 19, p. 441-450, 1973.

50. SINGULANI, A. P. Simulation and design of GaAs/AlGaAs quantum well solar cells aided by genetic algorithm. PUC-RIO - Pontifícia Universidade Católica do Rio de Janeiro. Disponivel em: <https://www.maxwell.vrac.puc-rio.br/15317/15317_3.PDF>. PUC-Rio-Certificação Digital $\mathrm{N}^{\circ} 0721357 / \mathrm{CA}$.

51. TUNG, R. T. The physics and chemistry of the Schottky barrier height. Applied Physics Reviews, v. 1, p. 011304, 2014.

52. MOURA, V. A. A barreira Schottky na interface Al: nGaAs preparada por MBE, 1992. 
53. DOOLITTLE, A. ECE 4813. Disponivel em: 〈http://alan.ece.gatech.edu/ECE4813/Lectures/Lecture6B_RecombinationGeneration.pdf〉.

54. KIM, D. Schottky Barrier Formation. Disponivel em: $<$ http://large.stanford.edu/courses/2007/ap272/kimdh1/>.

55. WEINER, E. C. Células Solares de Banda Intermediária de Pontos Quânticos Baseadas em InAs/GaAs/AlGaAs. Rio de Janeiro: [s.n.], 2015. Disponivel em: <http://www.dbd.puc-rio.br/pergamum/tesesabertas/1321801_2015_completo.pdf >. Acesso em: 20 mar. 2019. Pontifícia Universidade Católica do Rio de Janeiro.

56. MAIA, Á. D. B. Crescimento, fabricação e teste de fotodetectores de radiação infravermelha baseados em pontos quânticos. Universidade de São Paulo. [S.1.]. 2012.

57. dvh.physics.illinois.edu. Disponivel em: <http://dvh.physics.illinois.edu/pdf/AZ5214E.pdf>. Acesso em: 30 mar. 2019.

58. AMARAL, R. N. P. D. Síntese e caracterização de fotocatalisadores nanoestruturados de TTNT e Ag3Po4 ativos no espectro visível. Rio de Janeiro: [s.n.], 2016. Projeto de Graduação necessário à obtenção do título de Engenheiro de Materiais.

59. STANDARD, A. S. T. M. G173-03 (reapproved 2012), standard tables for reference solar spectral irradiances: Direct normal and hemispherical on 37 tilted surface. West Conshohocken, PA: ASTM International, 2012.

60. GREEN, M. A. Limiting photovoltaic efficiency under new ASTM International G173-based reference spectra. Progress in Photovoltaics: Research and Applications, v. 20, p. 954-959, 2012.

61. RICHARDS, B. S. Enhancing the performance of silicon solar cells via the application of passive luminescence conversion layers. Solar energy materials and solar cells, v. 90, p. 2329-2337, 2006.

62. BIRD, R. E.; RIORDAN, C. Simple solar spectral model for direct and diffuse irradiance on horizontal and tilted planes at the earth's surface for cloudless atmospheres. Journal of climate and applied meteorology, v. 25, p. 87-97, 1986.

63. BIRD, R. E. et al. Solar spectral measurements in the terrestrial environment. Applied Optics, v. 21, p. 1430-1436, 1982.

64. www.nrel.gov. Disponivel em: <https://www.nrel.gov/grid/solar-resource/spectra-am1.5.html>. Acesso em: 30 mar. 2019.

65. RÜHLE, S. Tabulated values of the Shockley--Queisser limit for single junction solar cells. Solar Energy, v. 130, p. 139-147, 2016.

66. MICHA, D. N. Estudo de alternativas para minimização de perdas em dispositivos fotovoltaicos de GaAs. Rio de Janeiro: Instituto de Física, UFRJ, 2015.

67. SEMONIN, O. E.; LUTHER, J. M.; BEARD, M. C. Quantum dots for next-generation photovoltaics. Materials Today, v. 15, p. 508-515, 2012.

68. TANABE, K. A review of ultrahigh efficiency III-V semiconductor compound solar cells: multijunction tandem, lower dimensional, photonic up/down conversion and plasmonic nanometallic structures. Energies, v. 2, p. 504-530, 2009.

69. OKADA, Y. et al. Intermediate band solar cells: Recent progress and future directions. Applied Physics Reviews, v. 2, p. 021302, 2015. Disponivel em: 〈https://doi.org/10.1063/1.4916561 >.

70. ARAKAWA, Y.; SAKAKI, H. Multidimensional quantum well laser and temperature dependence of its threshold current. Applied Physics Letters, v. 40, p. 939-941, 1982. Disponivel em: <https://doi.org/10.1063/1.92959>.

71. LEONARD, D. et al. Direct formation of quantum-sized dots from uniform coherent islands of InGaAs on GaAs surfaces. Applied Physics Letters, v. 63, p. 3203-3205, 1993. Disponivel em: $<$ https://doi.org/10.1063/1.110199 >.

72. CHIQUITO, A. J. Pontos quânticos: átomos artificiais e transistores atômicos. Revista Brasileira de Ensino de Física, jun. 2001. Disponivel em: 
<http://dx.doi.org/10.1590/S1806-11172001000200004>. Rev. Bras. Ensino Fís. vol.23 no.2 São Paulo June 2001.

73. LAM, P. et al. Voltage recovery in charged InAs/GaAs quantum dot solar cells. Nano Energy, v. 6, p. 159-166, 2014. ISSN ISSN: 2211-2855. Disponivel em: <http://www.sciencedirect.com/science/article/pii/S2211285514000548>.

74. KASH, K. Optical properties of III-V semiconductor quantum wires and dots. Journal of Luminescence, v. 46, p. 69-82, mar. 1990.

75. NEE, T.-E. et al. Temperature and Excitation Dependence of Photoluminescence Spectra of InAs/GaAs Quantum Dot Heterostructures. 2006 IEEE Conference on Emerging Technologies - Nanoelectronics. [S.1.]: [s.n.]. jan. 2006. p. 433-437.

76. LI, S. S. Theoretical analysis of a novel MPN gallium arsenide Schottky barrier solar cell. SolidState Electronics, v. 21, p. 435-438, 1978.

77. www.ioffe.ru. Disponivel em: <http://www.ioffe.ru/SVA/NSM/Semicond/AlGaAs/bandstr.html>. Acesso em: 30 mar. 2019.

78. SILVA, Marcelo Jacob da. Crescimento e Caracterização de Pontos Quânticos de InAs Autoformados. 1999. Dissertação (Mestrado em Física do Estado Sólido) - Instituto de Física, Université de São Paulo, São Paulo, 1999. doi:10.11606/D.43.2017.tde-13032017-121314. Acesso em: 201905-23.

79. TSAO, J. Y. Materials fundamentals of molecular beam epitaxy. [S.1.]: Academic Press, 2012.

80. en.wikipedia.org. Disponivel em: <https://en.wikipedia.org/wiki/File:Photoresist_of_Photolithography.png>.

81. www.spacewx.com. Disponivel em: <http://www.spacewx.com/solar_spectrum.html >. Acesso em: 30 mar. 2019.

82. physics.nist.gov. Disponivel em: <https://physics.nist.gov/PhysRefData/Handbook/Tables/mercurytable3.htm>. Acesso em: 30 mar. 2019.

83. hyperphysics.phy-astr.gsu.edu. Disponivel em: <http://hyperphysics.phy-astr.gsu.edu/hbase/quantum/atspect2.html>. Acesso em: 30 mar. 2019.

84. Innano.cnpem.br. Disponivel em: 〈http://lnnano.cnpem.br/>. Acesso em: 30 mar. 2019.

85. ADACHI, S.; KIKUCHI, D. Chemical etching characteristics of GaAs (100) surfaces in aqueous HF solutions. Journal of The Electrochemical Society, v. 147, p. 4618-4624, 2000.

86. angstromengineering.com. Disponivel em: <https://angstromengineering.com/products/nexdep/>. Acesso em: 30 mar. 2019.

87. www.crystec.com. Disponivel em: <https://www.crystec.com/kllrtpe.htm〉. Acesso em: 30 mar. 2019.

88. en.wikipedia.org. Disponivel em: <https://en.wikipedia.org/wiki/Rapid_thermal_processing\#cite_ref-1>. Acesso em: 30 mar. 2019.

89. allwin21.com/. Disponivel em: <https://allwin21.com/accuthermo-aw-610/>. Acesso em: 30 mar. 2019.

90. allwin21.com/. Disponivel em: <https://allwin21.com/about/>. Acesso em: 30 mar. 2019.

91. allwin21.com/. Disponivel em: <https://allwin21.com/wp-content/uploads/2006/11/Allwin21_AccuThermo_AW-610.pdf>. Acesso em: 30 mar. 2019.

92. www.cascademicrotech.com. Disponivel em: <https://www.cascademicrotech.com/products>. Acesso em: 30 mar. 2019.

93. www.formfactor.com/. Disponivel em:

$<$ https://www.formfactor.com/products/probe-systems/?_probe_systems=systems-products-mps $>$. 
94. ABBAS, T.; SLEWA, L. Transmission line method (TLM) measurement of (metal/ZnS) contact resistance. Int. J. Nanoelectronics and Materials, v. 8, p. 111-120, 2015.

95. HEIBLUM, M.; NATHAN, M. I.; CHANG, C. A. Characteristics of AuGeNi ohmic contacts to GaAs. Solid-State Electronics, v. 25, p. 185-195, 1982.

96. tuttle.merc.iastate.edu. Disponivel em: $\langle$ http://tuttle.merc.iastate.edu/ee432/topics/metals/tlm_measurements.pdf $>$. Acesso em: 30 mar. 2019.

97. GROVER, S. Effect of Transmission Line Measurement (TLM) Geometry on Specific Contact Resistivity Determination, 2016.

98. nano.boisestate.edu, 2010. Disponivel em: <http://nano.boisestate.edu/wp-content/uploads/2010/12/NANOSCOPE-V-CONTROLLERUSING-NANOSCOPE-8-SOFTWARE-D-004-1030-000.pdf>. Acesso em: 30 mar. 2019.

99. LAMAS, T. E. Epitaxia por feixe molecular de camadas dopadas do tipo p para a construção de dispositivos optoeletrônicos. Universidade de São Paulo. [S.l.]. 2004.

100 CANAÚO, P. P. L. M.; FILHO, A. C. D. M. Medição De Eficiência Quântica e sensibilidade Radiante Em Dispositivos Optoeletrônicos. [S.1.]: [s.n.]. Disponivel em: <http://rmct.ime.eb.br/arquivos/RMCT_2_quad_2000/med_efic_quant_sens_radiante.pdf>.

101 SALII, R. A. et al. Increasing the quantum efficiency of GaAs solar cells by embedding InAs . quantum dots. Journal of Physics: Conference Series. [S.1.]: [s.n.]. 2016. p. 012036.

102 VETRITTI, L. B. Determinação da responsividade de fotodetectores de radiação . infravermelha. [S.1.]. Relatório de fianl do programade de iniciação científica do Instituto de Física da Universidade de São Paulo.

103 abet-technologies.com. Disponivel em: <http://abet-technologies.com/solar-simulators/>. Acesso . em: 30 mar. 2019.

104 abet-technologies.com. Disponivel em: <http://abet-technologies.com/solar-simulators/solar. simulator-elements/>.

105 abet-technologies.com. Disponivel em:

. 〈http://abet-technologies.com/wp-content/uploads/Reference-cells-10-2014.pdf>. Acesso em: 30 mar. 2019.

106 abet-technologies.com. Disponivel em: . 〈http://abet-technologies.com/wp-content/uploads/tracermanual.pdf>. Acesso em: 30 mar. 2019.

107 ROBINSON, G. Y. Schottky diodes and ohmic contacts for the III-V semiconductors. In: . Physics and chemistry of III-V compound semiconductor interfaces. [S.1.]: Springer, 1985. p. 73-163.

108 SELDERS, J.; EMEIS, N.; BENEKING, H. Schottky-barriers on p-type GaInAs. IEEE . Transactions on Electron Devices, v. 32, p. 605-609, 1985.

$109 \mathrm{CHU}, \mathrm{S}$. N. G. et al. Interfacial microstructure and electrical properties of the Pt/Ti ohmic contact . in p-In0. 53Ga0. 47As formed by rapid thermal processing. Journal of applied physics, v. 67, p. 3754-3760, 1990.

110 WEINER, E. C. et al. Effect of capping procedure on quantum dot morphology: Implications on . optical properties and efficiency of InAs/GaAs quantum dot solar cells. Solar Energy Materials and Solar Cells, v. 178, p. 240-248, 2018. ISSN ISSN: 0927-0248. Disponivel em: <http://www.sciencedirect.com/science/article/pii/S092702481830028X>.

111 HAN, I. S. et al. Efficiency limit of InAs/GaAs quantum dot solar cells attributed to quantum dot . size effects. Solar Energy Materials and Solar Cells, v. 155, p. 70-78, 2016. ISSN ISSN: 09270248. Disponivel em: <http://www.sciencedirect.com/science/article/pii/S0927024816300812>. 
112 YANG, X. et al. Improved efficiency of InAs/GaAs quantum dots solar cells by Si-doping. Solar . Energy Materials and Solar Cells, v. 113, p. 144-147, 2013. ISSN ISSN: 0927-0248. Disponivel em: <http://www.sciencedirect.com/science/article/pii/S0927024813000676>.

113 HAAG, R. Estimativa da distribuição espectral da radiação solar sobre o território brasileiro através . de análise multiinstrumental, 2012. Disponivel em: <http://hdl.handle.net/10183/56588>. Tese de doutorado.

114 LEVINSON, R.; AKBARI, H.; BERDAHL, P. Measuring solar reflectance-Part II: review of . practical methods. [S.1.]: [s.n.], 2010. Disponivel em: 〈https://escholarship.org/uc/item/0ws2384p〉. Acesso em: 30 mar. 2019.

115 Green Rhino Energy Ltd, 2016. Disponivel em: <http://www.greenrhinoenergy.com/solar/radiation/spectra.php>. Acesso em: 28 mar. 2019.

116 RÜHLE, S. Tabulated values of the Shockley-Queisser limit for single junction solar cells. Solar . Energy, v. 130, p. 139-147, 2016. ISSN ISSN: 0038-092X. Disponivel em: <http://www.sciencedirect.com/science/article/pii/S0038092X16001110>.

117 www.altadevices.com, 31 out. 2017. Disponivel em: <https://www.altadevices.com/use-gallium. arsenide-solar-cells/>. Acesso em: 28 mar. 2019.

118 DA ROSA, L. www.google.com. Disponivel em: . <https://www.google.com/imgres?imgurl=https\%3A\%2F\%2Fslideplayer.com.br\%2Fslide\%2F514 $8954 \% 2 \mathrm{~F} 16 \% 2 \mathrm{Fimages} \% 2 \mathrm{~F} 15 \% 2 \mathrm{FEstrutura} \% 2 \mathrm{Bde} \% 2 \mathrm{Bbandas} \% 2 \mathrm{Bde} \% 2 \mathrm{Benergia}$.jpg\&imgrefur $\mathrm{l}=\mathrm{https} \% 3 \mathrm{~A} \% 2 \mathrm{~F} \% 2 \mathrm{Fslideplayer.com} . \mathrm{br} \% 2 \mathrm{Fslide} \% 2 \mathrm{~F} 5148954 \% 2 \mathrm{~F} \&$ docid=X29P_BFnOcQ5MM \&tbnid=FvQNoTAVDYon>.

119 SINTRA, C. B. www.google.com. Disponivel em: . <https://www.google.com/imgres?imgurl=https\%3A\%2F\%2Fslideplayer.com.br\%2Fslide\%2F514 $8954 \% 2 \mathrm{~F} 16 \% 2 \mathrm{Fimages} \% 2 \mathrm{~F} 15 \% 2 \mathrm{FEstrutura} \% 2 \mathrm{Bde} \% 2 \mathrm{Bbandas} \% 2 \mathrm{Bde} \% 2 \mathrm{Benergia} . j p g \& i m g r e f u r$ $\mathrm{l}=\mathrm{https} \% 3 \mathrm{~A} \% 2 \mathrm{~F} \% 2 \mathrm{Fslideplayer} . \mathrm{com} . \mathrm{br} \% 2 \mathrm{Fslide} \% 2 \mathrm{~F} 5148954 \% 2 \mathrm{~F} \&$ docid=X29P_BFnOcQ5MM \&tbnid $=$ FvQNoTAVDYon>.

120 KHANNA, V. et al. A three diode model for industrial solar cells and estimation of solar cell . parameters using PSO algorithm. Renewable Energy, v. 78, p. 105-113, 2015.

$121 \mathrm{SMITH}, \mathrm{R}$. P. et al. Efficiency limit of InAs/GaAs quantum dot solar cells attributed to quantum dot . size effects. Solar Energy Materials and Solar Cells, v. 155, p. 70-78, 2016. Disponivel em: <https://doi.org/10.1016/j.solmat.2016.04.045>.

122 SHOCKLEY, W.; QUEISSER, H. J. Detailed Balance Limit of Efficiency of p-n Junction Solar . Cells. Journal of Applied Physics, v. 32, p. 510-519, 1961. Disponivel em: $<$ https://doi.org/10.1063/1.1736034 >.

123 BIMBERG, D.; POHL, U. W. Quantum dots: promises and accomplishments. Materials Today, v. 14, p. 388-397, 2011. ISSN ISSN: 1369-7021. Disponivel em:

<http://www.sciencedirect.com/science/article/pii/S1369702111701833>.

124 RAJAEI, E.; AHMADI BORJI, M. Energy Levels of InGaAs/GaAs Quantum Dot Lasers with Different Sizes. International Journal of Nanoscience and Nanotechnology, v. 12, p. 45-53, jan. 2016.

125 DARUKA, I.; BARABÁSI, A.-L. Dislocation-Free Island Formation in Heteroepitaxial Growth: A Study at Equilibrium. Phys. Rev. Lett., v. 79, n. 19, p. 3708-3711, nov. 1997. Disponivel em: <https://link.aps.org/doi/10.1103/PhysRevLett.79.3708>.

126 BACA, A. G.; ASHBY, C. I. H. Fabrication of GaAs devices. [S.1.]: IET, 2005. 


\section{Apêndice}

\subsection{Consideração sobre o uso do padrão AM1.5G}

Apesar de ser bastante utilizado na comunidade científica, devemos levar em conta as limitações apresentadas pelo padrão AM1.5G proposto pela ASTM. É de se esperar, por exemplo, que esse espectro gerado para a América do Norte não valha para regiões na América do Sul, que apresentam condições atmosféricas bastante distintas, como variação nas concentrações de gases e aerossóis de acordo com a localidade, dia e época do ano. No entanto, várias entidades da área da energia fotovoltaica continuam utilizando o padrão americano ao redor do globo, podendo levar a erros e falhas em seus projetos e pesquisas [113]. Alguns trabalhos, relatam que a distribuição espectral prevista pela norma ASTM G-173 não é representativa para várias regiões da superfície terrestre [113]. A vantagem de se utilizar um padrão mundialmente aceito, mesmo com todas as limitações do ASTM, reside na comparação de células em condições padrões de laboratório. Ou seja, o padrão ASTM torna possível a comparação de células, produzidas nas várias regiões do globo, caso operassem nas mesmas condições.

De posse dos dados de uma célula operando nas condições padrões prescritas pelo documento ASTM G-173, é possível analisar a influência que teriam as diferentes distribuições espectrais locais no seu desempenho. Essa influência pode ser descrita matematicamente através da convolução entre as respostas espectrais dos dispositivos analisados e as distribuições espectrais de cada região do globo [113]. Empregando o programa computacional SMARTS2 (Simple Model of the Atmospheric Radiative Transfer of Sunshine), utilizado na obtenção das distribuições espectrais da radiação solar descritas pela norma ASTM G-173 e as típicas em cada região analisada, e conhecendo as respostas espectrais dos dispositivos fotovoltaicos, é possível, através de uma discretização espectral, obter um fator que relaciona a mudança na eficiência do dispositivo, quando é utilizado numa região específica do globo, em relação ao padrão adotado pela norma. Para ilustrar essa variação foram feitos alguns cálculos através do SMARTS2 para alguns espectros para as cidades de Albuquerque (Novo México, EUA), Porto Alegre (Rio Grande do Sul, Brasil) e Cuiabá (Mato Grosso, Brasil) utilizando AM = 1 (Figura 115). Nota-se claramente o efeito dos aerossóis na redução da irradiância em Cuiabá, contrariando a ideia de que regiões mais próximas do Equador recebem maiores irradiâncias [113].

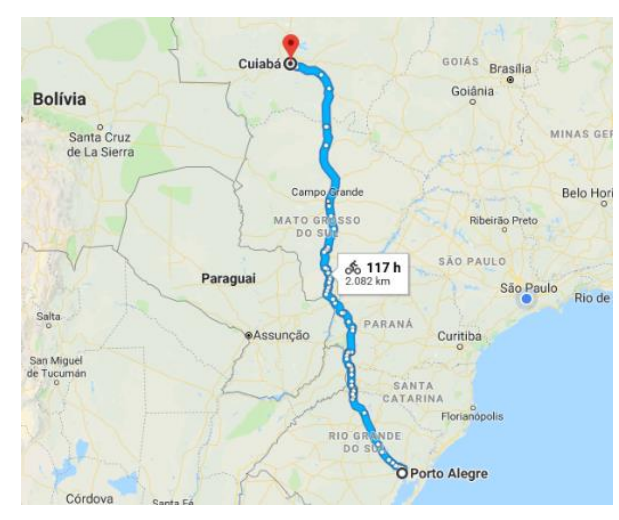

Figura 114: Localização das cidades de Cuiabá e Porto Alegre. Fonte: Google Maps.

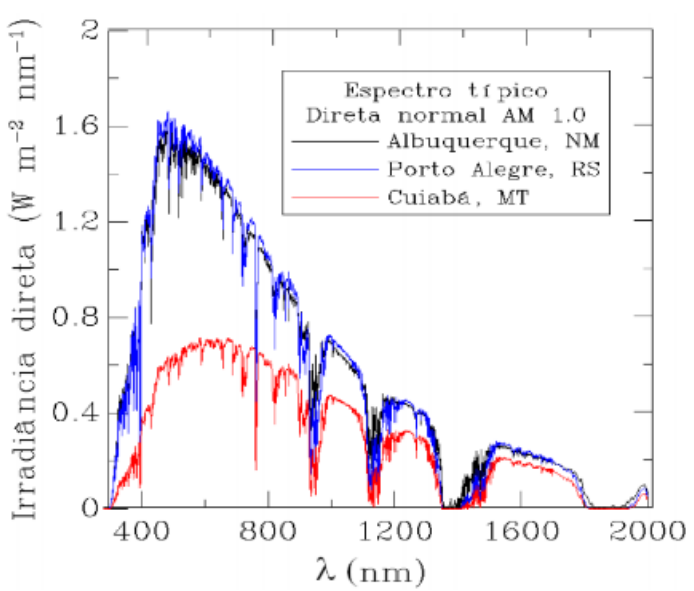

Figura 115: Irradiância espectral direta normal típica para uma massa de ar unitária em Albuquerque, NM; Porto Alegre, RS e Cuiabá, MT [113]. 
Dessa forma, um dispositivo de tecnologia de filmes finos de GaAs, fabricado pela empresa ALTA [113], pode apresentar em várias regiões do Brasil um fator de eficiência espectral maior que $100 \%$, chegando a $107 \%$ em Manaus para massas de ar acima de 1,5 [113], devido às diferenças do espectro local em relação ao ASTM G-173. A Figura 116 apresenta uma estimativa da irradiância espectral global comparada com a distribuição prevista pela norma ASTM G-173, quando empregados os dados climatológicos obtidos para os valores médios anuais de concentração de vapor de água, aerossóis, ozônio e dióxido de carbono, além das massas de ar e configurações geométricas representativas para a região de Manaus [113].

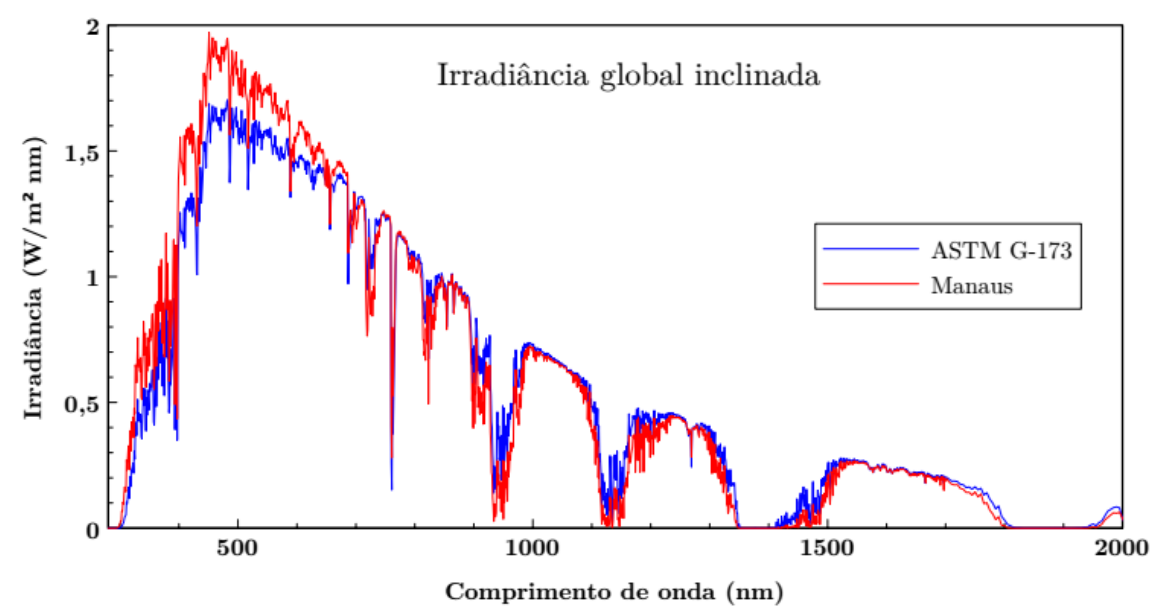

Figura 116: Espectro característico para uma superfície voltada para o norte e com inclinação de $3^{\circ}$ na cidade de Manaus, AM (vermelho) e o espectro definido pela norma ASTM G-173 (azul) [113].

Uma limitação adicional na análise das especificidades locais é que o modelo de transferência radiativa adotado no Atlas Brasileiro de Energia Solar utiliza um perfil atmosférico de aerossóis padrão para áreas continentais e não contempla a variabilidade decorrente das queimadas, por exemplo. As divergências em relação a esse modelo, devido à alta concentração de partículas de aerossóis que não é considerada, podem ser notadas em cidades como São Paulo devido à poluição industrial, ao material originado pela queima de combustíveis fósseis e, no interior do estado, em função da queima da cana-de-açúcar [113].

\subsection{Geometria da máscara para o processamento dos "fingers"}

Os detalhes do desenho da máscara utilizada nessa dissertação para o processamento dos "fingers" são mostrados na Figura 117. As menores mesas $(B 16, B 17, \ldots)$ têm um tamanho aproximado de $2 \times 2 \mathrm{~mm}^{2}$, as intermediárias (B20, B21, ...) têm um tamanho aproximado de $3 \times 3$ $\mathrm{mm}^{2}$, e as maiores $(\mathrm{B} 1, \mathrm{~B} 15, \ldots)$ têm um tamanho aproximado de $5 \times 5 \mathrm{~mm}^{2}$. A Tabela 10 traz algumas informações numéricas a respeito de cada uma das células. 


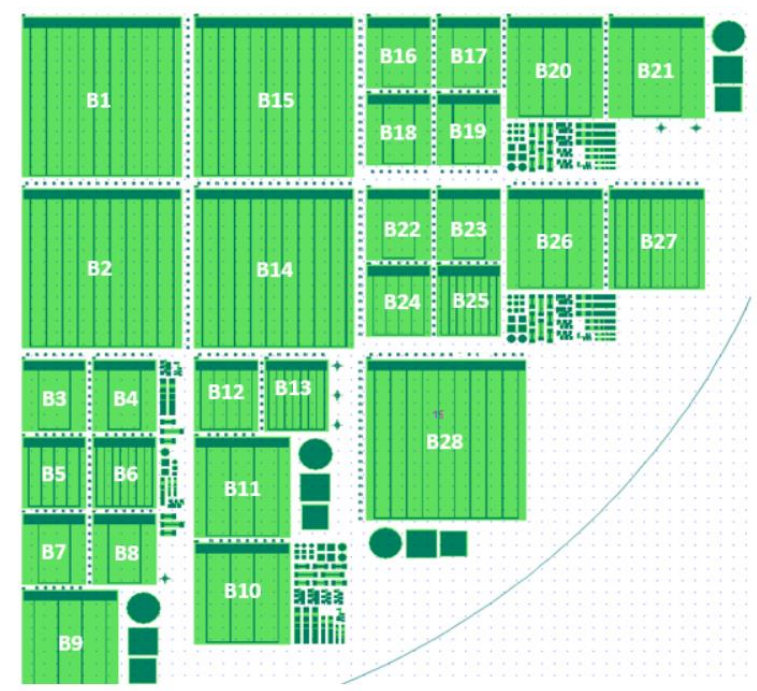

Figura 117: Quadrante utilizado da máscara [55] no processamento de todas as amostras.

Tabela 10: Detalhes das áreas das mesas e dos contatos da máscara mostrada na Figura 117.

\begin{tabular}{|c|c|c|c|c|c|c|c|c|c|}
\hline \multicolumn{6}{|c|}{ Mesas } & \multicolumn{4}{|c|}{ Contados } \\
\hline & $\begin{array}{l}\text { Largura } \\
{[\mathrm{mm}]}\end{array}$ & $\begin{array}{l}\text { Área } \\
\text { Total } \\
{\left[\mathrm{mm}^{2}\right]} \\
\end{array}$ & $\begin{array}{l}\text { Área Total } \\
\text { Iluminada } \\
{\left[\mathrm{cm}^{2}\right]}\end{array}$ & $\begin{array}{l}\% \text { da área } \\
\text { de sombra }\end{array}$ & $\begin{array}{l}\% \text { de área } \\
\text { iluminada }\end{array}$ & $\mathrm{N}^{\circ}$ & $\begin{array}{l}\text { Largura dos } \\
\text { Fingers }[\mu \mathrm{m}]\end{array}$ & $\begin{array}{l}\text { Área dos fingers } \\
{\left[\mathrm{mm}^{2}\right]}\end{array}$ & $\begin{array}{l}\text { Área dos total dos } \\
\text { contatos }\left[\mathrm{mm}^{2}\right]\end{array}$ \\
\hline B01 & 5 & 27,075 & 24,787 & $8,450 \%$ & $91,550 \%$ & 10 & 15 & 0,818 & 2,288 \\
\hline B02 & 5 & 27,075 & 24,242 & $10,464 \%$ & $89,536 \%$ & 10 & 25 & 1,363 & 2,833 \\
\hline B03 & 2 & 4,830 & 4,185 & $13,359 \%$ & $86,641 \%$ & 2 & 15 & 0,075 & 0,645 \\
\hline B04 & 2 & 4,830 & 4,185 & $13,359 \%$ & $86,641 \%$ & 2 & 15 & 0,075 & 0,645 \\
\hline B05 & 2 & 4,830 & 4,086 & $15,408 \%$ & $84,592 \%$ & 5 & 15 & 0,174 & 0,744 \\
\hline B06 & 2 & 4,830 & 3,994 & $17,318 \%$ & $82,682 \%$ & 8 & 15 & 0,266 & 0,836 \\
\hline B07 & 2 & 4,830 & 4,185 & $13,359 \%$ & $86,641 \%$ & 2 & 15 & 0,075 & 0,645 \\
\hline B08 & 2 & 4,830 & 4,185 & $13,359 \%$ & $86,641 \%$ & 2 & 15 & 0,075 & 0,645 \\
\hline B09 & 3 & 10,245 & 9,161 & $10,581 \%$ & $89,419 \%$ & 4 & 15 & 0,214 & 1,084 \\
\hline B10 & 3 & 10,245 & 9,161 & $10,581 \%$ & $89,419 \%$ & 4 & 15 & 0,214 & 1,084 \\
\hline B11 & 3 & 10,245 & 9,161 & $10,581 \%$ & $89,419 \%$ & 4 & 15 & 0,214 & 1,084 \\
\hline B12 & 2 & 4,830 & 4,086 & $15,408 \%$ & $84,592 \%$ & 5 & 15 & 0,174 & 0,744 \\
\hline B13 & 2 & 4,830 & 3,994 & $17,318 \%$ & $82,682 \%$ & 8 & 15 & 0,266 & 0,836 \\
\hline B14 & 5 & 27,075 & 23,969 & $11,471 \%$ & $88,529 \%$ & 10 & 30 & 1,636 & 3,106 \\
\hline B15 & 5 & 27,075 & 24,515 & $9,457 \%$ & $90,543 \%$ & 10 & 20 & 1,090 & 2,560 \\
\hline B16 & 2 & 4,830 & 4,185 & $13,359 \%$ & $86,641 \%$ & 2 & 15 & 0,075 & 0,645 \\
\hline B17 & 2 & 4,830 & 4,160 & $13,880 \%$ & $86,120 \%$ & 2 & 20 & 0,100 & 0,670 \\
\hline B18 & 2 & 4,830 & 4,134 & $14,402 \%$ & $85,598 \%$ & 2 & 25 & 0,126 & 0,696 \\
\hline B19 & 2 & 4,830 & 4,109 & $14,925 \%$ & $85,075 \%$ & 2 & 30 & 0,151 & 0,721 \\
\hline B20 & 3 & 10,245 & 9,161 & $10,581 \%$ & $89,419 \%$ & 4 & 15 & 0,214 & 1,084 \\
\hline B21 & 3 & 10,245 & 9,262 & $9,592 \%$ & $90,408 \%$ & 2 & 15 & 0,113 & 0,983 \\
\hline B22 & 2 & 4,830 & 4,185 & $13,359 \%$ & $86,641 \%$ & 2 & 15 & 0,075 & 0,645 \\
\hline B23 & 2 & 4,830 & 4,185 & $13,359 \%$ & $86,641 \%$ & 2 & 15 & 0,075 & 0,645 \\
\hline B24 & 2 & 4,830 & 4,086 & $15,408 \%$ & $84,592 \%$ & 5 & 15 & 0,174 & 0,744 \\
\hline B25 & 2 & 4,830 & 3,994 & $17,318 \%$ & $82,682 \%$ & 8 & 15 & 0,266 & 0,836 \\
\hline B26 & 3 & 10,245 & 9,161 & $10,581 \%$ & $89,419 \%$ & 4 & 15 & 0,214 & 1,084 \\
\hline B27 & 3 & 10,245 & 8,975 & $12,392 \%$ & $87,608 \%$ & 8 & 15 & 0,400 & 1,270 \\
\hline B28 & 5 & 27,075 & 24,787 & $8,450 \%$ & $91,550 \%$ & 10 & 15 & 0,818 & 2,288 \\
\hline
\end{tabular}




\section{8. Índice Remissivo}

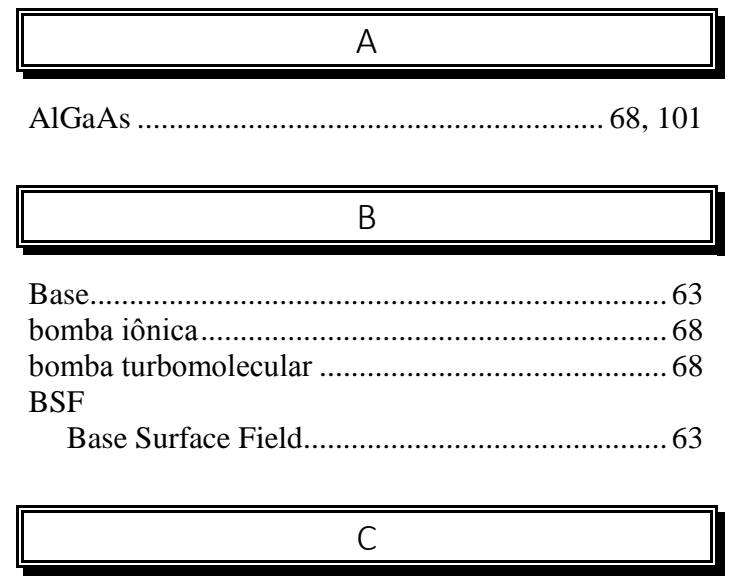

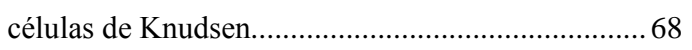
corrente de curto circuito

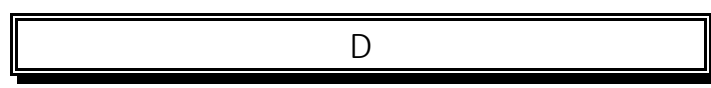

difusão...

63,82

dopagem

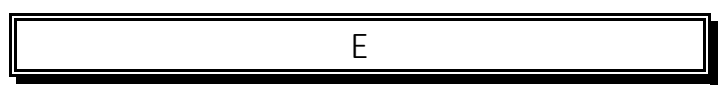

eficiência

$24,25,57,58,59,72,92,108$

Eficiência quântica.

...92

epitaxia............................................... 24, 26

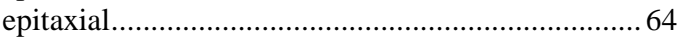

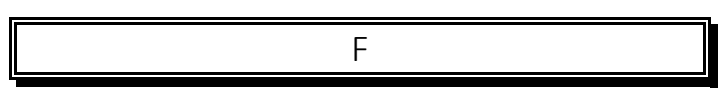

fingers .

$73,74,76,77,100,101,102,104$

fotocélula

58,92

fotocorrente.

63

fotolitografia

... 70

fotorresiste

AZ5214

$70,76,77$

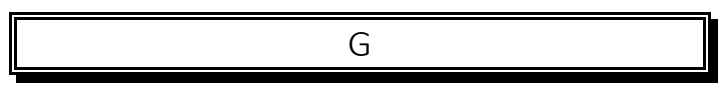

$\mathrm{GaAs}$

$1,24,59,68,97,108$

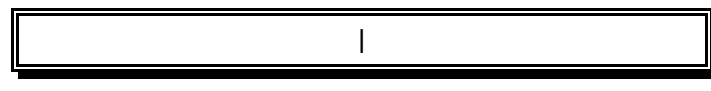

InAs

68

\section{$\mathrm{M}$}

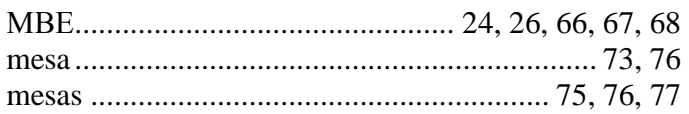

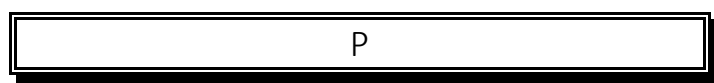

pin ................................................... 26, 33, 112

pn 57,58

portadores .............................................. 63, 64, 101

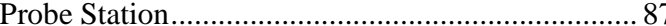

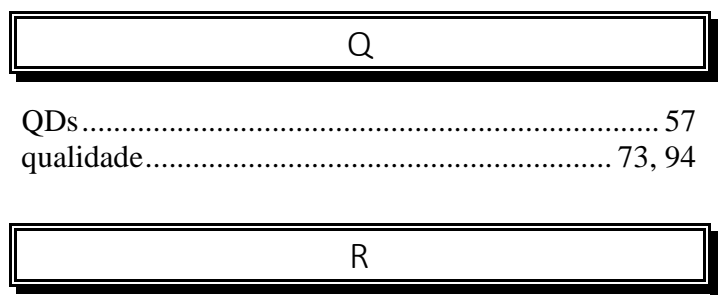

recombinação ..................................... 49, 63, 64, 101

resistividade de contato ........................................... 97

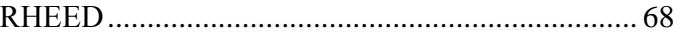

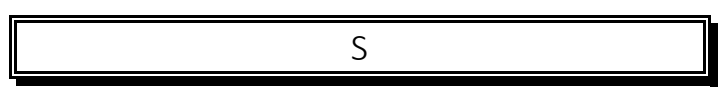

Shockley-Queisser .

$24,57,59$

simulador solar........

$58,76,94,95$

Stranski-Krastanov

\section{$\mathrm{T}$}

TLM

$87,88,89,97,98$ 